\title{
Challenges in Developing K-8 Science Programs Aligned with the Next Generation Science Standards
}

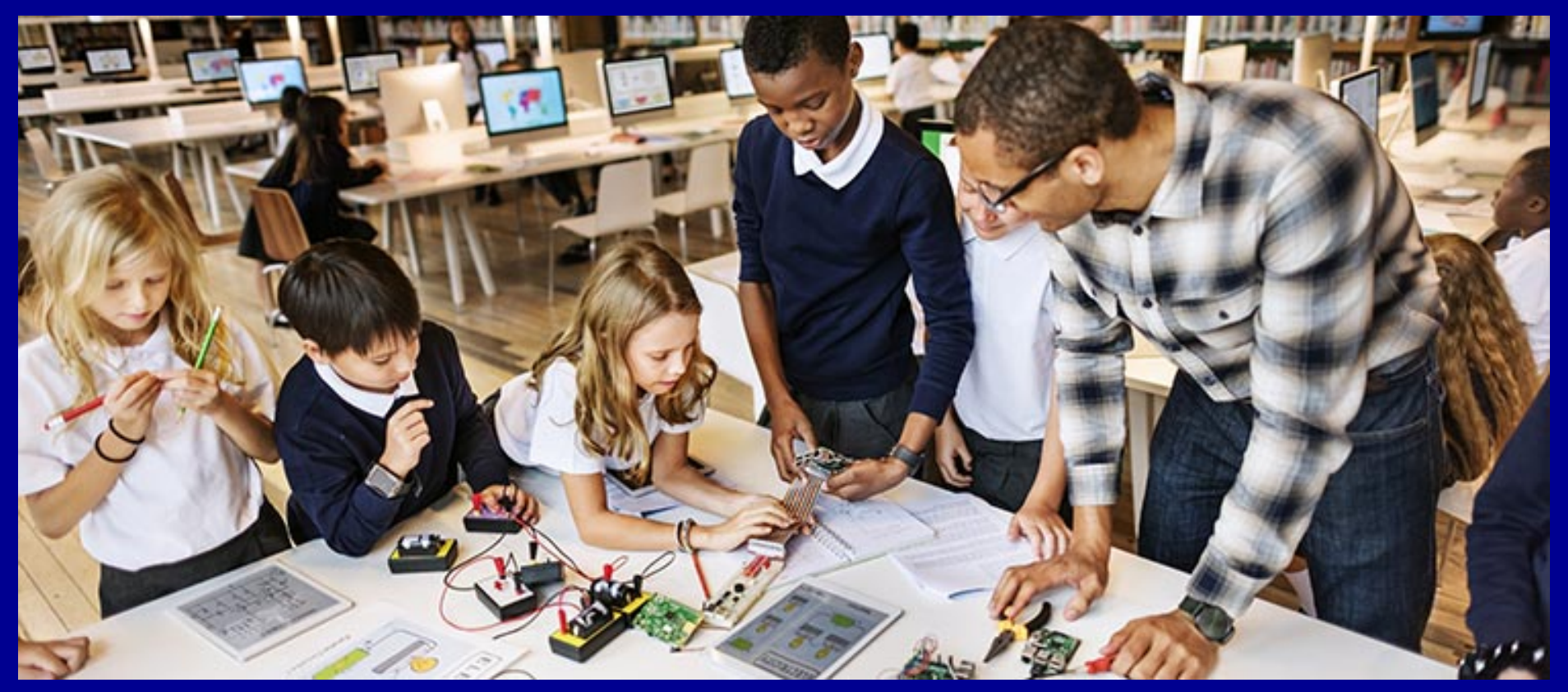

Michael Wysession

Department of Earth and Planetary Sciences

Washington University, St. Louis, MO

Seattle, WA, Oct 24, 2017 


\section{PEEC for NGSS Instructional Materials Design}

\section{Overview of PEEC}

PEEC is an acronym for the Primary Evaluation of Essential Criteria for NGSS Instructional Materials Design.

PEEC takes the compelling vision for science education as described in A Framework for K-12 Science Education and embodied in the Next Generation Science Standards (NGSS) and operationalizes it for two purposes:

1. to help educators determine how well instructional materials under consideration have been designed for the Framework and

NGSS, and

2. to help curriculum developers construct and write science instructional materials that are designed for the Framework and NGSS.

The resource seeks to focus educators and curriculum developers on the critical innovations within the NGSS and dig deeply into materials to (1) evaluate the presence of those innovations and (2) answer the question "How thoroughly are these science instructional materials designed for the NGSS? PEEC can be used by educators to evaluate the NGSS design of textbooks as well as

comprehensive science instructional materials programs designed to include different units, kits, modules, textbooks, textbook series, or web-based instructional materials, including open educational resources. PEEC enables curriculum developers to more easily create and refine instructional materials, and do so knowing that their efforts are focused on the same NGSS innovations that schools, districts, and states will be using to select their instructional materials.

Throughout PEEC, the word "designed" is intentionally used rather than "aligned." The word "designed" was chosen because it reflects the degree to which the materials were consciously planned and organized to support the NGSS. For curriculum developers, this might mean starting from scratch and building new materials, or it might mean starting with existing materials and significantly reworking them. The focus either way is ensuring that the NGSS innovations are a foundational aspect of, and clearly visible within, instructional materials.

Download PEEC for more information. Click here for FAQs about PEEC.

\section{RECENT NEWS}

> July 2017 NGSS NOW Newsletter

> Primary Evaluation of Essential Criteria for NGSS Instructional Materials Design

> June 2017 NGSS NOW Newsletter

> EQulP Peer Review Panel for Science: New Category, New Badge, New Pathway

> NGSS District Implementation Workbook 


\section{Any NGSS-designed Curricular Materials Should Incorporate the "Five NGSS Innovations"}

1. Three-Dimensional Learning 


\section{NRC Framework}

Three

Dimensions:

(1) Disciplinary

Core Ideas (DCls)

(2) Science and

Engineering

Practices (SEPs)

(3) Crosscutting

Concepts (CCCs) 


\section{NRC Framework}

\section{Three}

\section{Dimensions:}

\section{(1) Disciplinary Core Ideas (DCls)}

\section{(2) Science and} Engineering Practices (SEPs)

\section{(3) Crosscutting Concepts (CCCs)}

\section{HS-ESS3-1 Earth and Human Activity}

Students who demonstrate understanding can:

HS-ESS3-1. Construct an explanation based on evidence for how the availability of natural resources, occurrence of natural hazards, and changes in climate have influenced human activity. [Clarification Statement: Examples of key natural resources include access to fresh water (such as rivers, lakes, and groundwater), regions of fertile soils such as river deltas, and high concentrations of minerals and fossil fuels. Examples of natural hazards can be from interior processes (such as volcanic eruptions and earthquakes), surface processes (such as tsunamis, mass wasting and soil erosion), and severe weather (such as hurricanes, floods, and droughts). Examples of the results of changes in climate that can affect populations or drive mass migrations include changes to sea level, regional patterns of temperature and precipitation, and the types of crops and livestock that can be raised.]

\begin{tabular}{|c|c|c|c|}
\hline \multicolumn{2}{|r|}{ PRACTICES } & BIG IDEAS & X-CUTTING CONCEPTS \\
\hline \multicolumn{2}{|c|}{$\begin{array}{l}\text { Constructing Explanations and Designing } \\
\text { Solutions } \\
\text { Constructing explanations and designing solutions in } \\
9-12 \text { builds on K-8 experiences and progresses to } \\
\text { explanations and designs that are supported by } \\
\text { multiple and independent student-generated sources } \\
\text { of evidence consistent with scientific knowledge, } \\
\text { principles, and theories. } \\
\text { - Construct an explanation based on valid and } \\
\text { reliable evidence obtained from a variety of } \\
\text { sources (including students' own investigations, } \\
\text { models, theories, simulations, peer review) and } \\
\text { the assumption that theories and laws that } \\
\text { describe the natural world operate today as they } \\
\text { did in the past and will continue to do so in the } \\
\text { future. }\end{array}$} & $\begin{array}{l}\text { ESS3.A: Natural Resources } \\
\text { - Resource availability has guided the } \\
\text { development of human society. } \\
\text { ESS3.B: Natural Hazards } \\
\text { - Natural hazards and other geologic events have } \\
\text { shaped the course of human history; [they] have } \\
\text { significantly altered the sizes of human } \\
\text { populations and have driven human migrations. }\end{array}$ & $\begin{array}{l}\text { Cause and Effect } \\
\text { Empirical evidence is required to differentiate } \\
\text { between cause and correlation and make claims } \\
\text { about specific causes and effects. } \\
\text { Connections to Engineering, Technology, and } \\
\text { Applications of Science } \\
\text { Influence of Science, Engineering, and } \\
\text { Technology on Society and the Natural World } \\
\text { Modern civilization depends on major } \\
\text { technological systems. }\end{array}$ \\
\hline \multicolumn{4}{|c|}{ Connections to other DCls in this grade-band: N/A } \\
\hline \multicolumn{4}{|c|}{$\begin{array}{l}\text { Articulation of DCls across grade-bands: } \\
\text { MS.LS2.A; MS.LS4.D; MS.ESS2.A; MS.ESS3.A; MS.ESS3.B }\end{array}$} \\
\hline \multicolumn{4}{|c|}{ 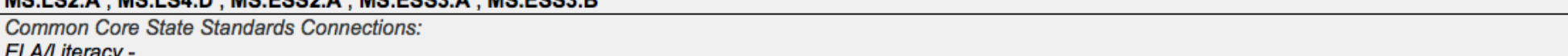 } \\
\hline $\begin{array}{l}\text { ELALiteracy- } \\
\text { RST.11-12.1 }\end{array}$ & \multicolumn{3}{|c|}{$\begin{array}{l}\text { Cite specific textual evidence to support analysis of science and technical texts, attending to important distinctions the author makes and to any gaps or } \\
\text { ins }\end{array}$} \\
\hline & & Write informative/explanatory texts, including the narration of historical events, scientific procedures/ experiments, or technical processes. (HS-ESS3-1) \\
\hline \multirow{2}{*}{ HSN.Q.A.1 } & \multirow{2}{*}{\multicolumn{3}{|c|}{$\begin{array}{l}\text { Use units as a way to understand problems and to guide the solution of multi-step problems; choose and interpret units consistently in formulas; choose } \\
\text { and interpret the scale and the origin in graphs and data displays. (HS-ESS3-1) } \\
\text { Define anorooriate quantities for the puroose of descriotive modelina. (HS-ESS3-1) }\end{array}$}} \\
\hline & & & \\
\hline HSN.Q.A.3 & \multicolumn{3}{|c|}{ Choose a level of accuracy appropriate to limitations on measurement when reporting quantities. (HS-ESS3-1) } \\
\hline
\end{tabular}




\section{NRC Framework}

\section{Three}

\section{Dimensions:}

\section{(1) Disciplinary Core Ideas (DCls)}

\section{(2) Science and} Engineering Practices (SEPs)

\section{(3) Crosscutting Concepts (CCCs)}

\section{HS-ESS3-1 Earth and Human Activity}

Students who demonstrate understandina can:

\section{Performance Expectation}

HS-ESS3-1. Construct an explanation based on evidence for how the availability of natural resources, occurrence of natura hazards, and changes in climate have influenced human activity. [Clarification Statement: Examples of key natural resources include access to iresh water (such as rivers, lakes, and grounawater), regions of tertile solis such as river deltas, and high concentrations of minerals and fossil fuels. Examples of natural hazards can be from interior processes (such as volcanic eruptions and earthquakes), surface processes (such as tsunamis, mass wasting and soil erosion), and severe weather (such as hurricanes, floods, and droughts). Examples of the results of changes in climate that can affect populations or drive mass migrations include changes to sea level, regional patterns of temperature and precipitation, and the types of crops and livestock that can be raised.]

\begin{tabular}{|c|c|c|c|}
\hline \multicolumn{2}{|r|}{ PRACTICES } & BIG IDEAS & X-CUTTING CONCEPTS \\
\hline \multicolumn{2}{|c|}{$\begin{array}{l}\text { Constructing Explanations and Designing } \\
\text { Solutions } \\
\text { Constructing explanations and designing solutions in } \\
9-12 \text { builds on K-8 experiences and progresses to } \\
\text { explanations and designs that are supported by } \\
\text { multiple and independent student-generated sources } \\
\text { of evidence consistent with scientific knowledge, } \\
\text { principles, and theories. } \\
\text { - Construct an explanation based on valid and } \\
\text { reliable evidence obtained from a variety of } \\
\text { sources (including students' own investigations, } \\
\text { models, theories, simulations, peer review) and } \\
\text { the assumption that theories and laws that } \\
\text { describe the natural world operate today as they } \\
\text { did in the past and will continue to do so in the } \\
\text { future. }\end{array}$} & $\begin{array}{l}\text { ESS3.A: Natural Resources } \\
\text { - Resource availability has guided the } \\
\text { development of human society. } \\
\text { ESS3.B: Natural Hazards } \\
\text { - Natural hazards and other geologic events have } \\
\text { shaped the course of human history; [they] have } \\
\text { significantly altered the sizes of human } \\
\text { populations and have driven human migrations. }\end{array}$ & $\begin{array}{l}\text { Cause and Effect } \\
\text { Empirical evidence is required to differentiate } \\
\text { between cause and correlation and make claims } \\
\text { about specific causes and effects. } \\
\text { Connections to Engineering, Technology, and } \\
\text { Applications of Science } \\
\text { Influence of Science, Engineering, and } \\
\text { Technology on Society and the Natural World } \\
\text { Modern civilization depends on major } \\
\text { technological systems. }\end{array}$ \\
\hline \multicolumn{4}{|c|}{ Connections to other DCls in this grade-band: N/A } \\
\hline \multicolumn{4}{|c|}{$\begin{array}{l}\text { Articulation of DCls across grade-bands: } \\
\text { MS.LS2.A ; MS.LS4.D; MS.ESS2.A ; MS.ESS3.A ; MS.ESS3.B }\end{array}$} \\
\hline \multicolumn{4}{|c|}{$\begin{array}{l}\text { MS.LS2.A; MS.LS4.D; MS.ESS2.A; MS.ESS3.A ; MS.ESS3.B } \\
\text { Common Core State Standards Connections: }\end{array}$} \\
\hline RST.11-12.1 & \multicolumn{3}{|c|}{$\begin{array}{l}\text { Cite specific textual evidence to support analysis of science and technical texts, attending to important distinctions the author makes and to any gaps or } \\
\text { inconsistencies in the account. (HS-ESS3-1) }\end{array}$} \\
\hline \multicolumn{4}{|c|}{ 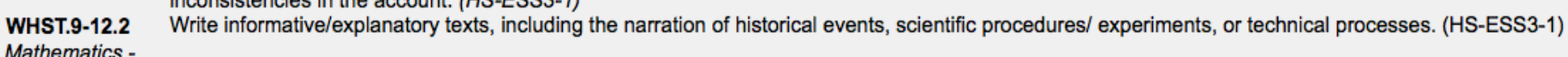 } \\
\hline & \multicolumn{3}{|c|}{ Reason abstractly and quantitatively. (HS-ESS3-1) } \\
\hline HSN.Q.A.1 & \multicolumn{3}{|c|}{$\begin{array}{l}\text { Use units as a way to understand problems and to guide the solution of multi-step problems; choose and interpret units consistently in formulas; choose } \\
\text { and interpret the scale and the origin in graphs and data displays. (HS-ESS3-1) }\end{array}$} \\
\hline HSN.Q.A.2 & \multicolumn{3}{|c|}{ Define appropriate quantities for the purpose of descriptive modeling. (HS-ESS3-1) } \\
\hline HSN.Q.A.3 & \multicolumn{3}{|c|}{ Choose a level of accuracy appropriate to limitations on measurement when reporting quantities. (HS-ESS3-1) } \\
\hline
\end{tabular}




\section{NRC Framework}

\section{Three}

\section{Dimensions:}

\section{(1) Disciplinary Core Ideas (DCls)}

\section{(2) Science and} Engineering Practices (SEPs)

\section{(3) Crosscutting Concepts (CCCs)}

\section{HS-ESS3-1 Earth and Human Activity}

Students who demonstrate understandina can:

\section{Performance Expectation}

HS-ESS3-1. Construct an explanation based on evidence for how the availability of natural resources, occurrence of natura hazards, and changes in climate have influenced human activity. [Clarification Statement: Examples of key natural resources include access to tresh water (sucn as rivers, lakes, and grounawater), regions of tertile solls such as river deltas, and high concentrations of minerals and fossil fuels. Examples of natural hazards can be from interior processes (such as volcanic eruptions and earthquakes), surface processes (such as tsunamis, mass wasting and soil erosion), and severe weather (such as hurricanes, floods, and droughts). Examples of the results of changes in climate that can affect populations or drive mass migrations include changes to sea level, regional patterns of temperature and precipitation, and the types of crops and livestock that can be raised.]

\begin{tabular}{|c|c|c|c|}
\hline & PRACTICES & BIG IDEAS & X-CUTTING CONCEPTS \\
\hline \multicolumn{2}{|c|}{$\begin{array}{l}\text { Constructing Explanations and Designing } \\
\text { Solutions } \\
\text { Constructing explanations and designing solutions in } \\
9-12 \text { builds on K-8 experiences and progresses to } \\
\text { explanations and designs that are supported by } \\
\text { multiple and independent student-generated sources } \\
\text { of evidence consistent with scientific knowledge, } \\
\text { principles, and theories. } \\
\text { - Construct an explanation based on valid and } \\
\text { reliable evidence obtained from a variety of } \\
\text { sources (including students' own investigations, } \\
\text { models, theories, simulations, peer review) and } \\
\text { the assumption that theories and laws that } \\
\text { describe the natural world operate today as they } \\
\text { did in the past and will continue to do so in the } \\
\text { future. }\end{array}$} & $\begin{array}{l}\text { ESS3.A: Natural Resources } \\
\text { - Resource availability has guided the } \\
\text { development of human society. } \\
\text { ESS3.B: Natural Hazards } \\
\text { - Natural hazards and other geologic events have } \\
\text { shaped the course of human history; [they] have } \\
\text { significantly altered the sizes of human } \\
\text { populations and have driven human migrations. }\end{array}$ & $\begin{array}{l}\text { Cause and Effect } \\
\text { Empirical evidence is required to differentiate } \\
\text { between cause and correlation and make claims } \\
\text { about specific causes and effects. } \\
\text { Connections to Engineering, Technology, and } \\
\text { Applications of Science } \\
\text { Influence of Science, Engineering, and } \\
\text { Technology on Society and the Natural World } \\
\text { Modern civilization depends on major } \\
\text { technological systems. }\end{array}$ \\
\hline \multicolumn{4}{|c|}{ Connections to other DCls in this grade-band: N/A } \\
\hline \multicolumn{4}{|c|}{$\begin{array}{l}\text { Articulation of DCls across grade-bands: } \\
\text { MS.LS2.A ; MS.LS4.D ; MS.ESS2.A ; MS.ESS3.A ; MS.ESS3.B }\end{array}$} \\
\hline \multicolumn{4}{|c|}{$\begin{array}{l}\text { Common Core State Standards Connections: } \\
\text { ELA/Literacy. }\end{array}$} \\
\hline $\begin{array}{l}\text { ELALliteracy - } \\
\text { RST.11-12.1 }\end{array}$ & \multicolumn{3}{|c|}{$\begin{array}{l}\text { Cite specific textual evidence to support analysis of science and technical texts, attending to important distinctions the author makes and to any gaps or } \\
\text { inconsistencies in the account. (HS-ESS3-1) }\end{array}$} \\
\hline $\begin{array}{l}\text { WHST.9-12.2 } \\
\text { Mathematics - }\end{array}$ & \multicolumn{3}{|c|}{ Write informative/explanatory texts, including the narration of historical events, scientific procedures/ experiments, or technical processes. (HS-ESS3-1) } \\
\hline & \multicolumn{3}{|c|}{ Reason abstractly and quantitatively. (HS-ESS3-1) } \\
\hline HSN.Q.A.1 & \multicolumn{3}{|c|}{$\begin{array}{l}\text { Use units as a way to understand problems and to guide the solution of multi-step problems; choose and interpret units consistently in formulas; choose } \\
\text { and interpret the scale and the origin in graphs and data displays. (HS-ESS3-1) }\end{array}$} \\
\hline HSN.Q.A.2 & \multicolumn{3}{|c|}{ Define appropriate quantities for the purpose of descriptive modeling. (HS-ESS3-1) } \\
\hline HSN.Q.A.3 & \multicolumn{3}{|c|}{ Choose a level of accuracy appropriate to limitations on measurement when reporting quantities. (HS-ESS3-1) } \\
\hline
\end{tabular}




\section{NRC Framework}

\section{Three}

\section{Dimensions:}

\section{(1) Disciplinary Core Ideas (DCls)}

\section{(2) Science and} Engineering Practices (SEPs)

\section{(3) Crosscutting Concepts (CCCs)}

\section{HS-ESS3-1 Earth and Human Activity}

Students who demonstrate understandina can:

\section{Performance Expectation}

HS-ESS3-1. Construct an explanation based on evidence for how the availability of natural resources, occurrence of natura hazards, and changes in climate have influenced human activity. [Clarification Statement: Examples of key natural resources include access to tresh water (sucn as rivers, lakes, and grounawater), regions of tertile solls such as river deltas, and high concentrations of minerals and fossil fuels. Examples of natural hazards can be from interior processes (such as volcanic eruptions and earthquakes), surface processes (such as tsunamis, mass wasting and soil erosion), and severe weather (such as hurricanes, floods, and droughts). Examples of the results of changes in climate that can affect populations or drive mass migrations include changes to sea level, regional patterns of temperature and precipitation, and the types of crops and livestock that can be raised.]

\begin{tabular}{|c|c|c|}
\hline PRACTICES & BIG IDEAS & X-CUTTING CONCEPTS \\
\hline \multirow{2}{*}{$\begin{array}{l}\text { Constructing Explanations and Designing } \\
\text { Solutions } \\
\text { Constructing explanations and designing solutions in } \\
9-12 \text { builds on K- } 8 \text { experiences and progresses to } \\
\text { explanations and designs that are supported by } \\
\text { multiple and independent student-generated sources } \\
\text { of evidence consistent with scientific knowledge, }\end{array}$} & \multirow{4}{*}{$\begin{array}{l}\text { - Resource availability has guided the } \\
\text { develooment of human societv. } \\
\text { ESS3.B: Natural Hazards } \\
\text { shaped the course of human history; [they] have } \\
\text { significantly altered the sizes of human } \\
\text { populations and have driven human migrations. }\end{array}$} & $\begin{array}{l}\text { Cause and Effect } \\
\text { Empirical evidence is required to differentiate } \\
\text { between cause and correlation and make claims } \\
\text { about specific causes and effects. }\end{array}$ \\
\hline & & Connections to Enqineoring Technology and \\
\hline \multirow{2}{*}{$\begin{array}{l}\text { - Construct an explanation based on valid and } \\
\text { reliable evidence obtained from a variety of } \\
\text { sources (including students' own investigations, } \\
\text { models, theories, simulations, peer review) and } \\
\text { the assumption that theories and laws that } \\
\text { describe the natural world operate today as they } \\
\text { did in the past and will continue to do so in the } \\
\text { future. }\end{array}$} & & $\begin{array}{l}\text { Applications of Science } \\
\text { Influence of Science, Engineering, and } \\
\text { Technology on Society and the Natural World }\end{array}$ \\
\hline & & 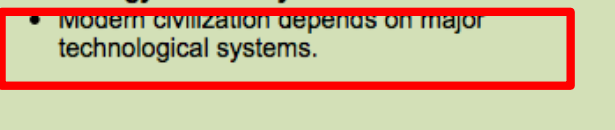 \\
\hline
\end{tabular}

Connections to other DCls in this grade-band: N/A

Articulation of $D C l s$ across grade-bands:

MS.LS2.A ; MS.LS4.D ; MS.ESS2.A ; MS.ESS3.A ; MS.ESS3.B

Common Core State Standards Connections:

ELA/Literacy -

RST11-121

Cite specific textual evidence to support analysis of science and technical texts, attending to important distinctions the author makes and to any gaps or inconsistencies in the account. (HS-ESS3-1)

WHST.9-12.2 Write informative/explanatory texts, including the narration of historical events, scientific procedures/ experiments, or technical processes. (HS-ESS3-1)

Mathematics -

MP.2

Reason abstractly and quantitatively. (HS-ESS3-1)

Use units as a way to understand problems and to guide the solution of multi-step problems; choose and interpret units consistently in formulas; choose and interpret the scale and the origin in graphs and data displays. (HS-ESS3-1)

HSN.Q.A.2 Define appropriate quantities for the purpose of descriptive modeling. (HS-ESS3-1)

HSN.Q.A.3

Choose a level of accuracy appropriate to limitations on measurement when reporting quantities. (HS-ESS3-1) 


\section{Any NGSS-designed Curricular Materials Should Incorporate the "Five NGSS Innovations"}

1. Three-Dimensional Learning

2. Building K-12 Progressions 


\section{Example of K-12} Progressions:

\section{Developing} and Using Models

\begin{tabular}{|c|c|c|c|c|}
\hline $\begin{array}{c}\text { Science and } \\
\text { Engineering Practices }\end{array}$ & K-2 Condensed Practices & 3-5 Condensed Practices & 6-8 Condensed Practices & 9-12 Condensed Practices \\
\hline \multirow{2}{*}{$\begin{array}{l}\text { Developing and Using } \\
\text { Models } \\
\\
\text { A practice of both science } \\
\text { and engineering is to use } \\
\text { and construct models as } \\
\text { helpfoul tools for representing } \\
\text { ideas and explanations. } \\
\text { These tools include } \\
\text { diagrams, drawings, physical } \\
\text { replicas, mathematical } \\
\text { representations, analogies, } \\
\text { and computer simulations. }\end{array}$} & $\begin{array}{l}\text { Modeling in K-2 builds on prior } \\
\text { experiences and progresses to } \\
\text { include using and developing } \\
\text { models (i.e., diagram, drawing, } \\
\text { physical replica, diorama, } \\
\text { dramatization, or storyboard) that } \\
\text { represent concrete events or } \\
\text { design solutions. }\end{array}$ & $\begin{array}{l}\text { Modeling in 3-5 builds on } \mathrm{K}-2 \\
\text { experiences and progresses to } \\
\text { building and revising simple models } \\
\text { and using models to represent } \\
\text { events and design solutions. }\end{array}$ & $\begin{array}{l}\text { Modeling in } 6-8 \text { builds on } \mathrm{K}-5 \\
\text { experiences and progresses to } \\
\text { developing, using, and revising } \\
\text { models to describe, test, and predict } \\
\text { more abstract phenomena and } \\
\text { design systems. }\end{array}$ & $\begin{array}{l}\text { Modeling in } 9-12 \text { builds on } \mathrm{K}-8 \\
\text { experiences and progresses to using, } \\
\text { synthesizing, and developing models } \\
\text { to predict and show relationships } \\
\text { among variables between systems } \\
\text { and their components in the natural } \\
\text { and designed world(s). }\end{array}$ \\
\hline & $\begin{array}{l}\text { Distinguish between a model } \\
\text { and the actual object, process, } \\
\text { and/or events the model } \\
\text { represents. } \\
\text { Compare models to identify } \\
\text { common features and } \\
\text { differences. }\end{array}$ & - Identify limitations of models. & $\begin{array}{l}\text { Evaluate limitations of a model for } \\
\text { a proposed object or tool. }\end{array}$ & $\begin{array}{l}\text { Evaluate merits and limitations of } \\
\text { two different models of the same } \\
\text { proposed tool, process, mechanism, } \\
\text { or system in order to select or } \\
\text { revise a model that best fits the } \\
\text { evidence or design criteria. } \\
\text { Design a test of a model to } \\
\text { ascertain its reliability. }\end{array}$ \\
\hline \multirow[t]{2}{*}{$\begin{array}{l}\text { Modeling tools are used to } \\
\text { develop questions, } \\
\text { predictions and explanations; } \\
\text { analyze and identify flaws in } \\
\text { systems; and communicate } \\
\text { ideas. Models are used to } \\
\text { build and revise scientific } \\
\text { explanations and proposed } \\
\text { engineered systems. } \\
\text { Measurements and } \\
\text { observations are used to } \\
\text { revise models and designs. }\end{array}$} & $\begin{array}{l}\text { Develop and/or use a model to } \\
\text { represent amounts, } \\
\text { relationships, relative scales } \\
\text { (bigger, smaller), and/or } \\
\text { patterns in the natural and } \\
\text { designed world(s). }\end{array}$ & $\begin{array}{l}\text { - Collaboratively develop and/or } \\
\text { revise a model based on evidence } \\
\text { that shows the relationships } \\
\text { among variables for frequent and } \\
\text { regular occurring events. } \\
\text { Develop a model using an } \\
\text { analogy, example, or abstract } \\
\text { representation to describe a } \\
\text { scientific principle or design } \\
\text { solution. } \\
\text { Develop and/or use models to } \\
\text { describe and/or predict } \\
\text { phenomena. }\end{array}$ & $\begin{array}{l}\text { - Develop or modify a model-based } \\
\text { on evidence - to match what } \\
\text { happens if a variable or } \\
\text { component of a system is } \\
\text { changed. } \\
\text { - Use and/or develop a model of } \\
\text { simple systems with uncertain and } \\
\text { less predictable factors. } \\
\text { - Develop and/or revise a model to } \\
\text { show the relationships among } \\
\text { variables, including those that are } \\
\text { not observable but predict } \\
\text { observable phenomena. } \\
\text { Develop and/or use a model to } \\
\text { predict and/or describe } \\
\text { phenomena. } \\
\text { Develop a model to describe } \\
\text { unobservable mechanisms. }\end{array}$ & $\begin{array}{l}\text { - Develop, revise, and/or use a model } \\
\text { based on evidence to illustrate } \\
\text { and/or predict the relationships } \\
\text { between systems or between } \\
\text { components of a system. } \\
\text { Develop and/or use multiple types } \\
\text { of models to provide mechanistic } \\
\text { accounts and/or predict } \\
\text { phenomena, and move flexibly } \\
\text { between model types based on } \\
\text { merits and limitations. }\end{array}$ \\
\hline & $\begin{array}{l}\text { Develop a simple model based } \\
\text { on evidence to represent a } \\
\text { proposed object or tool. }\end{array}$ & $\begin{array}{l}\text { Develop a diagram or simple } \\
\text { physical prototype to convey a } \\
\text { proposed object, tool, or process. } \\
\text { Use a model to test cause and } \\
\text { effect relationships or interactions } \\
\text { concerning the functioning of a } \\
\text { natural or designed system. }\end{array}$ & $\begin{array}{l}\text { Develop and/or use a model to } \\
\text { generate data to test ideas about } \\
\text { phenomena in natural or designed } \\
\text { systems, including those } \\
\text { representing inputs and outputs, } \\
\text { and those at unobservable scales. }\end{array}$ & $\begin{array}{l}\text { Develop a complex model that } \\
\text { allows for manipulation and testing } \\
\text { of a proposed process or system. } \\
\text { Develop and/or use a model } \\
\text { (including mathematical and } \\
\text { computational) to generate data to } \\
\text { support explanations, predict } \\
\text { phenomena, analyze systems, } \\
\text { and/or solve problems. }\end{array}$ \\
\hline
\end{tabular}




\section{Example of K-12} Progressions:

\section{Developing} and Using Models

\begin{tabular}{|c|c|c|c|c|}
\hline $\begin{array}{c}\text { Science and } \\
\text { Engineering Practices }\end{array}$ & K-2 Condensed Practices & 3-5 Condensed Practices & 6-8 Condensed Practices & 9-12 Condensed Practices \\
\hline \multirow{4}{*}{$\begin{array}{l}\text { Developing and Using } \\
\text { Models } \\
\text { A practice of both science } \\
\text { and engineering is to use } \\
\text { and construct models as } \\
\text { helpful tools for representing } \\
\text { ideas and explanations. } \\
\text { These tools include } \\
\text { diagrams, drawings, physical } \\
\text { replicas, mathematical } \\
\text { representations, analogies, } \\
\text { and computer simulations. } \\
\\
\text { Modeling tools are used to } \\
\text { develop questions, } \\
\text { predictions and explanations; } \\
\text { analyze and identify flaws in } \\
\text { systems; and communicate } \\
\text { ideas. Models are used to } \\
\text { build and revise scientific } \\
\text { explanations and proposed } \\
\text { engineered systems. } \\
\text { Measurements and } \\
\text { observations are used to } \\
\text { revise models and designs. }\end{array}$} & $\begin{array}{l}\text { Modeling in K-2 builds on priar } \\
\text { experiences and proaresses to } \\
\text { models (i.e., diagram, drawirn } \\
\text { physical replica, diorama, } \\
\text { dramatization, or storyboard) that } \\
\text { represent concrete events or } \\
\text { design solutions. }\end{array}$ & $\begin{array}{l}\text { Modeling in 3-5 builds on } \mathrm{K}-2 \\
\text { experiences and progresses to } \\
\text { building and revising simple models } \\
\text { and using models to represent } \\
\text { events and design solutions. }\end{array}$ & $\begin{array}{l}\text { Modeling in } 6-8 \text { builds on } \mathrm{K}-5 \\
\text { experiences and progresses to } \\
\text { developing, using, and revising } \\
\text { models to describe, test, and predict } \\
\text { more abstract phenomena and } \\
\text { design systems. }\end{array}$ & $\begin{array}{l}\text { Modeling in 9-12 builds on K-8 } \\
\text { experiences and progresses to using, } \\
\text { synthesizing, and developing models } \\
\text { to predict and show relationships } \\
\text { among variables between systems } \\
\text { and their components in the natural } \\
\text { and designed world(s). }\end{array}$ \\
\hline & $\begin{array}{l}\text { Distinguish between a model } \\
\text { and the actual object, process, } \\
\text { and/or events the model } \\
\text { represents. } \\
\text { Compare models to identify } \\
\text { common features and } \\
\text { differences. }\end{array}$ & - Identify limitations of models. & $\begin{array}{l}\text { - Evaluate limitations of a model for } \\
\text { a proposed object or tool. }\end{array}$ & $\begin{array}{l}\text { - Evaluate merits and limitations of } \\
\text { two different models of the same } \\
\text { proposed tool, process, mechanism, } \\
\text { or system in order to select or } \\
\text { revise a model that best fits the } \\
\text { evidence or design criteria. } \\
\text { - Design a test of a model to } \\
\text { ascertain its reliability. }\end{array}$ \\
\hline & $\begin{array}{l}\text { Develop and/or use a model to } \\
\text { represent amounts, } \\
\text { relationships, relative scales } \\
\text { (bigger, smaller), and/or } \\
\text { patterns in the natural and } \\
\text { designed world(s). }\end{array}$ & $\begin{array}{l}\text { - Collaboratively develop and/or } \\
\text { revise a model based on evidence } \\
\text { that shows the relationships } \\
\text { among variables for frequent and } \\
\text { regular occurring events. } \\
\text { Develop a model using an } \\
\text { analogy, example, or abstract } \\
\text { representation to describe a } \\
\text { scientific principle or design } \\
\text { solution. } \\
\text { Develop and/or use models to } \\
\text { describe and/or predict } \\
\text { phenomena. }\end{array}$ & $\begin{array}{l}\text { - Develop or modify a model-based } \\
\text { on evidence - to match what } \\
\text { happens if a variable or } \\
\text { component of a system is } \\
\text { changed. } \\
\text { - Use and/or develop a model of } \\
\text { simple systems with uncertain and } \\
\text { less predictable factors. } \\
\text { - Develop and/or revise a model to } \\
\text { show the relationships among } \\
\text { variables, including those that are } \\
\text { not observable but predict } \\
\text { observable phenomena. } \\
\text { - Develop and/or use a model to } \\
\text { predict and/or describe } \\
\text { phenomena. } \\
\text { Develop a model to describe } \\
\text { unobservable mechanisms. }\end{array}$ & $\begin{array}{l}\text { Develop, revise, and/or use a model } \\
\text { based on evidence to illustrate } \\
\text { and/or predict the relationships } \\
\text { between systems or between } \\
\text { components of a system. } \\
\text { Develop and/or use multiple types } \\
\text { of models to provide mechanistic } \\
\text { accounts and/or predict } \\
\text { phenomena, and move flexibly } \\
\text { between model types based on } \\
\text { merits and limitations. }\end{array}$ \\
\hline & $\begin{array}{l}\text { Develop a simple model based } \\
\text { on evidence to represent a } \\
\text { proposed object or tool. }\end{array}$ & $\begin{array}{l}\text { Develop a diagram or simple } \\
\text { physical prototype to convey a } \\
\text { proposed object, tool, or process. } \\
\text { Use a model to test cause and } \\
\text { effect relationships or interactions } \\
\text { concerning the functioning of a } \\
\text { natural or designed system. }\end{array}$ & $\begin{array}{l}\text { - Develop and/or use a model to } \\
\text { generate data to test ideas about } \\
\text { phenomena in natural or designed } \\
\text { systems, including those } \\
\text { representing inputs and outputs, } \\
\text { and those at unobservable scales. }\end{array}$ & $\begin{array}{l}\text { - Develop a complex model that } \\
\text { allows for manipulation and testing } \\
\text { of a proposed process or system. } \\
\text { - Develop and/or use a model } \\
\text { (including mathematical and } \\
\text { computational) to generate data to } \\
\text { support explanations, predict } \\
\text { phenomena, analyze systems, } \\
\text { and/or solve problems. }\end{array}$ \\
\hline
\end{tabular}




\section{Example of K-12} Progressions:

\section{Developing} and Using Models

\begin{tabular}{|c|c|c|c|c|}
\hline $\begin{array}{c}\text { Science and } \\
\text { Engineering Practices }\end{array}$ & K-2 Condensed Practices & 3-5 Condensed Practices & 6-8 Condensed Practices & 9-12 Condensed Practices \\
\hline \multirow{2}{*}{$\begin{array}{l}\text { Developing and Using } \\
\text { Models } \\
\\
\text { A practice of both science } \\
\text { and engineering is to use } \\
\text { and construct models as } \\
\text { helpful tools for representing } \\
\text { ideas and explanations. } \\
\text { These tools include } \\
\text { diagrams, drawings, physical } \\
\text { replicas, mathematical } \\
\text { representations, analogies, } \\
\text { and computer simulations. }\end{array}$} & $\begin{array}{l}\text { Modeling in } \mathrm{K}-2 \text { builds on prior } \\
\text { experiences and proaresses to } \\
\text { models (i.e.e, diagram, drawing } \\
\text { physical replica, diorama, } \\
\text { dramatization, or storyboard) that } \\
\text { represent concrete events or } \\
\text { design solutions. }\end{array}$ & $\begin{array}{l}\text { Modeling in } 3-5 \text { builds on } \mathrm{K}-2 \\
\text { experiences and progresses to } \\
\text { and using models to represer } \\
\text { events and design solutions. }\end{array}$ & $\begin{array}{l}\text { Modeling in 6-8 builds on K-5 } \\
\text { experiences and progresses to } \\
\text { developing, using, and revising } \\
\text { models to describe, test, and predict } \\
\text { more abstract phenomena and } \\
\text { design systems. }\end{array}$ & $\begin{array}{l}\text { Modeling in 9-12 builds on K-8 } \\
\text { experiences and progresses to using, } \\
\text { synthesizing, and developing models } \\
\text { to predict and show relationships } \\
\text { among variables between systems } \\
\text { and their components in the natural } \\
\text { and designed world(s). }\end{array}$ \\
\hline & $\begin{array}{l}\text { Distinguish between a model } \\
\text { and the actual object, process, } \\
\text { and/or events the model } \\
\text { represents. } \\
\text {. Compare models to identify } \\
\text { common features and } \\
\text { differences. }\end{array}$ & - Identify limitations of models. & $\begin{array}{l}\text { Evaluate limitations of a model for } \\
\text { a proposed object or tool. }\end{array}$ & $\begin{array}{l}\text { - Evaluate merits and limitations of } \\
\text { two different models of the same } \\
\text { proposed tool, process, mechanism, } \\
\text { or system in order to select or } \\
\text { revise a model that best fits the } \\
\text { evidence or design criteria. } \\
\text { - Design a test of a model to } \\
\text { ascertain its reliability. }\end{array}$ \\
\hline \multirow[t]{2}{*}{$\begin{array}{l}\text { Modeling tools are used to } \\
\text { develop questions, } \\
\text { predictions and explanations; } \\
\text { analyze and identify flaws in } \\
\text { systems; and communicate } \\
\text { ideas. Models are used to } \\
\text { build and revise scientific } \\
\text { explanations and proposed } \\
\text { engineered systems. } \\
\text { Measurements and } \\
\text { observations are used to } \\
\text { revise models and designs. }\end{array}$} & $\begin{array}{l}\text { Develop and/or use a model to } \\
\text { represent amounts, } \\
\text { relationships, relative scales } \\
\text { (bigger, smaller), and/or } \\
\text { patterns in the natural and } \\
\text { designed world(s). }\end{array}$ & $\begin{array}{l}\text { - Collaboratively develop and/or } \\
\text { revise a model based on evidence } \\
\text { that shows the relationships } \\
\text { among variables for frequent and } \\
\text { regular occurring events. } \\
\text { - Develop a model using an } \\
\text { analogy, example, or abstract } \\
\text { representation to describe a } \\
\text { scientific principle or design } \\
\text { solution. } \\
\text { Develop and/or use models to } \\
\text { describe and/or predict } \\
\text { phenomena. }\end{array}$ & $\begin{array}{l}\text { - Develop or modify a model-based } \\
\text { on evidence - to match what } \\
\text { happens if a variable or } \\
\text { component of a system is } \\
\text { changed. } \\
\text { - Use and/or develop a model of } \\
\text { simple systems with uncertain and } \\
\text { less predictable factors. } \\
\text { - Develop and/or revise a model to } \\
\text { show the relationships among } \\
\text { variables, including those that are } \\
\text { not observable but predict } \\
\text { observable phenomena. } \\
\text { Develop and/or use a model to } \\
\text { predict and//or describe } \\
\text { phenomena. } \\
\text { Develop a model to describe } \\
\text { unobservable mechanisms. }\end{array}$ & $\begin{array}{l}\text { - Develop, revise, and/or use a model } \\
\text { based on evidence te illustrate } \\
\text { and//or predict the relationships } \\
\text { between systems or between } \\
\text { components of a system. } \\
\text { - Develop and/or use multiple types } \\
\text { of models to provide mechanistic } \\
\text { accounts and/or predict } \\
\text { phenomena, and move flexibly } \\
\text { between model types based on } \\
\text { merits and limitations. }\end{array}$ \\
\hline & $\begin{array}{l}\text { Develop a simple model based } \\
\text { on evidence to represent a } \\
\text { proposed object or tool. }\end{array}$ & $\begin{array}{l}\text { Develop a diagram or simple } \\
\text { physical prototype to convey a } \\
\text { proposed object, tool, or process. } \\
\text { Use a model to test cause and } \\
\text { effect relationships or interactions } \\
\text { concerning the functioning of a } \\
\text { natural or designed system. }\end{array}$ & $\begin{array}{l}\text { Develop and/or use a model to } \\
\text { generate data to test ideas about } \\
\text { phenomena in natural or designed } \\
\text { systems, including those } \\
\text { representing inputs and outputs, } \\
\text { and those at unobservable scales. }\end{array}$ & $\begin{array}{l}\text { - Develop a complex model that } \\
\text { allows for manipulation and testing } \\
\text { of a proposed process or system. } \\
\text { - Develop and/or use a model } \\
\text { (including mathematical and } \\
\text { computational) to generate data to } \\
\text { support explanations, predict } \\
\text { phenomena, analyze systems, } \\
\text { and/or solve problems. }\end{array}$ \\
\hline
\end{tabular}




\section{Example of K-12} Progressions:

\section{Developing} and Using Models

\begin{tabular}{|c|c|c|c|c|}
\hline $\begin{array}{c}\text { Science and } \\
\text { Engineering Practices }\end{array}$ & K-2 Condensed Practices & 3-5 Condensed Practices & 6-8 Condensed Practices & 9-12 Condensed Practices \\
\hline \multirow{4}{*}{$\begin{array}{l}\text { Developing and Using } \\
\text { Models } \\
\text { A practice of both science } \\
\text { and engineering is to use } \\
\text { and construct models as } \\
\text { helpful tools for representing } \\
\text { ideas and explanations. } \\
\text { These tools include } \\
\text { diagrams, drawings, physical } \\
\text { replicas, mathematical } \\
\text { representations, analogies, } \\
\text { and computer simulations. } \\
\\
\text { Modeling tools are used to } \\
\text { develop questions, } \\
\text { predictions and explanations; } \\
\text { analyze and identify flaws in } \\
\text { systems; and communicate } \\
\text { ideas. Models are used to } \\
\text { build and revise scientific } \\
\text { explanations and proposed } \\
\text { engineered systems. } \\
\text { Measurements and } \\
\text { observations are used to } \\
\text { revise models and designs. }\end{array}$} & $\begin{array}{l}\text { Modeling in K-2 builds on priar } \\
\text { experiences and proaresses to } \\
\text { models (i.e., diagram, drawirn } \\
\text { physical replica, diorama, } \\
\text { dramatization, or storyboard) that } \\
\text { represent concrete events or } \\
\text { design solutions. }\end{array}$ & $\begin{array}{l}\text { Modeling in } 3-5 \text { builds on } \mathrm{K}-2 \\
\text { experiences and progresses to } \\
\text { and using models to represel } \\
\text { events and design solutions. }\end{array}$ & $\begin{array}{l}\text { Modeling in } 6-8 \text { builds on } \mathrm{K}-5 \\
\text { experiences and progresses to } \\
\text { models to describe, test, and } \\
\text { more abstract phenomena and } \\
\text { design systems. }\end{array}$ & $\begin{array}{l}\text { Modeling in 9-12 builds on } \mathrm{K}-8 \\
\text { experiences and progresses to using, } \\
\text { synthesizing, and developing models } \\
\text { to predict and show relationships } \\
\text { among variables between systems } \\
\text { and their components in the natural } \\
\text { and designed world(s). }\end{array}$ \\
\hline & $\begin{array}{l}\text { Distinguish between a model } \\
\text { and the actual object, process, } \\
\text { and/or events the model } \\
\text { represents. } \\
\text { Compare models to identify } \\
\text { common features and } \\
\text { differences. }\end{array}$ & - Identify limitations of models. & $\begin{array}{l}\text { - Evaluate limitations of a model for } \\
\text { a proposed object or tool. }\end{array}$ & $\begin{array}{l}\text { - Evaluate merits and limitations of } \\
\text { two different models of the same } \\
\text { proposed tool, process, mechanism, } \\
\text { or system in order to select or } \\
\text { revise a model that best fits the } \\
\text { evidence or design criteria. } \\
\text { - Design a test of a model to } \\
\text { ascertain its reliability. }\end{array}$ \\
\hline & $\begin{array}{l}\text { Develop and/or use a model to } \\
\text { represent amounts, } \\
\text { relationships, relative scales } \\
\text { (bigger, smaller), and/or } \\
\text { patterns in the natural and } \\
\text { designed world(s). }\end{array}$ & $\begin{array}{l}\text { - Collaboratively develop and/or } \\
\text { revise a model based on evidence } \\
\text { that shows the relationships } \\
\text { among variables for frequent and } \\
\text { regular occurring events. } \\
\text { Develop a model using an } \\
\text { analogy, example, or abstract } \\
\text { representation to describe a } \\
\text { scientific principle or design } \\
\text { solution. } \\
\text { Develop and/or use models to } \\
\text { describe and/or predict } \\
\text { phenomena. }\end{array}$ & $\begin{array}{l}\text { - Develop or modify a model-based } \\
\text { on evidence - to match what } \\
\text { happens if a variable or } \\
\text { component of a system is } \\
\text { changed. } \\
\text { - Use and/or develop a model of } \\
\text { simple systems with uncertain and } \\
\text { less predictable factors. } \\
\text { - Develop and/or revise a model to } \\
\text { show the relationships among } \\
\text { variables, including those that are } \\
\text { not observable but predict } \\
\text { observable phenomena. } \\
\text { - Develop and/or use a model to } \\
\text { predict and/or describe } \\
\text { phenomena. } \\
\text { Develop a model to describe } \\
\text { unobservable mechanisms. }\end{array}$ & $\begin{array}{l}\text { - Develop, revise, and/or use a model } \\
\text { based on evidencee to illustrate } \\
\text { and/or predict the relationships } \\
\text { between systems or between } \\
\text { components of a system. } \\
\text { - Develop and/or use multiple types } \\
\text { of models to provide mechanistic } \\
\text { accounts and/or predict } \\
\text { phenomena, and move flexibly } \\
\text { between model types based on } \\
\text { merits and limitations. }\end{array}$ \\
\hline & $\begin{array}{l}\text { Develop a simple model based } \\
\text { on evidence to represent a } \\
\text { proposed object or tool. }\end{array}$ & $\begin{array}{l}\text { Develop a diagram or simple } \\
\text { physical prototype to convey a } \\
\text { proposed object, tool, or process. } \\
\text { Use a model to test cause and } \\
\text { effect relationships or interactions } \\
\text { concerning the functioning of a } \\
\text { natural or designed system. }\end{array}$ & $\begin{array}{l}\text { - Develop and/or use a model to } \\
\text { generate data to test ideas about } \\
\text { phenomena in natural or designed } \\
\text { systems, including those } \\
\text { representing inputs and outputs, } \\
\text { and those at unobservable scales. }\end{array}$ & $\begin{array}{l}\text { - Develop a complex model that } \\
\text { allows for manipulation and testing } \\
\text { of a proposed process or system. } \\
\text { - Develop and/or use a model } \\
\text { (including mathematical and } \\
\text { computational) to generate data to } \\
\text { support explanations, predict } \\
\text { phenomena, analyze systems, } \\
\text { and/or solve problems. }\end{array}$ \\
\hline
\end{tabular}




\section{Example of K-12} Progressions:

\section{Developing} and Using Models

\begin{tabular}{|c|c|c|c|c|}
\hline $\begin{array}{c}\text { Science and } \\
\text { Engineering Practices }\end{array}$ & K-2 Condensed Practices & 3-5 Condensed Practices & 6-8 Condensed Practices & 9-12 Condensed Practices \\
\hline \multirow{3}{*}{$\begin{array}{l}\text { Developing and Using } \\
\text { Models } \\
\\
\text { A practice of both science } \\
\text { and engineering is to use } \\
\text { and construct models as } \\
\text { helpful tools for representing } \\
\text { ideas and explanations. } \\
\text { These tools include } \\
\text { diagrams, drawings, physical } \\
\text { replicas, mathematical } \\
\text { representations, analogies, } \\
\text { and computer simulations. }\end{array}$} & $\begin{array}{l}\text { Modeling in } \mathrm{K}-2 \text { builds on priar } \\
\text { experiences and progresses to }\end{array}$ & $\begin{array}{l}\text { Modeling in } 3-5 \text { builds on } \mathrm{K}-2 \\
\text { experiences and progresses to }\end{array}$ & $\begin{array}{l}\text { Modeling in 6-8 builds on K-5 } \\
\text { experiences and progresses to }\end{array}$ & $\begin{array}{l}\text { Modeling in } 9-12 \text { builds on } \mathrm{K}-8 \\
\text { experiences and progresses to }\end{array}$ \\
\hline & $\begin{array}{l}\text { models (i.e., diagram, drawirn ot } \\
\text { physical replica, diorama, } \\
\text { dramatization, or storyboard) that } \\
\text { represent concrete events or } \\
\text { design solutions. }\end{array}$ & $\begin{array}{l}\text { and using models to represer } \\
\text { events and design solutions. }\end{array}$ & $\begin{array}{l}\text { models to describe, test, and dict } \\
\text { more abstract phenomena and } \\
\text { design systems. }\end{array}$ & $\begin{array}{l}\text { to predict and show relations } \\
\text { among variables between systems } \\
\text { and their components in the natural } \\
\text { and designed world(s). }\end{array}$ \\
\hline & $\begin{array}{l}\text { Distinguish between a model } \\
\text { and the actual object, process, } \\
\text { and/or events the model } \\
\text { represents. } \\
\text {. Compare models to identify } \\
\text { common features and } \\
\text { differences. }\end{array}$ & - Identify limitations of models. & $\begin{array}{l}\text { Evaluate limitations of a model for } \\
\text { a proposed object or tool. }\end{array}$ & $\begin{array}{l}\text { Evaluate merits and limitations of } \\
\text { two different models of the same } \\
\text { proposed tool, process, mechanism, } \\
\text { or system in order to select or } \\
\text { revise a model that best fits the } \\
\text { evidence or design criteria. } \\
\text { Design a test of a model to } \\
\text { ascertain its reliability. }\end{array}$ \\
\hline \multirow[t]{2}{*}{$\begin{array}{l}\text { Modeling tools are used to } \\
\text { develop questions, } \\
\text { predictions and explanations; } \\
\text { analyze and identify flaws in } \\
\text { systems; and communicate } \\
\text { ideas. Models are used to } \\
\text { build and revise scientific } \\
\text { explanations and proposed } \\
\text { engineered systems. } \\
\text { Measurements and } \\
\text { observations are used to } \\
\text { revise models and designs. }\end{array}$} & $\begin{array}{l}\text { Develop and/or use a model to } \\
\text { represent amounts, } \\
\text { relationships, relative scales } \\
\text { (bigger, smaller), and/or } \\
\text { patterns in the natural and } \\
\text { designed world(s). }\end{array}$ & $\begin{array}{l}\text { - Collaboratively develop and/or } \\
\text { revise a model based on evidence } \\
\text { that shows the relationships } \\
\text { among variables for frequent and } \\
\text { regular occurring events. } \\
\text { - Develop a model using an } \\
\text { analogy, example, or abstract } \\
\text { representation to describe a } \\
\text { scientific principle or design } \\
\text { solution. } \\
\text { Develo and/or use models to } \\
\text { describe and/or predict } \\
\text { phenomena. }\end{array}$ & $\begin{array}{l}\text { - Develop or modify a model-based } \\
\text { on evidence - to match what } \\
\text { happens if a variable or } \\
\text { component of a system is } \\
\text { changed. } \\
\text { - Use and/or develop a model of } \\
\text { simple systems with uncertain and } \\
\text { less predictable factors. } \\
\text { - Develop and/or revise a model to } \\
\text { show the relationships among } \\
\text { variables, including those that are } \\
\text { not observable but predict } \\
\text { observable phenomena. } \\
\text { Develop and/or use a model to } \\
\text { predict and//or describe } \\
\text { phenomena. } \\
\text { Develop a model to describe } \\
\text { unobservable mechanisms. }\end{array}$ & $\begin{array}{l}\text { - Develop, revise, and/or use a mode } \\
\text { based on evidence te illustrate } \\
\text { and//or predict the relationships } \\
\text { between systems or between } \\
\text { components of a system. } \\
\text { - Develop and/or use multiple types } \\
\text { of models to provide mechanistic } \\
\text { accounts and/or predict } \\
\text { phenomena, and move flexibly } \\
\text { between model types based on } \\
\text { merits and limitations. }\end{array}$ \\
\hline & $\begin{array}{l}\text { Develop a simple model based } \\
\text { on evidence to represent a } \\
\text { proposed object or tool. }\end{array}$ & $\begin{array}{l}\text { Develop a diagram or simple } \\
\text { physical prototype to convey a } \\
\text { proposed object, tool, or process. } \\
\text { Use a model to test cause and } \\
\text { effect relationships or interactions } \\
\text { concerning the functioning of a } \\
\text { natural or designed system. }\end{array}$ & $\begin{array}{l}\text { Develop and/or use a model to } \\
\text { generate data to test ideas about } \\
\text { phenomena in natural or designed } \\
\text { systems, including those } \\
\text { representing inputs and outputs, } \\
\text { and those at unobservable scales. }\end{array}$ & $\begin{array}{l}\text { Develop a complex model that } \\
\text { allows for manipulation and testing } \\
\text { of a proposed process or system. } \\
\text { Develop and/or use a model } \\
\text { (including mathematical and } \\
\text { computational) to generate data to } \\
\text { support explanations, predict } \\
\text { phenomena, analyze systems, } \\
\text { and/or solve problems. }\end{array}$ \\
\hline
\end{tabular}




\section{Example} of K-12

Progressions:

\section{Developing} and Using Models

\begin{tabular}{|c|c|c|c|c|}
\hline $\begin{array}{c}\text { Science and } \\
\text { Engineering Practices }\end{array}$ & K-2 Condensed Practices & 3-5 Condensed Practices & 6-8 Condensed Practices & 9-12 Condensed Practices \\
\hline $\begin{array}{l}\text { Developing and Using } \\
\text { Models } \\
\text { A practice of both science } \\
\text { and engineering is to use } \\
\text { and construct models as } \\
\text { helpful tools for representing }\end{array}$ & $\begin{array}{l}\text { Modeling in } \mathrm{K}-2 \text { builds on priar } \\
\text { experiences and proaresses to } \\
\text { models (i.e., diagram, drawiris, } \\
\text { physical replica, diorama, } \\
\text { dramatization, or storyboard) that } \\
\text { represent concrete events or } \\
\text { design solutions. }\end{array}$ & $\begin{array}{l}\text { and using models to repre } \\
\text { events and design solution }\end{array}$ & $\begin{array}{l}\text { models to describe, test, and edict } \\
\text { more abstract phenomena and } \\
\text { design systems. }\end{array}$ & $\begin{array}{l}\text { among variables between systems } \\
\text { and their components in the natural } \\
\text { and designed world(s). }\end{array}$ \\
\hline $\begin{array}{l}\text { These tools include } \\
\text { diagrams, drawings, physical } \\
\text { replicas, mathematical } \\
\text { representations, analogies, } \\
\text { and computer simulations. } \\
\text { Modeling tools are used to }\end{array}$ & $\begin{array}{l}\text { Distinguish between a model } \\
\text { and the actual object, process, } \\
\text { and/or events the model } \\
\text { represents. } \\
\text { Compare models to identify } \\
\text { common features and } \\
\text { differences. }\end{array}$ & - Identify limitations of models. & $\begin{array}{l}\text { Evaluate limitations of a model for } \\
\text { a proposed object or tool. }\end{array}$ & $\begin{array}{l}\text { Evaluate merits and limitations of } \\
\text { two different models of the same } \\
\text { proposed tool, process, mechanism, } \\
\text { or system in order to select or } \\
\text { revise a model that best fits the } \\
\text { evidence or design criteria. } \\
\text { Design a test of a model to } \\
\text { ascertain its reliability. }\end{array}$ \\
\hline $\begin{array}{l}\text { develop questions, } \\
\text { predictions and explanations; } \\
\text { analyze and identify flaws in } \\
\text { systems; and communicate } \\
\text { ideas. Models are used to } \\
\text { build and revise scientific } \\
\text { explanations and proposed } \\
\text { engineered systems. }\end{array}$ & $\begin{array}{l}\text { Develop and/or use a model to } \\
\text { represent amounts, } \\
\text { relationships, relative scales } \\
\text { (bigger, smaller), and/or } \\
\text { patterns in the natural and } \\
\text { designed world(s). }\end{array}$ & $\begin{array}{l}\text { Collaboratively develop and/or } \\
\text { revise a model based on evidence } \\
\text { that shows the relationships } \\
\text { among variables for frequent and } \\
\text { regular occurring events. } \\
\text { - Develop a model using an } \\
\text { analogy, example, or abstract }\end{array}$ & $\begin{array}{l}\text { Develop or modify a model-based } \\
\text { on evidence - to match what } \\
\text { happens if a variable or } \\
\text { component of a system is } \\
\text { changed. } \\
\text { - Use and/or develop a model of } \\
\text { simple systems with uncertain and }\end{array}$ & $\begin{array}{l}\text { Develop, revise, and/or use a model } \\
\text { based on evidence to illustrate } \\
\text { and/or predict the relationships } \\
\text { between systems or between } \\
\text { components of a system. } \\
\text { Develop and/or use multiple types } \\
\text { of models to provide mechanistic }\end{array}$ \\
\hline
\end{tabular}

\section{Also Grade-Banded Progressions for Disciplinary Core Ideas, Crosscutting Concepts, Engineering/Technology/Applications of Science, and Nature of Science}

concerning the functioning of a natural or designed system. and those at unobservable scales.

computational) to generate data support explanations, predict phenomena, analyze systems, 


\section{Any NGSS-designed Curricular Materials Should Incorporate the "Five NGSS Innovations"}

1. Three-Dimensional Learning

2. Building K-12 Progressions

3. Alignment with Common Core English Language Arts and Mathematics 


\section{Connections} to Common Core Math and ELA:

\section{HS-ESS3-1 Earth and Human Activity}

Students who demonstrate understanding can:

HS-ESS3-1. Construct an explanation based on evidence for how the availability of natural resources, occurrence of natura hazards, and changes in climate have influenced human activity. [Clarification Statement: Examples of key natural resources include access to fresh water (such as rivers, lakes, and groundwater), regions of fertile soils such as river deltas, and high concentrations of minerals and fossil fuels. Examples of natural hazards can be from interior processes (such as volcanic eruptions and earthquakes), surface processes (such as tsunamis, mass wasting and soil erosion), and severe weather (such as hurricanes, floods, and droughts). Examples of the results of changes in climate that can affect populations or drive mass migrations include changes to sea level, regional patterns of temperature and precipitation, and the types of crops and livestock that can be raised.]

\section{PRACTICES}

Constructing Explanations and Designing

Solutions

Constructing explanations and designing solutions in 9-12 builds on $\mathrm{K}-8$ experiences and progresses to explanations and designs that are supported by multiple and independent student-generated sources of principles, and theories.

principles, and theories. Construct an explanation based on valid and reliable evidence obtained from a variety of sources (including students' own investigations, models, theories, simulations, peer review) describe the natural world operate today as they did in the past and will continue to do as they future.

\section{X-CUTTING CONCEPTS}

\section{BIG IDEAS}

ESS3.A: Natural Resources

Resource availability has guided the development of human society.

ESS3.B: Natural Hazards

- Natural hazards and other geologic events have shaped the course of human history; [they] have significantly altered the sizes of human populations and have driven human migrations.

\section{Cause and Effect}

- Empirical evidence is required to differentiate between cause and correlation and make claims about specific causes and effects.

......

Connections to Engineering, Technology, and Applications of Science

Influence of Science, Engineering, and Technology on Society and the Natural World

- Modern civilization depends on major technological systems.
Connections to other DCls in this grade-band: N/A

Articulation of DCls across grade-bands:

MS.LS2.A ; MS.LS4.D ; MS.ESS2.A ; MS.ESS3.A ; MS.ESS3.B

Common Core State Standards Connections:

ELA/Literacy -

RST.11-12.1 Cite specific textual evidence to support analysis of science and technical texts, attending to important distinctions the author makes and to any gaps or RST.11-12.1 inconsistencies in the account. (HS-ESS3-1)

WHST.9-12.2 Write informative/explanatory texts, including the narration of historical events, scientific procedures/ experiments, or technical processes. (HS-ESS3-1)

Mathematics

MP.2

Reason abstractly and quantitatively. (HS-ESS3-1)

Use units as a way to understand problems and to guide the solution of multi-step problems; choose and interpret units consistently in formulas; choose

and interpret the scale and the origin in graphs and data displays. (HS-ESS3-1)

HSN.Q.A.3 Choose a level of accuracy appropriate to limitations on measurement when reporting quantities. (HS-ESS3-1) 


\section{Connections} to Common Core Math and ELA:

\section{HS-ESS3-1 Earth and Human Activity}

Students who demonstrate understanding can:

HS-ESS3-1. Construct an explanation based on evidence for how the availability of natural resources, occurrence of natura hazards, and changes in climate have influenced human activity. [Clarification Statement: Examples of key natural resources include access to fresh water (such as rivers, lakes, and groundwater), regions of fertile soils such as river deltas, and high concentrations of minerals and fossil fuels. Examples of natural hazards can be from interior processes (such as volcanic eruptions and earthquakes), surface processes (such as tsunamis, mass wasting and soil erosion), and severe weather (such as hurricanes, floods, and droughts). Examples of the results of changes in climate that can affect populations or drive mass migrations include changes to sea level, regional patterns of temperature and precipitation, and the types of crops and livestock that can be raised.]

\section{PRACTICES}

Constructing Explanations and Designing

Solutions

Constructing explanations and designing solutions in $9-12$ builds on $\mathrm{K}-8$ experiences and progresses to explanations and designs that are supported by multiple and independent student-generated sources of principles, and theories.

principles, and theories. Construct an explanation based on valid and reliable evidence obtained from a variety of sources (including students' own investigations, models, theories, simulations, peer review) describe the natural world operate today as they did in the pas and will continue to do as in they future.

\section{X-CUTTING CONCEPTS}

\section{BIG IDEAS}

Resource availability has guided the development of human society.

ESS3.B: Natural Hazards

- Natural hazards and other geologic events have shaped the course of human history; [they] have significantly altered the sizes of human populations and have driven human migrations.
ESS3.A: Natural Resources

\section{Cause and Effect}

- Empirical evidence is required to differentiate between cause and correlation and make claims about specific causes and effects.

.......

Connections to Engineering, Technology, and Applications of Science

Influence of Science, Engineering, and Technology on Society and the Natural World

- Modern civilization depends on major technological systems.
Connections to other DCls in this grade-band: N/A

Articulation of DCls across grade-bands:

Contections

Common Core State Standards Connections:

ELA/Literacy -

RST.11-12.1 Cite specific textual evidence to support analysis of science and technical texts, attending to important distinctions the author makes and to any gaps or RST.11-12.1 $\quad$ inconsistencies in the account. (HS-ESS3-1)

WHST.9-12.2 Write informative/explanatory texts, including the narration of historical events, scientific procedures/ experiments, or technical processes. (HS-ESS3-1)

Mathemetics -

MP.2

HSN.QA.1 Reason abstractly and quantitatively. (HS-ESS3-1)

and interpret the scale and the origin in graphs and data displays. (HS-ESS3-1)

Define appropriate quantities for the purpose of descriptive modeling.

HSN.Q.A.3 
Connections to Common Core Math and ELA:

\section{The Practices of Science and Engineering (SEPs)}

1. Asking questions (for science) and
defining problems (for engineering)
2. Developing and using models
3. Planning and carrying out
investigations
4. Analyzing and interpreting data
English
Connections




\section{Any NGSS-designed Curricular Materials Should Incorporate the "Five NGSS Innovations"}

1. Three-Dimensional Learning

2. Building K-12 Progressions

3. Alignment with Common Core English Language Arts and Mathematics

4. Making Sense of Phenomena and Designing Solutions to Problems 


\section{NGSS: $\rightarrow$ Problem-Based Learning}

$>$ Creates a more student-centric environment

$>$ Moves the focus away from the teacher's instruction toward the student's active learning process

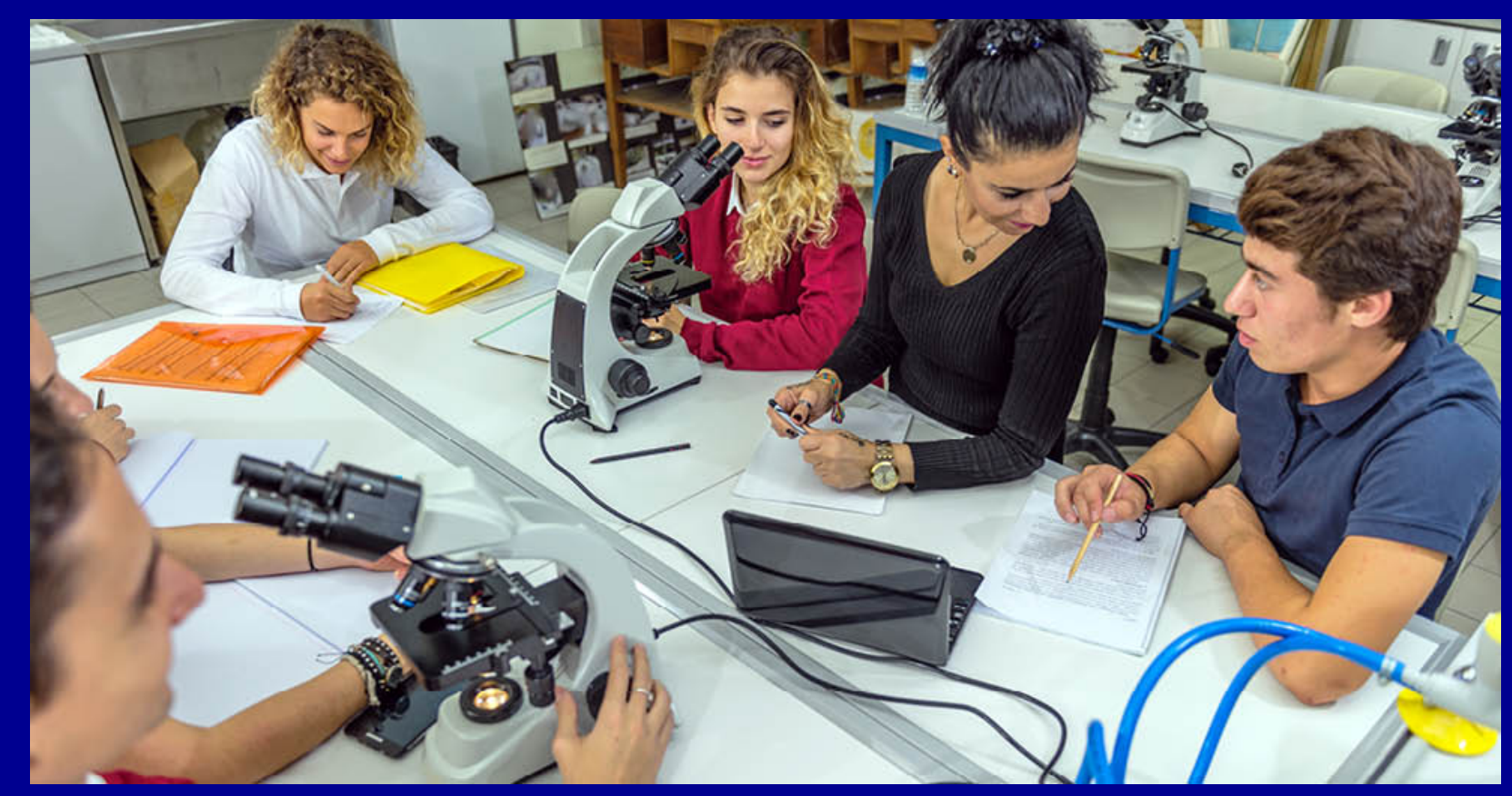




\section{Phenomenon-Based Learning}

$>$ Phenomena are defined through broad big-picture questions

$>$ Issues are usually of human relevance

$>$ Challenges are approached holistically, viewed from a variety of perspectives

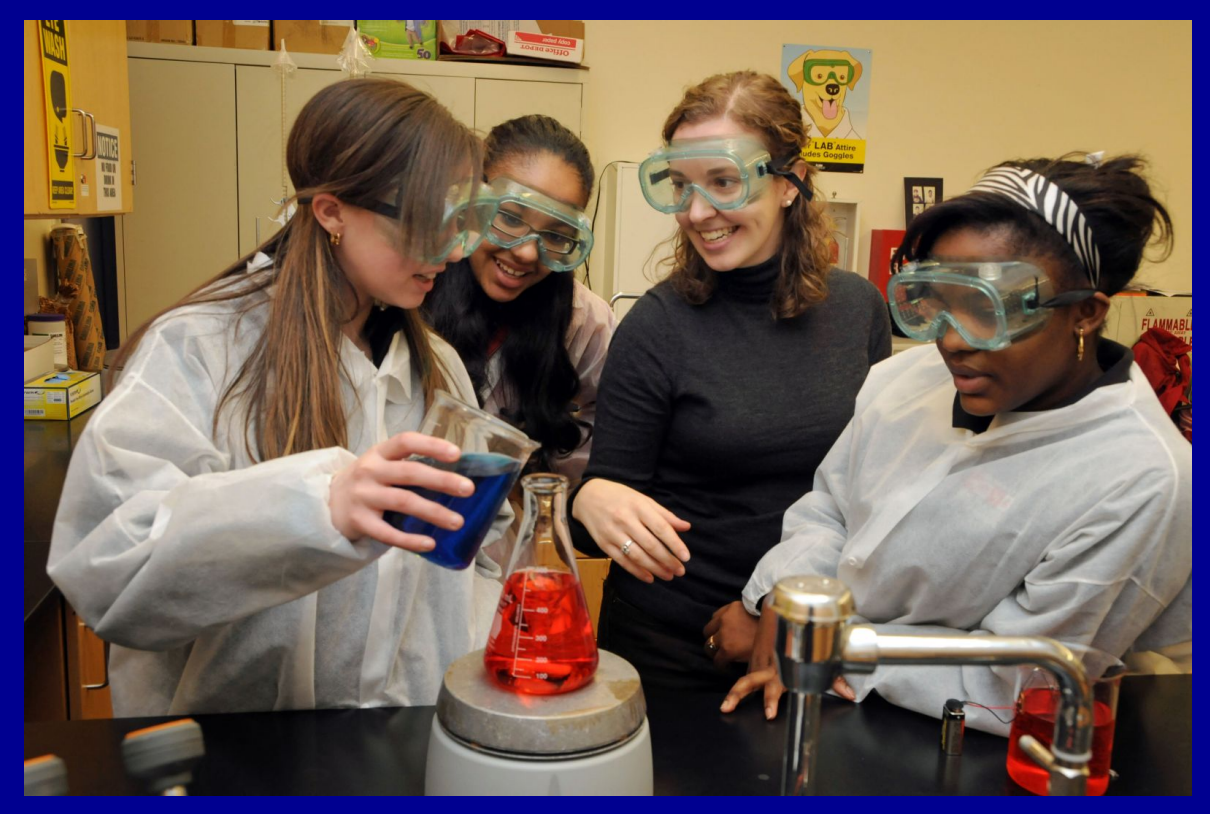




\section{Phenomenon-Based Learning}

$>$ Student sense-making and solution-designing should be the context for student learning and a window into student understanding of all three dimensions of the standards

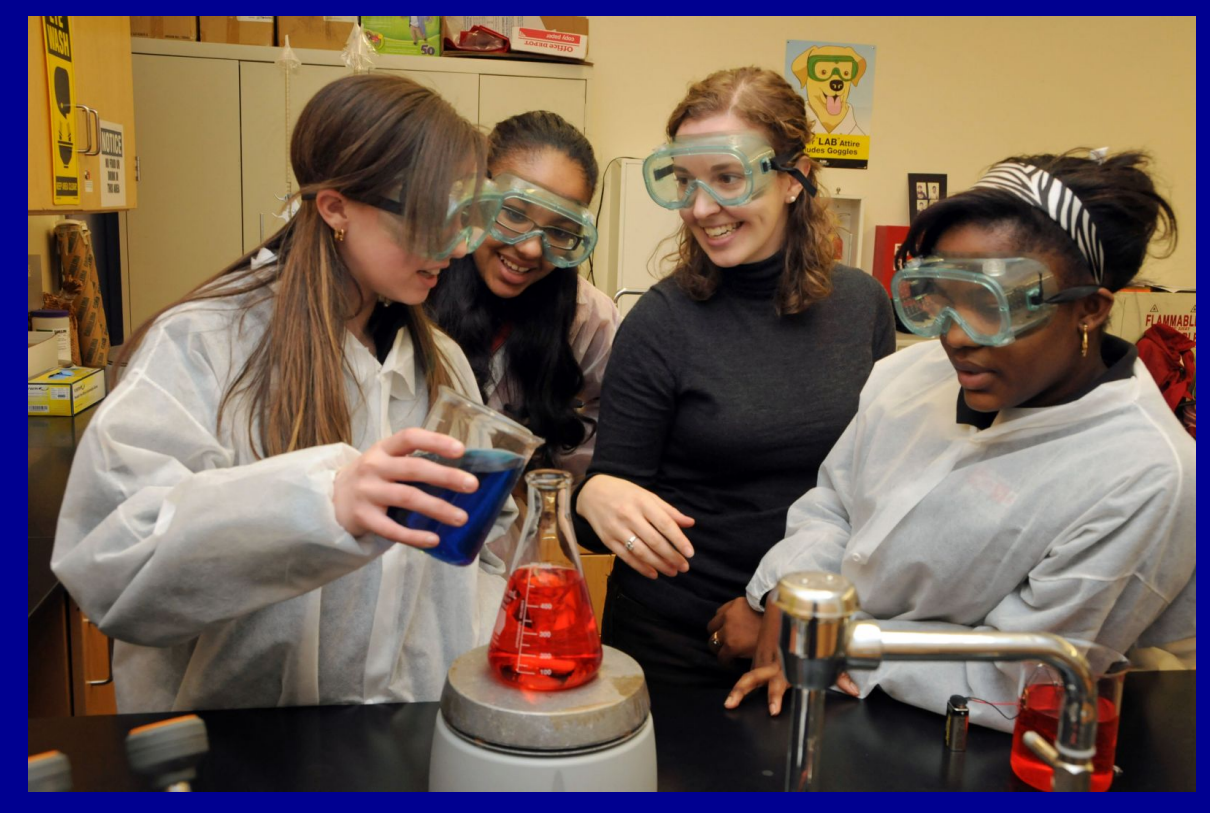




\section{Three-Dimensional Learning}




\section{Three-Dimensional Learning}

1. Just DCls = Encyclopedia 


\section{Three-Dimensional Learning}

1. Just DCls = Encyclopedia

2. Just SEPs $=$ Random activities 


\section{Three-Dimensional Learning}

1. Just DCls = Encyclopedia

2. Just SEPs $=$ Random activities

3. Just CCCs $=$ Random science phenomena 


\section{Three-Dimensional Learning}

1. Just DCls = Encyclopedia

2. Just SEPs $=$ Random activities

3. Just CCCs $=$ Random science phenomena

4. DCls + CCCs = Old-Fashioned Textbook 


\section{Three-Dimensional Learning}

1. Just DCls = Encyclopedia

2. Just SEPs $=$ Random activities

3. Just CCCs $=$ Random science phenomena

4. $\mathrm{DCls}+\mathrm{CCCs}=$ Old-Fashioned Textbook

5. SEPs $+\mathrm{DCls}=$ List of science labs 


\section{Three-Dimensional Learning}

1. Just DCls = Encyclopedia

2. Just SEPs $=$ Random activities

3. Just CCCs $=$ Random science phenomena

4. $\mathrm{DCls}+\mathrm{CCCs}=$ Old-Fashioned Textbook

5. SEPs + DCls $=$ List of science labs

6. SEPs + CCCs $=$ Telling stories of science phenomena 


\section{Three-Dimensional Learning}

1. Just DCls = Encyclopedia

2. Just SEPs = Random activities

3. Just CCCs $=$ Random science phenomena

4. $\mathrm{DCls}+\mathrm{CCCs}=$ Old-Fashioned Textbook

5. SEPs + DCls $=$ List of science labs

6. SEPs $+\mathrm{CCCs}=$ Telling stories of science phenomena

7. SEPs $+\mathrm{DCls}+\mathrm{CCCs}=$ Coherent curriculum of science and engineering practices, connected to disciplinary core ideas, organized around storylines of understanding that build and apply ideas across time 


\section{Any NGSS-designed Curricular Materials Should Incorporate the Five "NGSS Innovations"}

1. Three-Dimensional Learning

2. Building K-12 Progressions

3. Alignment with Common Core English Language Arts and Mathematics

4. Making Sense of Phenomena and Designing Solutions to Problems

5. All Standards, All Students 


\section{Any NGSS-designed Curricul Incorporate the Five "NGSS I}

1. Three-Dimensional Learning

2. Building K-12 Progressions

3. Alignment with Common Core NGSS FOR ALL STUDENTS Arts and Mathematics

4. Making Sense of Phenomena Solutions to Problems

5. All Standards, All Students 


\section{Accelerated Model Course Pathway:}

\section{5-Year Model}

(For Gifted Students)

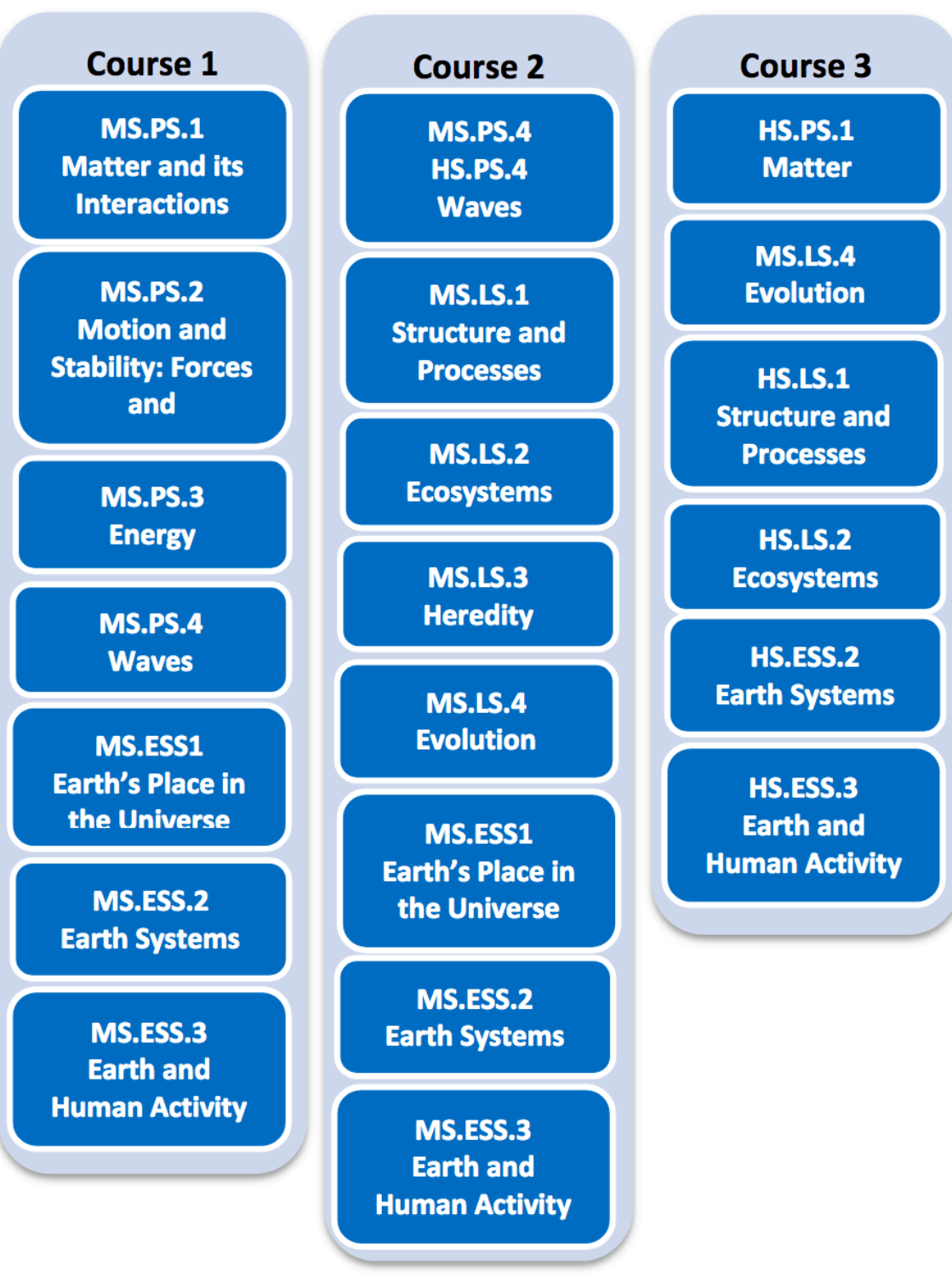

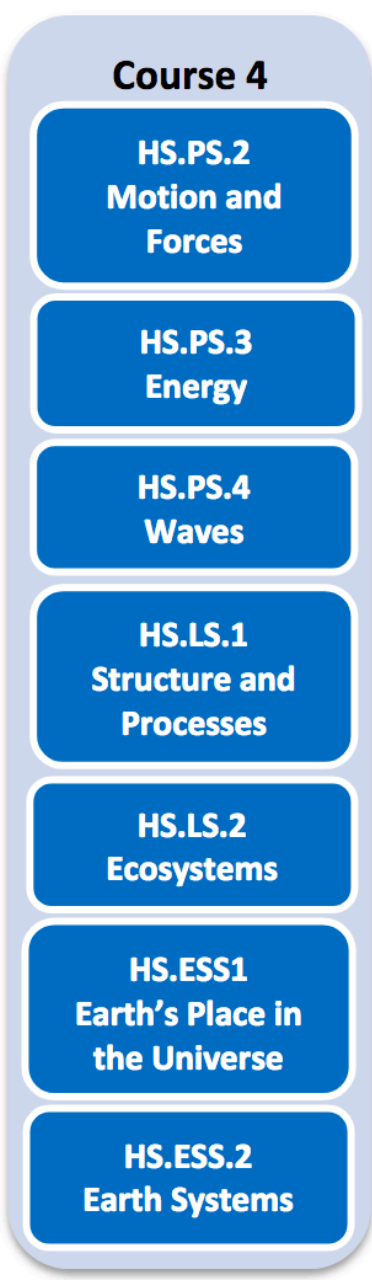

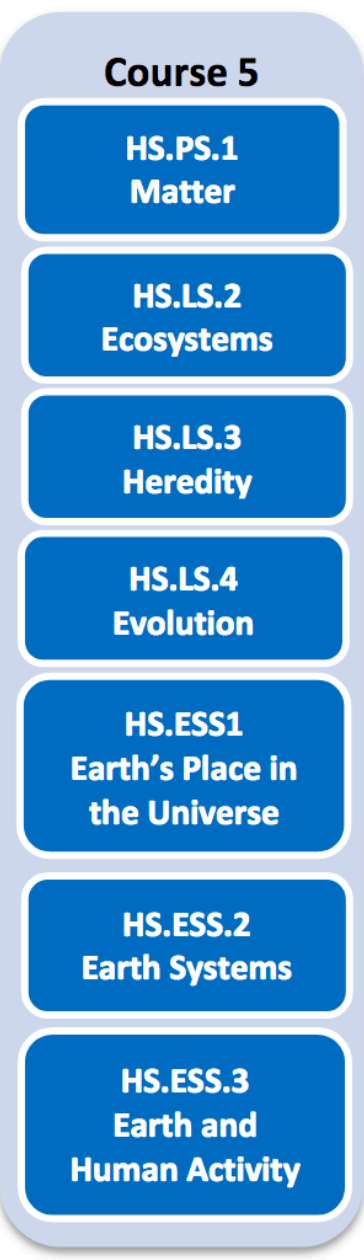




\section{Accelerated Model Course Pathway:}

\section{4-Year Model}

(For Very Gifted Students)

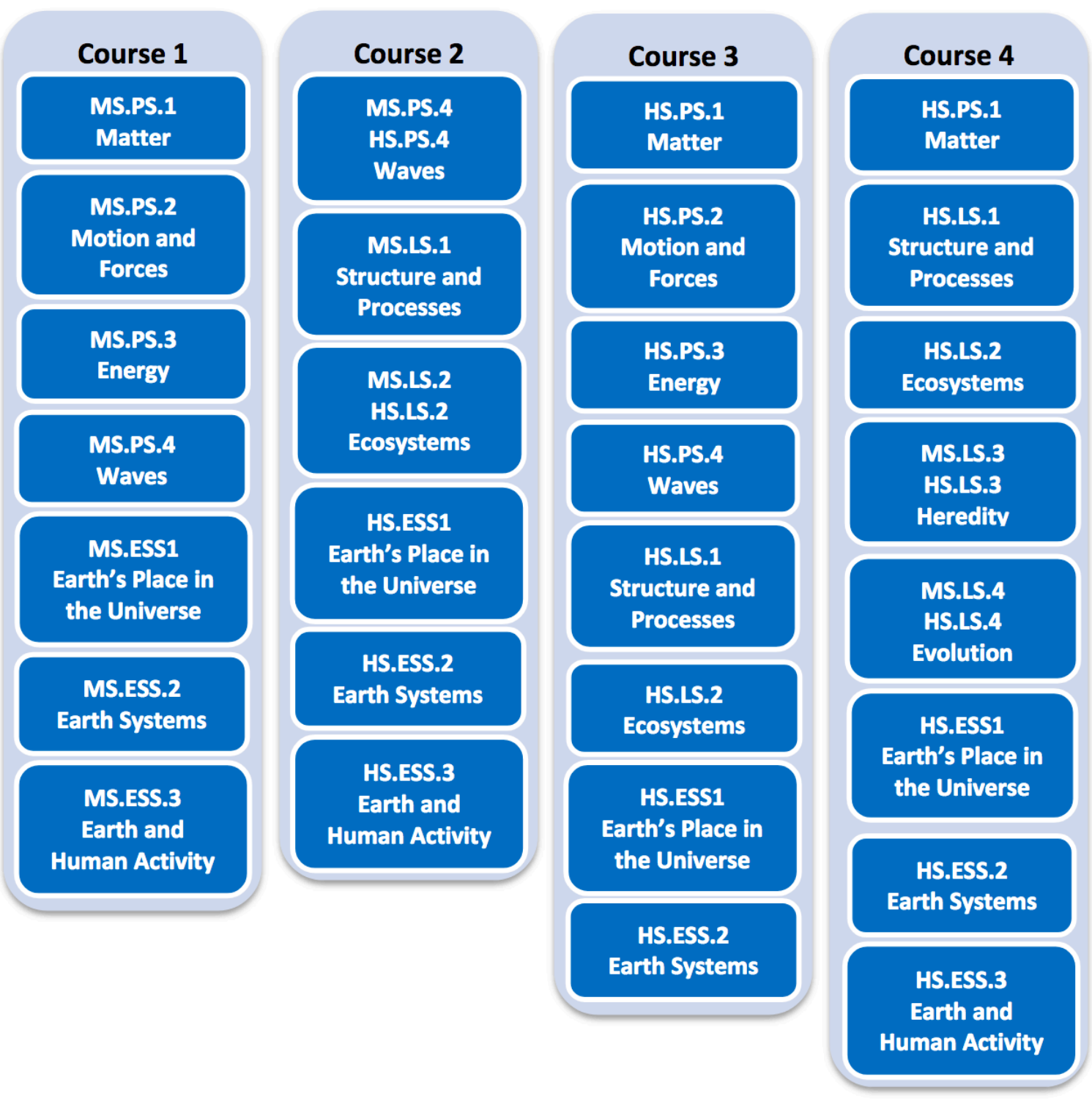




\section{Elevate Science}

(Michael Padilla,

Zipporah Miller, Michael Wysession)

An NGSS-designed K-8 science program combining print workbooks with interactive online materials

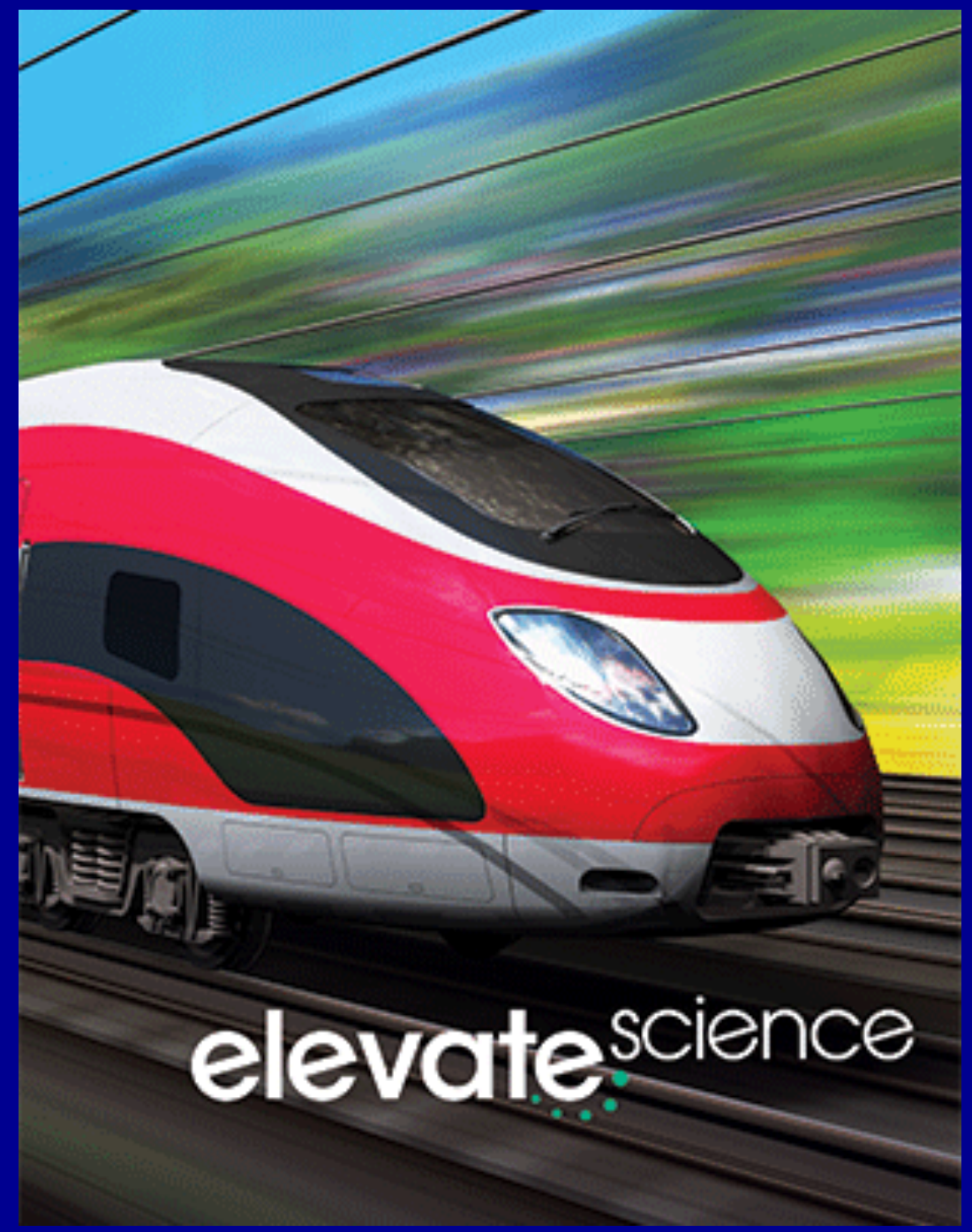




\section{Timeline for the NGSS \& Elevate Science}

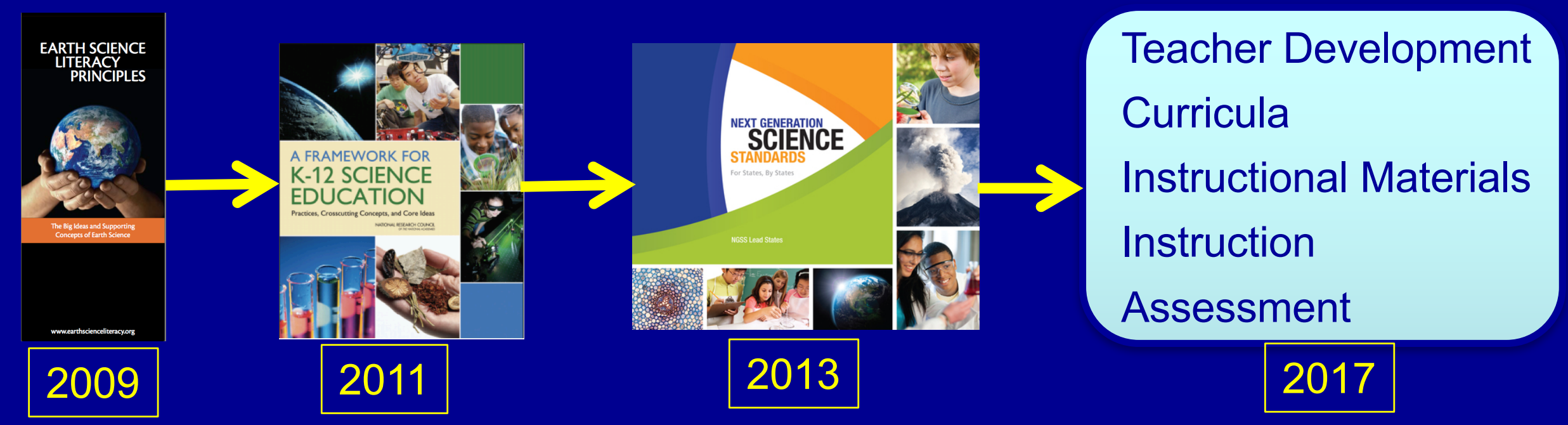




\section{Timeline for the NGSS \& Elevate Science}

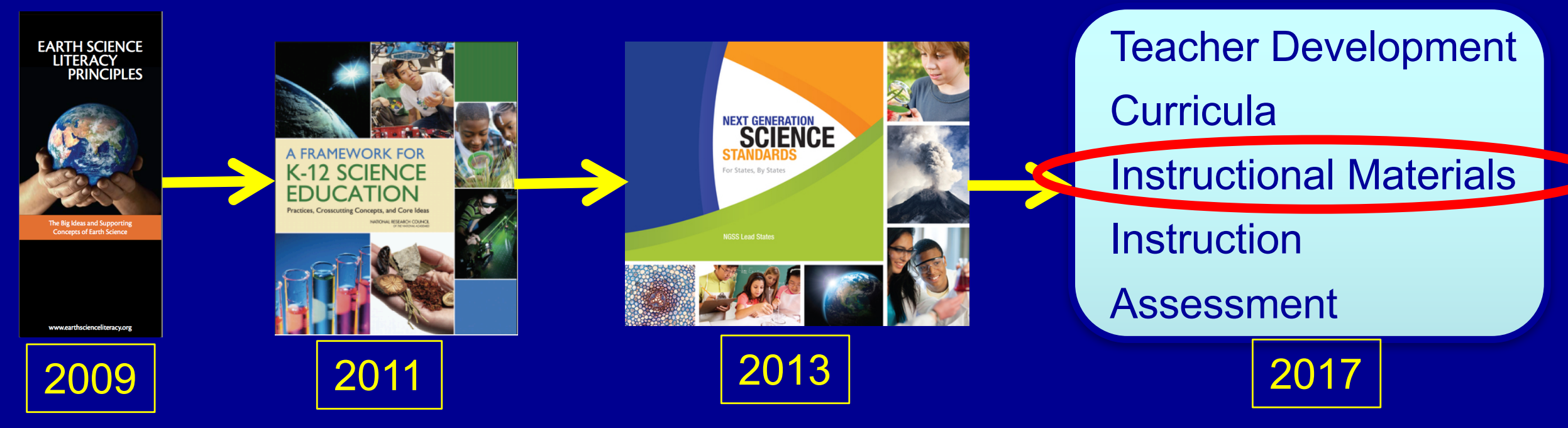




\section{Timeline for the NGSS \& Elevate Science}

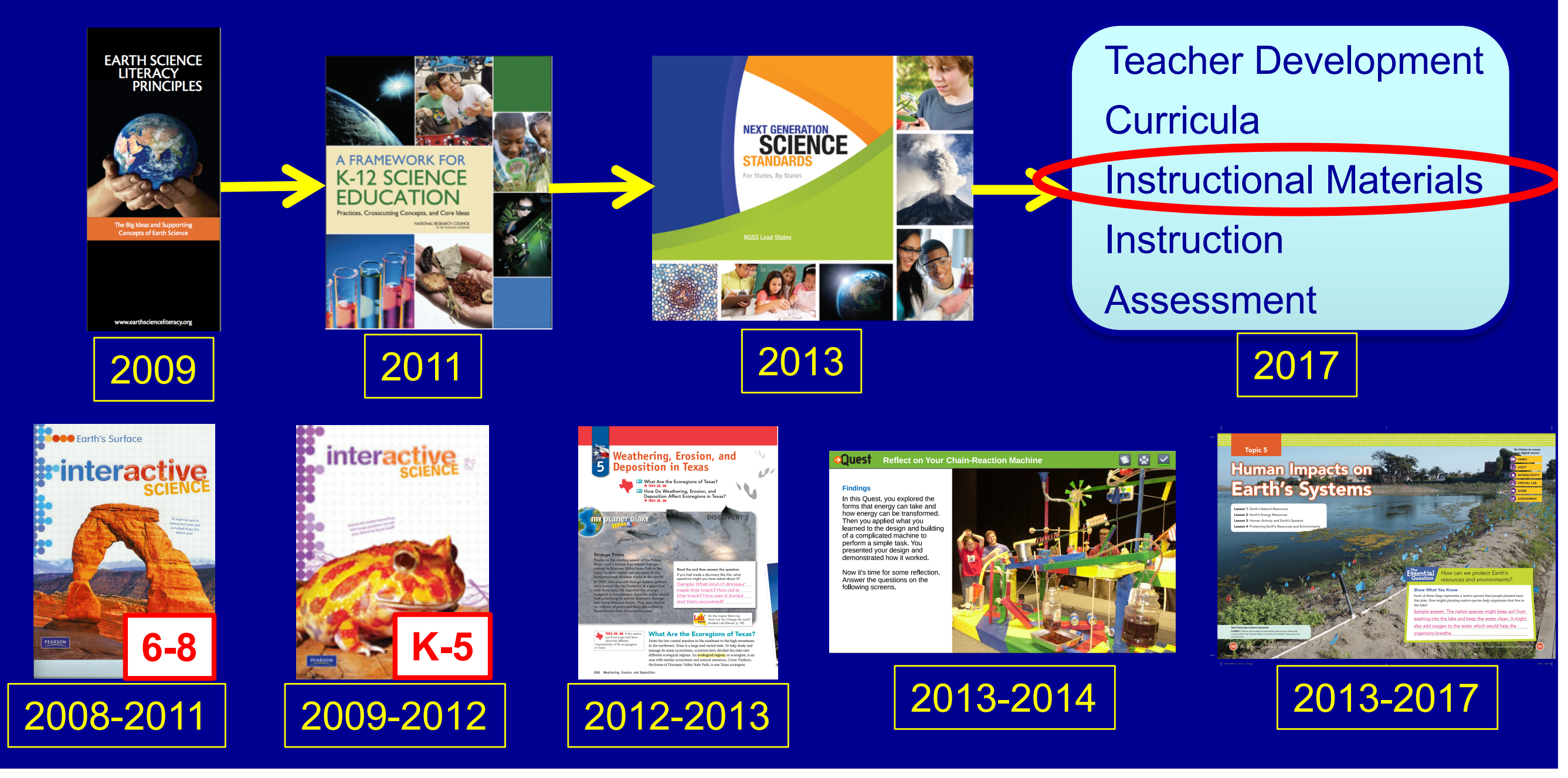




\section{Publisher Challenges}

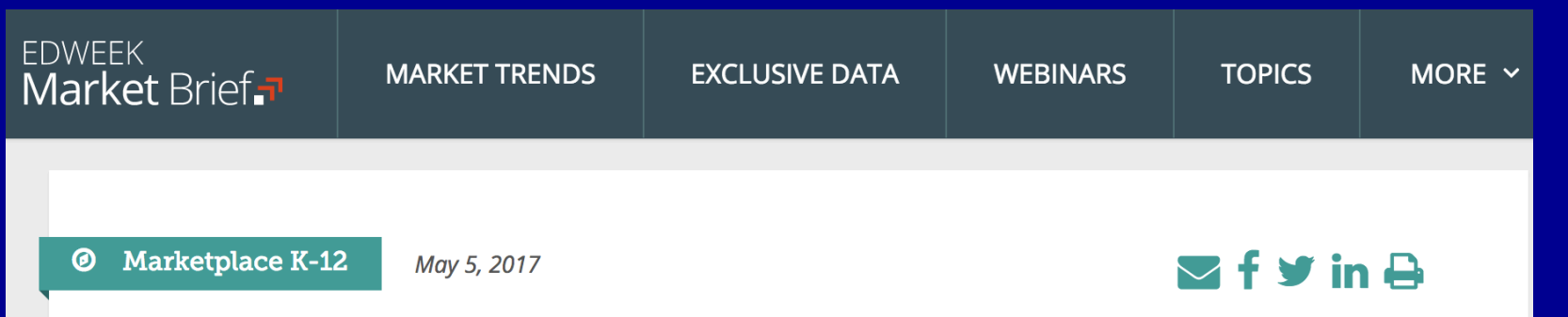

Pearson Explores Sale of Its U.S. K-12 Curriculum Business

\section{Michele Molnar \\ Associate Editor}

Pearson, the largest education company in the world, announced today that it's considering selling off its U.S. K-12 digital and print curriculum business, citing the "slow pace of digital adoption" in schools.

Besides that issue, the company cited a "challenging competitive and market environment" and the high capital needs of the digital curriculum market as reasons for its announcement of a strategic review of that portion of the business. 


\section{NGSS State-wise Adoption}

Adopting Arkansas

States: California

Connecticut

Delaware

Hawaii

Illinois

lowa

Kansas

Kentucky

Maryland

Michigan

Nevada

N. Hampshire

New Jersey

Oregon

Rhode IsI.

Vermont

Washington (and DC)

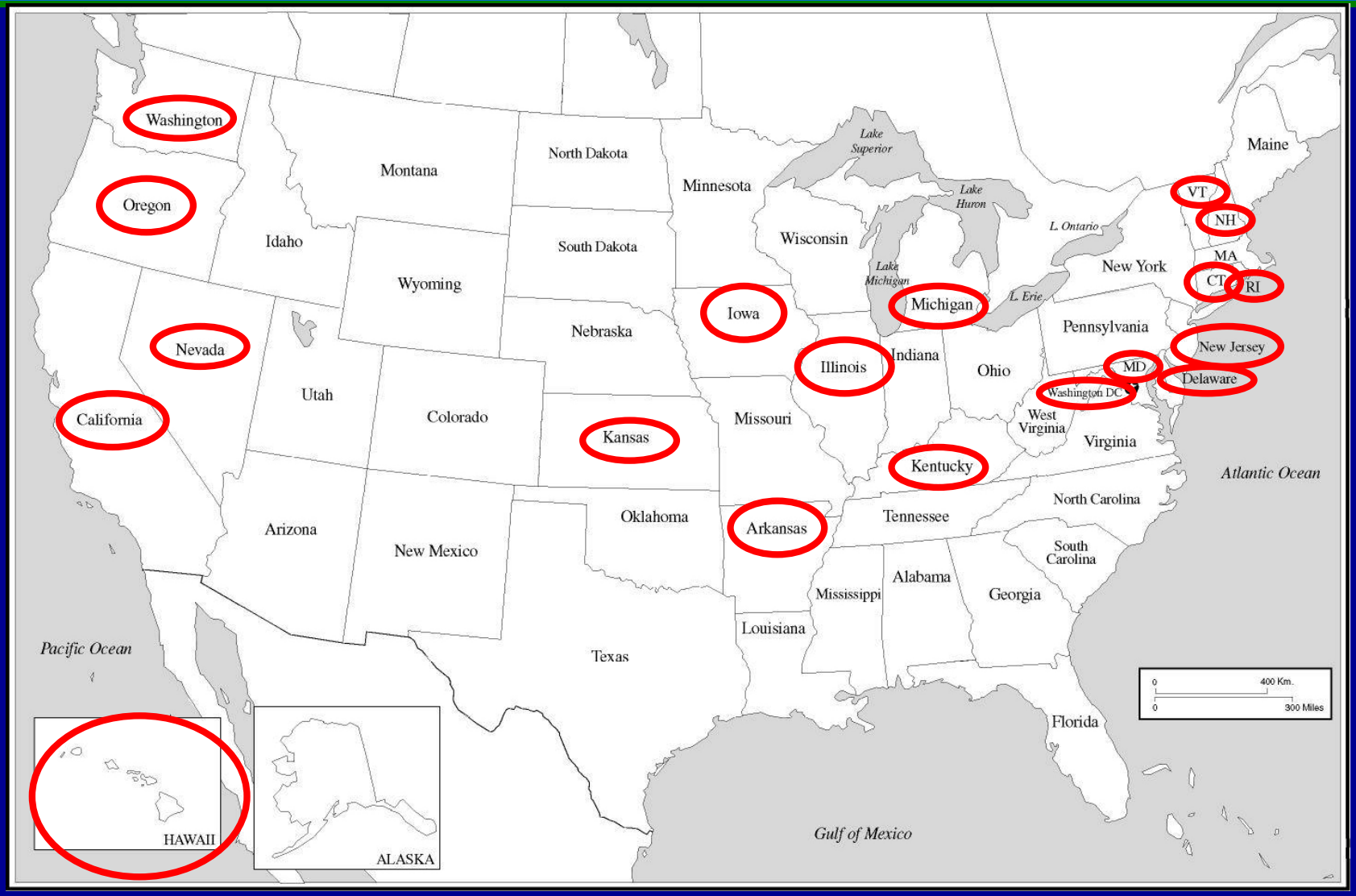




\section{NGSS State-wise Adoption}

Adopting Arkansas

States: California

Connecticut

Delaware

Hawaii

Illinois

lowa

Kansas

Kentucky

Maryland

Michigan

Nevada

N. Hampshire

New Jersey

Oregon

Rhode IsI.

Vermont

Washington (and DC)

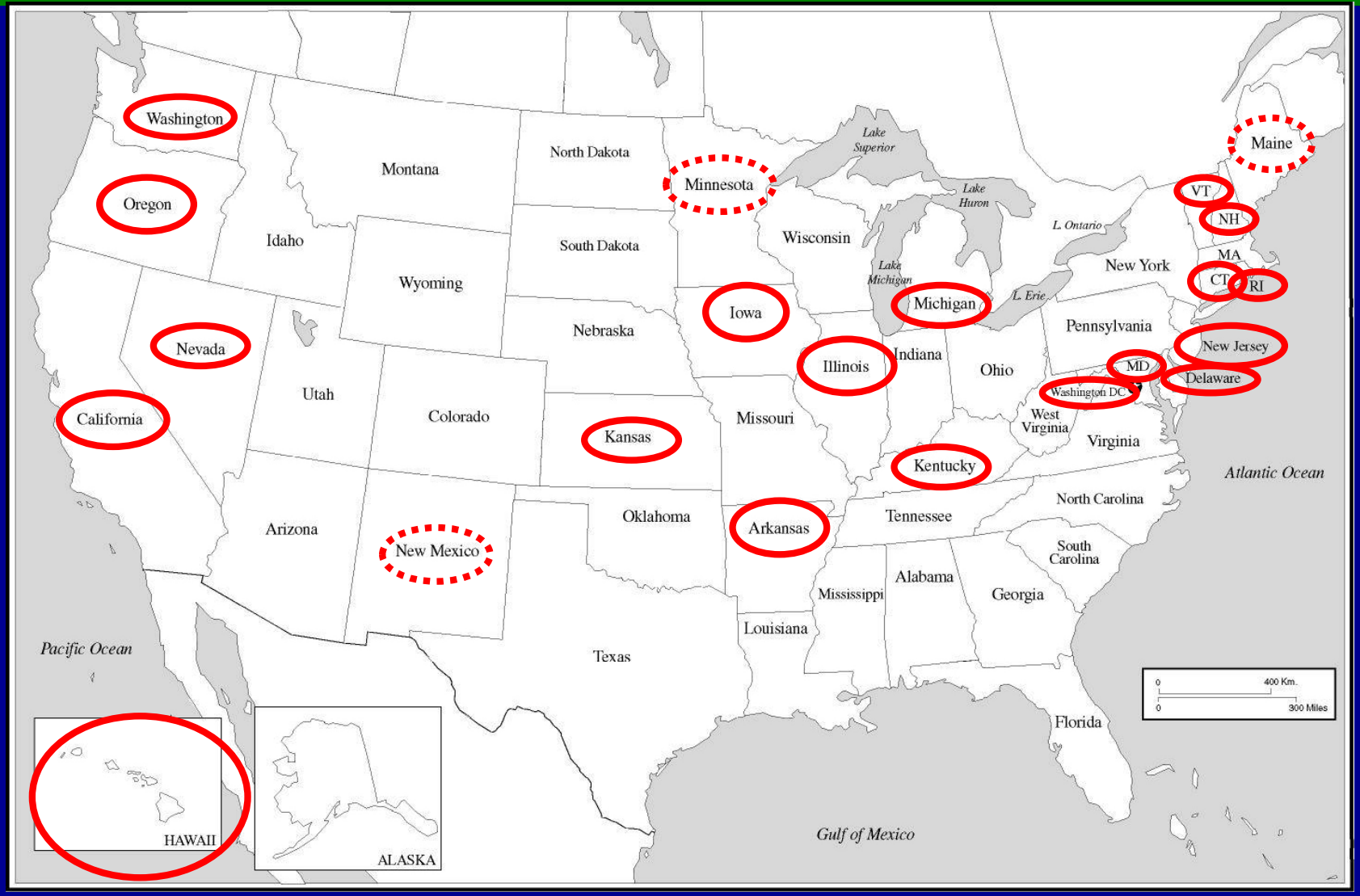




\section{NGSS State-wise Adoption}

\section{Adopting Arkansas} States:

California

Connecticut

Delaware

Hawaii

Illinois

lowa

Kansas

Kentucky

Maryland

Michigan

Nevada

N. Hampshire

New Jersey

Oregon

Rhode Isl.

Vermont

Washington (and DC)

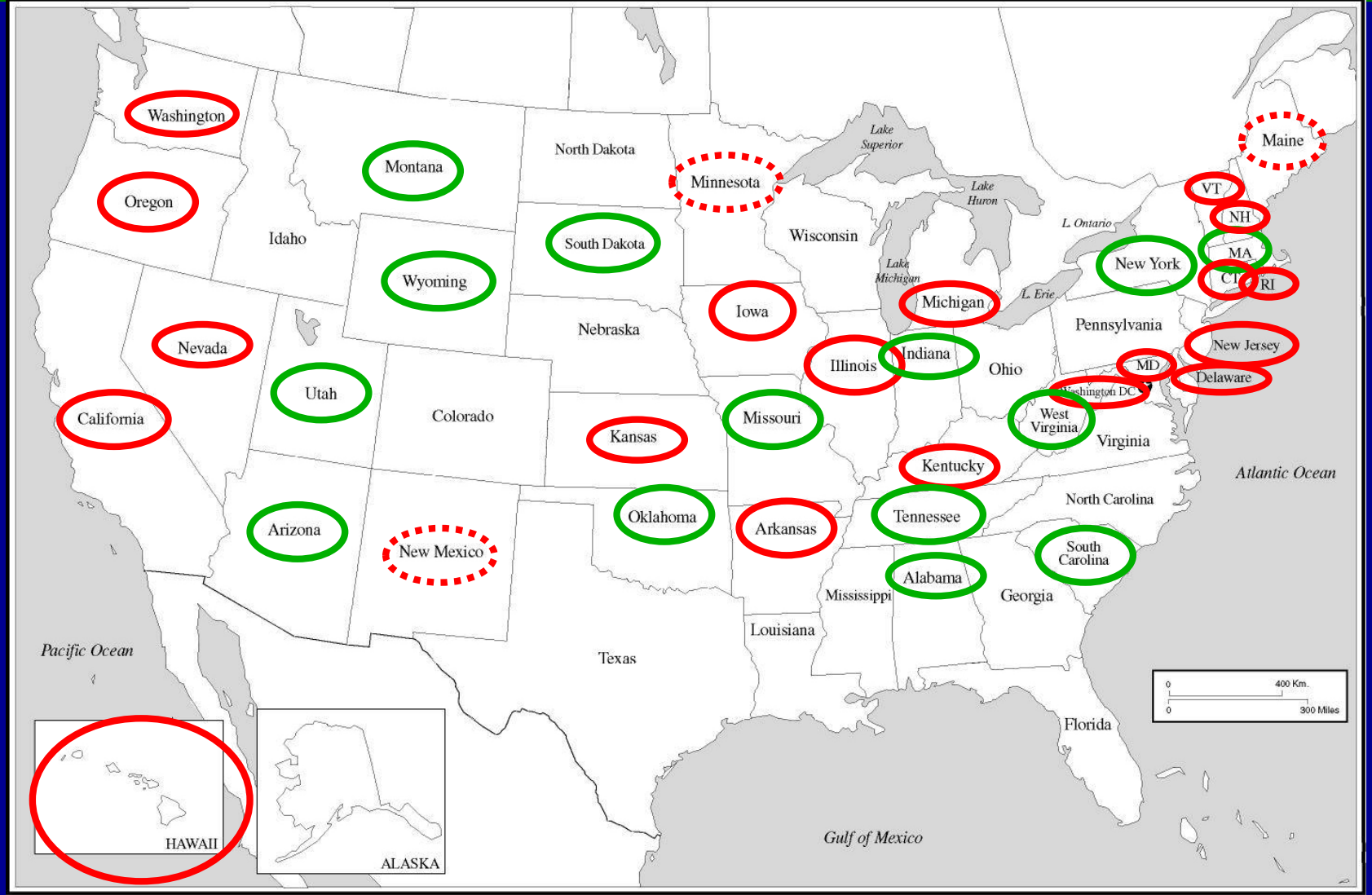

Adapting: Alabama, Arizona, Massachusetts, Missouri, Montana, New York, Oklahoma, S. Carolina, S. Dakota, Tennessee, Utah, West Virginia, Wyoming 


\section{NGSS State-wise Adoption}

\section{Adopting Arkansas} States:

California

Connecticut

Delaware

Hawaii

Illinois

lowa

Kansas

Kentucky

Maryland

Michigan

Nevada

N. Hampshire

New Jersey

Oregon

Rhode Isl.

Vermont

Washington (and DC)

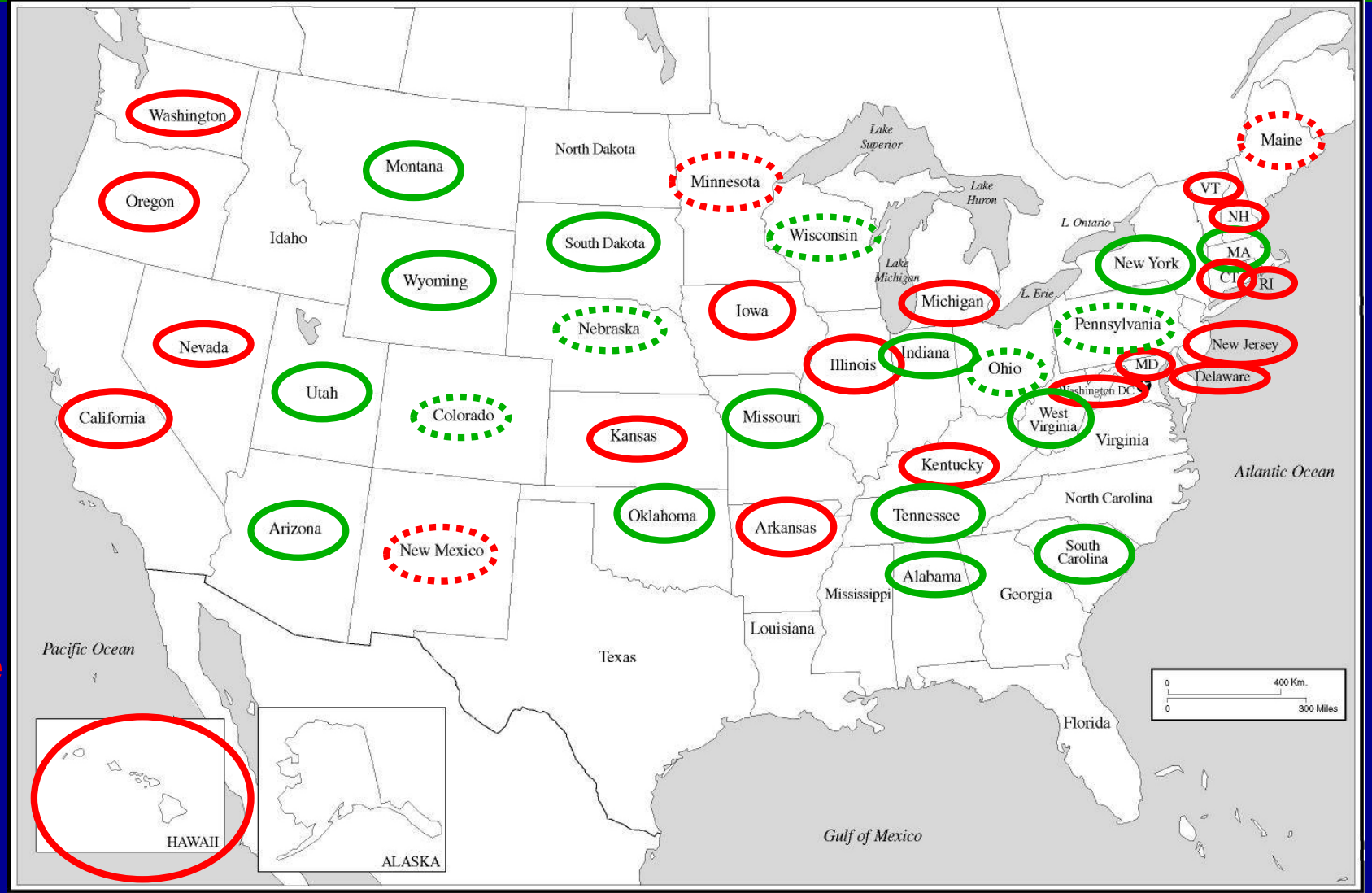

Adapting: Alabama, Arizona, Massachusetts, Missouri, Montana, New York, Oklahoma, S. Carolina, S. Dakota, Tennessee, Utah, West Virginia, Wyoming 


\section{NGSS State-wise Adoption}

\section{Adopting Arkansas} States:

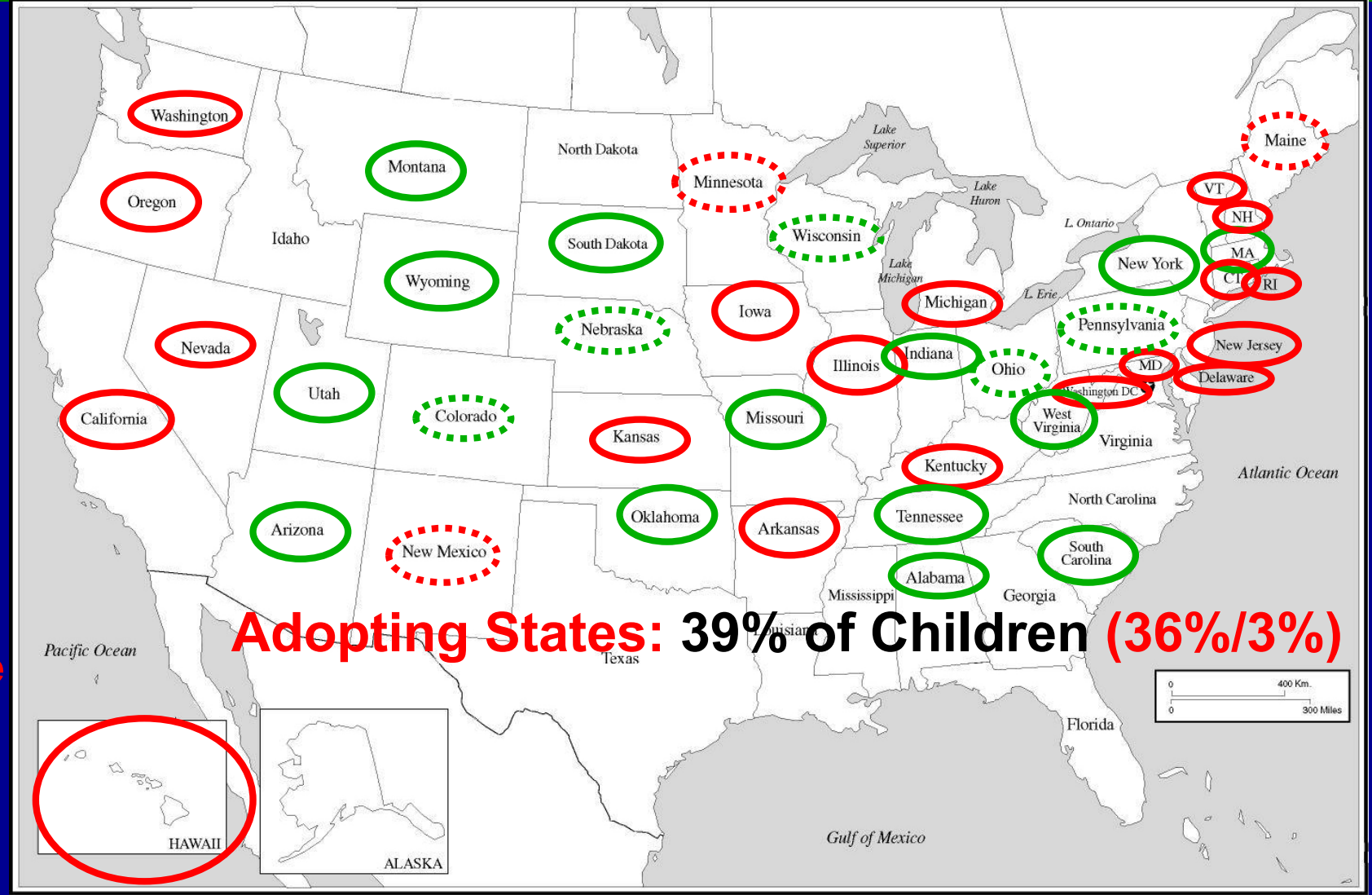

Adapting: Alabama, Arizona, Massachusetts, Missouri, Montana, New York, Oklahoma, S. Carolina, S. Dakota, Tennessee, Utah, West Virginia, Wyoming 


\section{NGSS State-wise Adoption}

\section{Adopting Arkansas} States:

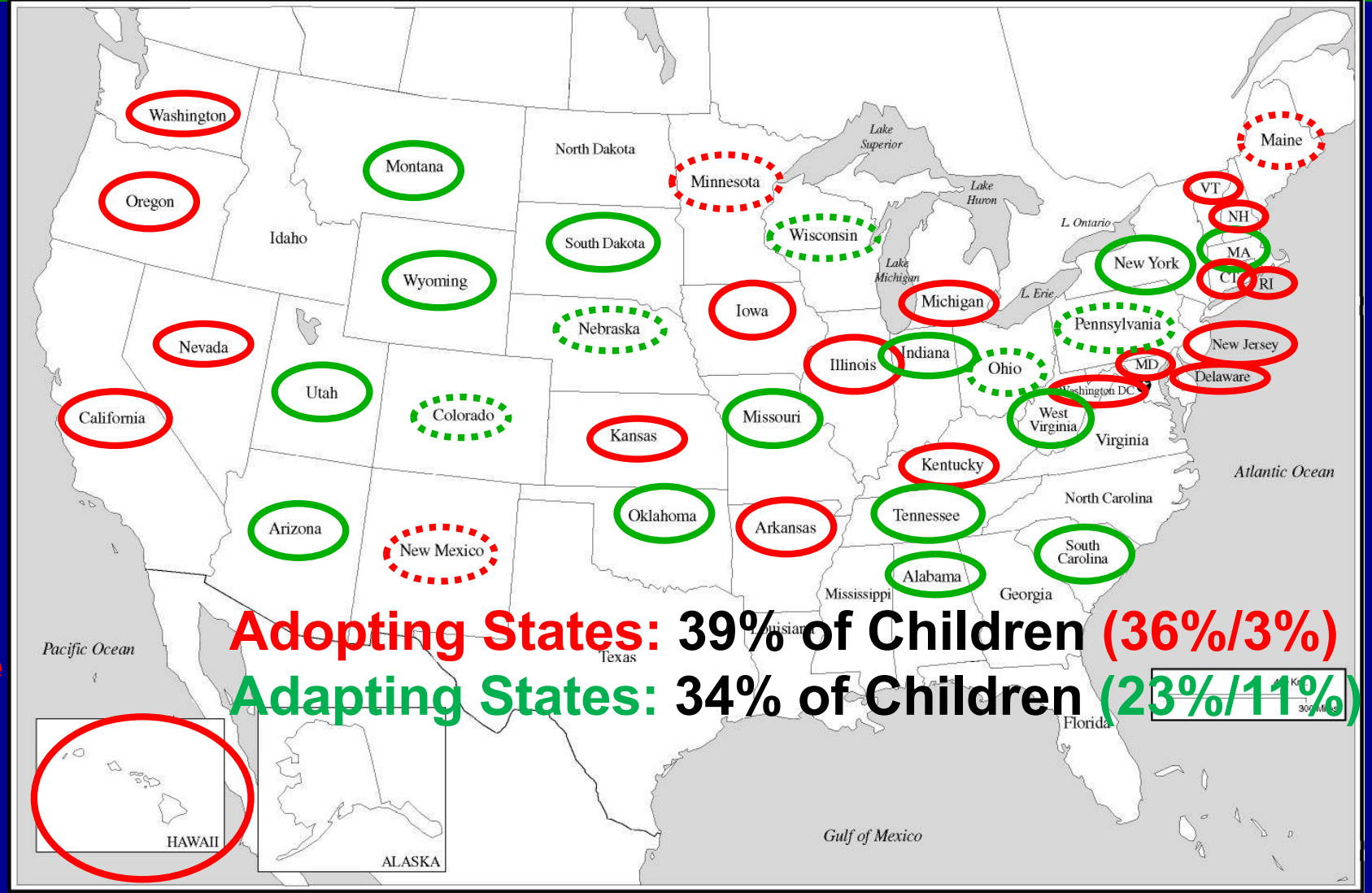

Adapting: Alabama, Arizona, Massachusetts, Missouri, Montana, New York, Oklahoma, S. Carolina, S. Dakota, Tennessee, Utah, West Virginia, Wyoming 


\section{NGSS State-wise Adoption}

Adopting Arkansas States:

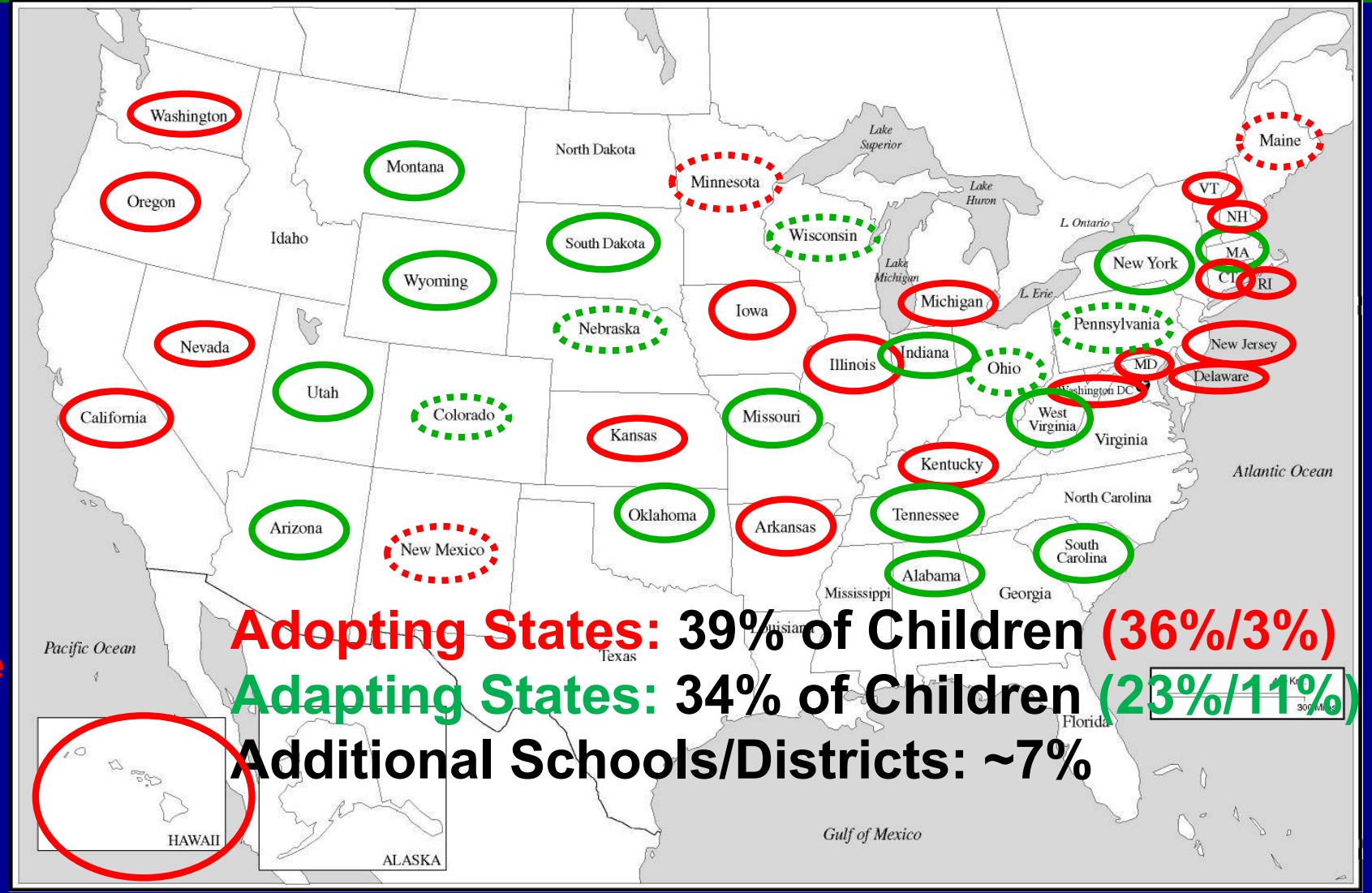

Adapting: Alabama, Arizona, Massachusetts, Missouri, Montana, New York, Oklahoma, S. Carolina, S. Dakota, Tennessee, Utah, West Virginia, Wyoming 


\section{NGSS State-wise Adoption}

Adopting Arkansas States:

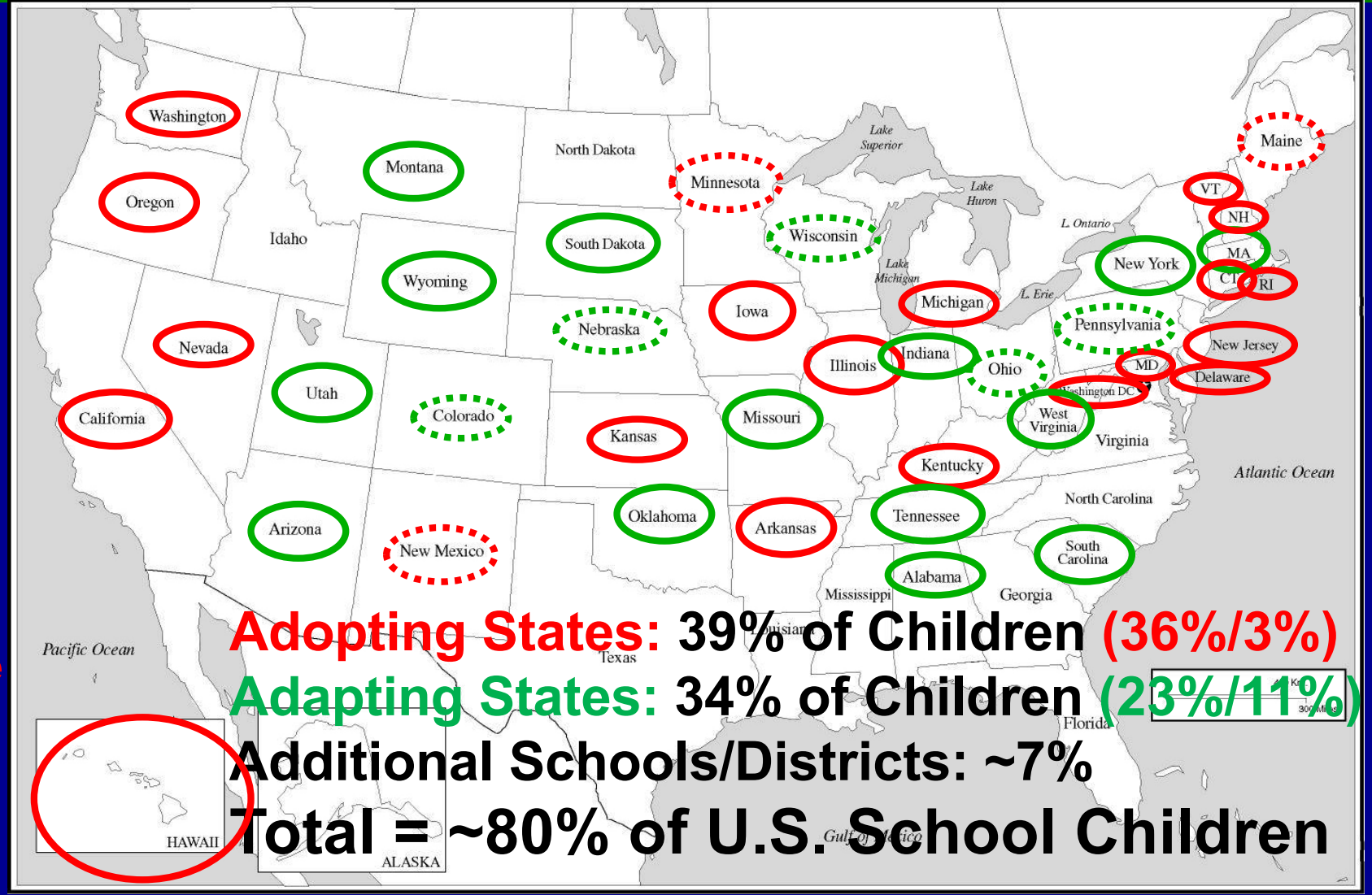

Adapting: Alabama, Arizona, Massachusetts, Missouri, Montana, New York, Oklahoma, S. Carolina, S. Dakota, Tennessee, Utah, West Virginia, Wyoming 
Every state (and maybe district!) will teach their NGSSadopted or adapted curriculum differently

What content should Instructional Materials include? 
Every state (and maybe district!) will teach their NGSSadopted or adapted curriculum differently

What content should Instructional Materials include?

K-5 (easier): NGSS is grade-leveled 


\section{Every state (and maybe district!) will teach their NGSS- adopted or adapted curriculum differently}

What content should Instructional Materials include?

K-5 (easier): NGSS is grade-leveled

6-8 (harder): NGSS is grade-banded 


\section{Constructing NGSS-designed Instructional Materials}

\section{Appendix K -- Course Map \#1: Conceptual Understanding Model}

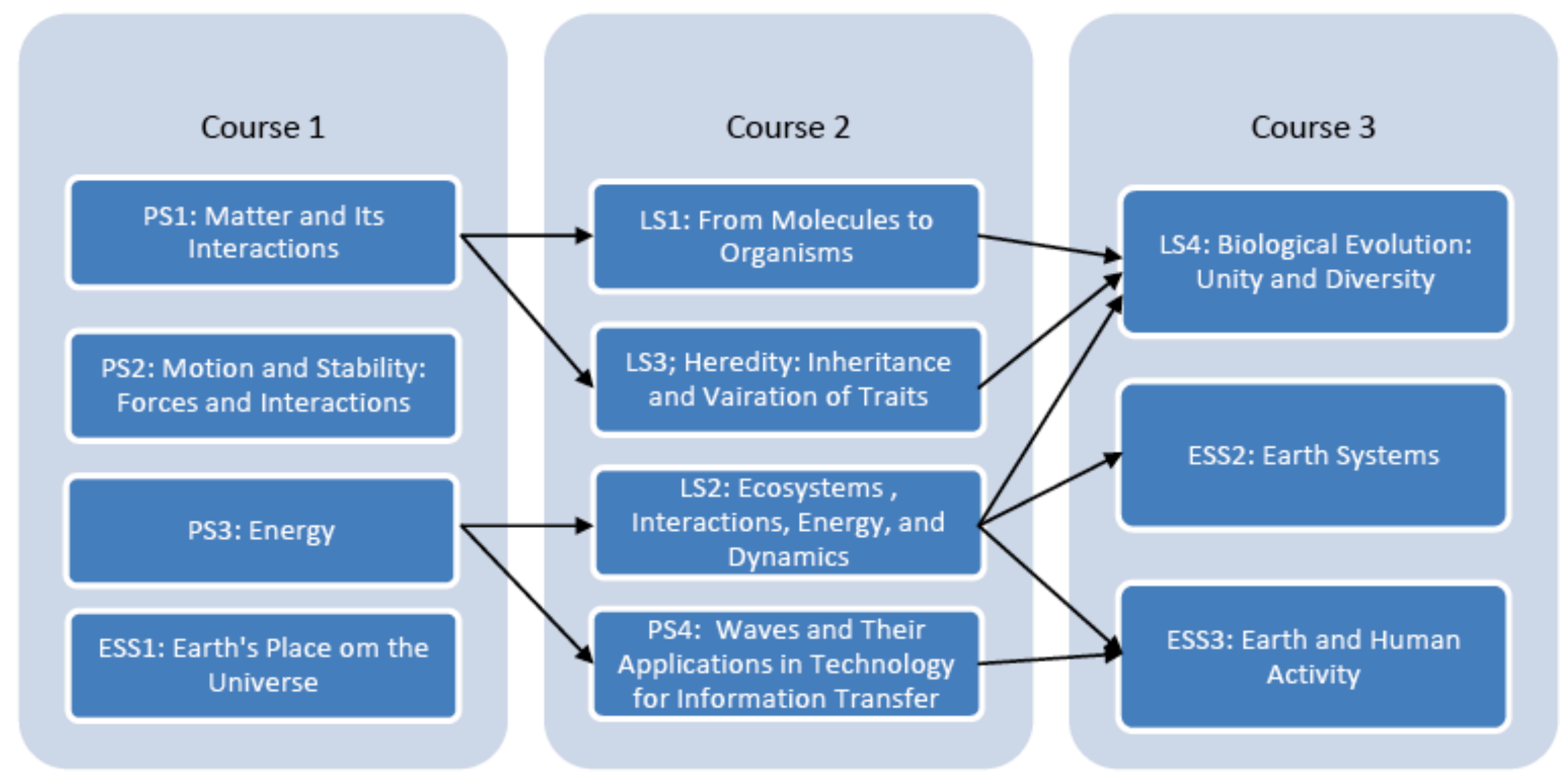




\section{Course Map \#2: Science Domains Model}

The 3 courses are Physical Science, Life Science, and Earth and Space Science (for either middle or high school)

Physical Science

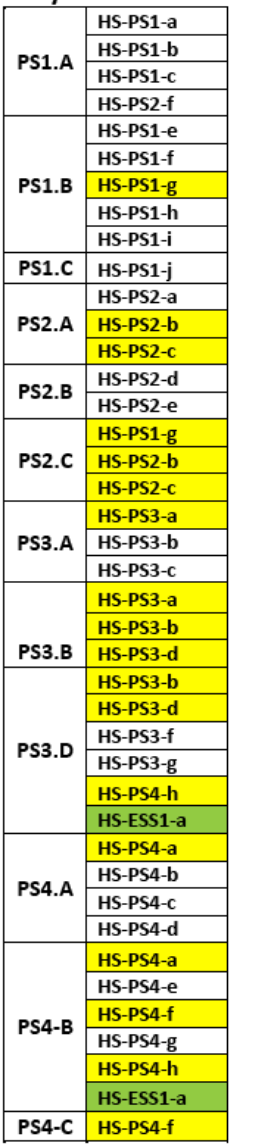

Earth and Space Science

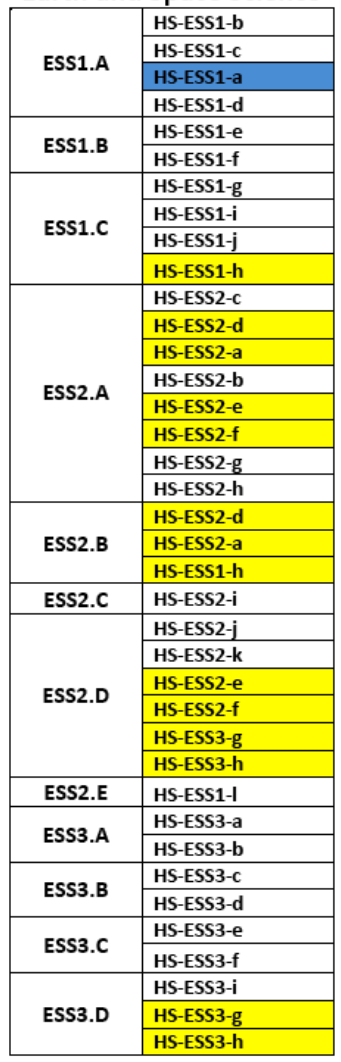

KEY

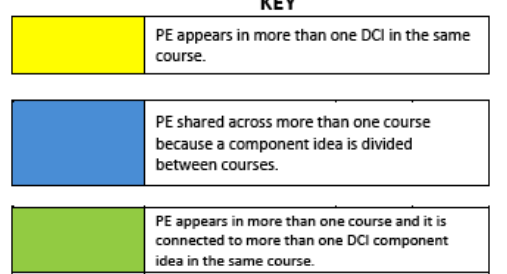




\section{Constructing NGSS-designed Instructional Materials}

\section{Appendix K -- Course Map \#1: Conceptual Understanding Model}

$$
\text { INTEGRATED SCIENCE MODEL }
$$

Course 1

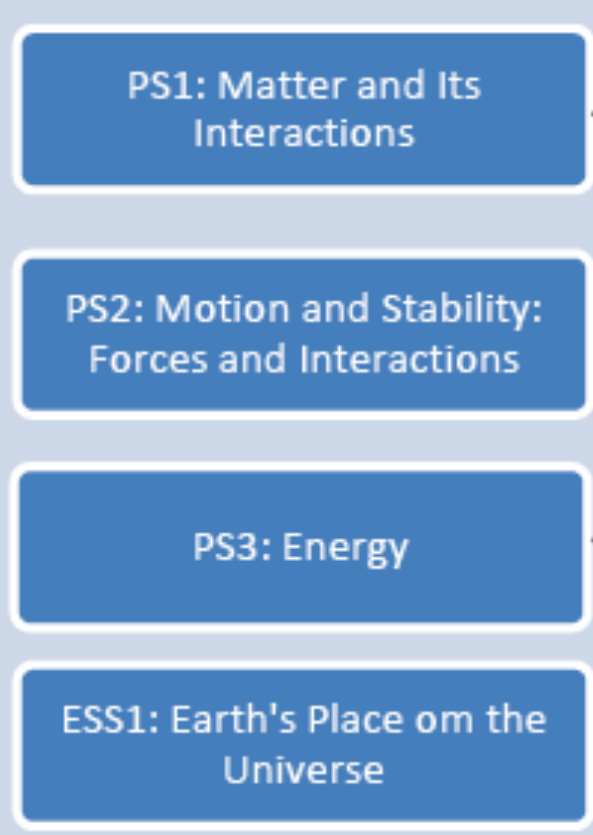

Course 2

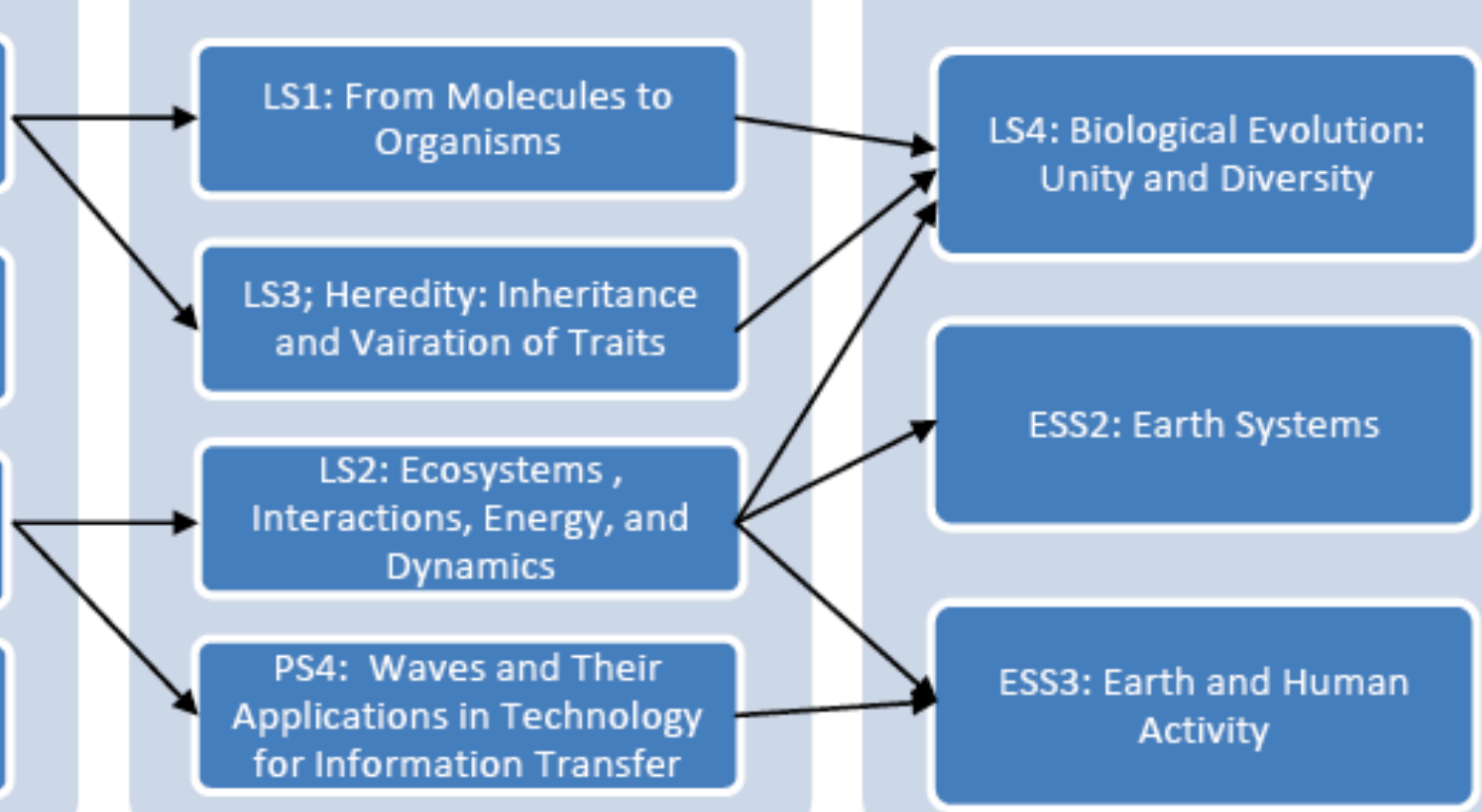




\section{Constructing NGSS-designed Instructional Materials}

\section{Appendix K -- Course Map \#1: Conceptual Understanding Model}

PHYSICAL SCIENCE

Course 2

Course 3
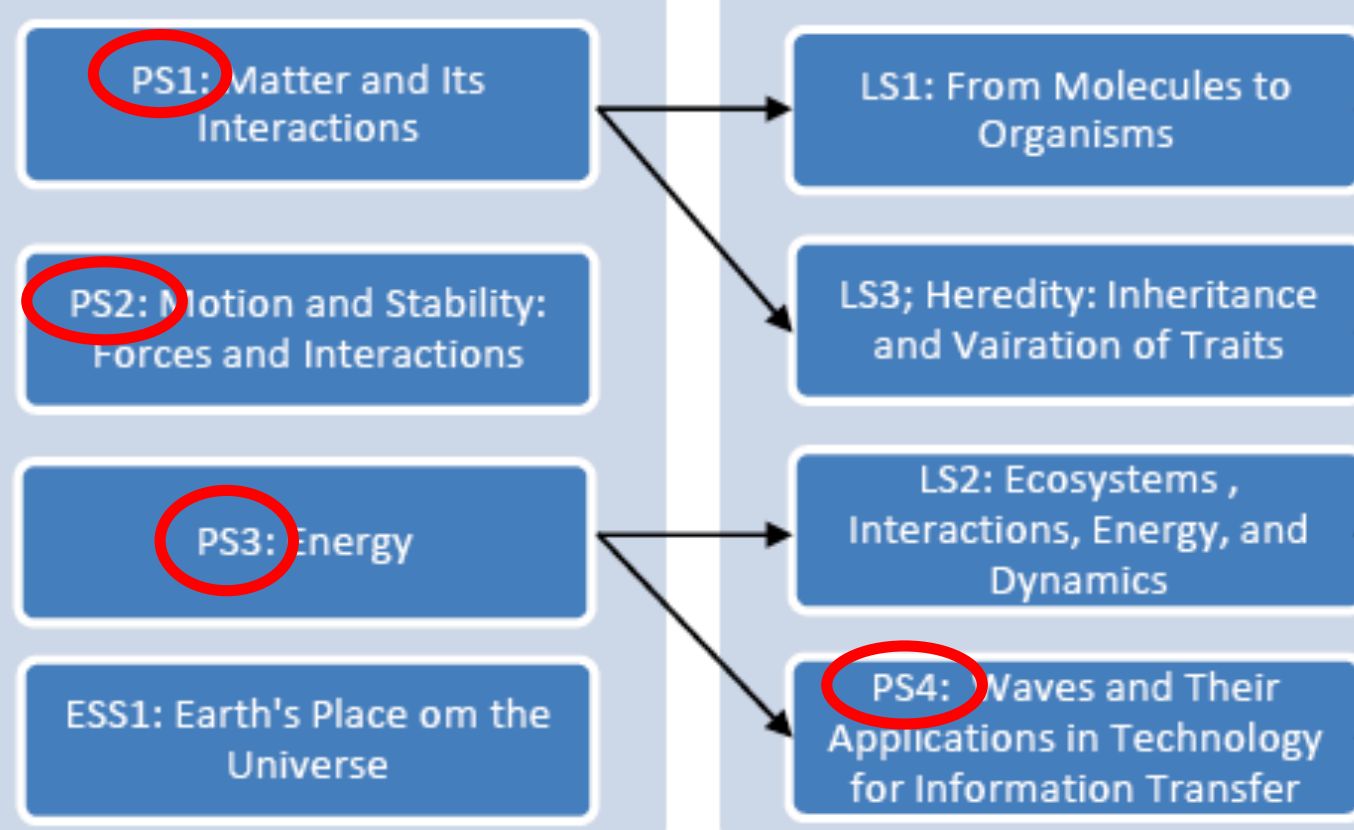

LS2: Ecosystems,

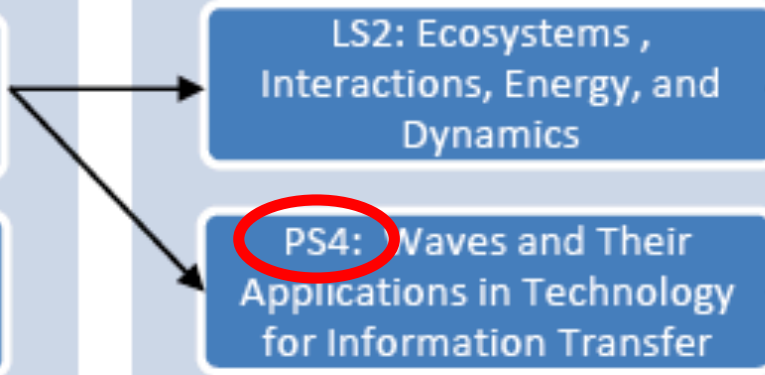

ESS2: Earth Systems

S4: Biological Evolution:

Unity and Diversity

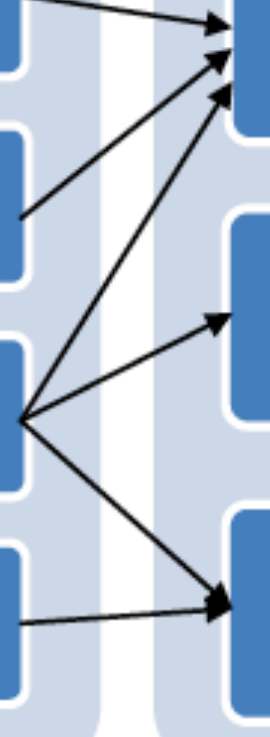

ESS3: Earth and Human Activity 


\section{Constructing NGSS-designed Instructional Materials}

\section{Appendix K -- Course Map \#1: Conceptual Understanding Model}

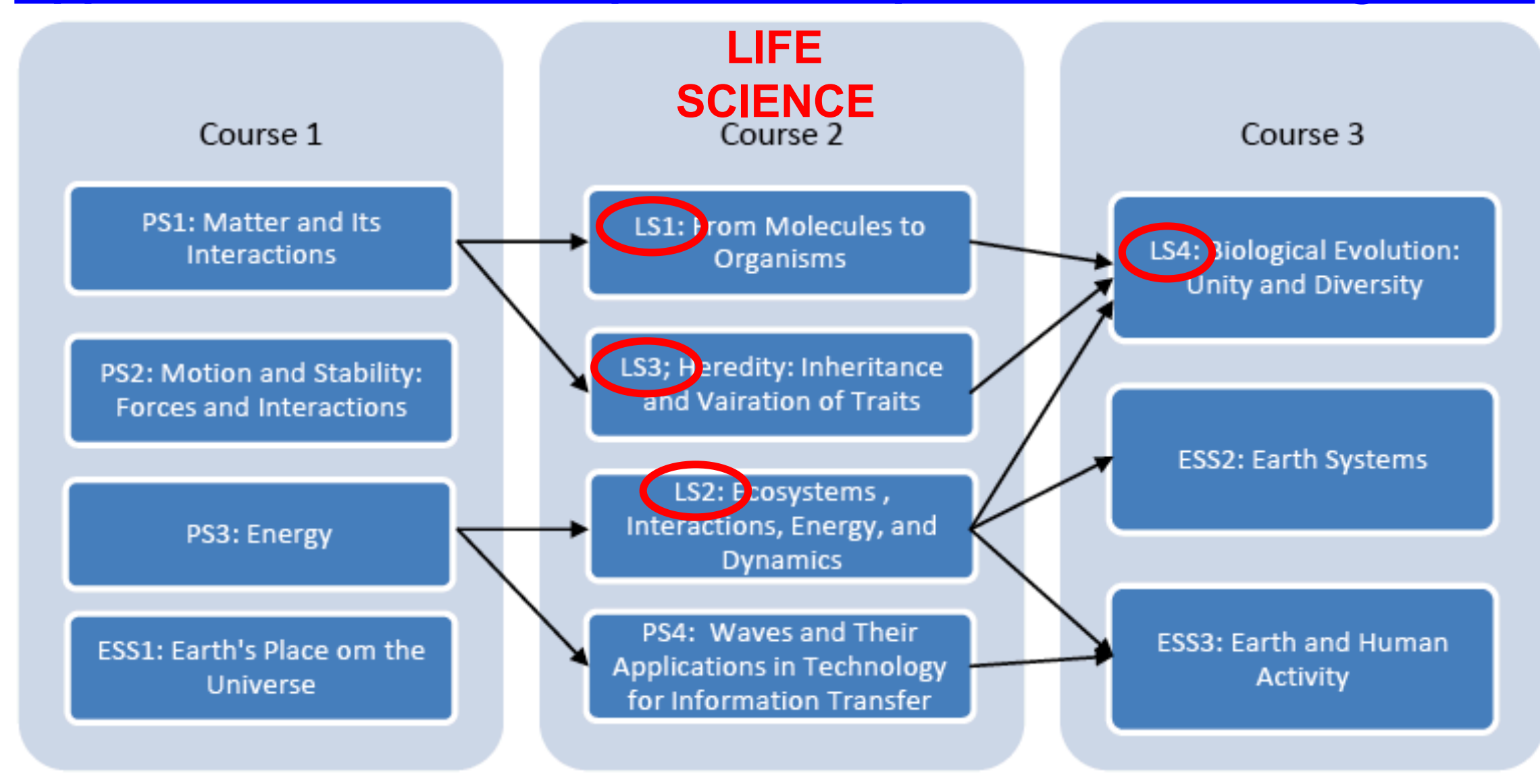




\section{Constructing NGSS-designed Instructional Materials}

\section{Appendix K -- Course Map \#1: Conceptual Understanding Model}

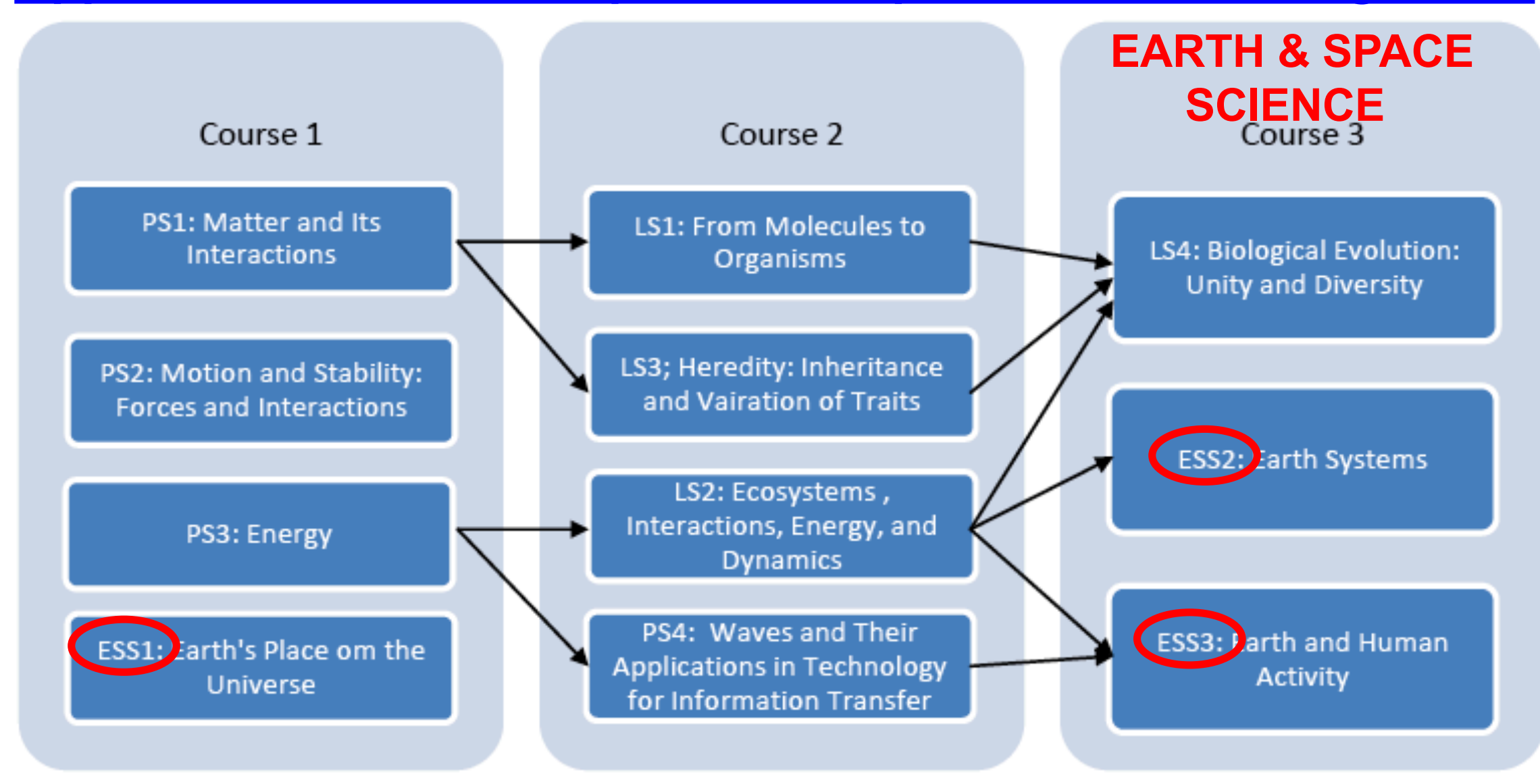




\section{Bundling the NGSS}

Example Bundles:

Read First: Introduction and Guide

\section{Kindergarten}

Thematic Model

Topics Model

1st Grade

Thematic Model

Topics Model

2nd Grade

Thematic Model

Topics Model

3rd Grade

Thematic Model

Topics Mode

4th Grade

Thematic Model

Topics Model

5th Grade

Thematic Model

Topics Model

\section{Middle School}

Course 1: Phenomenon Model

Course 2: Phenomenon Model

Course 3: Phenomenon Model

Course 1: Topics Model

Course 2: Topics Model

Course 3: Topics Model

\section{High School}

Course 1: Conceptual Progressions Model

Course 2: Conceptual Progressions Model

Course 3: Conceptual Progressions Model

Course 1: Modified Domains Model: Chemistry w/Earth and Space Science

Course 2: Modified Domains Model: Physics w/Earth and Space Science

Course 3: Modified Domains Model: Biology w/Earth and Space Science 


\begin{tabular}{|c|c|c|c|}
\hline & A & C & \multirow{8}{*}{$\begin{array}{l}\text { ELEVATE } \\
\text { SCIENCE } \\
\text { Table of } \\
\text { Contents }\end{array}$} \\
\hline 1 & \multicolumn{2}{|c|}{ MIDDLE GRADES NATIONAL "ELEVATE" } & \\
\hline 2 & & Chemistry & \\
\hline 3 & & Physics & \\
\hline 4 & & Biology & \\
\hline 5 & & Earth Science & \\
\hline 6 & & Space science & \\
\hline 7 & & & \\
\hline 8 & 6th Grade & 7th Grade & 8th Grade \\
\hline 9 & 6.1 - Intro to Matter & 7.1 - The Cell System & 8.1 - Atoms and Per Table \\
\hline 10 & 6.2 - Solids, Liquids, Gases & 7.2 - Human Body Sys & 8.2 - Chemical Reactions \\
\hline 11 & 6.3 - Energy & 7.3 - Repro and Growth & 8.3 - Forces \& Motion \\
\hline 12 & 6.4 - Thermal Energy & 7.4 - Ecosystems & 8.4 - Genes \& Heredity \\
\hline 13 & 6.5 - Earth's Systems & 7.5 - Populations/Comm & 8.5 - Natural Selection \\
\hline 14 & 6.6 - Weather/Atmos & 7.6 - Natural Resources & 8.6 - History of Earth \\
\hline 15 & 6.7-Mins/Rocks/Geosph & 7.7 - Human Impacts & 8.7 - Atmosphere \& Ocean \\
\hline 16 & 6.8 - Plate Tectonics & 7.8 - Waves and EM Rad & 8.8 - Climate \\
\hline 17 & 6.9 - Earth's Surface Sys & $7.9-E \& M$ & 8.9 - Earth/Sun/Moon \\
\hline 18 & 6.10 - Liv Things/Biosph & 7.10 - Infor Technology & 8.10 - Sol System \& Univ \\
\hline 19 & & & \\
\hline
\end{tabular}




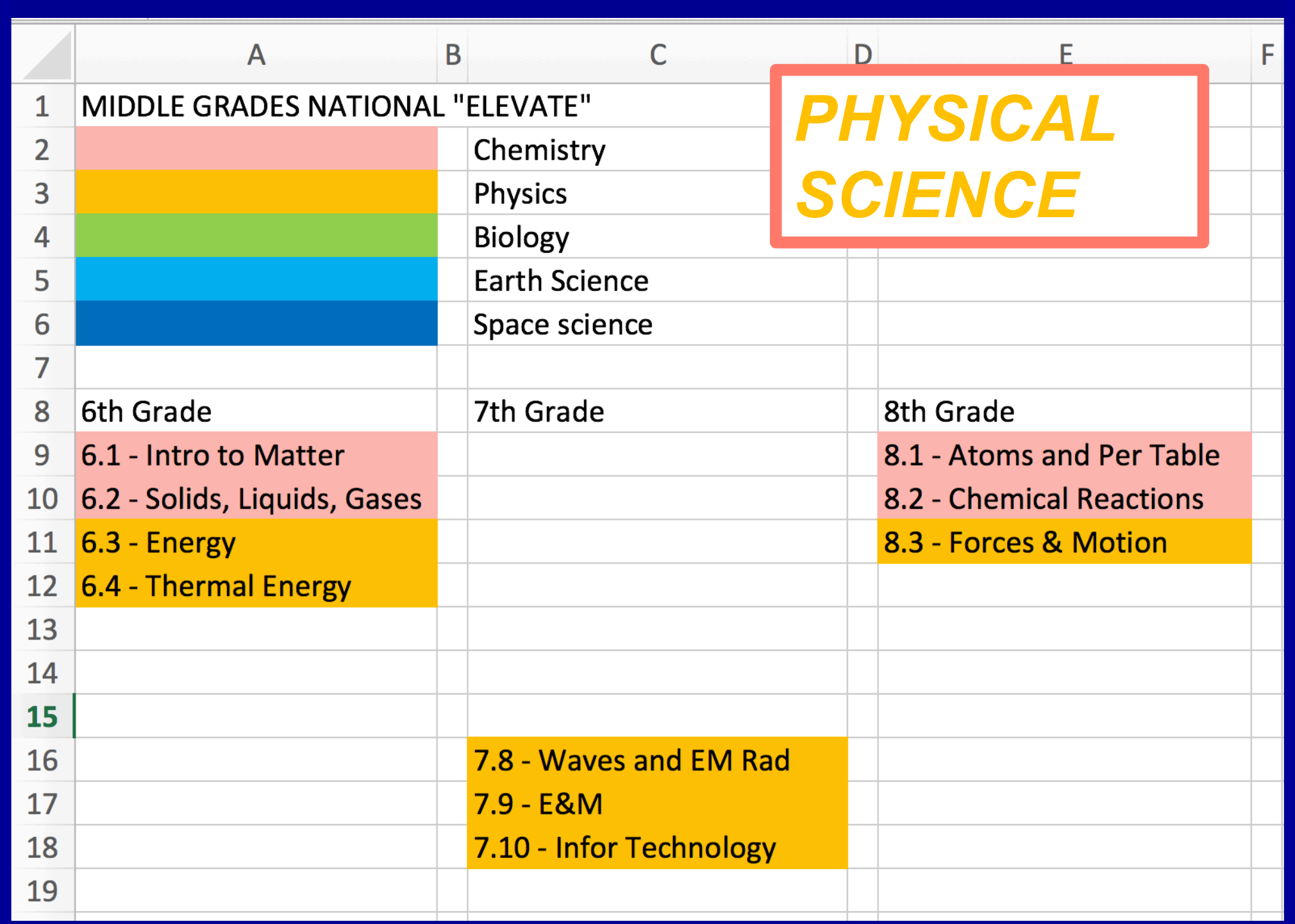




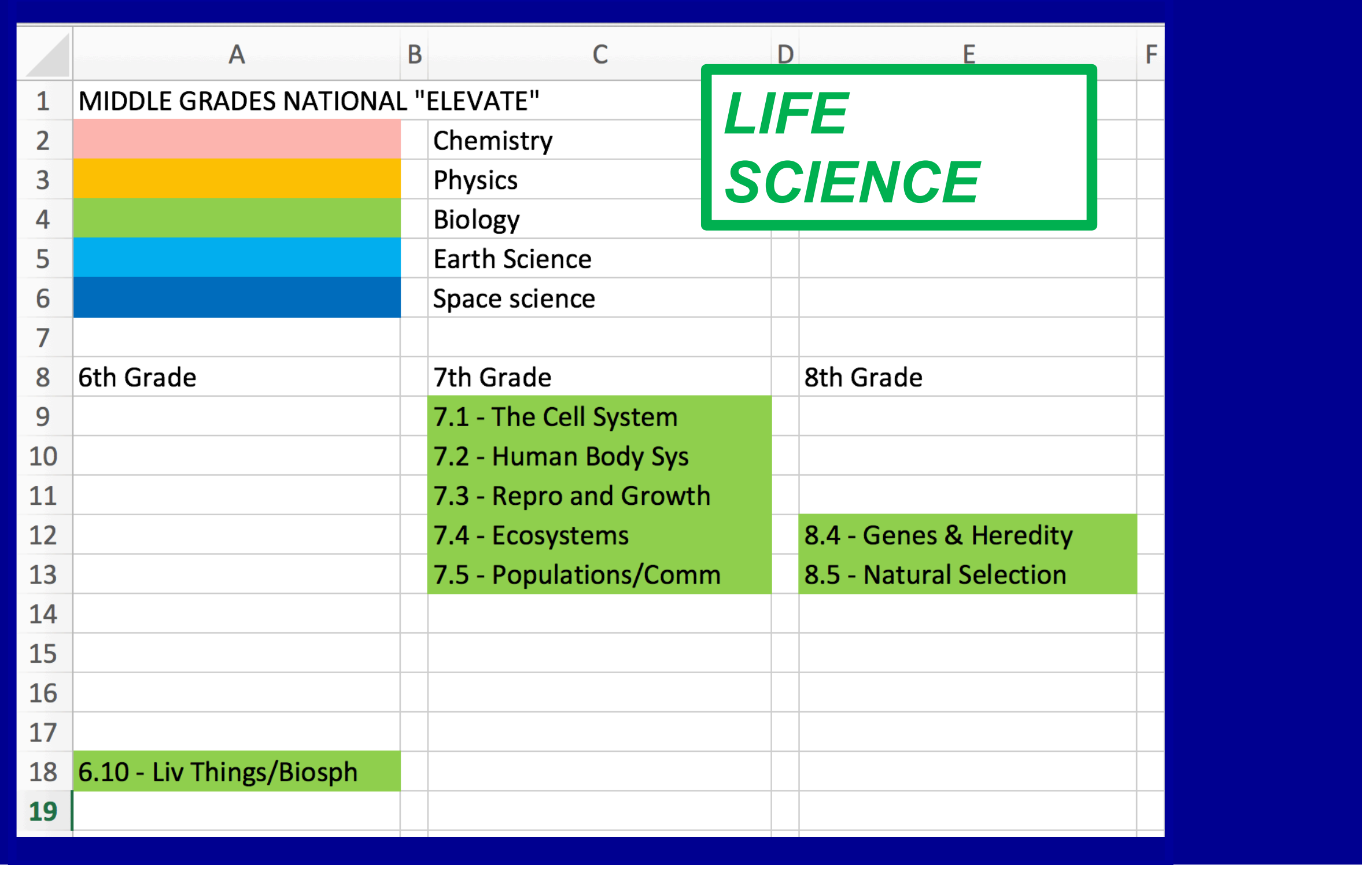




\begin{tabular}{|c|c|c|c|}
\hline & A & C & 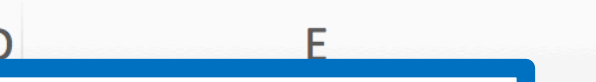 \\
\hline 1 & \multicolumn{2}{|c|}{ MIDDLE GRADES NATIONAL "ELEVATE" } & \\
\hline 2 & & Chemistry & \\
\hline 3 & & Physics & \\
\hline 4 & & Biology & \\
\hline 5 & & Earth Science & \\
\hline 6 & & Space science & \\
\hline 7 & & & \\
\hline 8 & 6th Grade & 7th Grade & 8th Grade \\
\hline 9 & & & \\
\hline 10 & & & \\
\hline 11 & & & \\
\hline 12 & & & \\
\hline 13 & 6.5 - Earth's Systems & & \\
\hline 14 & 6.6 - Weather/Atmos & 7.6 - Natural Resources & 8.6 - History of Earth \\
\hline 15 & 6.7 - Mins/Rocks/Geosph & 7.7 - Human Impacts & 8.7 - Atmosphere \& Ocean \\
\hline 16 & 6.8 - Plate Tectonics & & 8.8 - Climate \\
\hline 17 & 6.9 - Earth's Surface Sys & & 8.9 - Earth/Sun/Moon \\
\hline 18 & & & 8.10 - Sol System \& Univ \\
\hline 19 & & & \\
\hline
\end{tabular}




\section{ELEVATE SCIENCE (Topic "Essential Questions")}

\begin{tabular}{|c|c|}
\hline Topics & Topic/Phenomenon-Based Questions \\
\hline 1) Properties of Matter & 1) How do you describe properties of matter? \\
\hline 2) Changes in Matter & 2) What evidence do we have that matter changes? \\
\hline 3) Earth's Systems & $\begin{array}{l}\text { 3) How can you model the interactions about Earth's } \\
\text { Systems? }\end{array}$ \\
\hline 4) Earth's Water & $\begin{array}{l}\text { 4) How much water can be found in different places on } \\
\text { Earth? }\end{array}$ \\
\hline $\begin{array}{l}\text { 5) Human Impacts on Earth's } \\
\text { Systems }\end{array}$ & $\begin{array}{l}\text { 5) How can science ideas help up protect Earth's } \\
\text { resources and environments }\end{array}$ \\
\hline 6) Solar System & 6) What is Earth's place in space? \\
\hline $\begin{array}{l}\text { 7) Movement of the Earth and } \\
\text { its Moon Around the Sun }\end{array}$ & $\begin{array}{l}\text { 7) How do patterns of light and shade change from day } \\
\text { to day and season to season? }\end{array}$ \\
\hline 8) Energy and Food & $\begin{array}{l}\text { 8) Where does food's energy come from and how is } \\
\text { food used? }\end{array}$ \\
\hline $\begin{array}{l}\text { 9) Matter and Energy in } \\
\text { Ecosystems }\end{array}$ & $\begin{array}{l}\text { 9) How can you model the interactions of living things in } \\
\text { an ecosystem? }\end{array}$ \\
\hline
\end{tabular}




\section{Elevate}

Topic 4

(Student Edition)

Lesson 2 Patterns of Earth's Features

Lesson 3 Rocks, Minerals, and Soi

Lesson 4 Weathering and Erosion
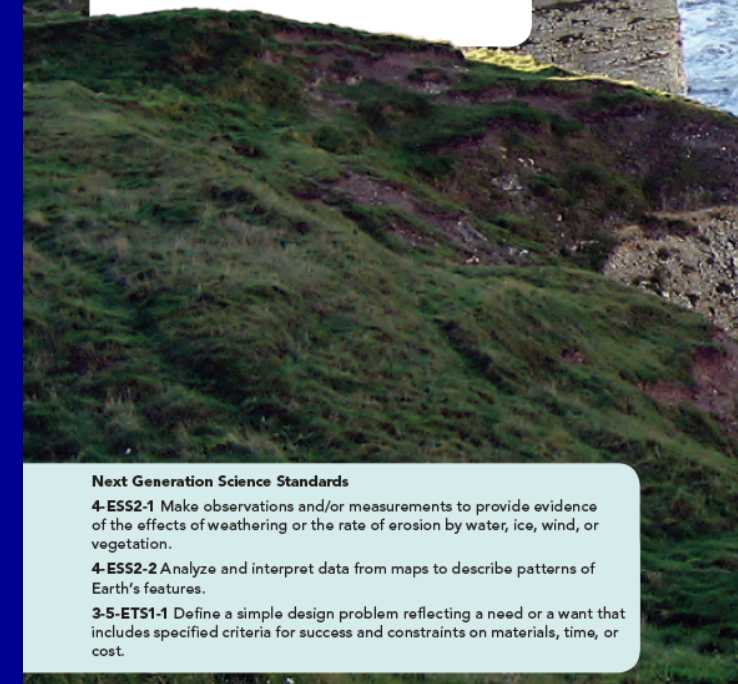

EThe
Ouential
Ouestion

(1) VIDEO

(1) eTEXT

(b) InTERActivity

([) VirTual LAB

(1) VIRTUal Lab

(8) ASSESSMENT
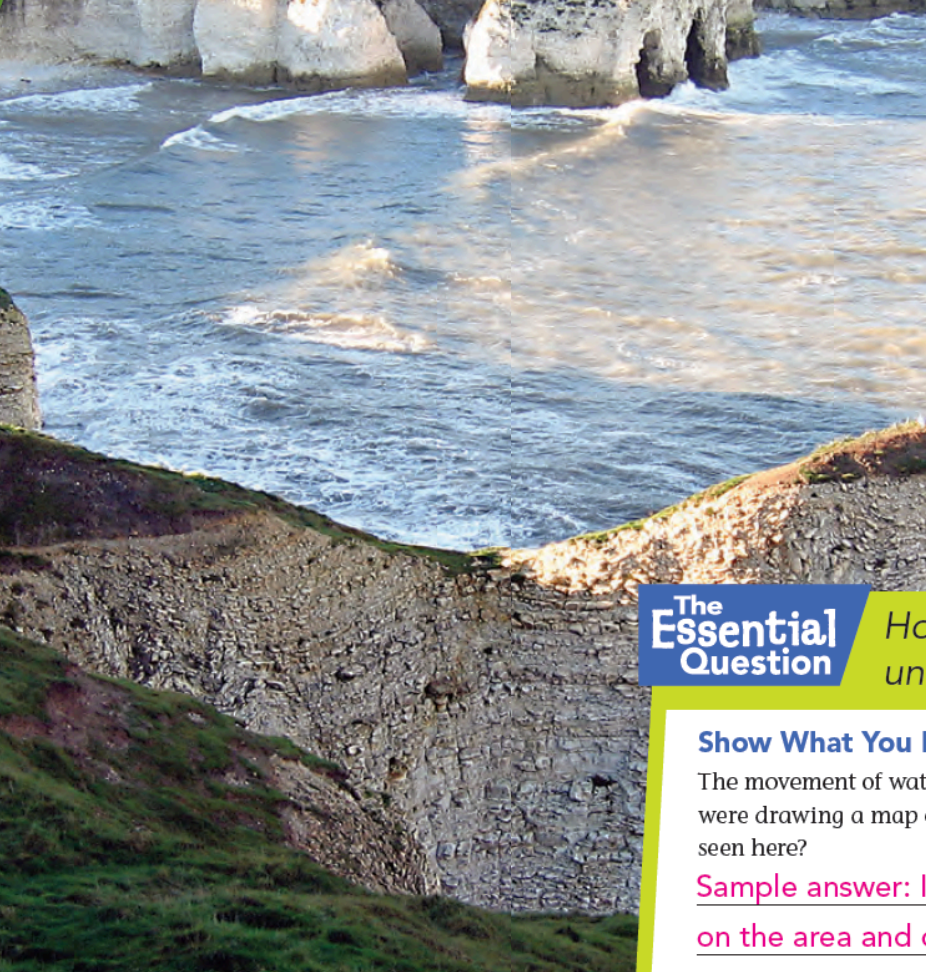

Show What You Know

The movement of water shapes landforms over millions of years. If you

were drawing a map of this area, how would you show the features

seen here?

Sample answer: I would draw a map looking down on the area and outline where the features are. 


\section{Elevate Science:}

Grade 4: Topic 4

\section{(Teacher Edition)}

\section{Topic 4}

Earth's Features

Storyline

Using Phenomena Students will come to the classroom having seen different landforms in their everyday lives. As your students progress through experiences to help them better understand how use observable events that occur in and around Earth's features, such as the events they see in photos and investigations in this topic. They will
use their science knowledge to explain or predict these observable events.

In this topic, students will learn to identify Indforms, rocks, and minerals. They will provide and change over time. They will examine and make maps to show important land features. They will also explore rocks, minerals, and soil. Students will learn about chemical and physical weathering, an Students will be introduced to science and engineering practices SEP. 3 and SEP. 4 by planning affects land, and analyzing and interpreting data
to observe how Earth's plates form land features. Key science vocabulary will be introduced thoughout the topic. Some vocabulary in this topic include legend, canyon, butte, fault, igneous, sediment

Students will also practice the important literacy atterns. They will use science content as a mean to practice this skill through the Reading Checks and Literacy Connection. Finally, students will practice the Cock standard MP.5 by using woo

Next Generation Sclence Standards 4ESS2-1 Make observations and/or measurements to
provide evidence of the effects of weathering or the rate of 4ESS2.2 Analyze and interpret data from maps to describe
patters of farth's features. 3.5.-ETS1-1 Define a simple design problem reflecting a
need or a want that includes specified criteria for success and 150 Topic 4 Earth's Features
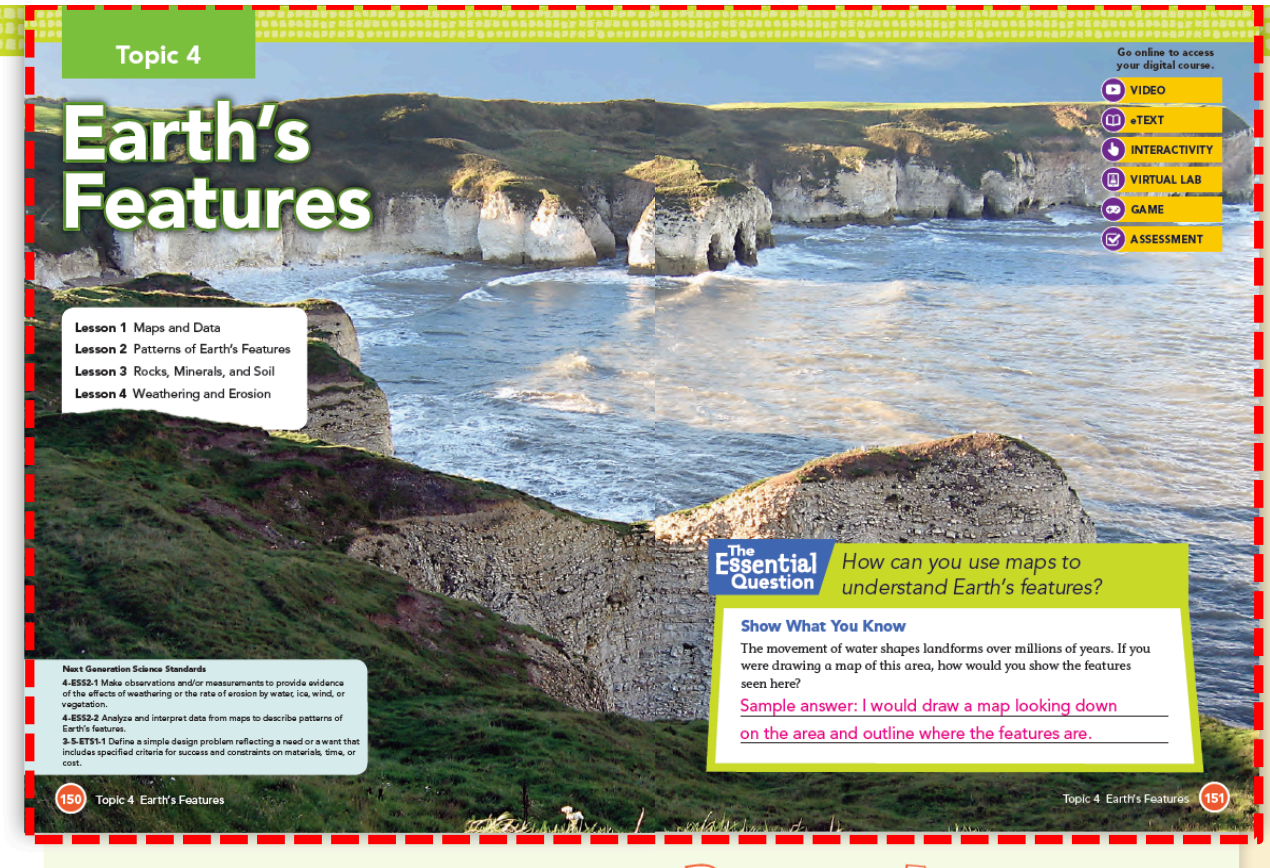

Topic Materials List

$\begin{array}{ll}\text { Consumable } & \text { Nonconsumable } \\ \text { - Bottom half of a gallon milk } & \text { - Graduated cylinder (15) } \\ - \text {. }\end{array}$ jug (15) Rectangular sponges (3)

- Sand (2 large bags)

- Soil (1 large bag)

- Paper plate (30)
Craft stick (30)

: Nail (15)

- White glue (15) - Rock samples (1 large bag)

- Water ( 5 gallons)

Sandstone sample $(1$ large

- bag)

- Limestone sample (1 large

- Chalk (15 pieces)
- Cardboard (15 sheets)

- Gravel (15 cups)
Differentiated Instruction

Support Struggling Students

Have students name the different features they see in the photo. Ask students how they might show the difference sheren we water and be shown on a map.

Support Advanced Learners

businesses in an area. Have them create a map that includes such structures, and write a brief summary, outlining the effect - Clear jar with lid (15) - Plastic spray bottle (15) - Plastic spray bottle *Materials listed per class
Encourage students to think about the impact of externa
VIDEo Watch a Professional Development Video to (1) -TEXT

The Student eTEXT lets students experience al

\section{(b) Interactivity}

The Synthesize Activity is a great way for learned.

\section{(b) interactivity}

The Engineering Activity is a great way for your students to think, plan, and design like engineers

(4) VIrTUal LAB

The Virtual Lab allows students to use different maps to choose the best location to place

\section{(9) game}

The MinI Games provide a fun way for students to practice what they have learned in the lesson.

\section{(2) ASSESSMENT}

The Topic Test is carefully built to check for deep understanding of key concepts. Remediation is
prescribed automatically to provide what students onstrate content mastery.

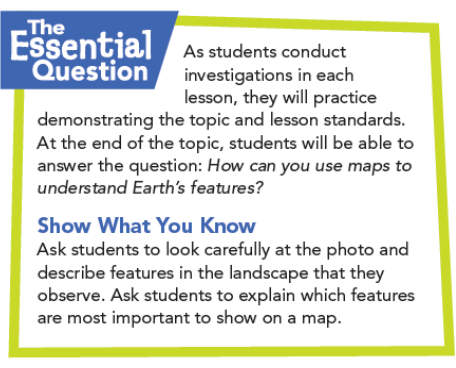




\section{Any NGSS-designed Curricular Materials Should Incorporate the Five "NGSS Innovations"}

1. Three-Dimensional Learning 


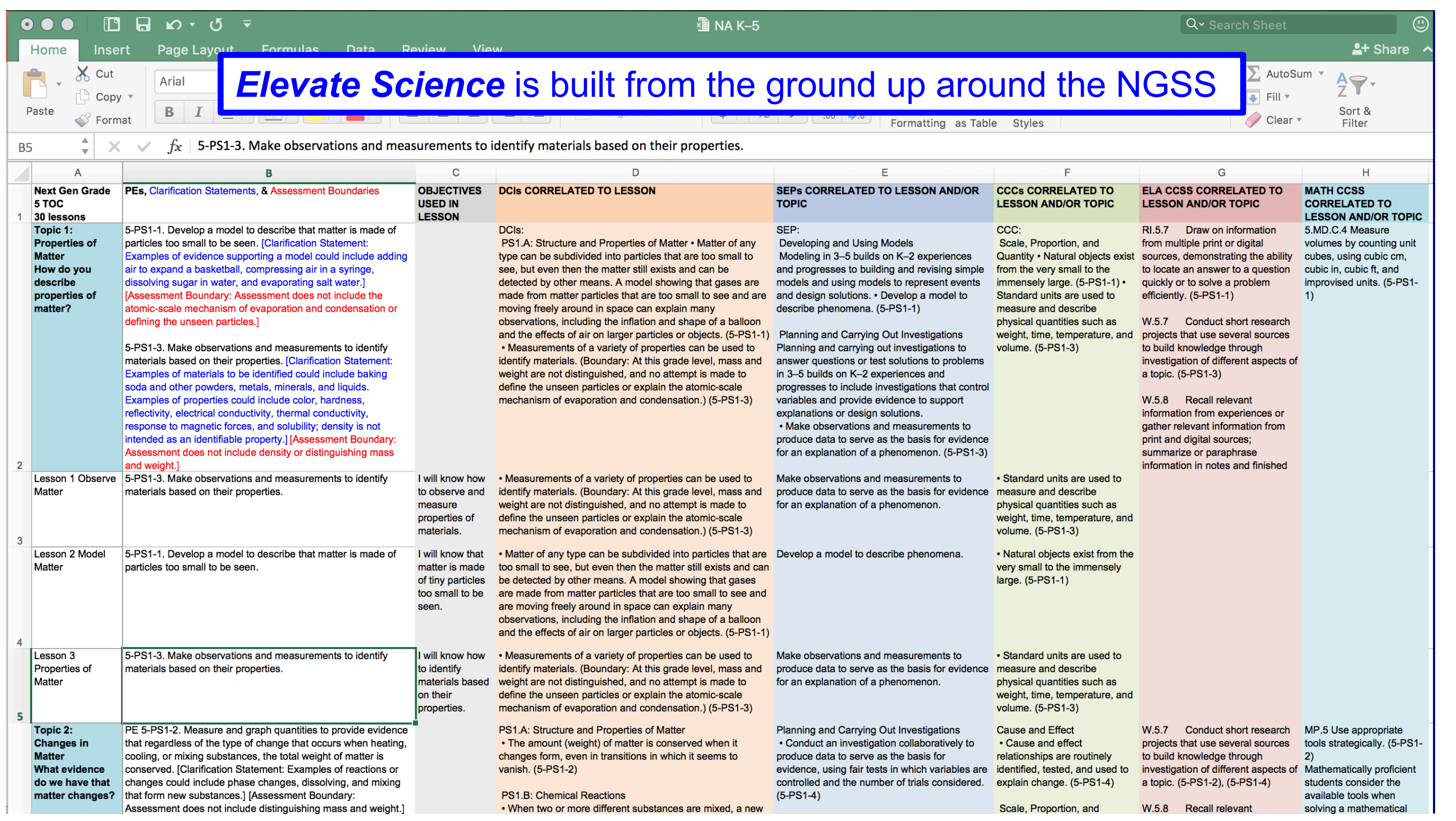




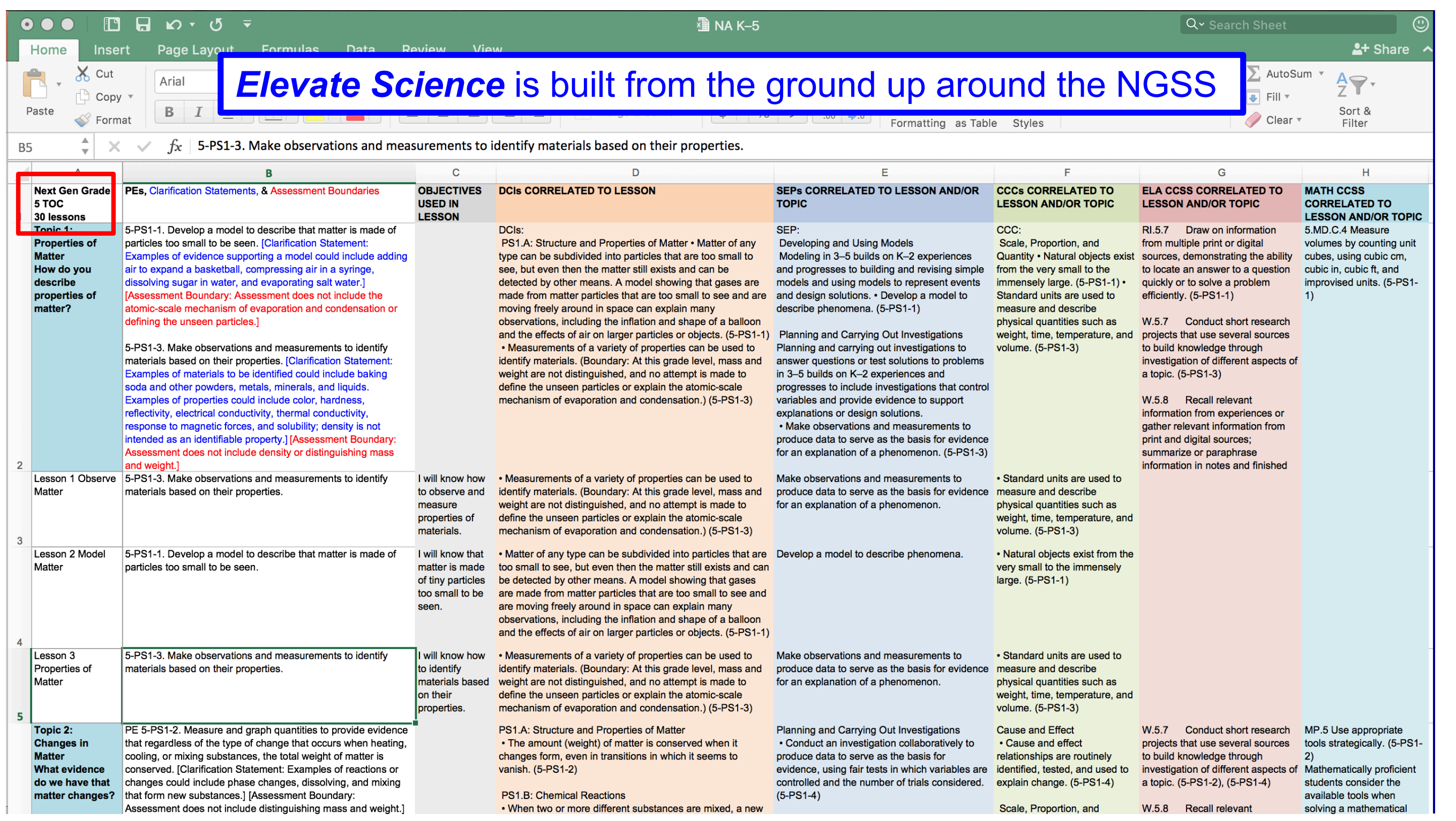




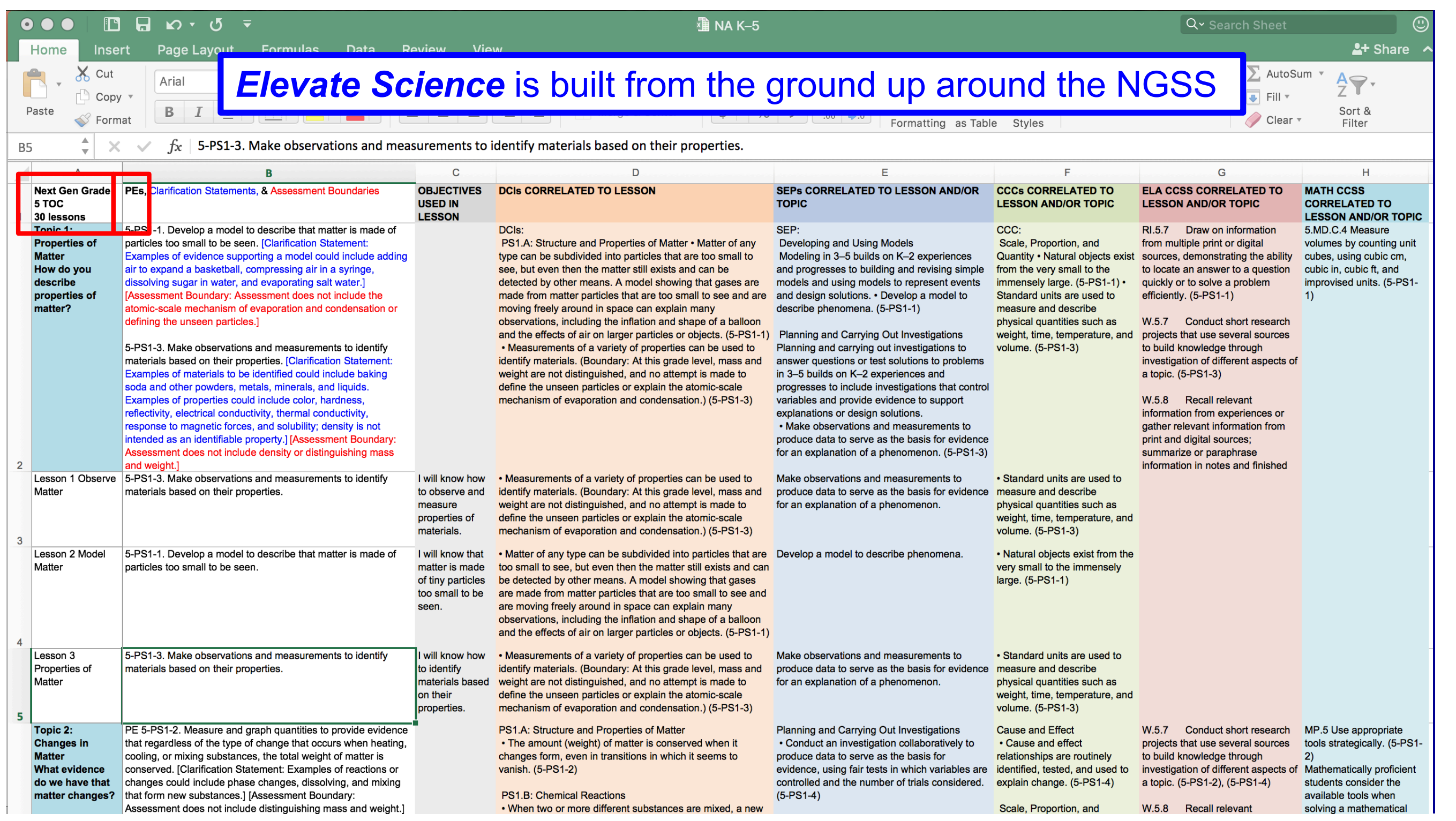




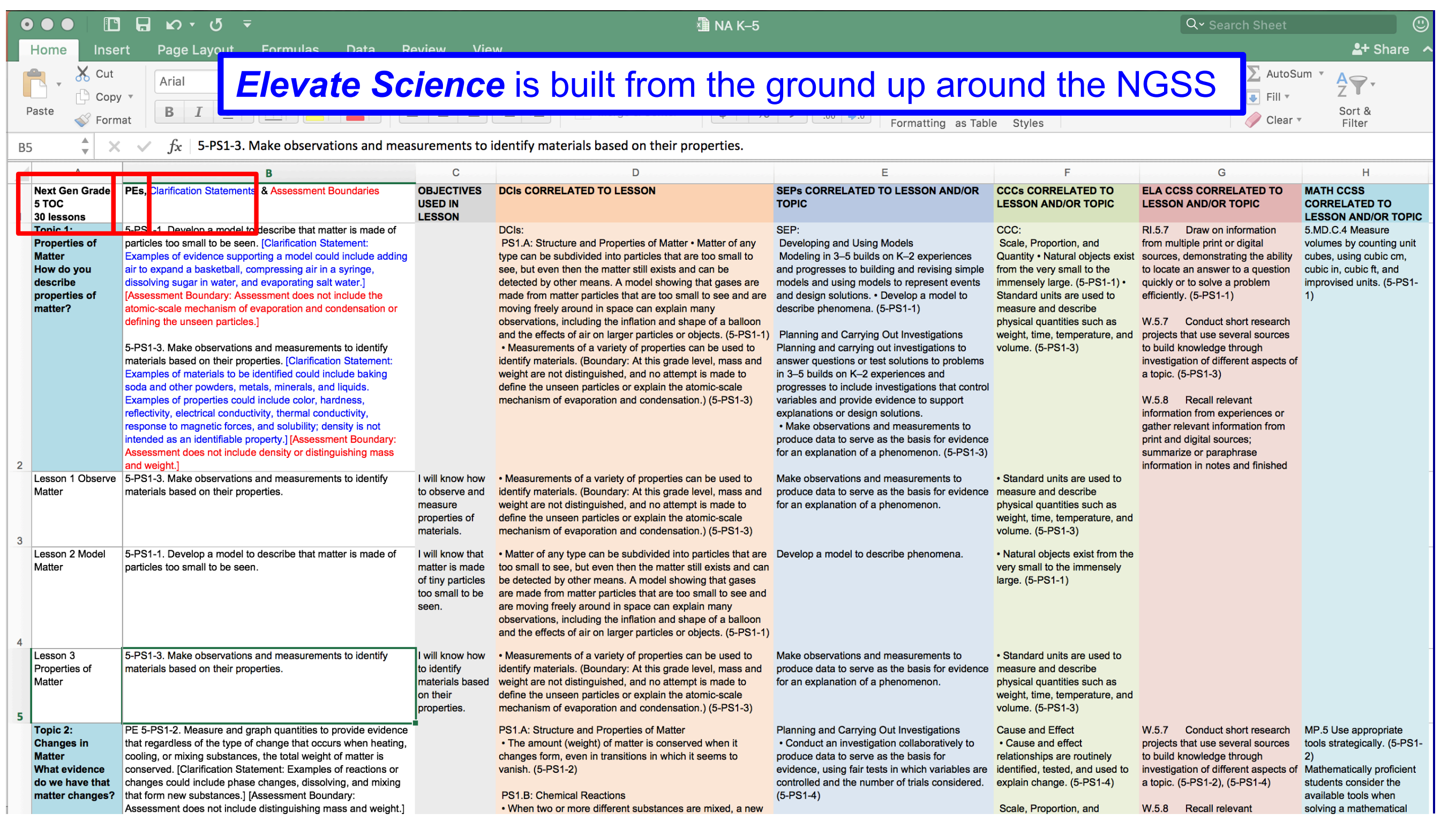




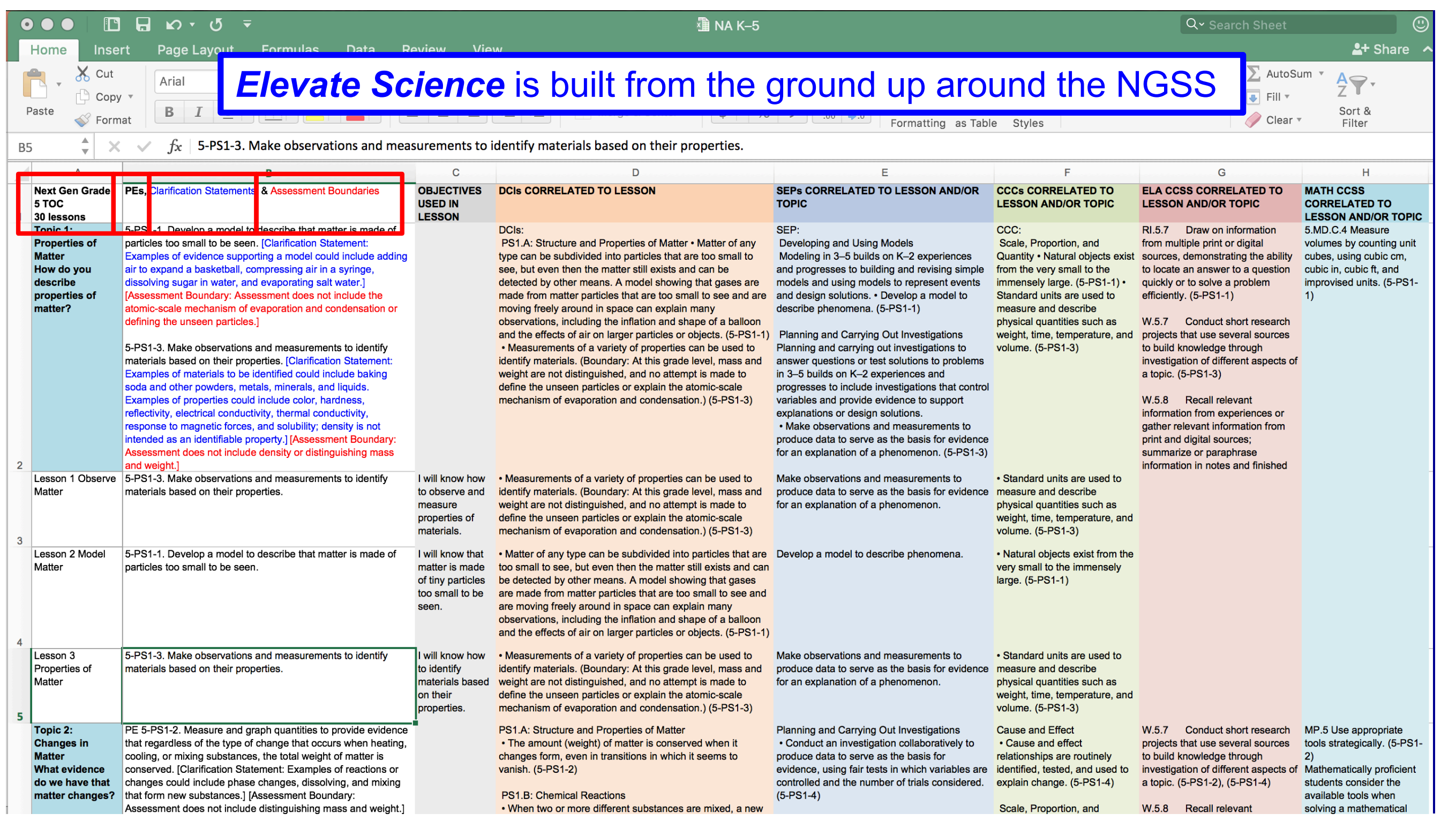




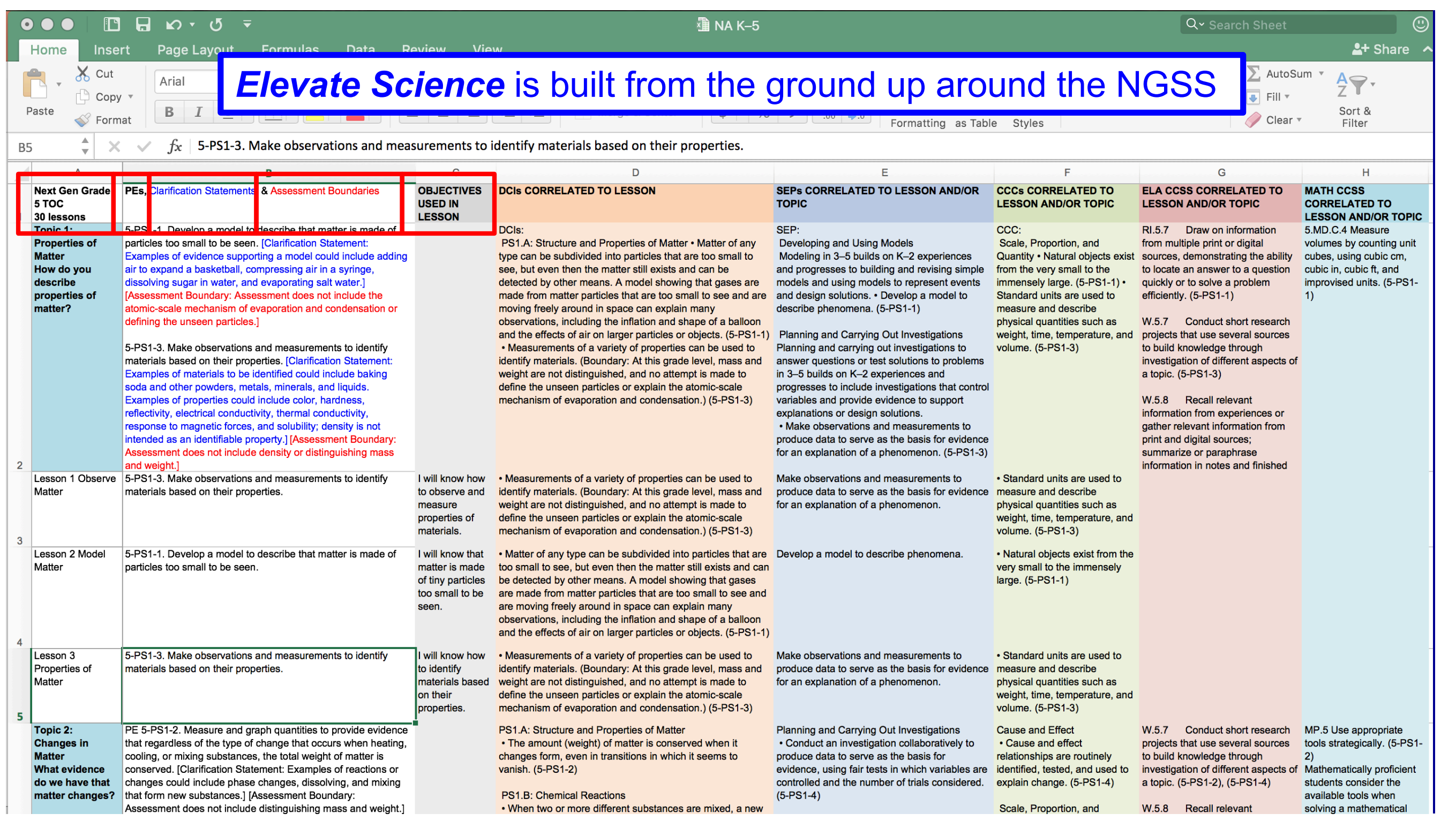




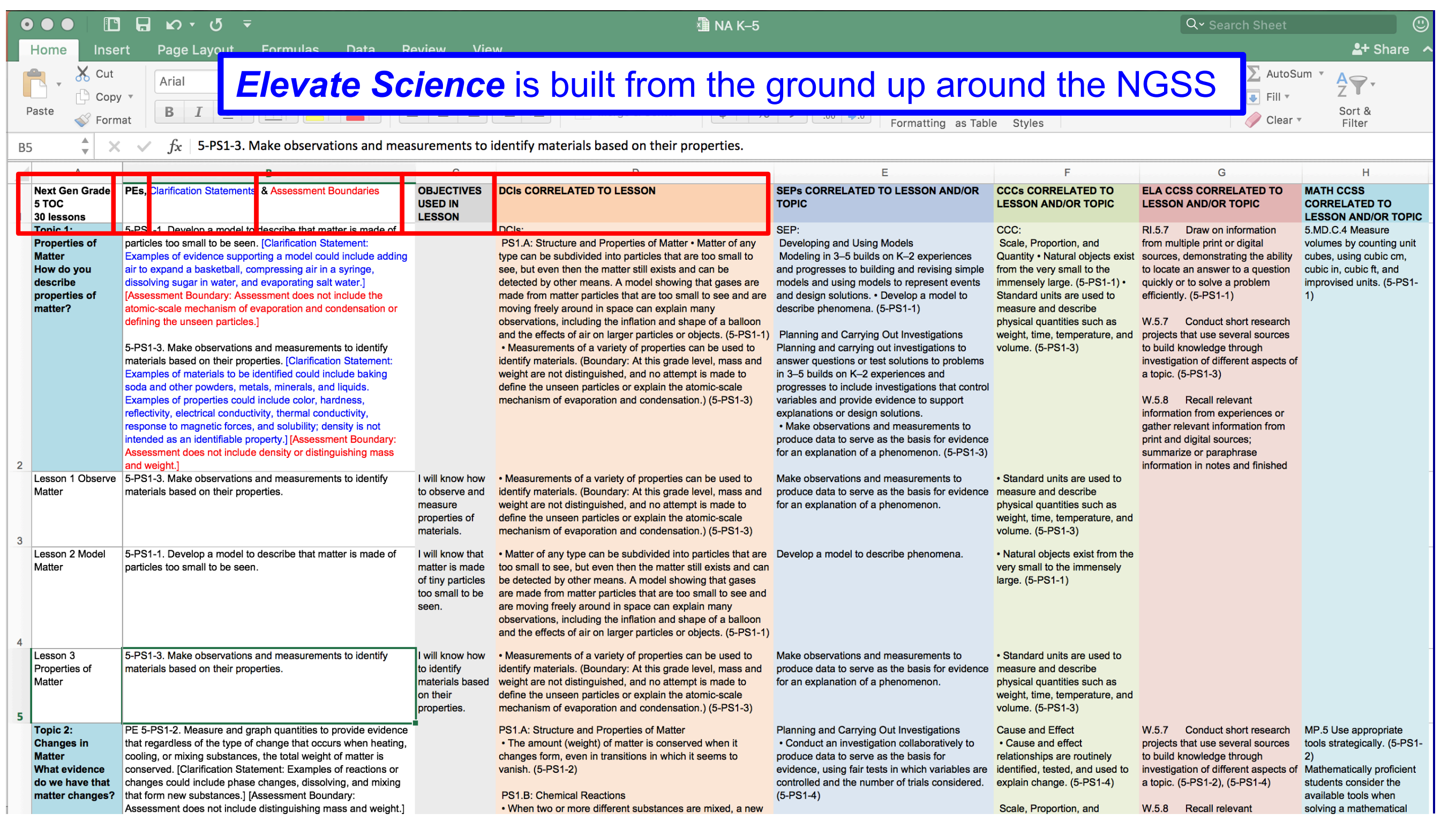




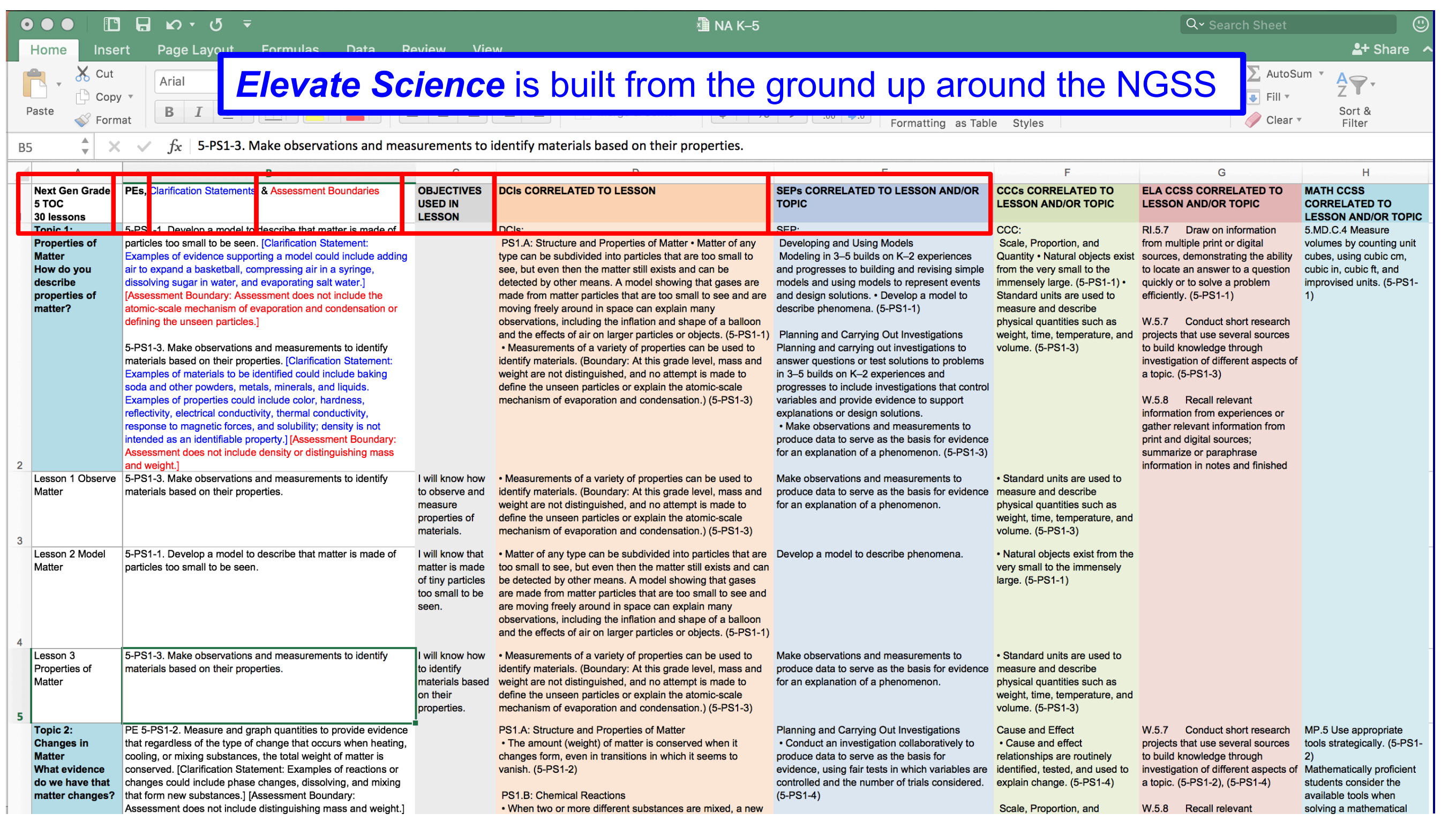




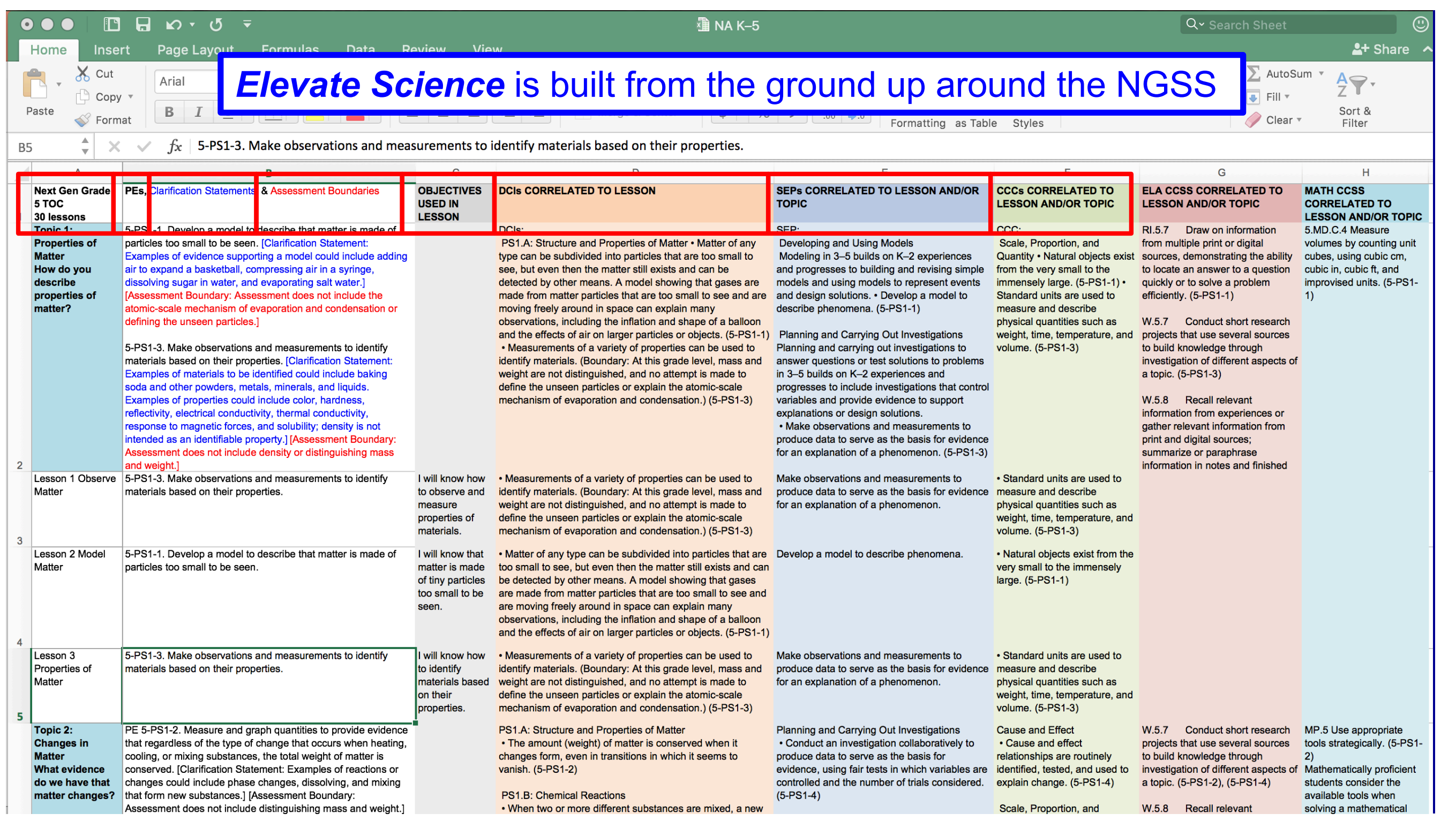




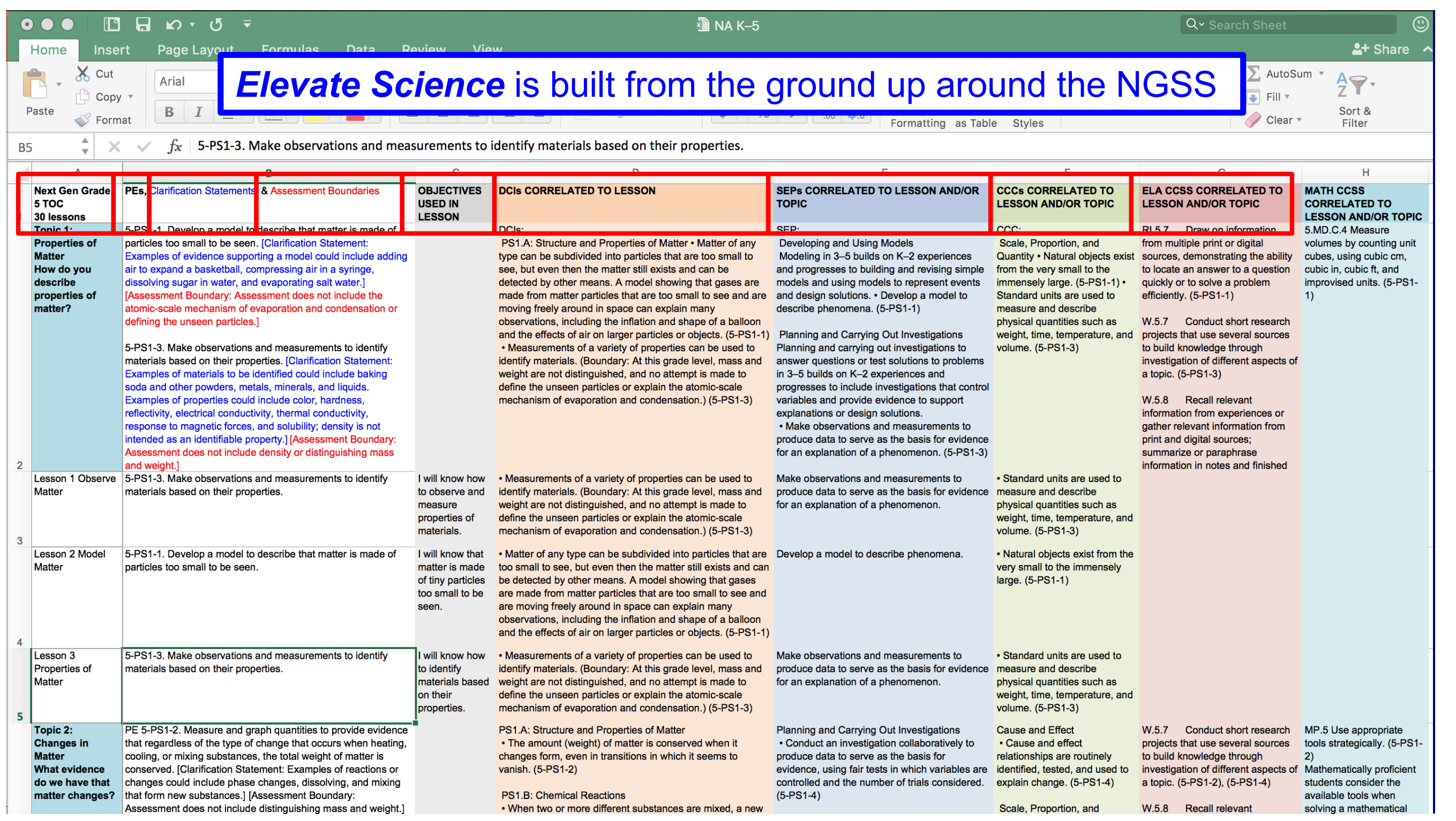




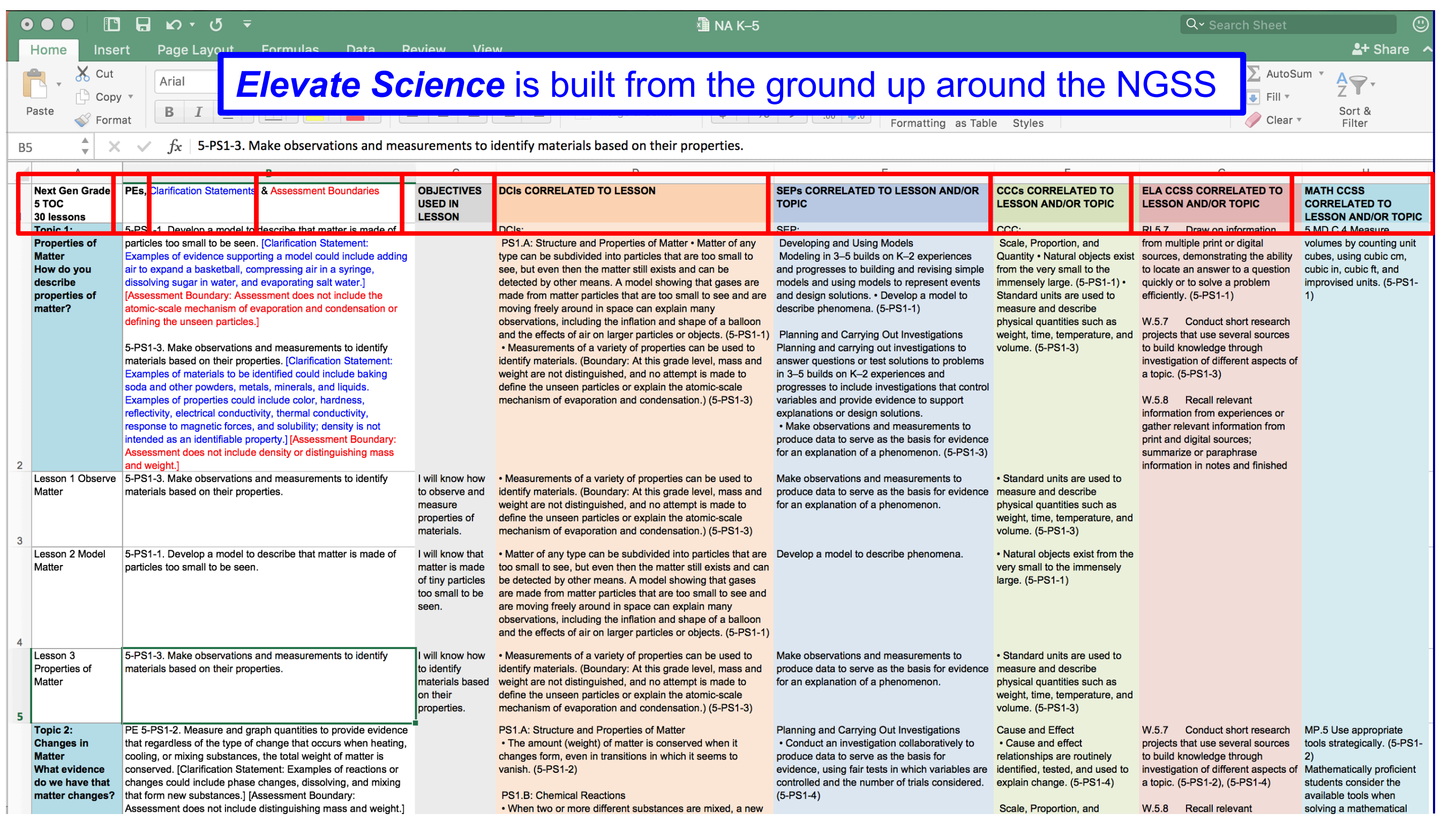




\section{Identifying Science and Engineering Practices:}

uConnect Lab

How can rain affect land?

Objective Students will make simple models to investigate the effect that rain has on landforms.

Time (30)

Grouping :

Understanding the Science Practice

Students will plan an investigation to determine how rain can affect land. In carrying how varying amounts of water can change the physical properties of their landform models. Connect this lab to the topic's uDemonstrate lab where students demonstrate mastery of

Materials Go online to download the master
material list, which also identifies kit materials.

Alternative Materials A foam cup with holes punched in the bottom can be used as a rain cup in place of the watering can.

Advance Preparation Pour the soil into plastic bins so that the students can easily measure it.

What to Expect Students should observe that the larger mounds will show less erosion than the smaller mounds. Also, students should conclude
that more rain results in more soil washing away.

国 Go online to the Lab Center to get editable

\section{Next Generation Science Standards and} Sclence and Engineering Practices

4ESS2.1 Make observations and/or measurements to
provide evidence of the effects of weathering or the rate of erosion by water, ce, wind a SEP.3 Planning and Carrying Out Investigations Make
observations and/or measurements to produce data to
serve as the basis for evidence for an explanation of a

phenomenon

154 Topic 4 Earth's Features
uConnect Lab

INMNOS-ON LAB

How can rain affect land?

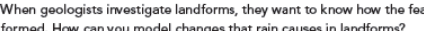

Procedure

1. How will different amouns d

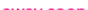

Q2. Set up your "land" in the milk ung. Carefully, turn each cur

of dirt.

$\square$ 3. Make a plan to test your prediction. Write your plan. Showit
to your teacher before you begin. Record your observations

- Analyze and Interpret Date

4. Uso Evidence How can rain affect
land Write your condusions besed on
the evidence from your investigation.

Sample answer: Rain washes

away soil. The more water

there is, the more soil gets

washed away. The smaller a

mound of soil is, the faster it

will wash away

(154) Topic 4 Earth's Features

\begin{tabular}{|c|c|c|}
\hline & $\begin{array}{l}\text { Water } \\
\text { amoum } 41\end{array}$ & $\begin{array}{l}\text { Water } \\
\text { amount \#2 }\end{array}$ \\
\hline $\begin{array}{l}\text { Small } \\
\text { mound }\end{array}$ & $\begin{array}{l}\text { Most of the } \\
\text { soil washed } \\
\text { away. }\end{array}$ & $\begin{array}{l}\text { All of the } \\
\text { soil washed } \\
\text { away. }\end{array}$ \\
\hline $\begin{array}{l}\text { Madium } \\
\text { mound }\end{array}$ & $\begin{array}{l}\text { Some of the } \\
\text { soil washed } \\
\text { away. }\end{array}$ & $\begin{array}{l}\text { Most of the } \\
\text { soil washed } \\
\text { away. }\end{array}$ \\
\hline 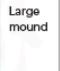 & $\begin{array}{l}\text { The mound } \\
\text { held water. }\end{array}$ & $\begin{array}{l}\text { More soil } \\
\text { washed } \\
\text { away. }\end{array}$ \\
\hline
\end{tabular}

\section{SGuiding Inquiry}

If your students need more direction on this lab, use the following procedure.

1. Fill $1 / 4$ cup with packed soil. Turn it upside down on the bottom half of the gallon $m$

. Make a second mound using $1 / 2$ cup of fimly packed sol.

3. Make a third mound using 1 cup of firmly packed soil.

4. Fill the graduated cylinder with $100 \mathrm{~mL}$ of water. Pour the water into a sprinkler can or spray bottle.

5. Evenly shake the rain over the three mounds. Record your observations in the chart.

6. Measure an additional $100 \mathrm{~mL}$ of water and repeat step 5 . Record your observations in the chart.

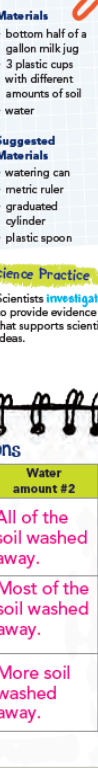




\section{Identifying}

Science and

\section{Engineering} Practices:
Added teacher support
uConnect Lab

How can rain affect land?

Objective Students will make simple models to investigate the effect that rain has on landforms.

Time (30) Grouping :

Understanding the Science Practice Students will pran an ninvestigation to out their investigation, students will study how varying amounts of water can change the physical properties of their landform models. Connect this lab to the topic's uDemonstrate lab where students demonstrate mastery of

Materials Go online to download the master material list, which also identifies kit materials.

Alternative Materials A foam cup with holes punched in the bottom can be used as a rain cup in place of the watering can. Advance Preparation Pour the soil into plastic
bins so that the students can easily measure it. What to Expect Students should observe that the larger mounds will show less erosion than the smaller mounds. Also, students should conclude

国 Go online to the Lab Center to get editable

154 Topic
uConnect Lalo

\section{How can rain affect land?}

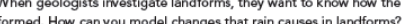

Procedure

1. How will different amounts of

Sample answe

Q2. Set up your "land" in the milk jug. Carefully, turn each cup

of dirt.

3. Make a plan to test your prediction. Write your plan. Show it
to your teacher before you begin Record your observations.

Analyze and Interpret Date

4. Uso Evidence How can rain affect
land Write yur condusions based on
the evidence from your investigation.

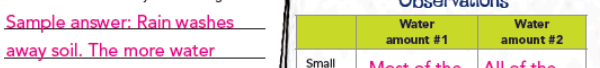

there is, the more soil gets

washed away. The smaller a

will wash away.

$\begin{array}{lll}\begin{array}{l}\text { Small } \\ \text { mound }\end{array} & \begin{array}{l}\text { Most of the } \\ \text { soil washed } \\ \text { awar. }\end{array} & \begin{array}{l}\text { All of the } \\ \text { soil washed }\end{array} \\ \end{array}$

\begin{tabular}{ll}
$\begin{array}{l}\text { soll washed } \\
\text { away. }\end{array}$ & $\begin{array}{l}\text { soll washed } \\
\text { away. }\end{array}$ \\
\hline
\end{tabular}

(154) Topic 4 Earth's features

me

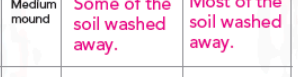

\section{sGuiding Inquiry}

If your students need more direction on this lab, use the following procedure.

1. Fill $1 / 4$ cup with packed soil. Turn it upside down on the bottom half of the gallon milk jug. Pack any loose soil together into a firm shape.

2. Make a second mound using $1 / 2$ cup of firmly packed soil.

3. Make a third mound using 1 cup of firmly packed soil.

4. Fill the graduated cylinder with $100 \mathrm{~mL}$ of water. Pour the water into a sprinkler can or spray bottle.

5. Evenly shake the rain over the three mounds. Record your observations in the chart.

6. Measure an additional $100 \mathrm{~mL}$ of water and repeat step 5 . Record your observations in the chart. 


\section{Identifying \\ Science and \\ Engineering Practices:}

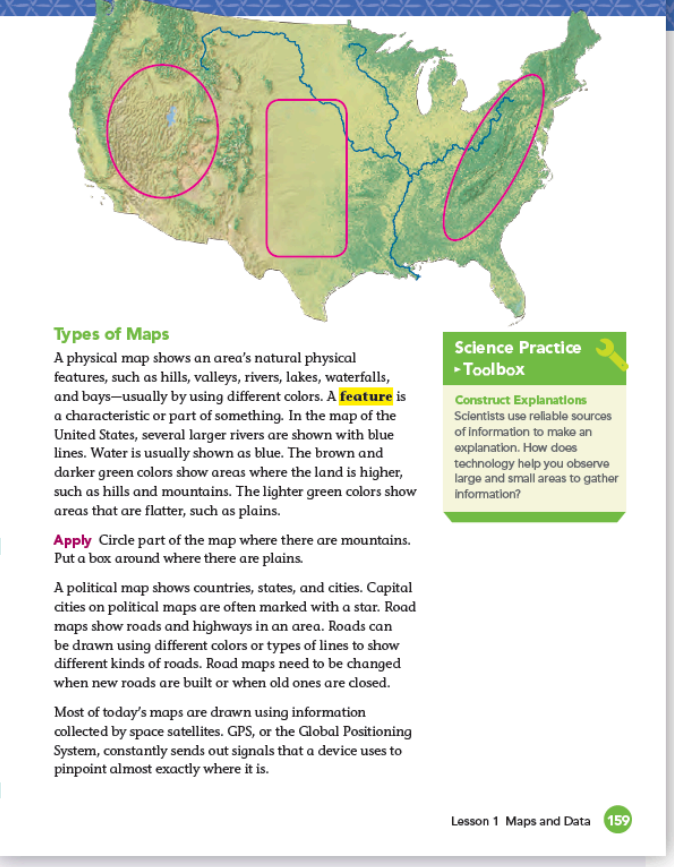

21 $1^{\text {st }}$ Century Skills

Interpersonal and Collaborative Skills

Maps are a great visual way to show information and learn

about various places. With the rise of satellite imagery and

data, maps have become an increasingly popular way of

helping people understand the changes in the world. It is now

much easier and faster to update data, and show how an area

engage in a discussion with peers regarding the importance

of using maps to show evidence of climate change, habitat

destruction, and population growth. Encourage students to

research samples of these types of maps using the Internet.

This activity uses the ELA Speaking and Listening skill of
Scaffolded Questions

Help students set a frame for reading by asking

guiding questions: Why are certain maps used for

specific purposes? What are these different maps

used for? Then, have them read the section Types

of Maps to find out if their answers were correct.

When they finish, use the following questions

to assess their Depth of Knowledge levels of
understanding.

List Name the different types of maps described

int

Interpret Determine what kind of map you
would use on a hiking trip. DOK2 (A physical

the around.) What part of the reacing provides

Dride Conlustons Consider ther

Draw Conclusions Consider the number of

satelltes in the sky and how it relates to the

in satellites have on the accuracy of maps? DOK

The maps would be less accurate because there

would be less data from the satellites to produce the maps.)

Science Practice - Toolbox

Construct Explanatlons Have students

list different sources they use to gather the

explanation to the question. Students may say

books, Internet resources, or daily activities.

Encourage students to share why using reliable

resources is very important when obtaining

and communicating scientific information. 


\section{Identifying}

Science and

Engineering Practices:

"Science

Practice

Toolbox

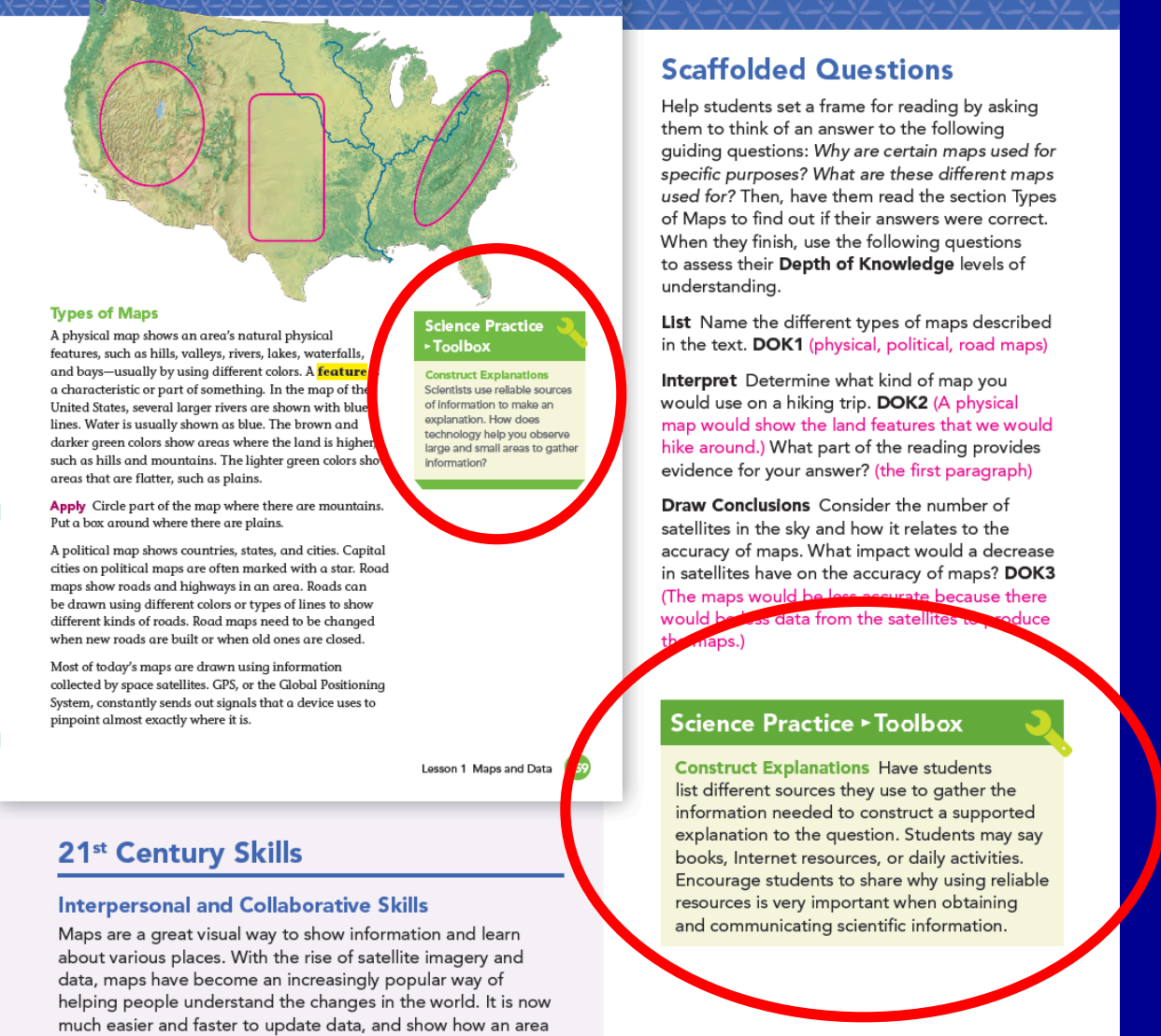

much easier and faster to update data, and show how an area

is changing due to natural and human factors. Have students

of using maps to show evidence of climate change, habitat

destruction, and population growth. Encourage students to

research samples of these types of maps using the Internet.

This activity uses the ELA Speaking and Listening skill of 


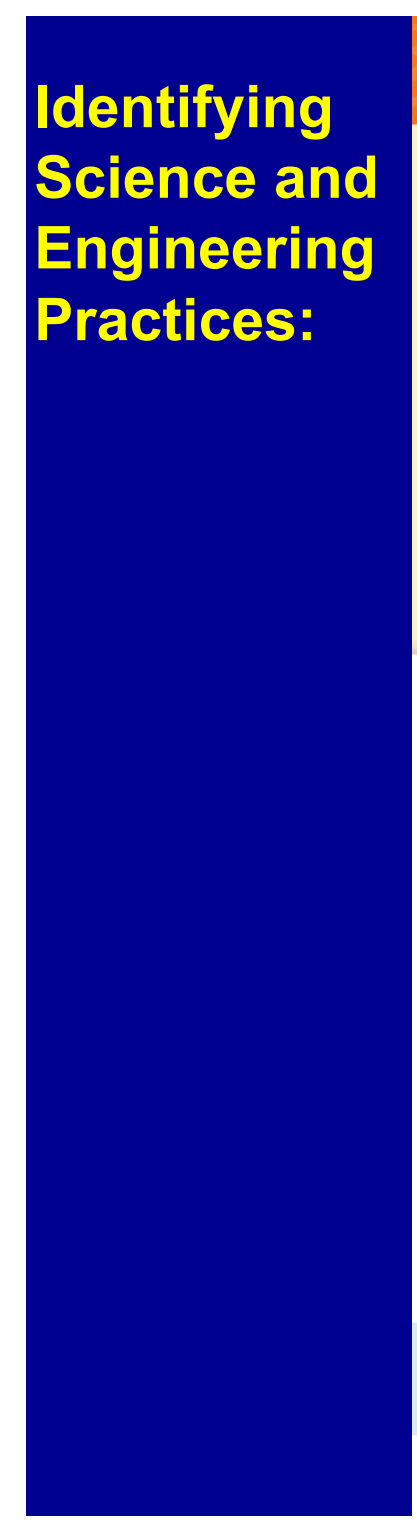

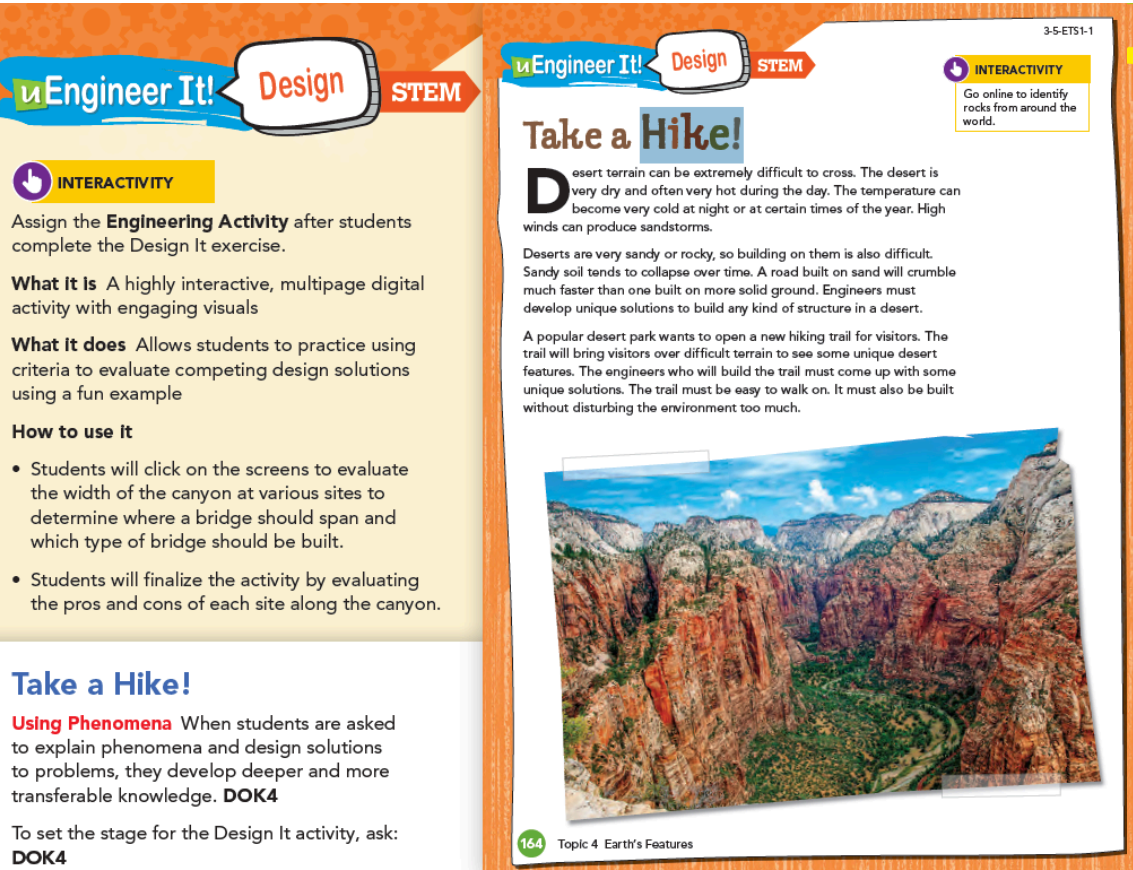

- What does the word criteria mean? (Guide

students to answer the question by asking if

"qual" sounds like a good definition for eeds to

What does the word constraint mean? (Guide students to answer the question by asking if definition for constraint.)

What are some characteristics of a desert that are important to keep in mind when building a trail? (Guide students to reference key points in the text, such as "The desert is very dry and
often very hot during the day," or "Deserts are very sandy or rocky, and sandy soil tends to

Next Generation Sclence Standards 3.5-ETS1-1 Define a simple design problem reflecting a
need or a want that includes specified criteria for success

164 Topic 4 Earth's Features

Engineering Design Process Define
Problem $\Rightarrow \begin{aligned} & \text { Develop } \\ & \text { Solutions }\end{aligned} \Rightarrow \begin{aligned} & \text { Optimize } \\ & \text { Solutions }\end{aligned}$

In the uEngineer It! activity, an engineering team at a desert explain the engineering design process to students. Start out by asking students to identify the problem. After students complete the activity, have them explain their designs. Suggest that students elaborate on why particular features of the trail Will help meet the criteria for success. To complete the design crafully about the practicality of their design in real life. Lead a brief class discussion about other ways they might need to modify or adjust their designs in order to make their designs practical.

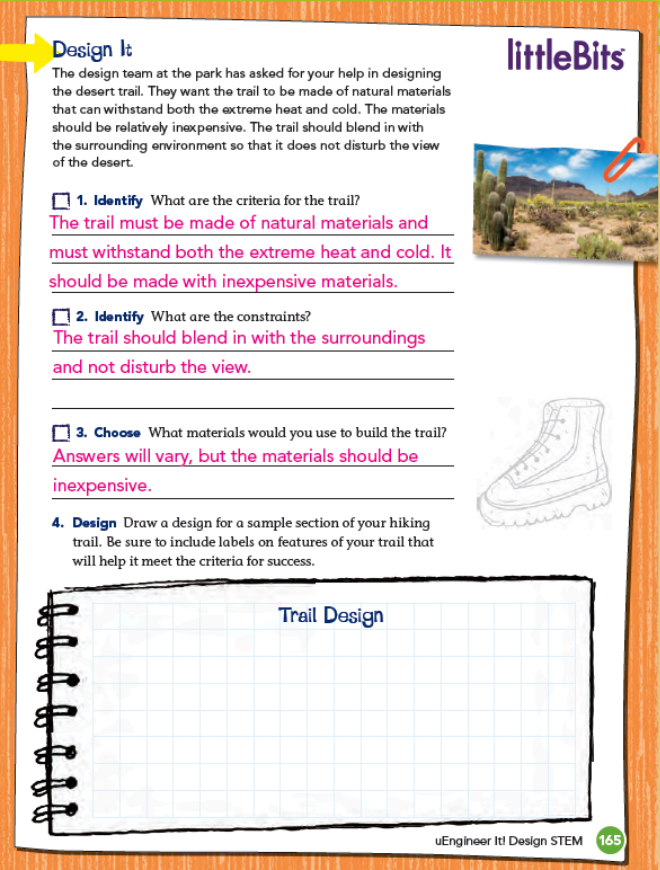

\section{Design It}

As students think about their design of the hiking trall, explain that drawings are often the first step revisit and revise their drawings when solving problems and developing solutions. In this task, have students consider real-life implications of their design

- Weather patterns vary in the desert. Heavy winds and dry air contribute to sandstorm which can lead to excess sand build-up

alongside trails that were once clear.

- There are many animal and plant species in the desert. Some desert animals protect themselves behaviors, such as biting, stinging, or even Students may want to consider how

\section{littleBits}

Go online to access your digital course for studen s and teacher support.

If your students enjoyed this activity, then encourage them to explore and investigate the challenges in their digital course. These evale opportunities allow students to design and their study of the engineering design process.

\section{Differentiated Instruction}

\section{Support Struggling Students}

Some students may need help identifying constraints and criteria for their trail. Read the passage with students. Have them highlight or underline important information that they together to list constraints and piteria

Support Advanced Learners

Have students select a new location for their hiking trail, such as the mountains or near the coast of an ocean. Ask them to write a brief summary describing which parts of their design 


Identifying
Science and
Engineering
Practices:
Added
support
on the
design
process

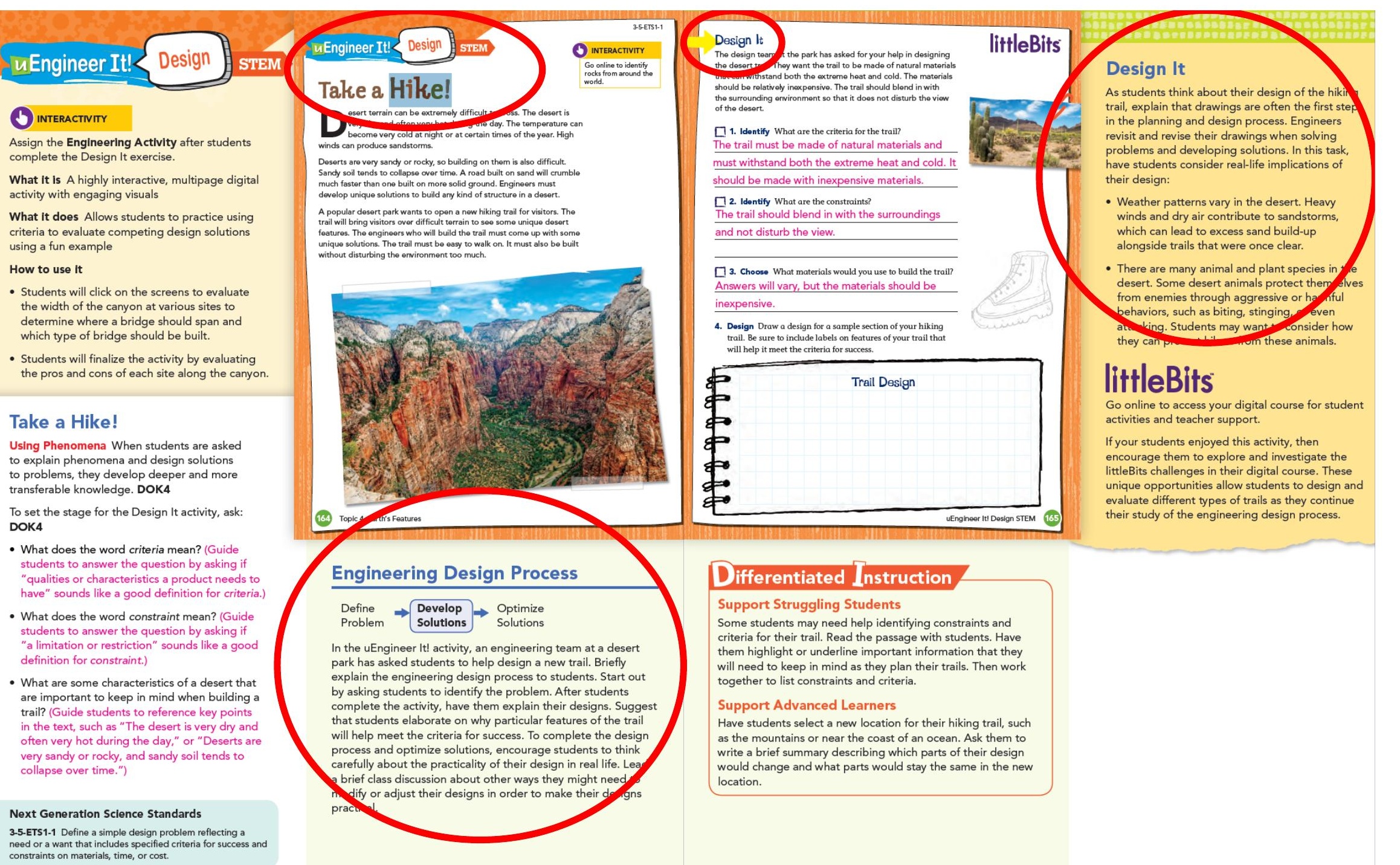

164 Topic 4 Earth's Features 


Identifying
Science and
Engineering
Practices:
Added
support
on the
design
process

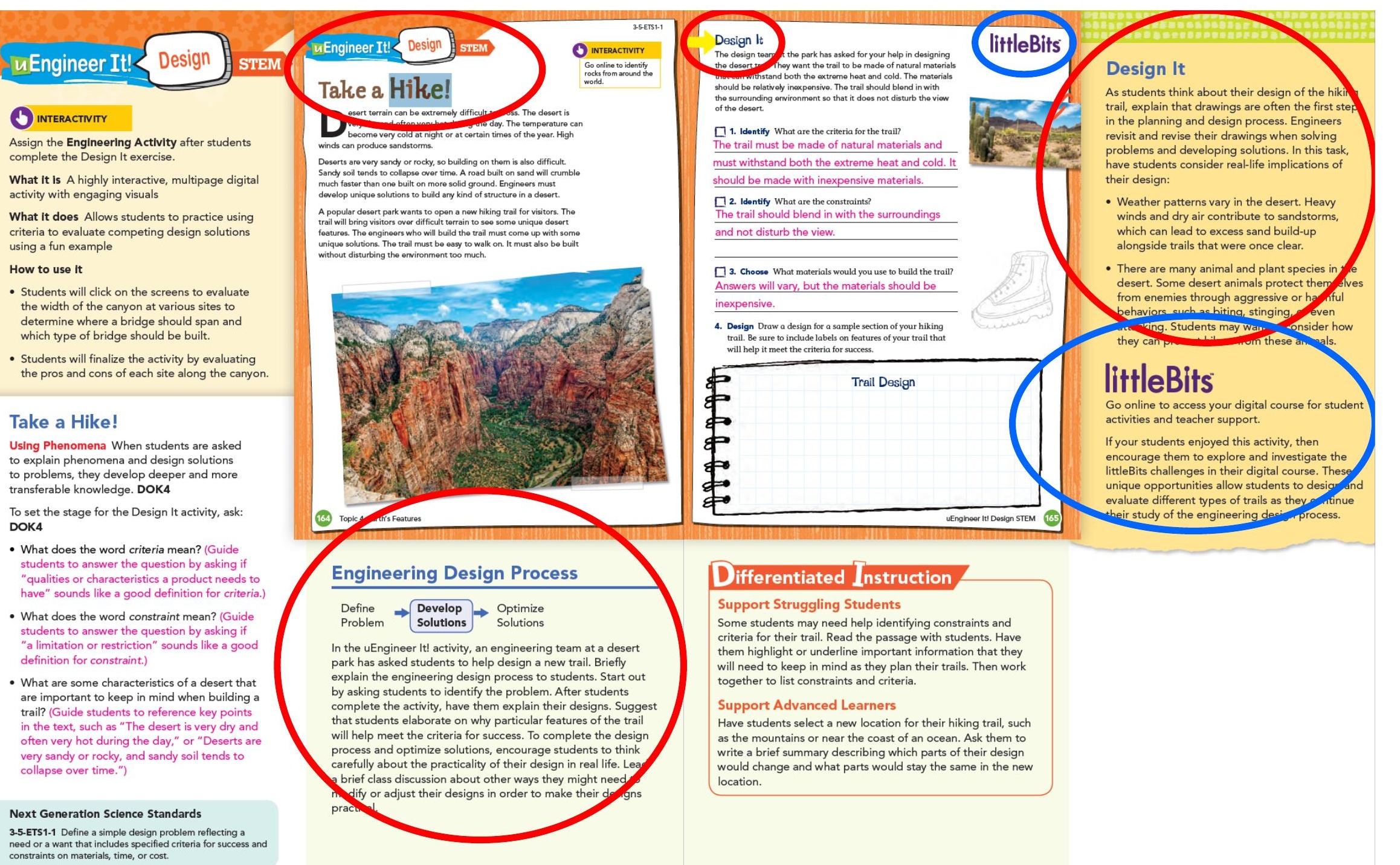

164 Topic 4 Earth's Features 


\section{Identifying Crosscutting Concepts:}

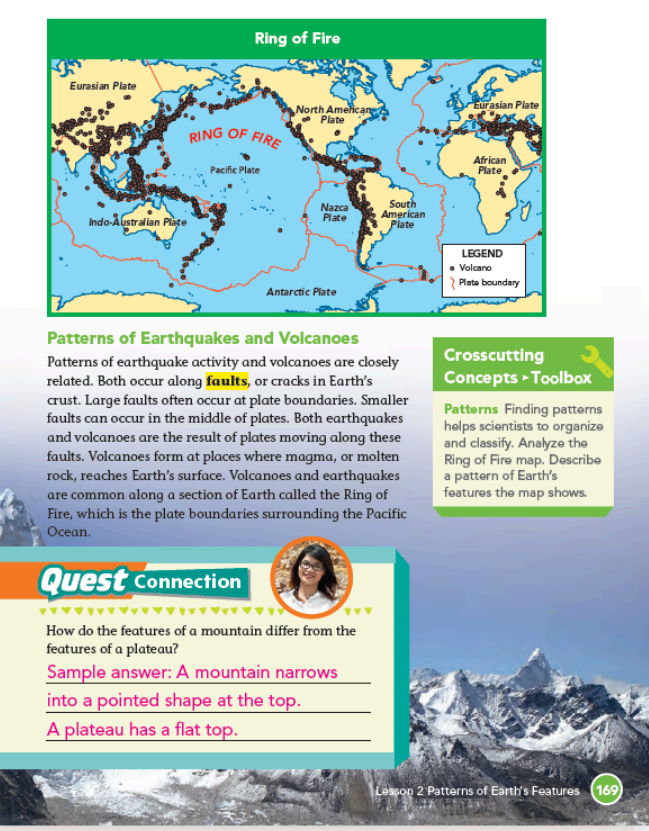

ELD Support

Reading Use the "Patterns of Earthquakes and Volcanoes" paragraph to help students practice their English vocabulary. Entering Have students find the context clues that define the word fault. Have students use these clues to explain what a fault is.

Beginning Have students identify text details that tell where large and small faults are located.

Developing Have students use text evidence to explain what the Ring of Fire is and where it is located.

Expanding Have students identify the main idea of the

Expeng

Bridging Have students explain how volcanoes and earthquakes occur, using evidence from the paragraph to

\section{SYNTHESIZE}

\section{Ointeactivitr}

Have students complete the Synthesize Activity. What it is Real-world scenario-based interactivities and engaging images

What it does Supports students in synthesizing and applying what they've learned throughout the lesson

How to use it

Students click through the screens to learn about mountain ranges form and discs predir ideas as a class.

- Then, students explore how tectonic plate movement and water can shape different

Finally, students categorize different landforms, plate movement or water. As a class, have students brainstorm other factors that could shape Earth's landforms.

\section{Connecting Concepts - Toolbox 3}

Patterns Explain why volcanoes are common in the Ring of Fire. Have students summarize the
plate boundary activity in the Ring of Fire. Tell plate boundary activity in the Ring of Fire. Tell
students to draw conclusions about the pattern
of volcanoes located around the Pacific Plate.

\section{Quest connection}

- Inform students that they will be sketching Check-ln.

- Have students name characteristics of mountains and plateaus. Remind them that they the Quest Check-In.

- Then have students use the characteristics of different.

Lesson 2 Patterns of Earth's Features 169 


\section{Identifying Crosscutting Concepts:}

"Crosscutting Concepts Toolbox"

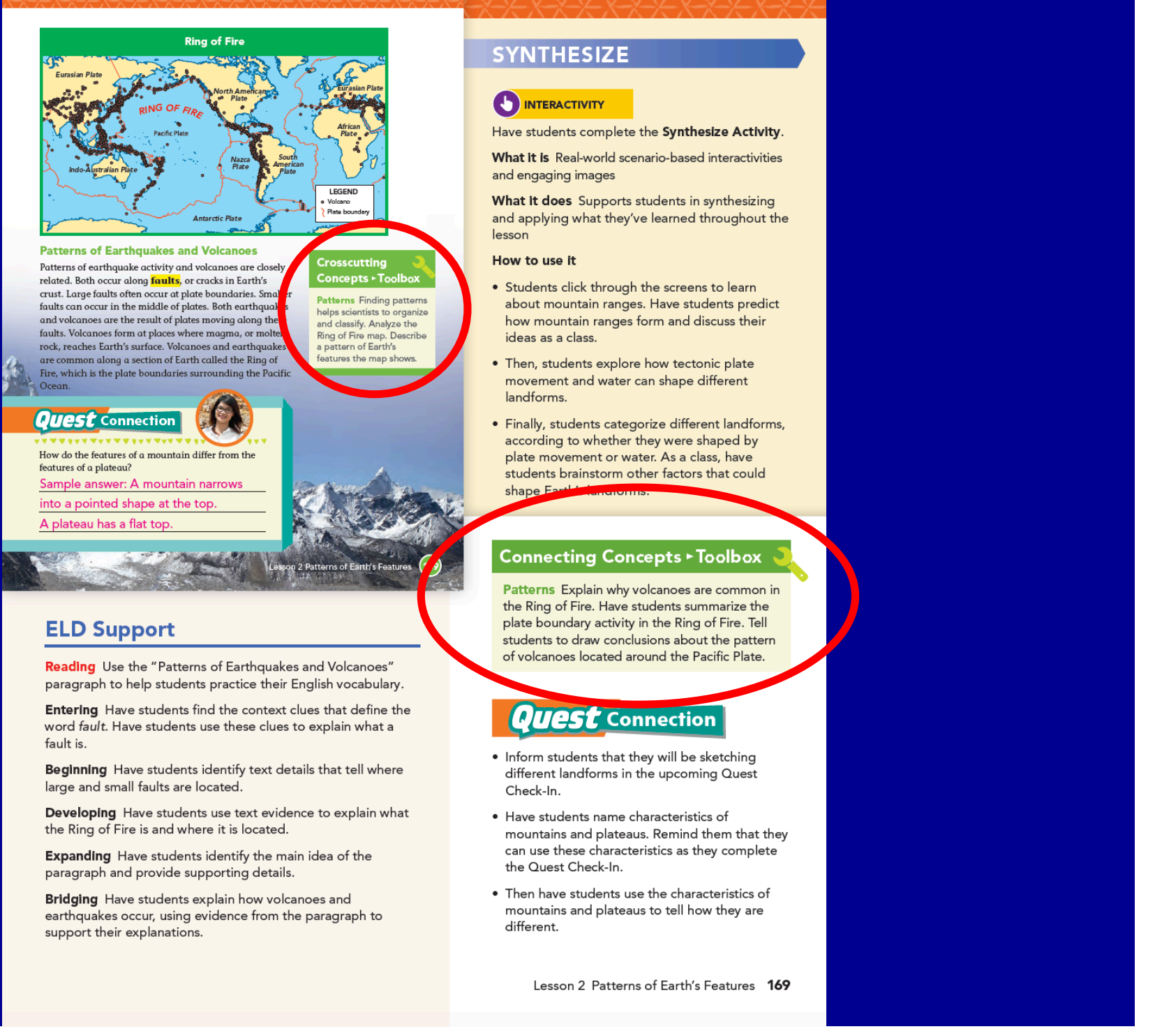




\section{Identifying Performance Expectations in Assessments:}

\section{$\varangle$ TOPIC 3}

Make Analogles Review the concept of action/ reaction forces. Explain that when an object exerts a
force on a second object, the second object always exerts a force back on the first object. Have students work in groups to think of an analogy for this
concept. One example is when people say " $\mathrm{Hi}$ " to

Focus on Mastery!

Draw Comparative Inferences Help students Draw Comparative Inferences Help students
analyz the action reaction forcest that DART
and the satelite exert on each other by asking

- sketch the events that led up to the collision.
-identify the action that led to the collision. - describe the force that is a result of the actio (n) draw a force arrow to represent this force an label it the action force.

site direction as the actial length and oppothis arrow the reaction force. Then describe the force that is represented by the reaction force.
(The satellite exerted a force on DART during the collision.)

区TOPIC 3 Review and Assess
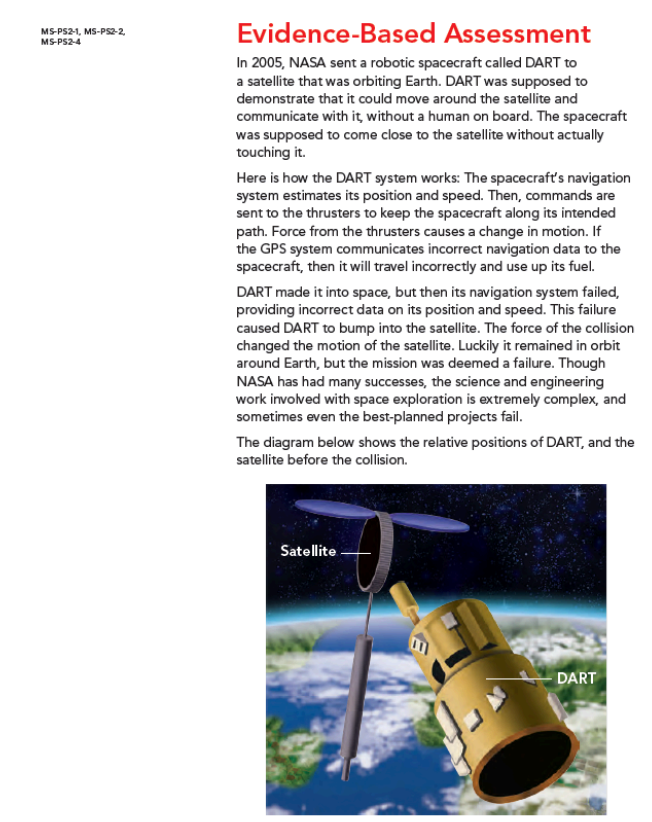

PROFESSIONAL DEVELOPMENT

Reflect

Which teaching strategies that you used throughout this topic best promoted
students' understanding?

NEXT GENERATION SCIENCE STANDARDS MS.P.P2:A Apply Newton's Third Law to design a solution to a
problem involving the motion of two colliding objects. MS.PS2.2 Plan an investigation to provide evidence that the
change in an object's motion dipends on the sum of the

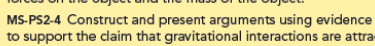
to support the claim that rravitational interactions are ath
tive and depend on the masses of $\mathrm{finteracting} \mathrm{objects.}$ 162 Forces and Motion

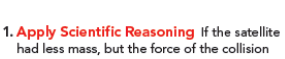

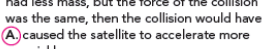

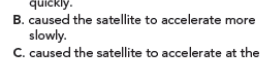

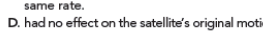

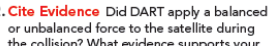

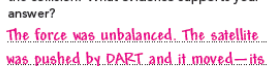

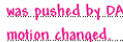

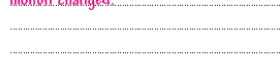

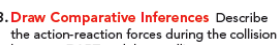
the action force wess the force of SART

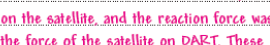
the force of the satellite on DART. These
forces are equal in strength but opposite.

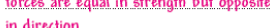

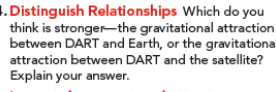

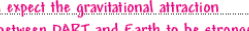
Earth is much morer massive than the

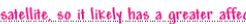
than the distance betwern DART and the

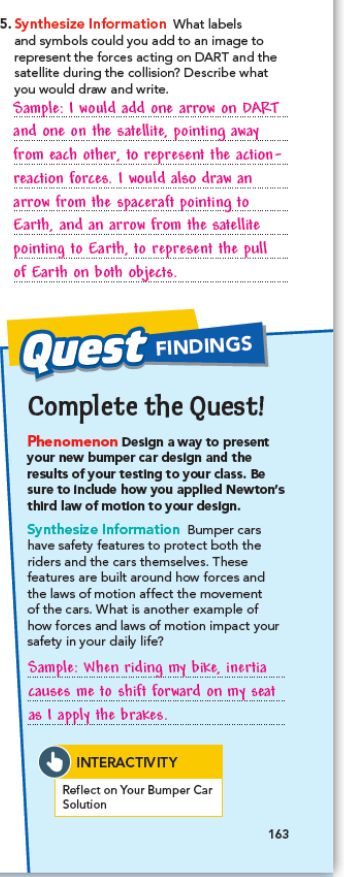

DIFFERENTIATED INSTRUCTION

L1 Support Struggling Students

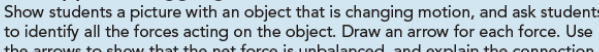
the arrows so show that the net torce is is unbalanced, and explain the connection

L3 Support Advanced Students

Have students explain why the
around Eath is unbalanced.
Scoring Notes

se the grading rubrics to assess students

Draw Comparative Inferences DOK 2, 5 points

$\begin{array}{ll}2 p t & \text { Student identifies the forces } \\ \text { of DART on the satellite as the }\end{array}$

action force.

$\begin{array}{ll}2 p t & \begin{array}{l}\text { Student identifies the force of the } \\ \text { satellite on DART as the reaction }\end{array}\end{array}$ satellit

1pt Student explains that the forces are equal in strength and oppo
site in direction

Distinguish Relationships DOK 2, 4 points

$\begin{array}{ll}2 p t & \begin{array}{l}\text { Student identifies the attraction } \\ \text { between DART and Earth as the }\end{array}\end{array}$ between DART and Earth as the
stronger force. Student refers to the relationship between mass, distance, and
gravity while explaining why that gravity while explaining why that
force is stronger.

Synthesize Information DOK 3, 4 points

$\begin{array}{ll}\text { 2pt } & \text { Student explains that arrows and } \\ \text { labels can be used to show the }\end{array}$ collision

$2 p$ Student explains that arrows and labels can be used to show exerts on both DART and the

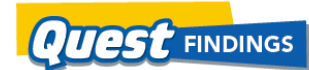

(b) interactivity

GO ONUNE to access....

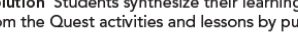
ting together their Findings and answering

students demononstrate their ability to engage
in argument from evidence. 


\section{Identifying Performance Expectations in Assessments:}

\section{$区$ TOPIC 3} force on a second object, the second dobject always dents work in groupsto dents work in groups to think of an analogy for this
concept. One example is when people say " $\mathrm{Hi}$ " to

Focus on Mastery!

Draw Comparative Inferences Help students

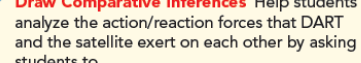

- sketch the events that led up to the collision.
-identify the action that led to the collision. - describe the force that is a result of the action on the satellite during the collision.) draw a force arrow to represent this force and label it the action force. draw a force arrow of equal length and oppo-
site direction as the action force arrow. Label
this arrow the reaction force. Then describe the this arrow the reaction force. Then describe the
force that is represented by the reaction force. (The satellite exe
the collision.)

$\varangle$ TOPIC 3 Review and Assess
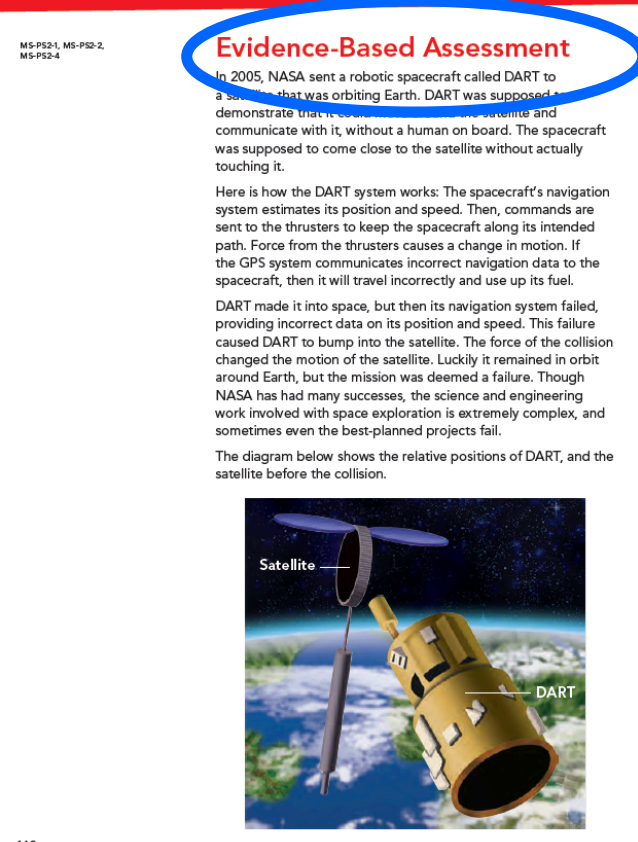

PROFESSIONAL DEVELOPMENT

Reflect

NEXT GENERATION SCIENCE STANDARDS Ms.PS2.1 Apply Newton's Third Law to design a solution to a
problem involving the motion of wo colliding objects.

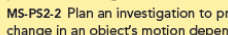
forces on the object and the mass of the object.
MS.PS2.4 Construct and present arcuments using evidescos MS.PS2.4 Construct and present arguments using evide
to support the cliim that gravitational interaction a are
tive and depend on

students' understanding?

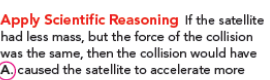 quickly.
B. cause the satellitilit to accelerate more
slowy.y slowly.
c. caused dhe satellite to accelerate at the
same rate. 2. Cite Evidence Did DART apply a balanced
or unblasanced force tothe satelitite during
the collision? What evidence supports your answer?
The force vas unbalanced. The satellite was.pusbed. by. DART and it moved - its otion changed}

3.Draw Comparative Inferencess Describe
the action-reaction forces during the collision on the satellite. and the reaction force was the force of the satellite on DART. These
forces are equal in strengith but opposite torces are equalin instrengith but oppositie Distinguish Relationships Which do you
think is stronger-the gravitational attraction

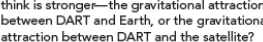
Strtaction between
Explatiny our answer: expect the gravitational attraction

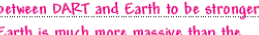
satellite, so it likely has a greater affed than the distance between DART and the than the
satellite.

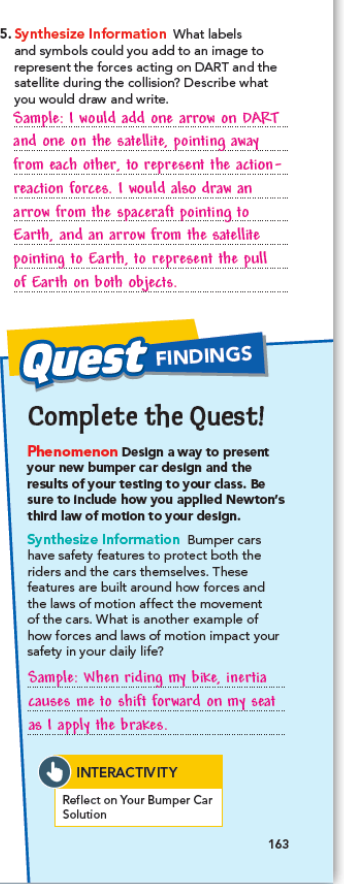

DIFFERENTIATED INSTRUCTION

L1 Support Struggling Students the arrows to show that the net force is unbalanced, and explain the connection

L3 Support Advanced Students

Have students explain why th
around Earth is unbalanced. the action force was the force of DART

Show students a picture with an object that is changing motion, and ask students
to identify all the forces acting on the object. Draw

Scoring Notes

Use the grading rubrics to assess students'

Draw Comparative Inferences DOK 2, 5 points

$\begin{array}{ll}2 p t & \begin{array}{l}\text { Student identifies the forces } \\ \text { of DART on the satellite as the }\end{array}\end{array}$

action force.

$\begin{array}{ll}2 p t & \text { Student identifies the force of the } \\ \text { satellite on DART as the reaction }\end{array}$ Student
satellite
force. Student explains that the forces are equal in strength and oppo-
site in direction

Distinguish Relationships DOK 2, 4 points

$\begin{array}{ll}2 p t & \begin{array}{l}\text { Student identifies the attraction } \\ \text { between DART and Earth as the }\end{array}\end{array}$ between DART and Earth as
stronger force. Student refers to the relationship between mass, distance, and
gravity while explaining why that gravity while explaining why that
force is stronger.

5. Synthesize Information DOK 3, 4 points

$\begin{array}{ll}\text { 2pt } & \begin{array}{l}\text { Student explains that arrows and } \\ \text { labels can be used to show the }\end{array}\end{array}$ collision

2pt Student explains that arrows and labels can be used to show exerts on both DART and the

\section{QRTEST FinoInos}

(b) interactivity

GO ONUNE to access...

Reflect on Your Bumper Car om the Quest activities and lessons by py ting together their Findings and answering students demonstrate their ability to engage 


\section{Any NGSS-designed Curricular Materials Should Incorporate the Five "NGSS Innovations"}

1. Three-Dimensional Learning

2. Buillding K-12 Progressions 


\section{Topic 4 Next Generation Learning Progressions}

\section{Earth"s Features}

Next Generation Science Standards 4-ESS2-1, 4-ESS2-2

Use these pages to identify the Science and Engineering Practices,

Disciplinary Core Ideas, and Cross
will be working toward in grade 4 .

\begin{tabular}{|c|c|}
\hline $\begin{array}{l}\text { Science and Engineering } \\
\text { Practices }\end{array}$ & $\begin{array}{l}\text { Grades K-2 } \\
\text { Students should already be } \\
\text { capable of... }\end{array}$ \\
\hline $\begin{array}{l}\text { SEP.3 Planning and Carrying } \\
\text { Out Investigations }\end{array}$ & $\begin{array}{l}\text { evaluating different ways of } \\
\text { observing and/or measuring a } \\
\text { phenomenon. }\end{array}$ \\
\hline $\begin{array}{l}\text { SEP.4 Analyzing and } \\
\text { Interpreting Data }\end{array}$ & $\begin{array}{l}\text { using observations to describe } \\
\text { patterns and/or relationships } \\
\text { in order to answer scientific } \\
\text { questions. }\end{array}$ \\
\hline Disciplinary Core Ideas & \\
\hline $\begin{array}{l}\text { ESS2.A Earth Materials and } \\
\text { Systems }\end{array}$ & $\begin{array}{l}\text { recognizing that wind and } \\
\text { water change the shape of } \\
\text { the land. }\end{array}$ \\
\hline $\begin{array}{l}\text { ESS2.B Plate tectonics } \\
\text { and large-scale system } \\
\text { interactions }\end{array}$ & $\begin{array}{l}\text { observing how maps show } \\
\text { where things are located. }\end{array}$ \\
\hline Crosscutting Concepts & \\
\hline CCC.1 Patterns & $\begin{array}{l}\text { recognizing that patterns can } \\
\text { be observed, used to describe } \\
\text { phenomena, and used as } \\
\text { evidence. }\end{array}$ \\
\hline CCC.2 Cause and Effect & $\begin{array}{l}\text { understanding that events } \\
\text { have causes that generate } \\
\text { observable patterns. }\end{array}$ \\
\hline
\end{tabular}

Grade 3-5

Students are working toward...

making observations or measurements

Pproduce data to explain a

comparing and contrasting data

collected by different groups in order

eir findings.

\section{understanding that rainfall helps to}

shape the land and affects the types of

living things found in a region.

recognizing that Earth's physical

earthquakes and volcanoes, and maps

can locate these features.

identifying similarities and differences in order to sort and classify natural objects and designed products.

\section{dentifying and testing causal}

elationships to explain chang evaluating the accuracy of various methods for collecting data.

analyzing and interpreting data to analyzing and interpreting data to
determine similarities and differences findings.

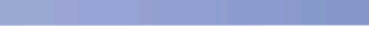

identifying that energy flows and matter cycles within and among Earth's systems.

identifying that plate tectonics is the unifying theory that explains movements of rocks at Exath's surface realizing that macroscopic patterns a
related to the nature of microscopic related to the nature of mice
and atomic-level structure.

classifying relationships as causal or correlational, and recognizing that correlation
causation.

\section{College \& Careers}

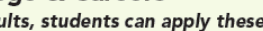
skills by

concting investigations to arities in anim behavior as a zookeeper.

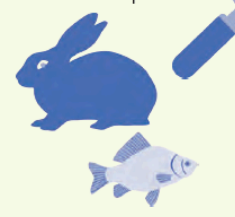

using Earth's physical features and yearly rainfall data to plant

$$
y
$$

serving and identifying -and-effect relationships care field.

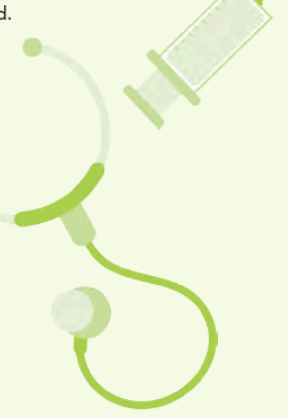




\section{Topic 4 Next Generation Learning Progressions}

\section{Earth"s Features}

Next Generation Science Standards 4-ESS2-1, 4-ESS2-2

Use these pages to identify the Science and Engineering Practices,

Disciplinary Core Ideas, and Cross
will be working toward in grade 4 .

\begin{tabular}{|l|}
\hline $\begin{array}{l}\text { Science and Engineering } \\
\text { Practices }\end{array}$ \\
\hline $\begin{array}{l}\text { SEP.3 Planning and Carrying } \\
\text { Out Investigations }\end{array}$ \\
\hline $\begin{array}{l}\text { SEP.4 Analyzing and } \\
\text { Interpreting Data }\end{array}$ \\
\hline
\end{tabular}

Grades K-2 Students should already be

capable of...

evaluating different ways of observing and/or measuring

using observations to describe in order to answer scientific questions.
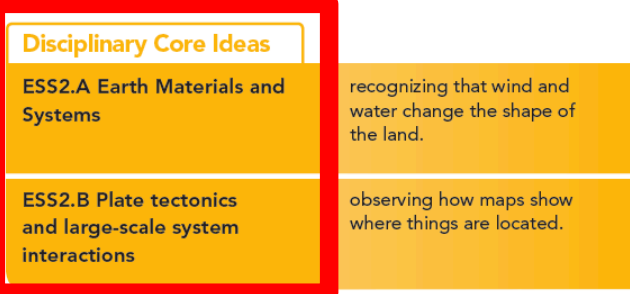

observing how maps show where things are located.

Crosscutting Concepts cCc.1 Patterns

Ccc.2 Cause and Effect

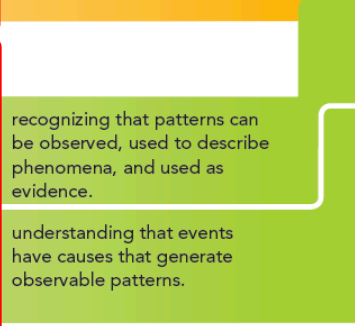

Grade 3-5

students are working toward...

making observations or measurements

to produce data to explain a

comparing and contrasting data

collected by different groups in order

eir findings.

understanding that rainfall helps to shape the land and affects the types of living things found in a region.

recognizing that Earth's physical

earthquakes and volcanoes, and maps

can locate these features.

identifying similarities and differences in
order to sort and classify natural objects

and designed products.

\section{identifying and testing causal
elationships and using these}

elationships to explain chang
College \& Careers

ents can apply these

Conducting investigations to

sty the similatives in anim

Students will develop the skills of.

evaluating the accuracy of various methods for collecting data.

analyzing and interpreting data to
determine similarities and differences

findings.

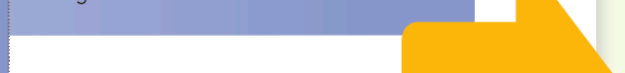

identifying that energy flows and

matter cycles within and among Earth's

identifying that plate tectonics is

the unifying theory that explains

and geological history.

realizing that macroscopic patterns a
related to the nature of microscopic

and atomic-level structure.

classifying relationships as causal or

correlational, and recognizing that

correlation
causation.

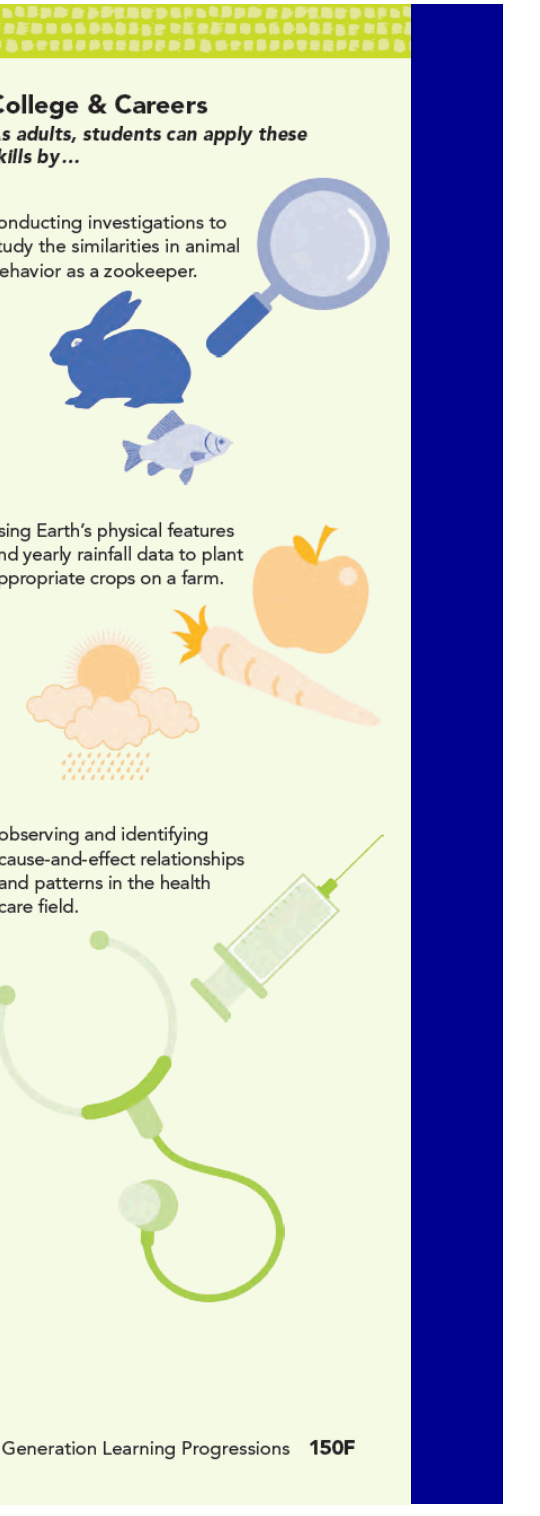




\section{Topic 4 Next Generation Learning Progressions}

\section{Earth"s Features}

Next Generation Science Standards 4-ESS2-1, 4-ESS2-2 will be working toward in grade 4.

\begin{tabular}{|l|}
\hline $\begin{array}{l}\text { Science and Engineering } \\
\text { Practices }\end{array}$ \\
\hline $\begin{array}{l}\text { SEP.3 Planning and Carrying } \\
\text { Out Investigations }\end{array}$ \\
\hline $\begin{array}{l}\text { SEP.4 Analyzing and } \\
\text { Interpreting Data }\end{array}$ \\
\hline
\end{tabular}

Grades K-2

Students should
capable of...

evaluating different ways of

observing and/or measuring a
phenomenon.

using observations to describe

patterns and/or relationships

in order to answer scientific questions.
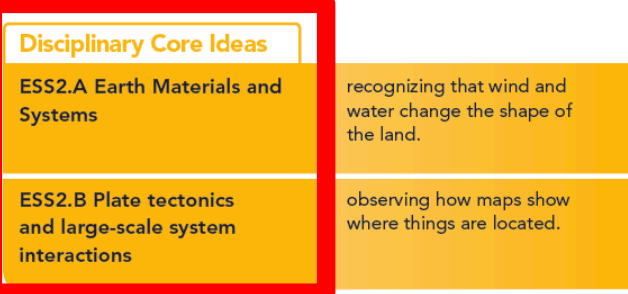

observing how maps show where things are located.
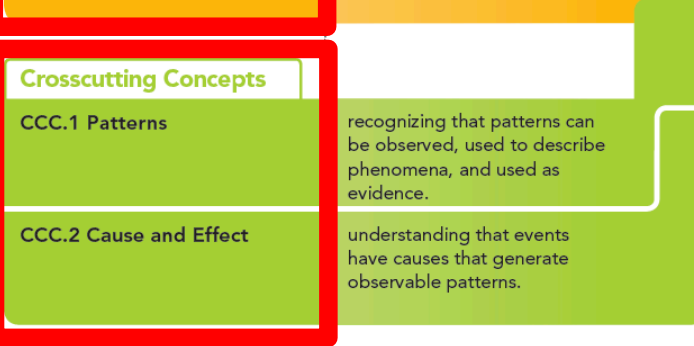

Grade 3-5

Students are workic

making observations or measurements

to produce data to explain

comparing and contrasting data

collected by different groups in order

their findings.

understanding that rainfall helps to shape the land and affects the types of

living things found in a region.

recognizing that Earth's physical

earthquakes and volcanoes, and maps

can locate these features. identifying similarities and differences in
order to sort and classify natural objects and designed products.

\section{Identifying and testing causal}

relationships to explain chang

College \& Careers

As aduts, students can apply these As alls by

(o dy the similarities in anima behavior as a zookeeper.

Students will develop the skills of

evaluating the accuracy of various methods for collecting data.

nalyzing and interpreting data to analyzing and interpreting data to
determine similarities and differences findings. matter cycles within and among Earth's

identifying that plate tectonics is the unifying theory that explains and geological history.

alizing that macroscopic patterns are related to the nature of microscopic

and atomic-level structure.

classifying relationships as causal or

correlational, and recognizing that

causation.

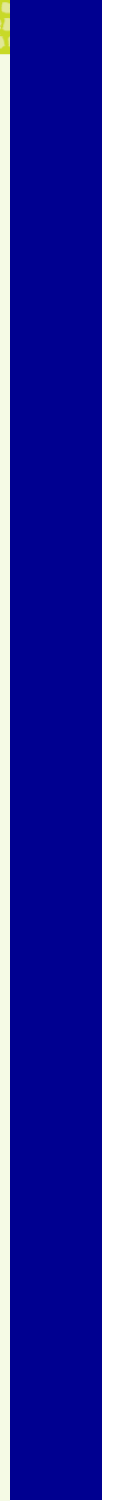




\section{Topic 4 Next Generation Learning Progressions}

\section{Earth"s Features}

Next Generation Science Standards 4-ESS2-1, 4-ESS2-2 Discill be working
wing toward in grade 4.

\begin{tabular}{|l|}
\hline $\begin{array}{l}\text { Science and Engineering } \\
\text { Practices }\end{array}$ \\
\hline $\begin{array}{l}\text { SEP.3 Planning and Carrying } \\
\text { Out Investigations }\end{array}$ \\
\hline $\begin{array}{l}\text { SEP.4 Analyzing and } \\
\text { Interpreting Data }\end{array}$ \\
\hline
\end{tabular}

\section{Grades K-2}

Students should
capable of...

evaluating different ways of

phenomenon.

using observations to describe

in order to answer scientific questions.

\begin{tabular}{|l|}
\hline Disciplinary Core Ideas \\
\hline $\begin{array}{l}\text { ESS2.A Earth Materials and } \\
\text { Systems }\end{array}$ \\
\hline $\begin{array}{l}\text { ESS2.B Plate tectonics } \\
\text { and large-scale system } \\
\text { interactions }\end{array}$ \\
\hline
\end{tabular}

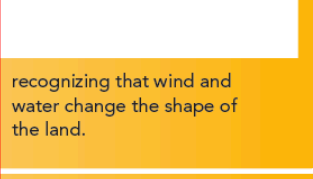

observing how maps show
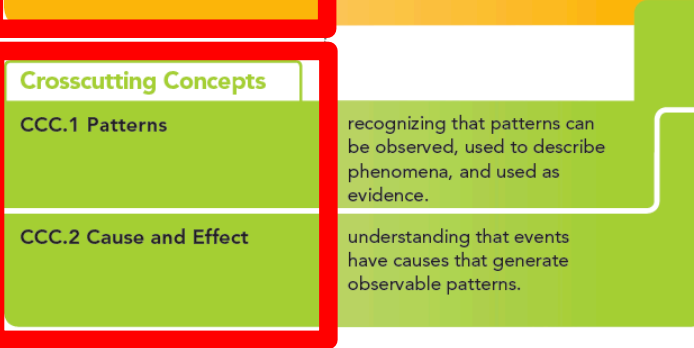

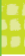

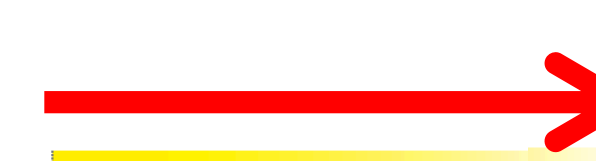

Students are working toward..

making observations or measurements to produce data to explain a phenomeno

comparing and contrasting data

collected by different groups in order

their findings.

understanding that rainfall helps to understanding that rainfall helps to
shape the land and affects the types of living things found in a region.

recognizing that Earth's physical

earthquakes and volcanoes, and maps

can locate these features. identifying similarities and differences in
order to sort and classify natural objects and designed products.

\section{dentifying and testing causal
elationships and using these}

relationships and using these
relationships to explain chang.
College \& Careers

As adults, students can apply these

conducting investigations to

behavior as a zookeeper.

Students will develop the skills of.

evaluating the accuracy of various methods for collecting data.

analyzing and interpreting data to
determine similarities and differences

findings.

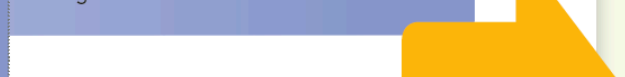

identifying that energy flows and

matter cycles within and among Earth's

identifying that plate tectonics is

the unifying theory that explains

movements of rocks at

realizing that macroscopic patterns a
related to the nature of microscopic

related to the nature of micel atomic-level structure.
and

classifying relationships as causal or

correlational, and recognizing that

correlation
causation.

(1)

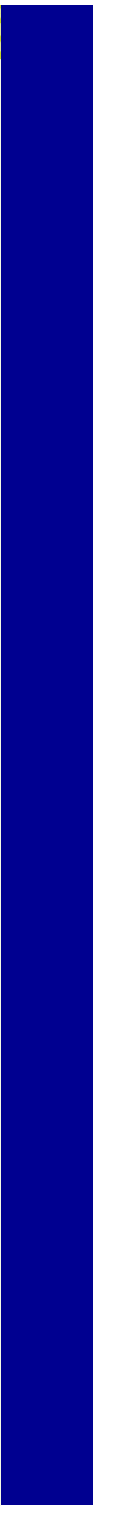




\section{Topic 4 Next Generation Learning Progressions}

\section{Earth"s Features}

Next Generation Science Standards 4-ESS2-1, 4-ESS2-2 Dilll be working toward in grade 4.
wilnary

\begin{tabular}{|l|}
\hline $\begin{array}{l}\text { Science and Engineering } \\
\text { Practices }\end{array}$ \\
\hline $\begin{array}{l}\text { SEP.3 Planning and Carrying } \\
\text { Out Investigations }\end{array}$ \\
\hline $\begin{array}{l}\text { SEP.4 Analyzing and } \\
\text { Interpreting Data }\end{array}$ \\
\hline
\end{tabular}

\section{Grades K-2}

Students should
capable of...

evaluating different ways of

observing and/or measuring a
phenomenon.

using observations to describe

patterns and/or relationship
in order to answer scientific

questions.
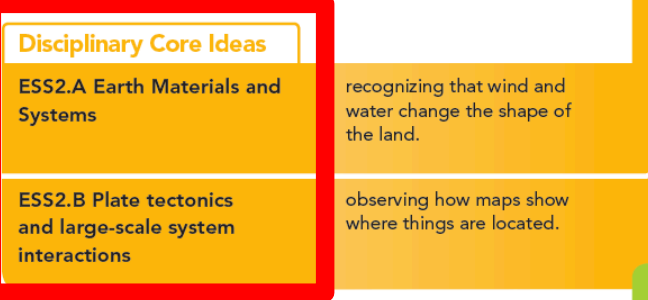

observing how maps show where things are located.

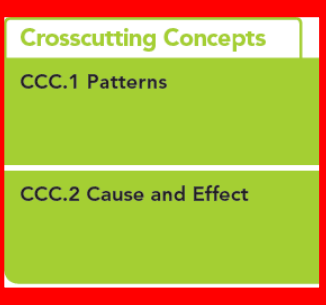

recognizing that patterns can
be observed, used to describe
phenomena, and used as
evidence.
understanding that events
have causes that generate
observable patterns.

Grade 3-5

ng toward...

making observations or measurements to produce data to explain a

comparing and contrasting data

collected by different groups in order

eir findings.

understanding that rainfall helps to understanding that rainfall helps to
shape the land and affects the types of living things found in a region.

recognizing that Earth's physical

can locate these features. identifying similarities and differences in
order to sort and classify natural objects and designed products.

\section{dentifying and testing causal
elationships and using these}

elationships to explain chang earthquakes and volcanoes, and maps

College \& Careers

can apply these

conducting investigations to

study the similarities in anim

behavior as a zookeeper.

evaluating the accuracy of various methods for collecting data.

analyzing and interpreting data to

analyzing and interpreting data to
determine similarities and differences in

findings.

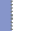

identifying that energy flows and

matter cycles within and among Earth's

identifying that plate tectonics is

the unifying theory that explains

movements of rocks at

realizing that macroscopic patterns are
related to the nature of microscopic

and atomic-level structure.

classifying relationships as causal or

correlational, and recognizing that

correlation
causation.

-

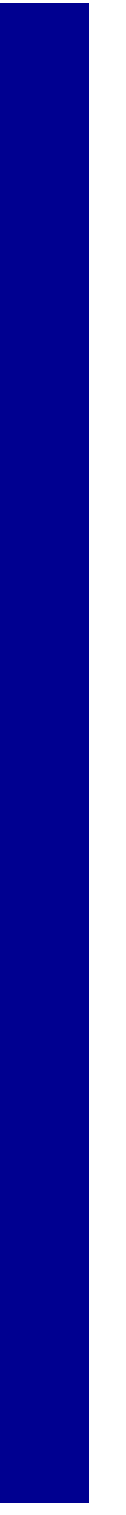




\section{Any NGSS-designed Curricular Materials Should Incorporate the Five "NGSS Innovations"}

1. Three-Dimensional Learning

2. Building K-12 Progressions

3. Alignment with Common Core English Language Arts and Mathematics 


\section{Identifying}

Common

Core Math Alignments:

\section{LESSON 4}

INVESTIGATE

Math Toolbox 6.RP.A.2

Analyze Relationships Guide students to
complete the table by reminding them to - review the meanings of mass and weight. - review the text to find the ratios of mass and weight for each planet and record them. - carry out the calle - check that an

rs are reasonable. Weight less mass than Earth and will be higher on a planet or moon that has more mass tha

Energy, Forces, and Motion Teach With Movement The following activity will does gravitational potential energy relate to kinetic energy?" Have students lift a notebook $3 \mathrm{~cm}$ and then $30 \mathrm{~cm}$. Ask students: Imagine dropping note surface. What is one difference you might notice when the books hit the surface? (Sample answer: The notebook dropped from the higher point will make a louder noise.) Imagine dropping notebools What is one difference you might notice when the books hit the sand? (Sample answer: The notebook dropped from the higher point will make a deeper

Academic Vocabulary Teach Strategies Help students better understan - What is the contert associate by aking. - What is the context of the text where the word - Associate used as a vert

one thing or person in connection with another thing or person "or "to be together with other word is used in the text?

- The word associate is used in different ways. It can be used as a verb, noun, or adjective. Write - Wentence using associate as a noun.
Write a sentence using associate as an adjective. 156 Forces and Motion
Math Toolbox

The Relationship Between Weight and Mass

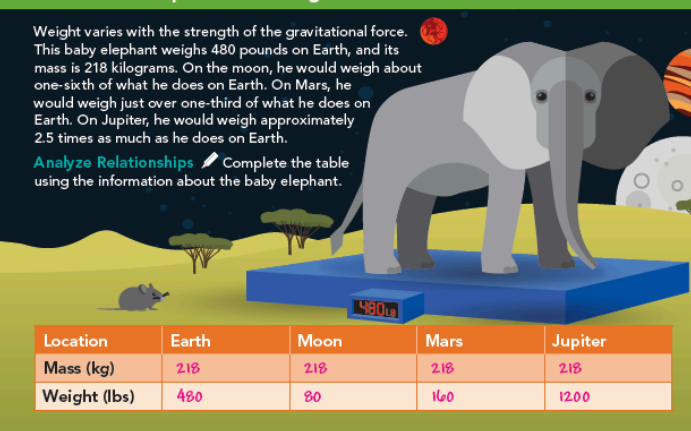

Energy, Forces, and Motion By now, you can see how forces such as gravity and friction
relate to motion. Recall that forces and motion are also related Gravitational Potential Energy As you know, the
potentlatenerery of an oblect is the energy stored in the object.
There are several different types of potentlal energy based on There are several different types of potential energy, based o
different types of forces. The type of potential energy that we

Academic Vocabulary means to connect something means to connect something
to somenthing glse in one's
mind. Write a sentence using associate as a noun.
Sample: I have an associate who helps me complete a project. an object's posittion. In general, the higher up an object is,
the greater its GPE. For example, as a diver climbs the ladder
lo a diving board, her GPE increases. The GPE of a skydiver increases as he rides the hellicopter to this jumping point. You
can calculatete the GPE of an obbect on Earth based on the mos of the object, the acceleration due to gravity $\left(9.8 \mathrm{~m} / \mathrm{s}^{2}\right)$, and the

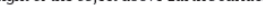

$\underset{\text { Gravitational potential }}{\text { energy (GPE) }}=$ Mass $\times \begin{aligned} & \text { Acceleration } \\ & \text { due to gravity }\end{aligned} \times$ Height

156 Foreses and Motion

PROFESSIONAL DEVELOPMENT

Reflect

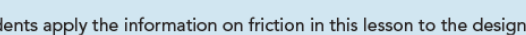
a better bumper car?

The lesson connected gravitational force to gravitational potential energy. What prior knowledge did you review to help students make the connection? What would you change the next time you taught this materia? 
Identifying

Common

Core Math

Alignments:

"Math

Toolbox"

\section{LESSON 4}

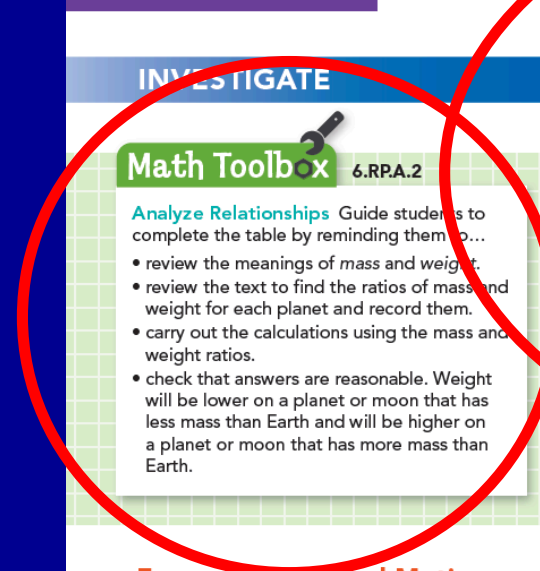

Energy, Forces, and Motion

Teach With Movement The following activity will does gravitational potential energy relate to kinetic energy?" Have students lift a notebook $3 \mathrm{~cm}$ and then $30 \mathrm{~cm}$. Ask students: Imagine dropping notesurface. What is one difference you might notice when the books hit the surface? (Sample answer: The notebook dropped from the higher point will
make a louder noise. Imagine dropping notebooks make a louder noise.) Imagine dropping noteboots What is one difference you might notice when the books hit the sand? (Sample answer: The notebook
dropped from the higher point will make a deeper dropped from the higher
impression in the sand.)

Academic Vocabulary Teach Strategies Help students better understan the meaning of the word associate by asking... - What is the context of the text where the word - Associate used as a vert

one thing or person in connection with another thing or person" or "to be together with other word is used in the text?

ciate is used in different ways. It can be used as a verb, noun, or adjective. Write - Write a sentence using associate as an adjective. 156 Forces and Motion
Math Toolbox

The Relationship Between Weight and Mass Weight varies with the strength of the gravitational force.
This babs elephant weighs 480 pounds on Earth, and its

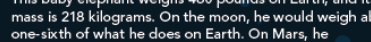

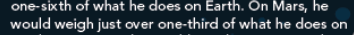

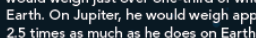

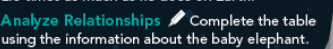
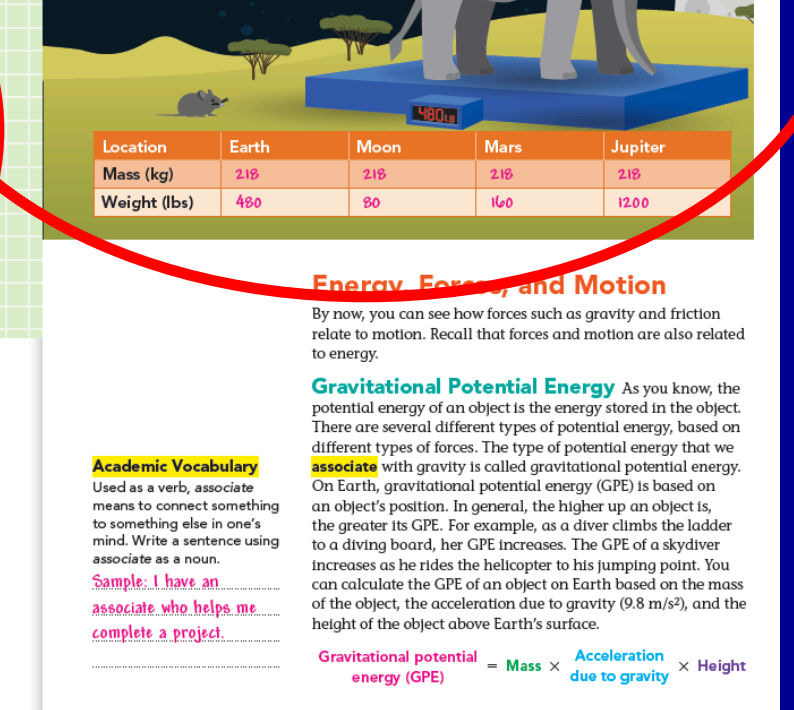

156 Foreses and Motion

PROFESSIONAL DEVELOPMENT

Reflect

How might students apply the information on friction in this lesson to the design of a better bumper car? The lesson connected gravitational force to gravitational potential energy. What
prior knowledge did you review to help students make the connection? What would you change the 


\section{Identifying}

\section{Common}

\section{Core}

\section{English} Alignments:

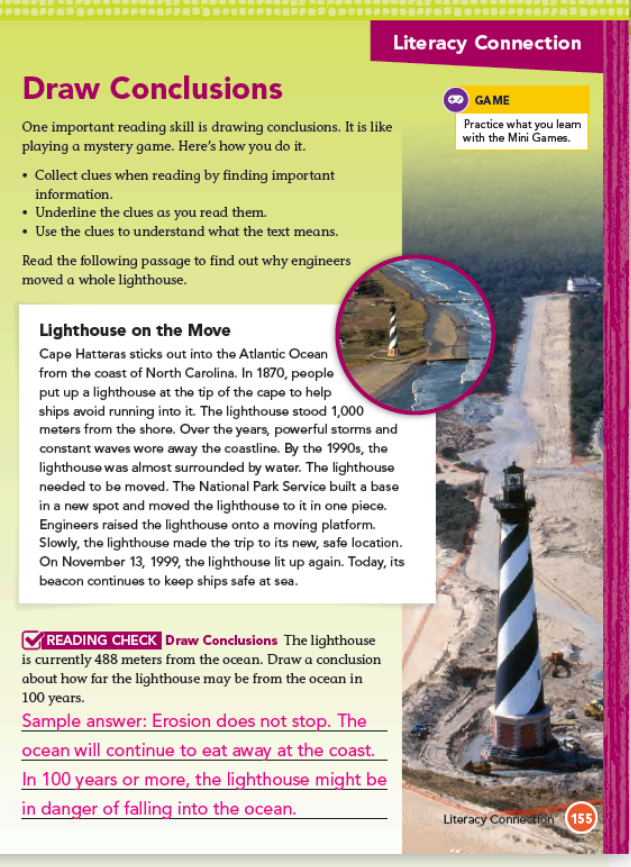

Differentiated Instruction

Use the following Leveled Readers and STEM Engineering Reader to provide additional science content, introduce science phenomena, and differentiate your students' reading
options.

BELOW LEVEL Learn About Earth's Features

ON LEVEL Earth's Features

ADVANCED All About Earth's Features

STEM ENGINEERING Earth's Features

\section{Literacy Connection}

\section{(6) game}

Have students play the Min! Games to practice

\section{(1)}

Have students explore the Leveled Readers and STEM Engineering Reader to learn more about

\section{Draw Conclusions}

Explain that more can be learned from a text than what is explicitly written. Often, it is necessary to look at text clues that can lead to a deeper understanding, especially when combined with
the reader's prior knowledge. Focus students' the reader's prior knowledge. Focus students'
attention on finding clues that help them draw conclusions in order to answer the Reading Check question. With a partner, have students share which parts of the reading they underlined. This
activity uses the ELA Speaking and Listening skill activity uses the ELA Speaking and Listening skill
of participating in collaborative conversations.

\section{READING CHECK}

Draw Concluslons Ask students to share their answers to the question, using evidence from the the subject matter. 
Identifying Common

\section{Core}

English

Alignments:

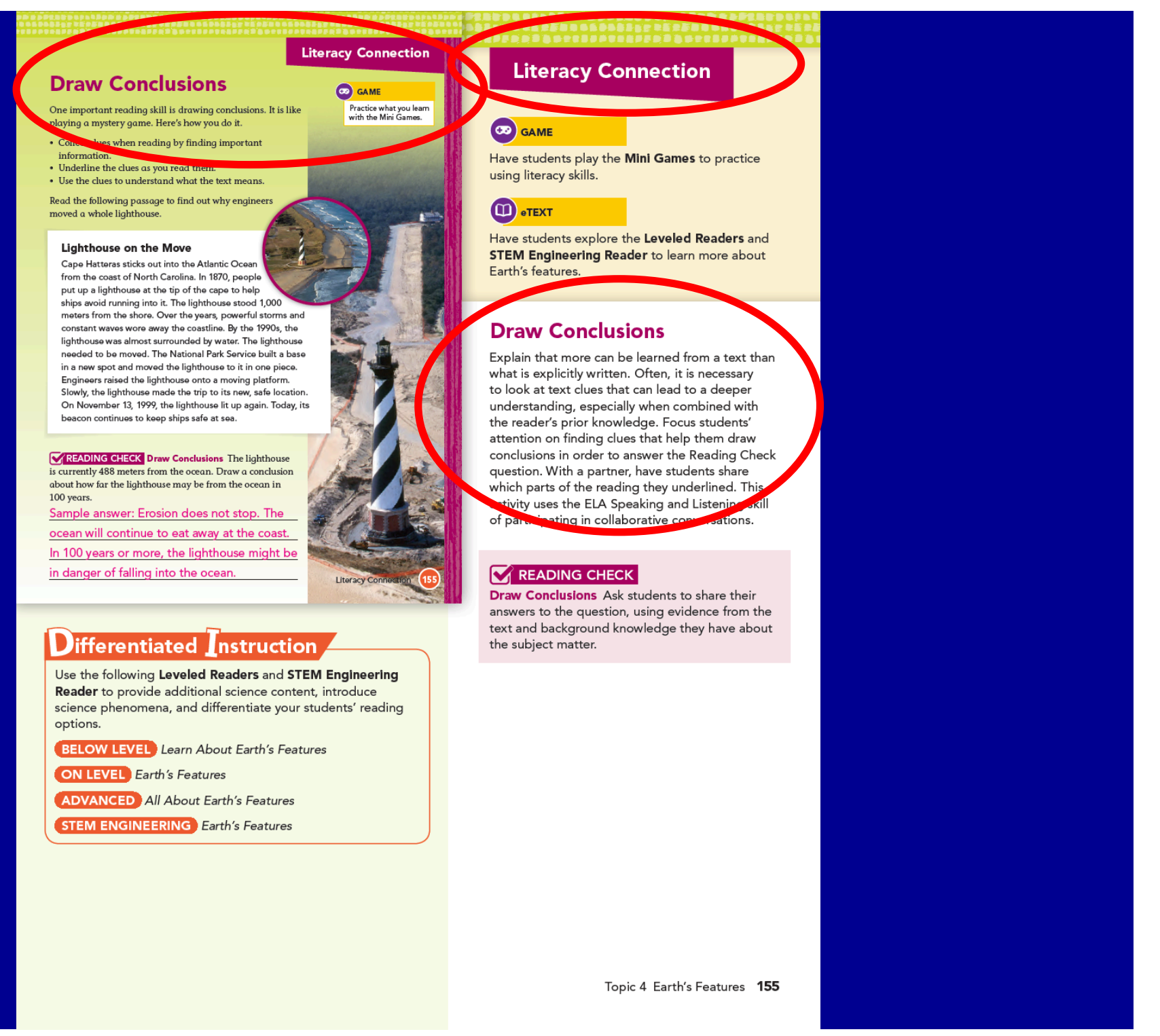




\section{Identifying}

Common

\section{Core}

English Alignments:

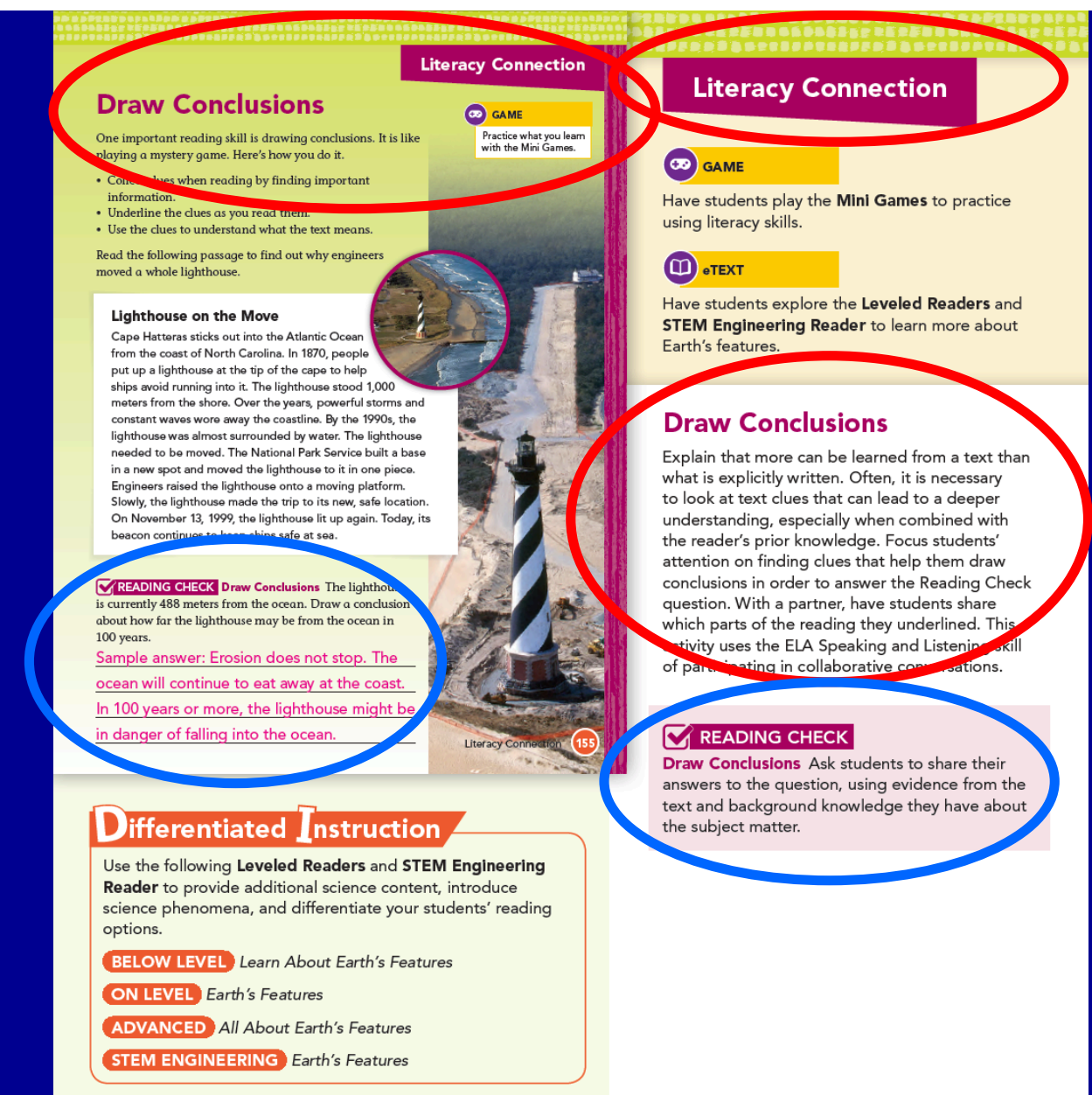




\section{Any NGSS-designed Curricular Materials Should Incorporate the Five "NGSS Innovations"}

1. Three-Dimensional Learning

2. Building K-12 Progressions

3. Alignment with Common Core English Language Arts and Mathematics

4. Making Sense of Phenomena and Designing Solutions to Problems 


\section{Topic 4}

Earth"s Features

Storyline

Using Phenomena Students will come to the Classroom having seen different landforms in their everyday lives. As your students progress through experiences to help them better understand how Earth's features change over time. Students will use observable events that occur in and around Earth's features, such as the events they see in photos and investigations in this topic. They will use their science knowledge to explain or predict
these observable events. In this topic, students will learn to identify landforms, rocks, and minerals. They will provide and change over time. They will examine and make maps to show important land features. They will also explore rocks, minerals, and soil. Students will learn about chemical and physical weathering, and explore how weathering relates to erosion.

Students will be introduced to science and engineering practices SEP. 3 and SEP. 4 by planning and carrying out investigations to study how rain affects land, and analyzing and interpreting data
to observe how Earth's plates form land features.

Key science vocabulary will be introduced thoughout the topic. Some vocabulary in this topic include legend, canyon, butte, fault, igneous, erosion.

Students will also practice the important literacy skil and Crosscuting Concept of identitying to practice this skill through the Reading Checks and Literacy Connection. Finally, students will practice the math standard MP.5 by using tools to test how a rock can wear away.

Next Generation Sclence Standards

4ESS2-1 Make observations and/or measurements to provide evidence of the effects of weathering or the rate of
erosion by water, ice, wind, or vegetation. 4ESS2-2 Analyze and interpret data from maps to describe
patterms of Earth's features. 3.5-ETS1-1 Define a simple design problem reflecting a need or a want that includes specified
constraints on materials, time, or cost

150 Topic 4 Earth's Features
Topic 4

\section{Farth's Features}

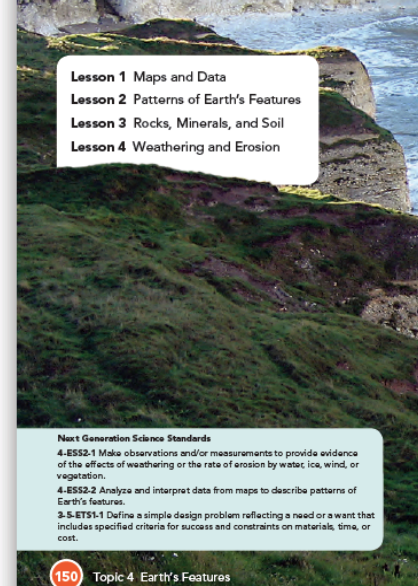

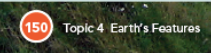

.

Topic Materials List

Consumable - Bottom half of a gallon milk . jug (15)

- Plastic cup (45)

- Sand (2 large bags)

- Paper plate (30)

- Craft stick (30)

- Foam and plastic cup (30)

-White glue (15)

- Sandstone sample (1 large

bag)

- Limest

bag)

- Chalk (15 pieces)

- Cardboard (15 shee

Go oninne to access
your digital course.

(i) .TEXT

(I) Interactivity

(i) Virtual LaB (8) ASSESSMEN

\section{ton 4}
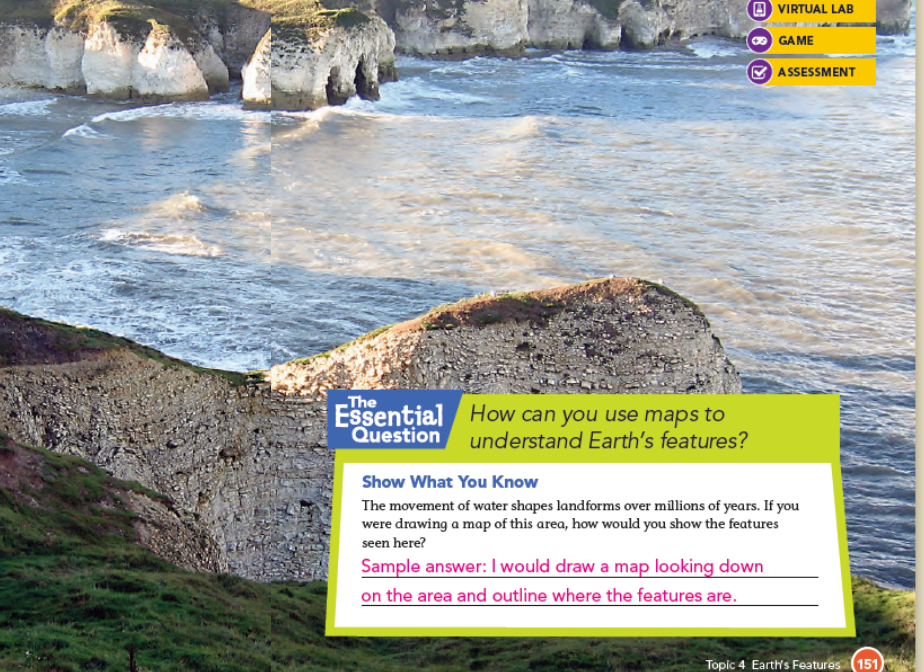

Toplc 4 Earths Feature, (15):
Differentiated Instruction

Support Struggling Students

photo. Ask students how they might show the difference

between the water and land on a map. Have them trace the
shoreline with their finger, and explain how the shoreline could be shown on a map.

Support Advanced Learners

Encourage students to think about the impact of external

influences on the landforms, such as building homes or

businesses in an area. Have them create a map that includes

that these structures may have on the landscape.
Have students name the different features they see in the

\section{(D) VIDEo}

Watch a Professional Development Video to

\section{(1) .TEXT}

The Student eTEXT lets students experience all of the topic pages in a digital context.

\section{(b) interactivity}

The Synthesize Activity is a great way for students to practice applying what they've learned.

\section{(b) INTERACTIVTTY}

The Engineering Activity is a great way for your students to think, plan, and design like engineers.

\section{(6) VIRTUAL LAB}

The Virtual Lab allows students to use different maps to choose the best location to place a

\section{(9) game}

The Mini Games provide a fun way for students practice what they have learned in the lesson.

\section{( ASSESSMENT}

The Topic Test is carefully built to check for deep understanding of key concepts. Remediation is prescribed automatically to provide what studen

\section{EShe
Essential As students conduct
Question
investigations in each lesson, they will practic}

- Magnet (15)

- Rock samples (1 large bas)

- Safety goggles (30)

- Plastic spray bottle (15)

*Materials listed per class demonstrating the topic and lesson standards. At the end of the topic, students will be able to understand Earth's features?

Show What You Know Ask students to look carefully at the photo and are most important to show on a map. describe features in the landscape that they 


\section{Topic 4}

Earth"s Features

Storyline

Using Phenomena Students will come to the Classroom having seen different landforms in their everyday lives. As your students progress through experiences to help them better understand how Earth's features change over time. Students will use observable events that occur in and around Earth's features, such as the events they see in photos and investigations in this topic. They will use the rcience knowledge to

In this topic, students will learn to identify landforms, rocks, and minerals. They will provide and change over time. They will exame maps to show important land features. They will also explore rocks, minerals, and soil. Students will learn about chemical and physical weathering, and explore how weathering relates to erosion.

Students will be introduced to science and engineering practices SEP. 3 and SEP. 4 by planning and carrying out investigations to study how rain affects land, and analyzing and interpreting data
to observe how Earth's plates form land features.

Key science vocabulary will be introduced thoughout the topic. Some vocabulary in this topic include legend, canyon, butte, fault, igneous, erosion.

Students will also practice the important literacy skill and Crosscuting Concept of identitying to practice this skill through the Reading Checks and Literacy Connection. Finally, students will practice the math standard MP.5 by using tools to test how a rock can wear away.

Next Generation Sclence Standards

4ESS2-1 Make observations and/or measurements to provide evidence of the effects of weathering or the rate of
erosion by water, ice, wind, or vegetation. 4ESS2-2 Analyze and interpret data from maps to describe
patterns of Earth's features. 3.5-ETS1-1 Define a simple design problem reflecting a need or a want that includes specified
constraints on materials, time, or cost

150 Topic 4 Earth's Features
Topic 4

\section{Farth's Features}

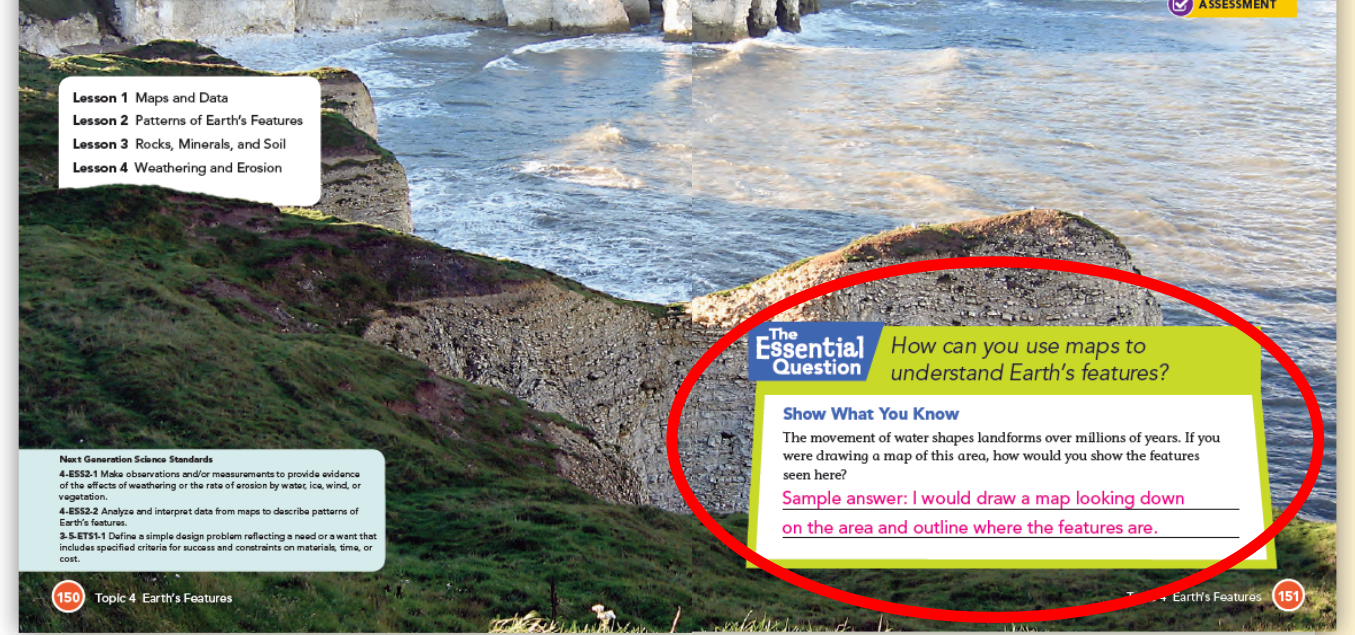

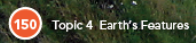

Topic Materials List

Consumable
- Bottom half of a gallon milk

. jug (15)

- Pand (2 large bags)

- Soil (1 large bag)

- Paper plate (30)

- Craft stick (30)

- Foam and plastic cup (30)

- White glue (15)

- Sandstone sample (1 large

bag)

Limest

- Chalk (15 pieces)

- Cardboard (15 sheet

Nonconsumable - Rectangular sponges (30)

bag

- Hand lens (15)

- Magnet (15

- Nail (15)

- Recky samples (1 large bag)

- Clear jar with lid (15

Plastic spray bottle (15)

- Streak plate (15)

*Materials listed per class

\section{Differentiated Instruction}

Support Struggling Students

Have students name the different features they see in the photo. Ask students how they might show the difference between the water and land on a map. Have them trace the be shown on a map.

Support Advanced Learners

Encourage students to think about the impact of external influences on the landforms, such as building homes or businesses in an area. Have the create a map that includes that these structures may have on the landscape.

\section{(Dideo}

Watch a Professional Development Video to

\section{(1)}

The Student eTEXT lets students experience all the topic pages in a digital context.

\section{(b) interactivity}

The Synthesize Activity is a great way for students to practice applying what they've learned.

\section{(b) interactivitr}

The Engineering Activity is a great way for your students to think, plan, and design like engineers.

\section{(4) VIRTUAL LAB}

The Virtual Lab allows students to use different maps to choose the best location to place a

\section{(9) game}

The Mini Games provide a fun way for students practice what they have learned in the lesson.

\section{(1) ASSESSMENT}

The Topic Test is carefully built to check for deep
understanding of key concepts. Remediation is

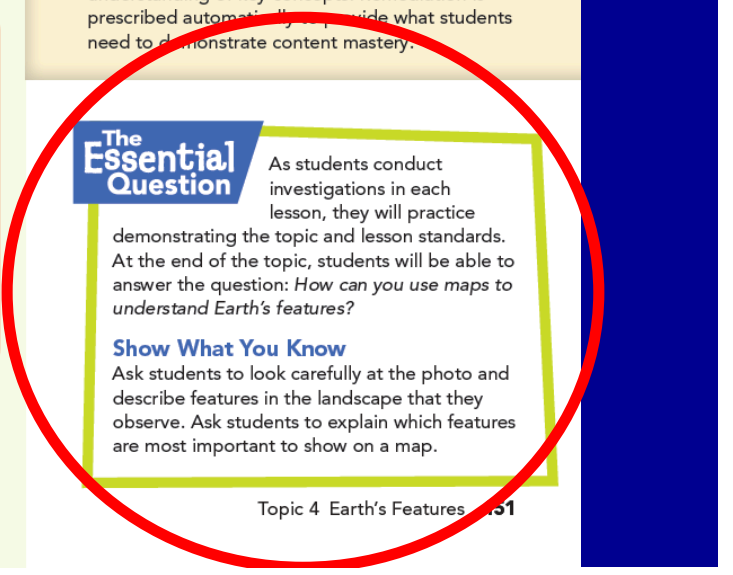




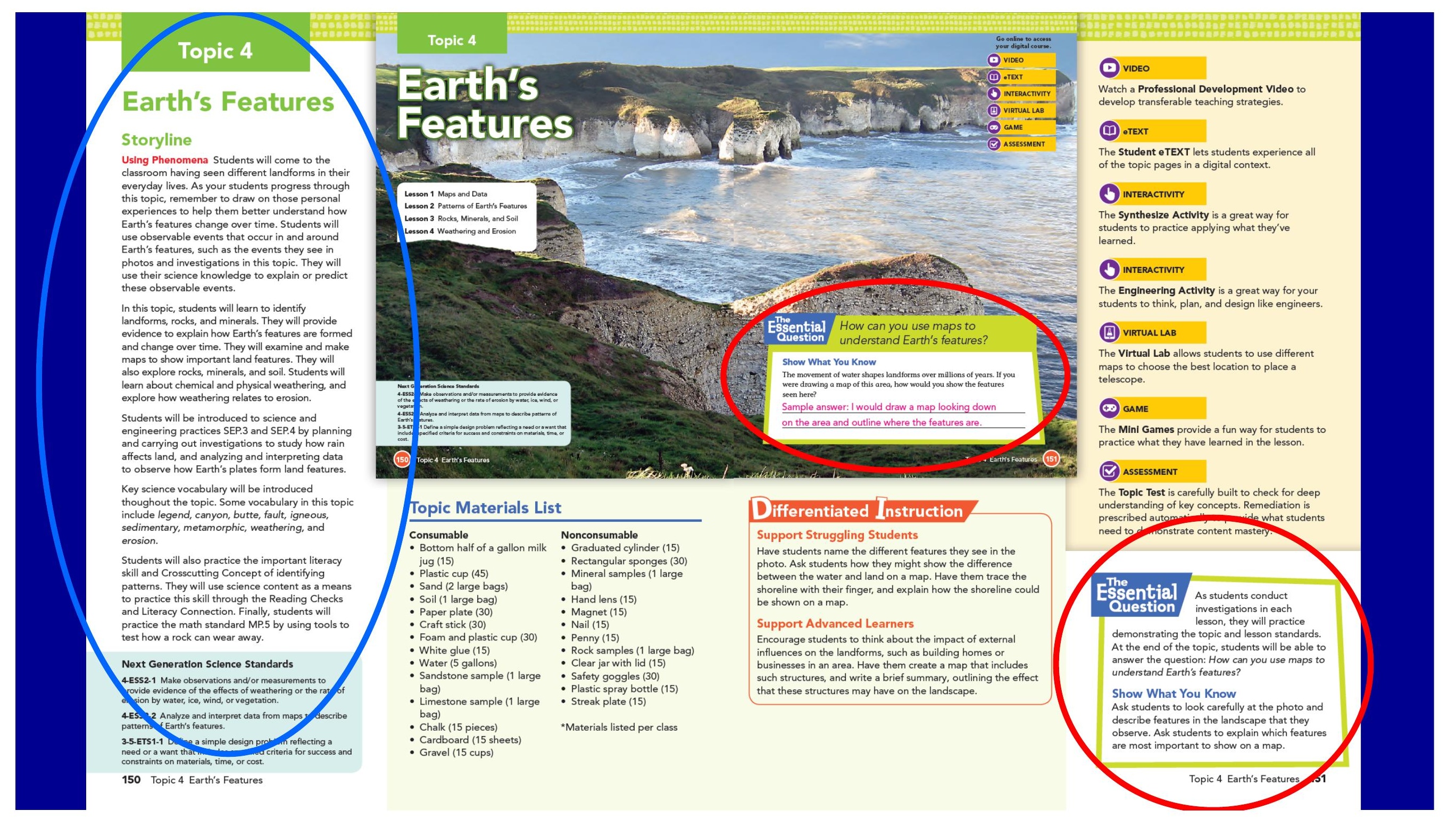




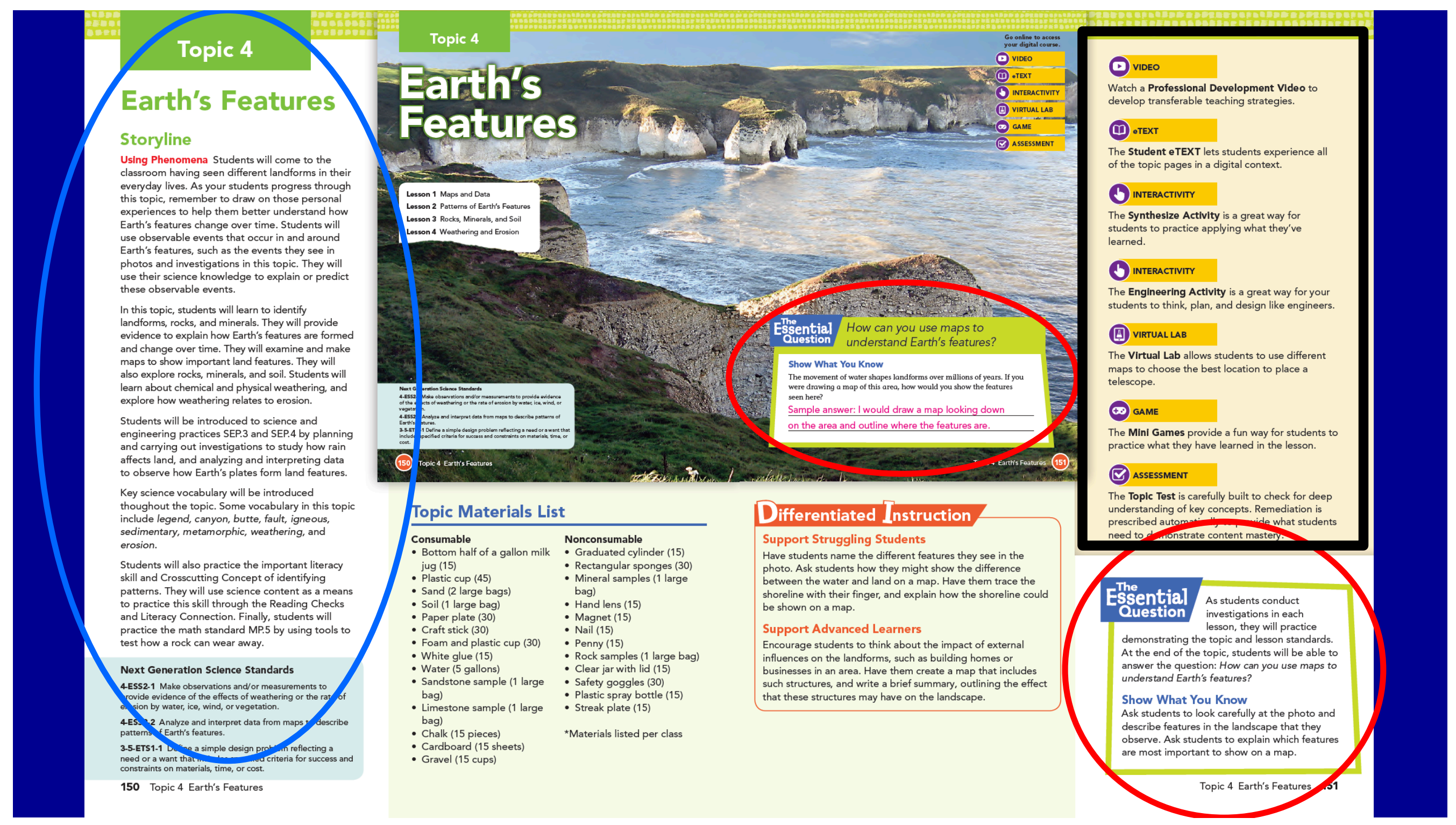




\section{QUeSt Kickoff}

Does X Mark the Spot? That's Up to You!

Using Phenomena Students are introduced to the topic Quest by reading a letter from Salen problem-based learning project students work on throughout the Quest The art on the path shows different landforms that were formed through Earth's processes. Have students explain how a geologist may use these land features to figure out how land changes over millions of years.

\section{Focus on Mastery}

Analyzing and Interpreting Data Throughout Ane Quest, students will use models to gather evidence that will help them explain how Earth's
features form and change over time. Discuss the ways that geologists may collect data and analyze it to better understand Earth's features and how they have been formed and changed over time. Then have students list examples of evidence th can be found throughout the Ouest. Examples include:

- Other scientists' studies

- observation and study of landform examples - Models of landforms

- Maps from different time periods

Have students share their examples and keep

Next Generation Sclence Standards 4ESS2-1 Make observations and/or measurements to
provide evidence of the effects of weathering or the rate of provide evivence of the eifects of weat
erosion by water, ice, wind, or vegetation. 4ESS2-2 Analyze and interpret data from maps to describe

152 Topic 4 Earth's Features

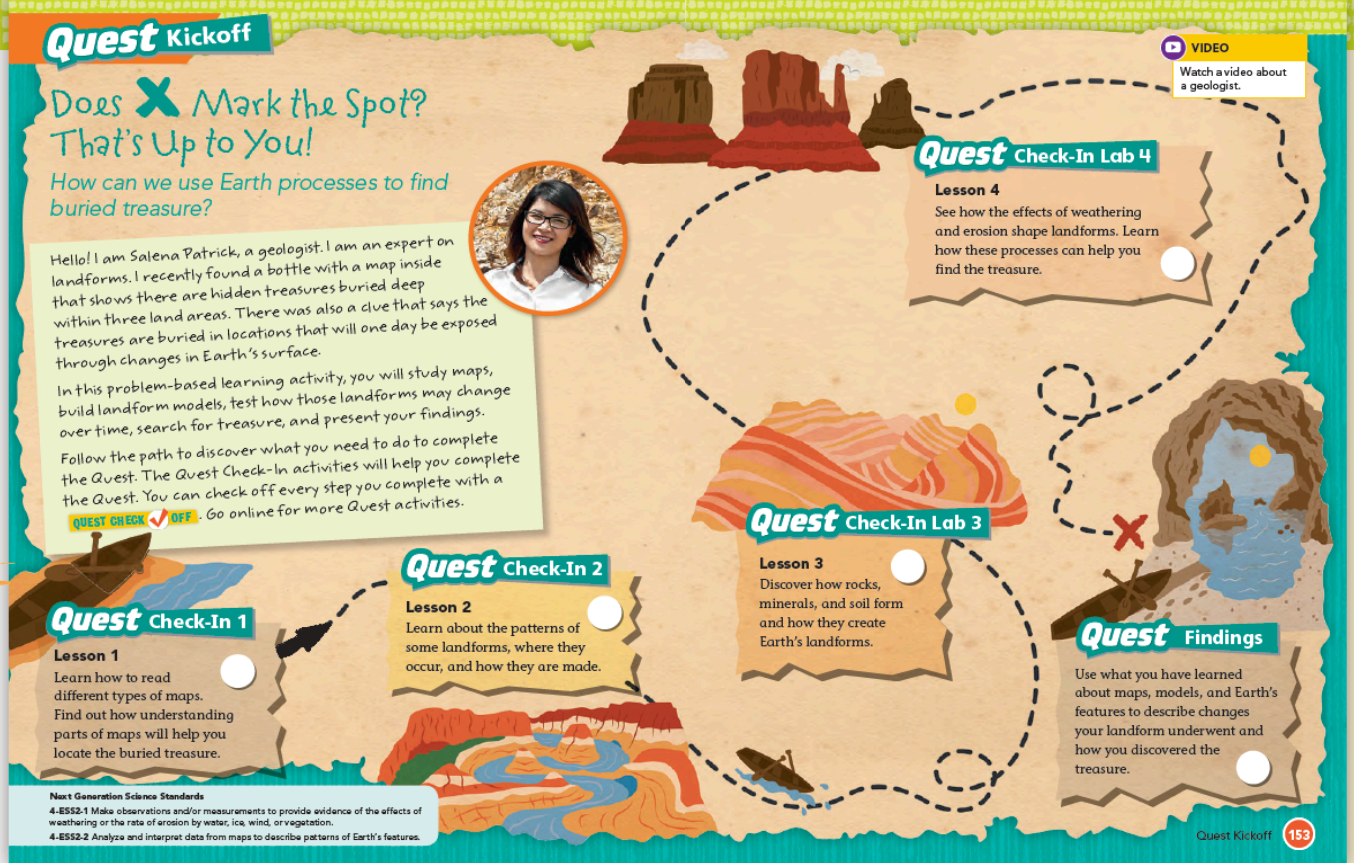

\begin{abstract}
Quest Path
Using Phenomena Quests are problem-based learning projects for students to work on throughout a topic. They help bring the topic content alive for students. By taking on a real-world problem and solving it, students come to understand why it is Quests also provide the opportunity for students to demonstrate mastery of Performance Expectations (PEs), engage in Science and Engineering Practices (SEPs), and interact with Crosscutting Concepts (CCCs) and Disciplinary Core Ideas (DCls).

Encourage students to track their progress by checking off the white circles for each step of the Quest.

- In the Check-In for Lesson 1, students will implement 4-ESS2-2 when they learn how to create a legend, a common map represented on a map as they begin their search for treasure.

- In the Check-In for Lesson 2, students are introduced to the patterns of different landforms. They will practice 4-ESS2-2
\end{abstract}

while looking closely at the characteristics of the landforms including how they are made.

- In the Check-In Lab for Lesson 3, students apply their compose Earth's landforms, practicing 4-ESS2-1 and SEP.3.

-In the Check-In Lab for Lesson 4, students explore how the processes of weathering and erosion form new landforms. treasure as they practice 4-ESS2-1 and SEP.3.

presentation that shows how weathering and erosion impact Earth's landforms. They practice 4-ESS2-1, 4-ESS2-2, and
- In the Findings, students will plan and produce a

\section{(1) VIDEO}

Have

What it is Video, short answer prompts, and

What is does Connects the topic career, a

geologist, to the Quest project and provides the purpose of the Quest.

How to use it

Have students watch the video to explore the career of a geologist.

- Students will practice following instructions to read a map to determine the location of

buried treasure on the map.

Then have students complete the screens in
which they ask questions about the Quest.

\section{(1) DOCUMENT}

Have students use the Quest Checklist as a Quest management tool. This tool will help them keep

(1).) DOCUMENT

The Quest Rubric is a self-assessment tool to help students evaluate their own performance as they complete the Quest project. The rubric also students' performance-based project

\section{(3) INTERACTIVITY}

The Quest Findings digital activity provides students with the opportunity to discover how
landforms are formed and change over time. 


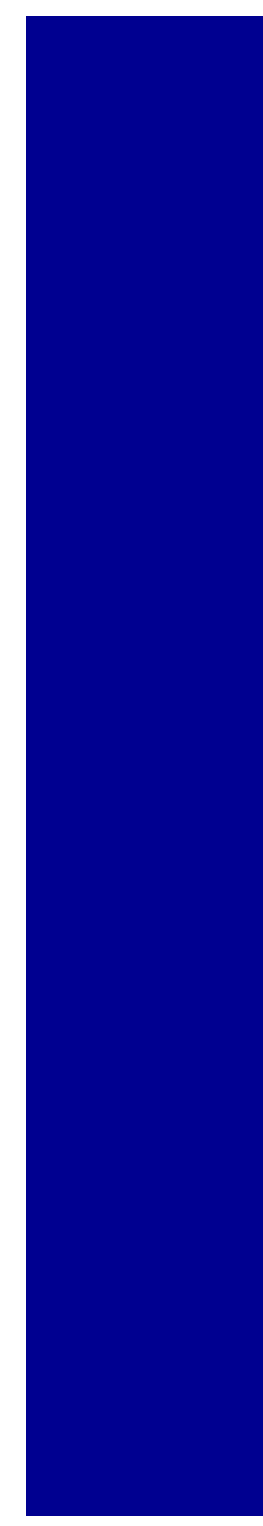

\section{AUPSE Kickoff \\ Does X Mark the Spot? Thats Upto You!}

Using Phenomena Students are introduced to the topic Quest by reading a letter from Salen Patrick, a geologist. The letter explains the work on throughout the Ouest. The art on the path shows different landforms that were formed through Earth's processes. Have students explain how a geologist may use these land features to fgure out how land changes over millions of years.

\section{Focus on Mastery}

Analyzing and Interpreting Data Throughout A evidence that will help them explain how Earth's
features form and change over time. Discuss the ways that geologists may collect data and analyze it to better understand Earth's features and how they have been formed and changed over time. Then will students list examples of evidence the an be found throughout the Ouest. Examples include:

Other scientists's studies

- Observation and study of landform examples - Models of landforms

- Maps from different time periods

Have students share their examples and keep

Next Generation Sclence Standards 4ESS2-1 Make observations and/or measurements to
provide evidence of the effects of weathering or the rate of erosion by water, ice, wind, or vegetation. 4ESS2-2 Analyze and interpret data from maps to describe

152 Topic 4 Earth's Features

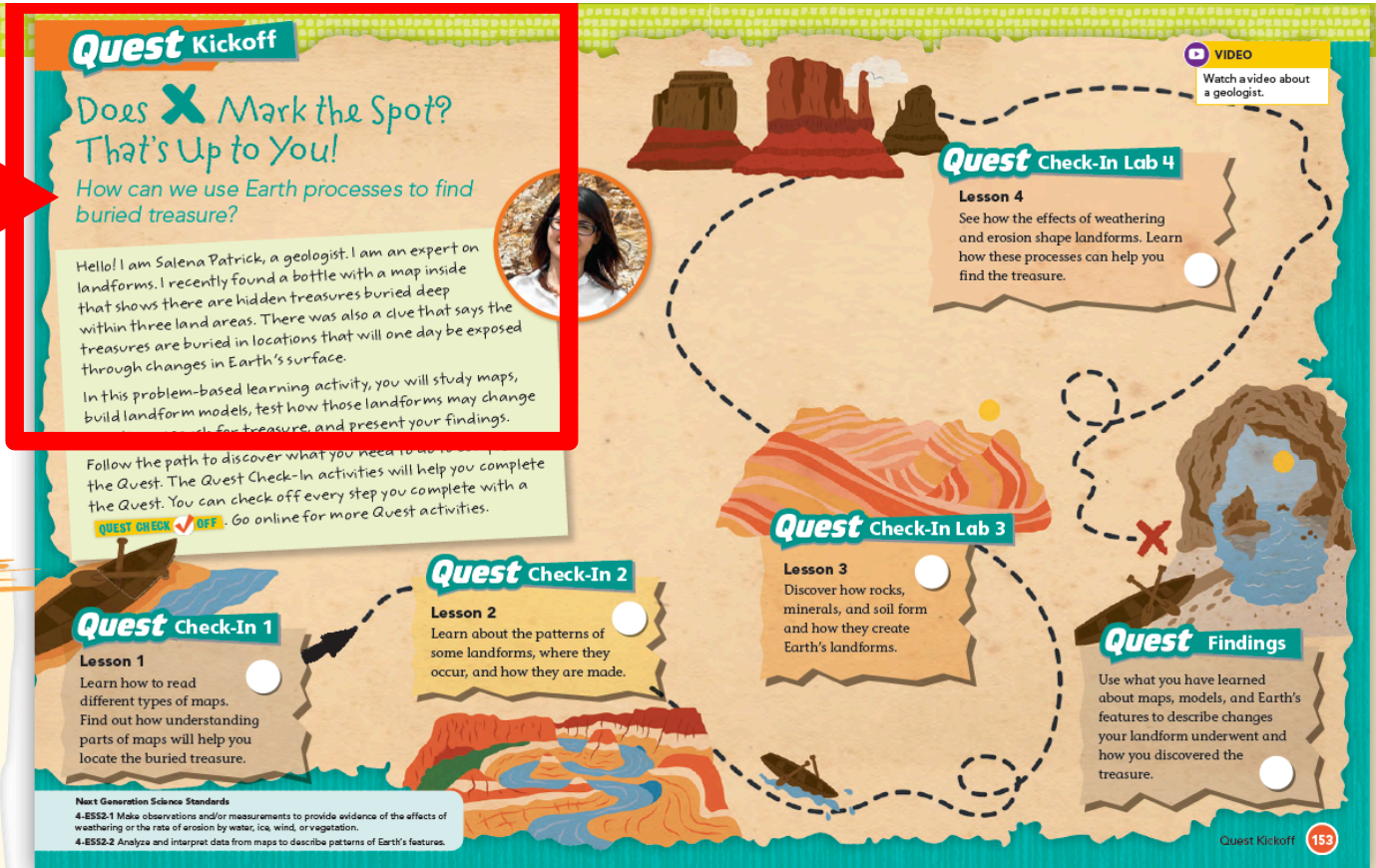

\begin{abstract}
Quest Path
Using Phenomena Quests are problem-based learning projects for students to work on throughout a topic. They help bring the topic content alive for students. By taking on a real-world problem and soling it, students come tounderstand why it is Quests also provide the opportunity for students to demonstrat mastery of Performance Expectations (PEs), engage in Science and Engineering Practices (SEPs), and interact with Crosscutting Concepts (CCCs) and Disciplinary Core Ideas (DCls).

Encourage students to track their progress by checking off the white circles for each step of the Quest.

- In the Check-In for Lesson 1, students will implement 4-ESS2-2 when they learn how to create a legend, a common map
tool. This will help them think about how land features represented on a map as they begin their search for treasure.

- In the Check-In for Lesson 2, students are introduced to the patterns of different landforms. They will practice 4-ESS2-2
\end{abstract} Understanding these processes will help students find the treasure as they practice 4-ESS2-1 and SEP.3.

- In the Findings, students will plan and produce a

presentation that shows how weathering and erosion impact Earth's landforms. They practice 4-ESS2-1, 4-ESS2-2, an

\section{(1) viDe}

Have

What It is Video, short answer prompts, and

What is does Connects the topic career, a geologist, to the Quest project and provides the purpose of the Quest.

How to use it

Have students watch the video to explore the career of a geologist.

- Students will practice following instructions to read a map to determine the location of

buried treasure on the map.

Then have students complete the screens in
which they ask questions about the Quest.

\section{(1) DOCUMENT}

Have students use the Quest Checklist as a Quest management tool. This tool will help them keep
track of the Quest tasks they have completed.

\section{(-).) DOCUMENT}

The Quest Rubric is a self-assessment tool to help students evaluate their own performance as they complete the Quest project. The rubric also students' performance-based project

\section{(3) interactivity}

The Quest Findings digital activity provides students with the opportunity to discover how
landforms are formed and change over time.

- In the Check-In Lab for Lesson 3, students apply their understanding of rocks, minerals, and soil to discover how the compose Earth's landforms, practicing 4-ESS2-1 and SEP.3. - In the Check-In Lab for Lesson 4, students explore how the 


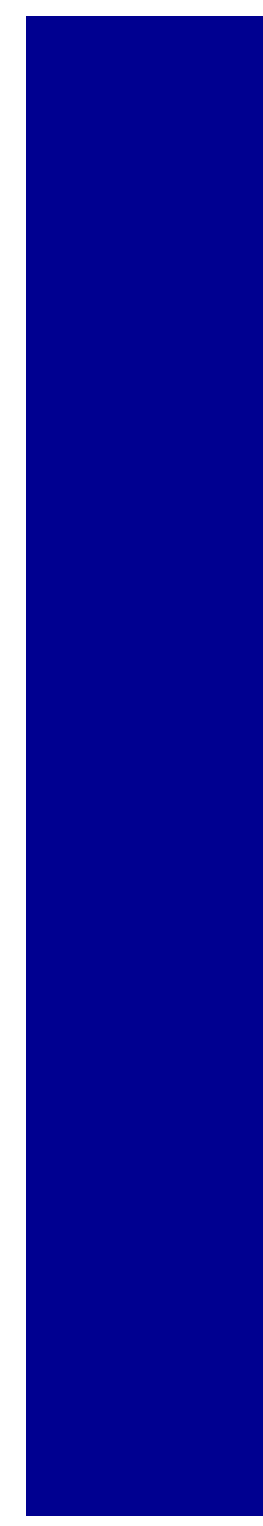

\section{AUPSE Kickoff \\ Does X Mark the Spot? Thats Upto You!}

Using Phenomena Students are introduced to the topic Quest by reading a letter from Salen Patrick, a geologist. The letter explains the work on throughout the Ouest. The art on the path shows different landforms that were formed through Earth's processes. Have students explain how a geologist may use these land features to fgure out how land changes over millions of years.

\section{Focus on Mastery}

Analyzing and Interpreting Data Throughout

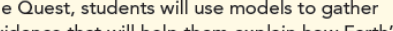
features form and change over time. Discuss the ways that geologists may collect data and analyze it to better understand Earth's features and how they have been formed and changed over time. Then will students list examples of evidence th an be found throughout the Ouest. Examples include:

Other scientists's studies

- Observation and study of landform examples - Models of landforms

- Maps from different time periods

Have students share their examples and keep

\section{Next Generation Sclence Standards}

4ESS2.1 Make observations and/or measurements to
provide evidence of the effects of weathering or the rate of

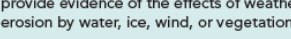

4ESS2-2 Analyze and interpret data from maps to describe

152 Topic 4 Earth's Features

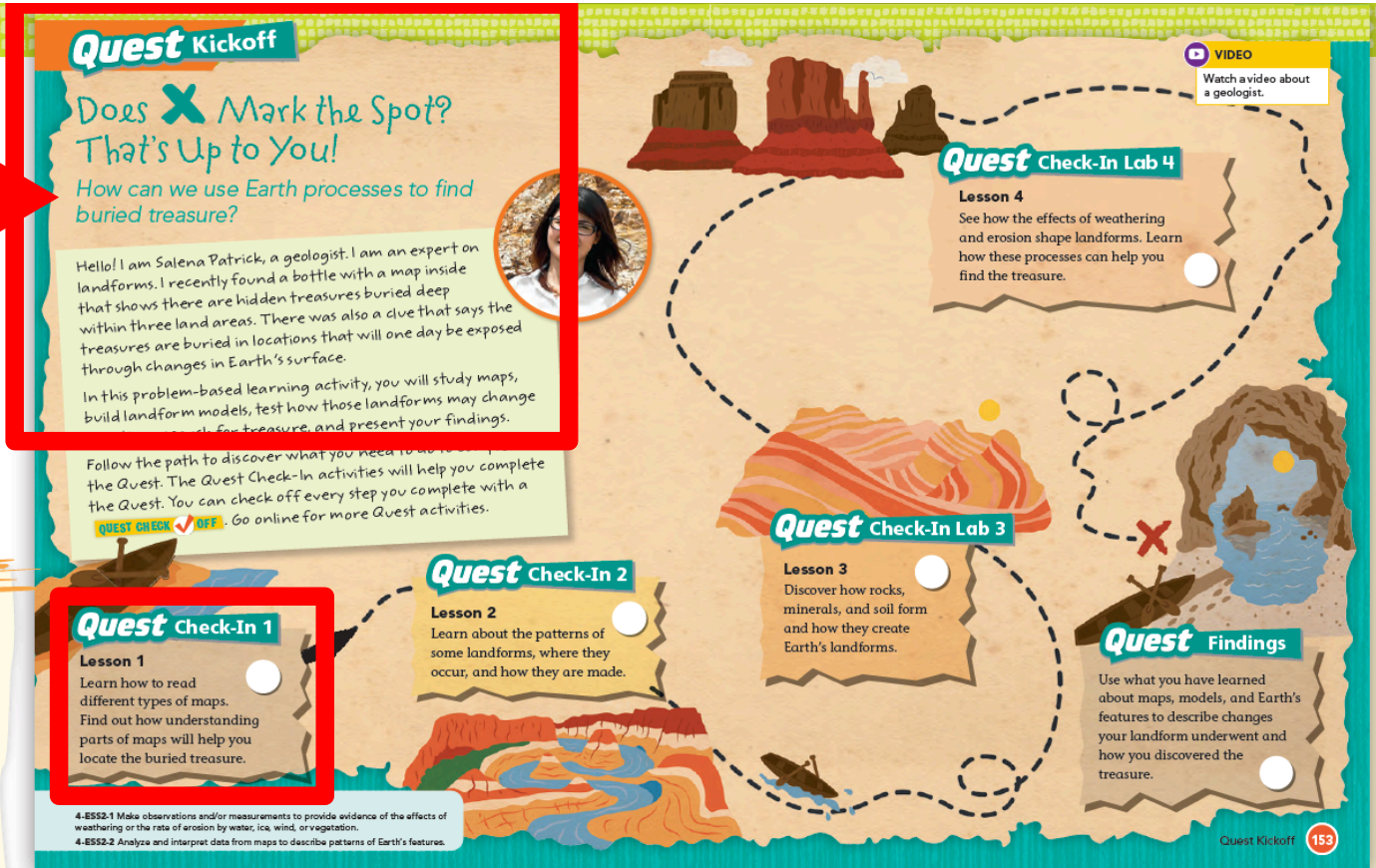

\begin{abstract}
Quest Path
Using Phenomena Quests are problem-based learning projects for students to work on throughout a topic. They help bring the topic content alive for students. By taking on a real-world problem and solving it, students come to understand why it is Quests also provide the opportunity for students to demonstrate mastery of Performance Expectations (PEs), engage in Science and Engineering Practices (SEPs), and interact with Crosscutting Concepts (CCCs) and Disciplinary Core Ideas (DCls).

Encourage students to track their progress by checking off the white circles for each step of the Quest.

- In the Check-In for Lesson 1, students will implement 4-ESS2-2 when they learn how to create a legend, a common map represented on a map as they begin their search for treasure.

- In the Check-In for Lesson 2, students are introduced to the patterns of different landforms. They will practice 4-ESS2-2
\end{abstract} processes of weathering and erosion form new landforms. Understanding these processes will help students find the

- In the Findings, students will plan and produce a presentation that shows how weathering and erosion impact Earth's landforms. They practice 4-ESS2-1, 4-ESS2-2, an EP. 3 when constructing their presentation.

\section{(1) viDe}

Have

What It is Video, short answer prompts, and

What is does Connects the topic career,

geologist, to the Quest project and provides the purpose of the Quest.

How to use it

Have students watch the video to explore the career of a geologist.

- Students will practice following instructions to read a map to determine the location of

buried treasure on the map.

- Then have students complete the screens in
which they ask questions about the Quest.

\section{(1) DOCUMENT}

Have students use the Quest Checklist as a Quest management tool. This tool will help them keep
track of the Quest tasks they have completed.

\section{(-).) DOCUMENT}

The Quest Rubric is a self-assessment tool to help students evaluate their own performance as they complete the Quest project. The rubric also students' performance-based project

\section{(3) INTERACTIVITY}

The Quest Findings digital activity provides students with the opportunity to discover how
landforms are formed and change over time.

- In the Check-In Lab for Lesson 3, students apply ther understanding of rocks, minerals, and soil to discover how the compose Earth's landforms, practicing 4-ESS2-1 and SEP.3.

- In the Check-In Lab for Lesson 4, students explore how the 


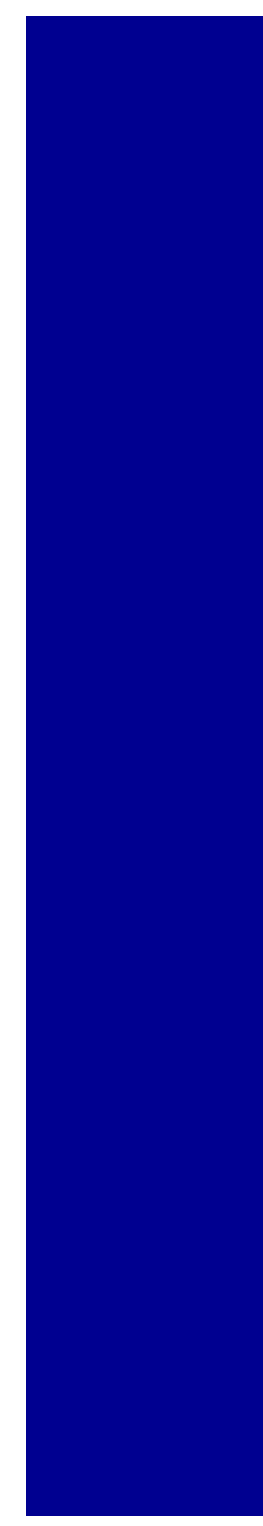

\section{AUPSE Kickoff \\ Does X Mark the Spot? Thats Upto You!}

Using Phenomena Students are introduced to the topic Quest by reading a letter from Salen Patrick, a geologist. The letter explains the work on throughout the Ouest. The art on the path shows different landforms that were formed through Earth's processes. Have students explain how a geologist may use these land features to figure out how land changes over millions of years.

\section{Focus on Mastery}

Analyzing and Interpreting Data Throughout A evidence that will help them explain how Earth's ways that garm and change over time. Discuss the it to better understand Earth's features and how they have been formed and changed over time. Then will students list examples of evidence that an be found throughout the Ouest. Examples include:

- Other scientists's studies

- Observation and study of landform examples - Models of landforms

- Maps from different time periods

Have students share their examples and keep

\section{Next Generation Sclence Standards}

4ESS2.1 Make observations and/or measurements to
provide evidence of the effects of weathering or the rate of

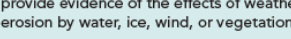

4ESS2-2 Analyze and interpret data from maps to describe

152 Topic 4 Earth's Features

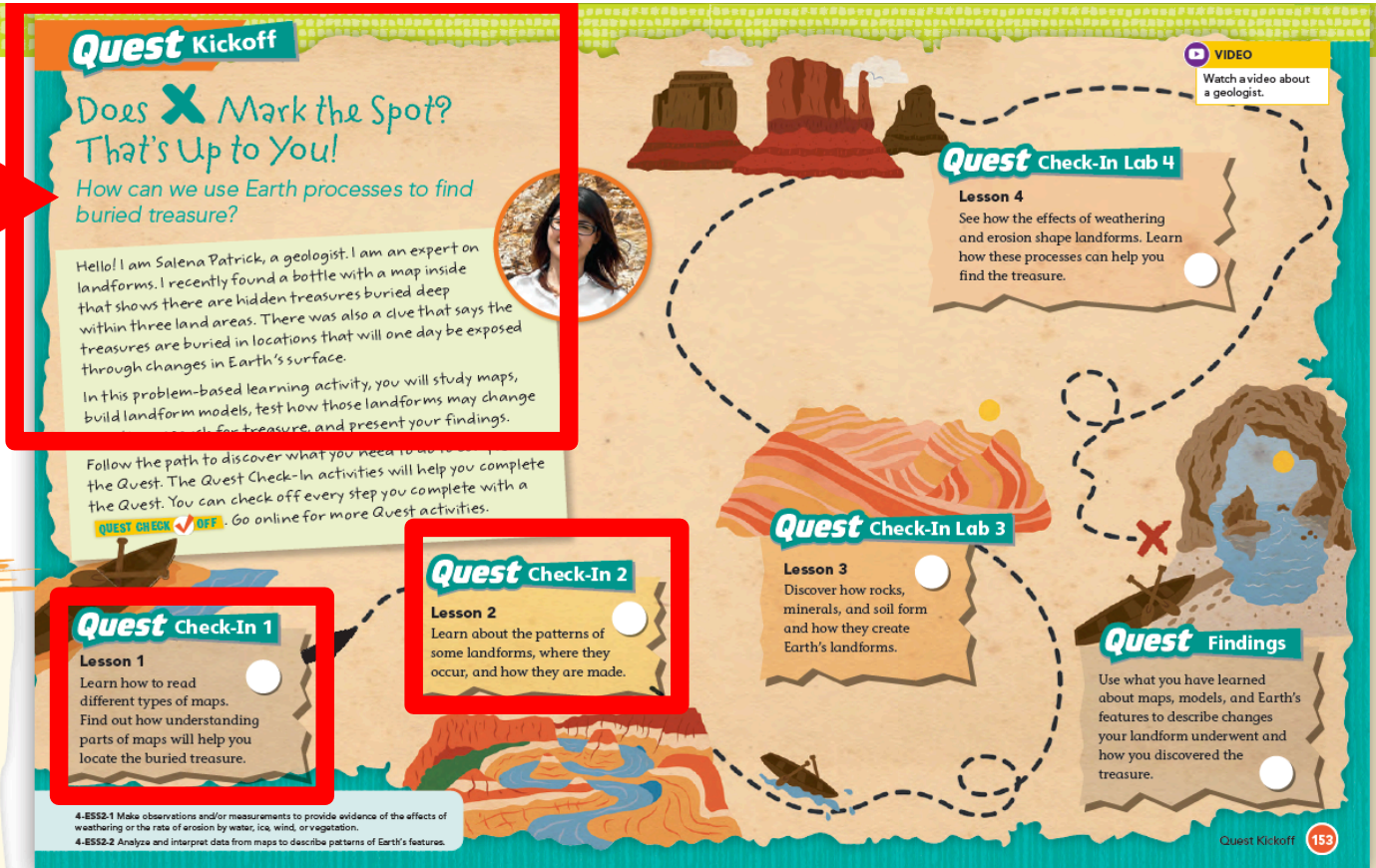

\begin{abstract}
Quest Path
Using Phenomena Quests are problem-based learning projects for students to work on throughout a topic. They help bring the topic content alive for students. By taking on a real-world problem and solving it, students come to understand why it is Quests also provide the opportunity for students to demonstrat mastery of Performance Expectations (PEs), engage in Science and Engineering Practices (SEPs), and interact with Crosscutting Concepts (CCCs) and Disciplinary Core Ideas (DCls).

Encourage students to track their progress by checking off the white circles for each step of the Quest.

- In the Check-In for Lesson 1, students will implement 4-ESS2-2 when they learn how to create a legend, a common map represented on a map as they begin their search for treasure.

- In the Check-In for Lesson 2, students are introduced to the patterns of different landforms. They will practice 4-ESS2-2
\end{abstract}

\section{- In the Check-In Lab for Lesson 3, students apply their understanding of rocks, minerals, and soil to discover how they compose Earth's landforms, practicing 4-ESS2-1 and SEP.3. - In the Check-In Lab for Lesson 4, students explore how the processes of weathering and erosion form new landforms. Understanding these processes will help students find the treasure as they practice 4-ESS2-1 and SEP.3. \\ - In the Findings, students will plan and produce a presentation that shows how weathering and erosion impact Earth's landforms. They practice 4-ESS2-1,
SEP.3 when constructing their presentation. \\ while looking closely at the characteristics of the landforms}

\section{(1) viDe}

Have

What It is Video, short answer prompts, and

What is does Connects the topic career,

geologist, to the Quest project and provides the purpose of the Quest.

How to use it

Have students watch the video to explore the career of a geologist.

- Students will practice following instructions to read a map to determine the location of

buried treasure on the map.

Then have students complete the screens in
which they ask questions about the Quest.

\section{(1) DOCUMENT}

Have students use the Quest Checklist as a Quest management tool. This tool will help them keep
track of the Quest tasks they have completed.

\section{(-).) DOCUMENT}

The Quest Rubric is a self-assessment tool to help students evaluate their own performance as they complete the Quest project. The rubric also srudests you with a consistent way of
students performance-based project

\section{(3) INTERACTIVITY}

The Quest Findings digital activity provides students with the opportunity to discover how
landforms are formed and change over time.

\section{.}




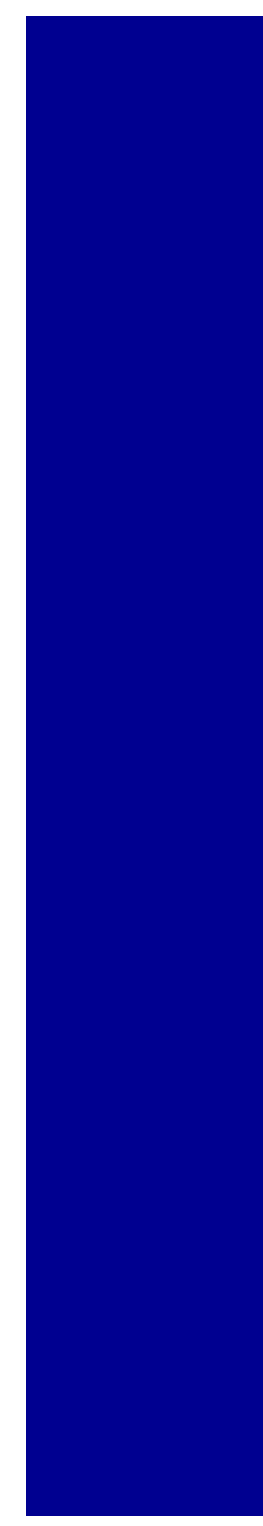

\section{AUPSE Kickoff \\ Does X Mark the Spot? Thats Upto You!}

Using Phenomena Students are introduced to the topic Quest by reading a letter from Salen Patrick, a geologist. The letter explains the work on throughout the Quest. The art 1 the path shows different landforms that were formed through Earth's processes. Have students explain how a geologist may use these land features to figure out how land changes over millions of years.

\section{Focus on Mastery}

Analyzing and Interpreting Data Throughout tudents will use models to gather evidence that will help them explain how Earth's ways that geologists may collect data and analyze it to better understand Earth's features and how they have been formed and changed over time. Then have students list examples of evidence that an be found throughout the Ouest. Examples include:

Other scientists's studies

- Observation and study of landform examples - Models of landforms

- Maps from different time periods

Have students share their examples and keep

Next Generation Sclence Standards 4ESS2-1 Make observations and/or measurements to
provide evidence of the effects of weathering or the rate of erosion by water, ice, wind, or vegetation. 4ESS2-2 Analyze and interpret data from maps to describe 152 Topic 4 Earth's Features

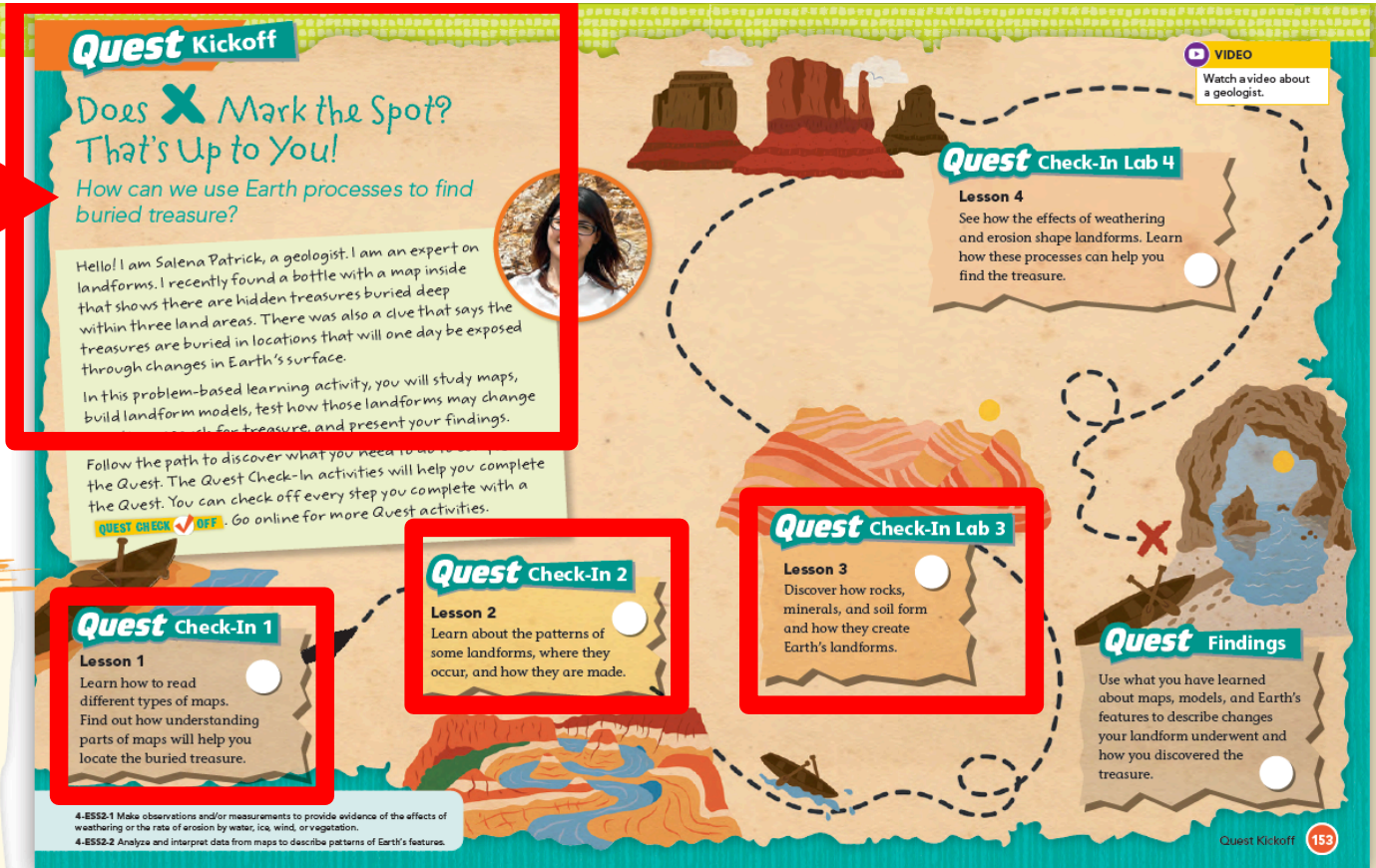

\begin{abstract}
Quest Path
Using Phenomena Quests are problem-based learning projects for students to work on throughout a topic. They help bring the topic content alive for students. By taking on a real-world problem and soling it, students come to understand why it is Quests also provide the opportunity for students to demonstrate mastery of Performance Expectations (PEs), engage in Science and Engineering Practices (SEPs), and interact with Crosscutting Concepts (CCCs) and Disciplinary Core Ideas (DCls).

Encourage students to track their progress by checking off the white circles for each step of the Quest.

- In the Check-In for Lesson 1, students will implement 4-ESS2-2 when they learn how to create a legend, a common map
tool. This will help them think about how land features represented on a map as they begin their search for treasure.

- In the Check-In for Lesson 2, students are introduced to the patterns of different landforms. They will practice 4-ESS2-2
\end{abstract}

processes of weathering and erosion form new landforms.

- In the Findings, students will plan and produce a

presentation that shows how weathering and erosion impact SEP.3 when constructing their presentation. Understanding these processes will help students find the

\section{(1) viDe}

activity.

What It is Video, short answer prompts, and

What is does Connects the topic career,

geologist, to the Quest project and provides the purpose of the Quest.

How to use it

Have students watch the video to explore the career of a geologist.

- Students will practice following instructions to read a map to determine the location of

buried treasure on the map.

Then have students complete the screens in
which they ask questions about the Quest.

\section{(1) DOCUMENT}

Have students use the Quest Checklist as a Quest management tool. This tool will help them keep
track of the Quest tasks they have completed.

\section{(-).) DOCUMENT}

The Quest Rubric is a self-assessment tool to help students evaluate their own performance as they complete the Quest project. The rubric also students' performance-based project.

\section{(3) interactivity}

The Quest Findings digital activity provides students with the opportunity to discover how
landforms are formed and change over time.

- In the Check-In Lab for Lesson 3, students apply ther understanding of rocks, minerals, and soil to discover how the compose Earth's landforms, practicing 4-ESS2-1 and SEP.3. - In the Check-In Lab for Lesson 4, students explore how the

\section{.}




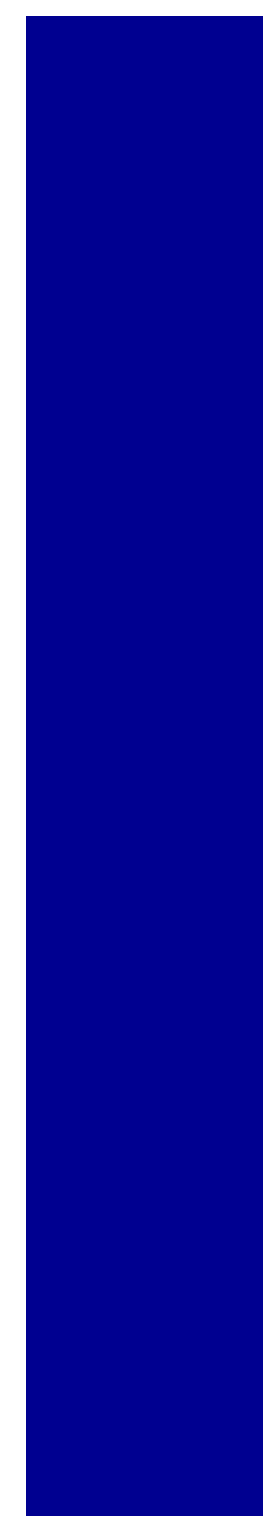

\section{AUPSE Kickoff \\ Does X Mark the Spot? Thats Upto You!}

Using Phenomena Students are introduced to the topic Quest by reading a letter from Salen Patrick, a geologist. The letter explains the work on throughout the Quest. The art 1 the path shows different landforms that were formed through Earth's processes. Have students explain how a geologist may use these land features to

\section{Focus on Mastery}

Analyzing and Interpreting Data Throughout the Quest, students will use models to gather evidence that will help them explain how Earth's
features form and change over time. Discuss the ways that geologists may collect data and analyze it to better understand Earth's features and how they have been formed and changed over time. they will need to analyze how buried trence th can be found throughout the Quest. Examples include:

Other scientists's studies

- observation and study of landform examples - Models of landforms

- Maps from different time periods

Have students share their examples and keep

Next Generation Sclence Standards 4ESS2-1 Make observations and/or measurements to
provide evidence of the effects of weathering or the rate of erosion by water, ice, wind, or vegetation. 4ESS2-2 Analyze and interpret data from maps to describe 152 Topic 4 Earth's Features

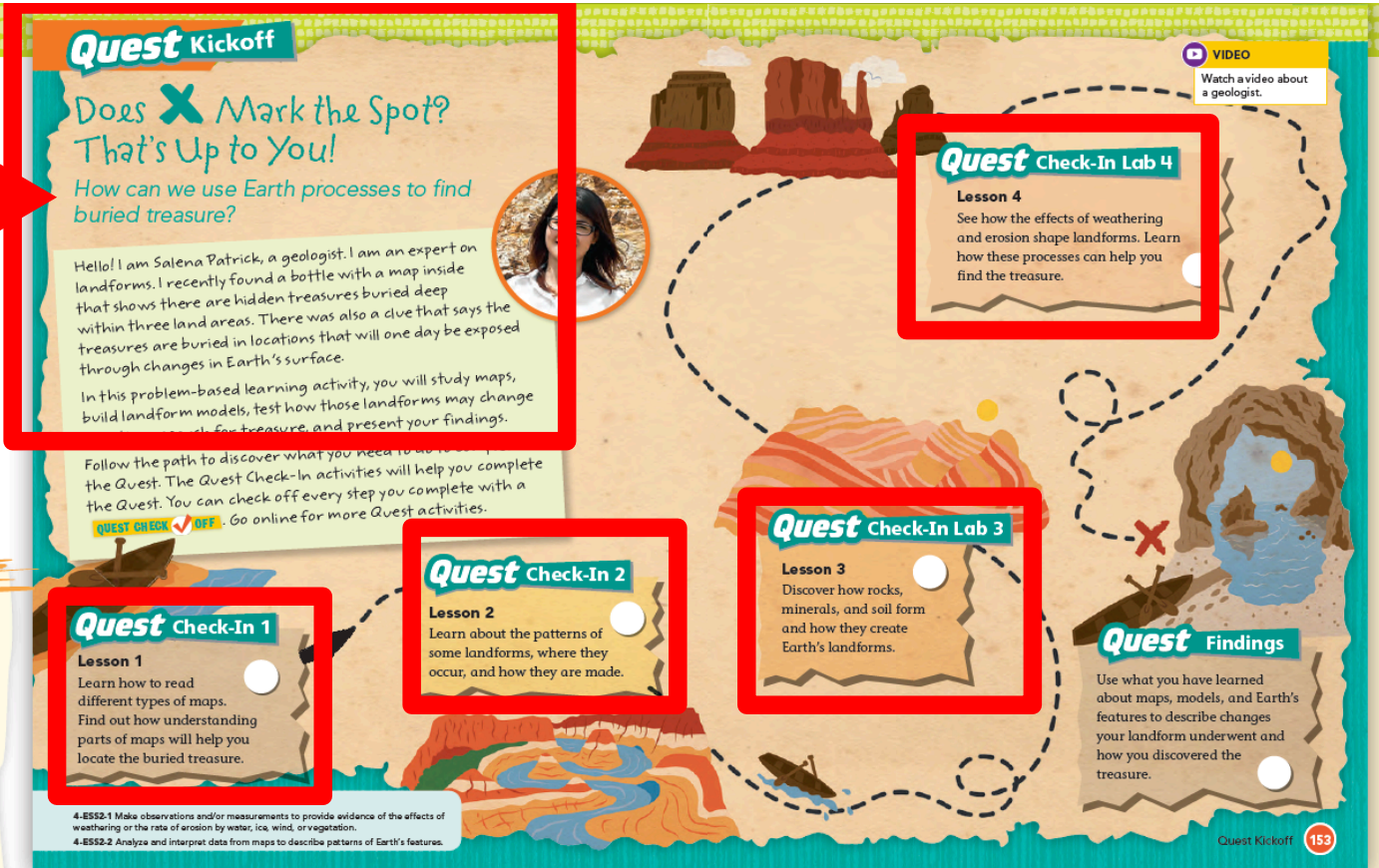

\begin{abstract}
Quest Path
Using Phenomena Quests are problem-based learning projects for students to work on throughout a topic. They help bring the topic content alive for students. By taking on a real-world problem and solving it, students come to understand why it is Quests also provide the opportunity for students to demonstrat mastery of Performance Expectations (PEs), engage in Science and Engineering Practices (SEPs), and interact with Crosscutting Concepts (CCCs) and Disciplinary Core Ideas (DCls).

Encourage students to track their progress by checking off the white circles for each step of the Quest.

- In the Check-In for Lesson 1, students will implement 4-ESS2-2 when they learn how to create a legend, a common map
tool. This will help them think about how land features are represented on a map as they begin their search for treasure.

- In the Check-In for Lesson 2, students are introduced to the patterns of different landforms. They will practice 4-ESS2-2
\end{abstract}

\section{- In the Check-In Lab for Lesson 3, students apply ther understanding of rocks, minerals, and soil to discover how they compose Earth's landforms, practicing 4-ESS2-1 and SEP.3. \\ - In the Check-In Lab for Lesson 4, students explore how the processes of weathering and erosion form new landforms. Understanding these processes will help students find the \\ - In the Findings, students will plan and produce a presentation that shows how weathering and erosion impact
Earth's landforms. They practice 4-ESS2-1, 4-ESS2-2, and SEP.3 when constructing their presentation. \\ while looking closely at the characteristics of the landforms}

\section{(1) VIDEO}

activity.

What It is Video, short answer prompts, and

What is does Connects the topic career, a geologist, to the Quest project and provides the purpose of the Quest.

How to use it

Have students watch the video to explore the career of a geologist.

- Students will practice following instructions to read a map to determine the location of

buried treasure on the map.

Then have students complete the screens in
which they ask questions about the Quest.

\section{(). DOCUMENT}

Have students use the Quest Checklist as a Quest management tool. This tool will help them keep

\section{(-).) DOCUMENT}

The Quest Rubric is a self-assessment tool to help students evaluate their own performance as they complete the Quest project. The rubric also students' performance-based project
stovide

\section{(3) INTERACTIVITY}

The Quest Findings digital activity provides students with the opportunity to discover how

\section{.}




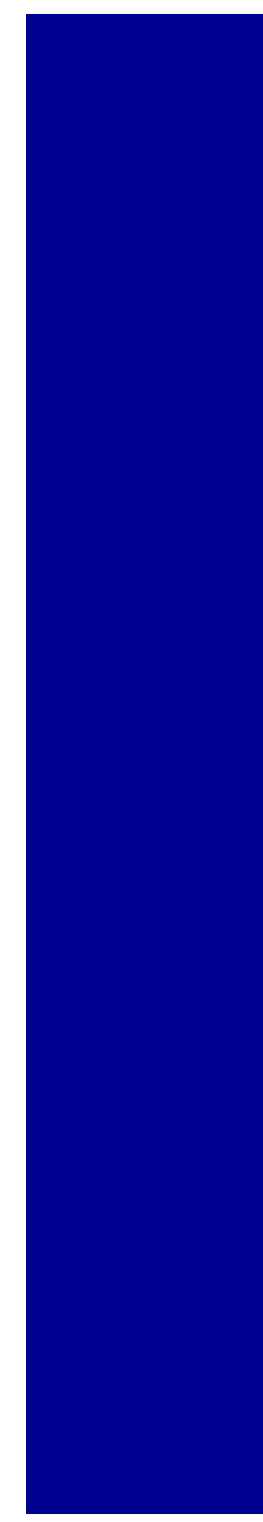

\section{AUPSE Kickoff \\ Does X Mark the Spot? Thats Upto You!}

Using Phenomena Students are introduced to the topic Quest by reading a letter from Salen Patrick, a geologist. The letter explains the work on throughout the Quest. The art 1 the path shows different landforms that were formed through Earth's processes. Have students explain how a geologist may use these land features to

\section{Focus on Mastery}

Analyzing and Interpreting Data Throughout the Quest, students will use models to gather the Quest, students will use models to gather
evidence that will help them explain how Earth's features form and change over time. Discuss the ways that geologists may collect data and analyze it to better understand Earth's features and how they have been formed and changed over time. Then have students list examples of evidence th an be found throughout the Ouest. Examples include:

- Other scientists' studies

- Observation and study of landform examples - Models of landforms

- Maps from different time periods

Have students share their examples and keep

\section{Next Generation Sclence Standards}

4ESS2.1 Make observations and or measurements to
provide evidence of the effects of weathering or the rate of provide evidence or the effects of weat
erosion by water, ice, wind, or vegetation.

4ESS2-2 Analyze and interpret data from maps to describe

152 Topic 4 Earth's Features

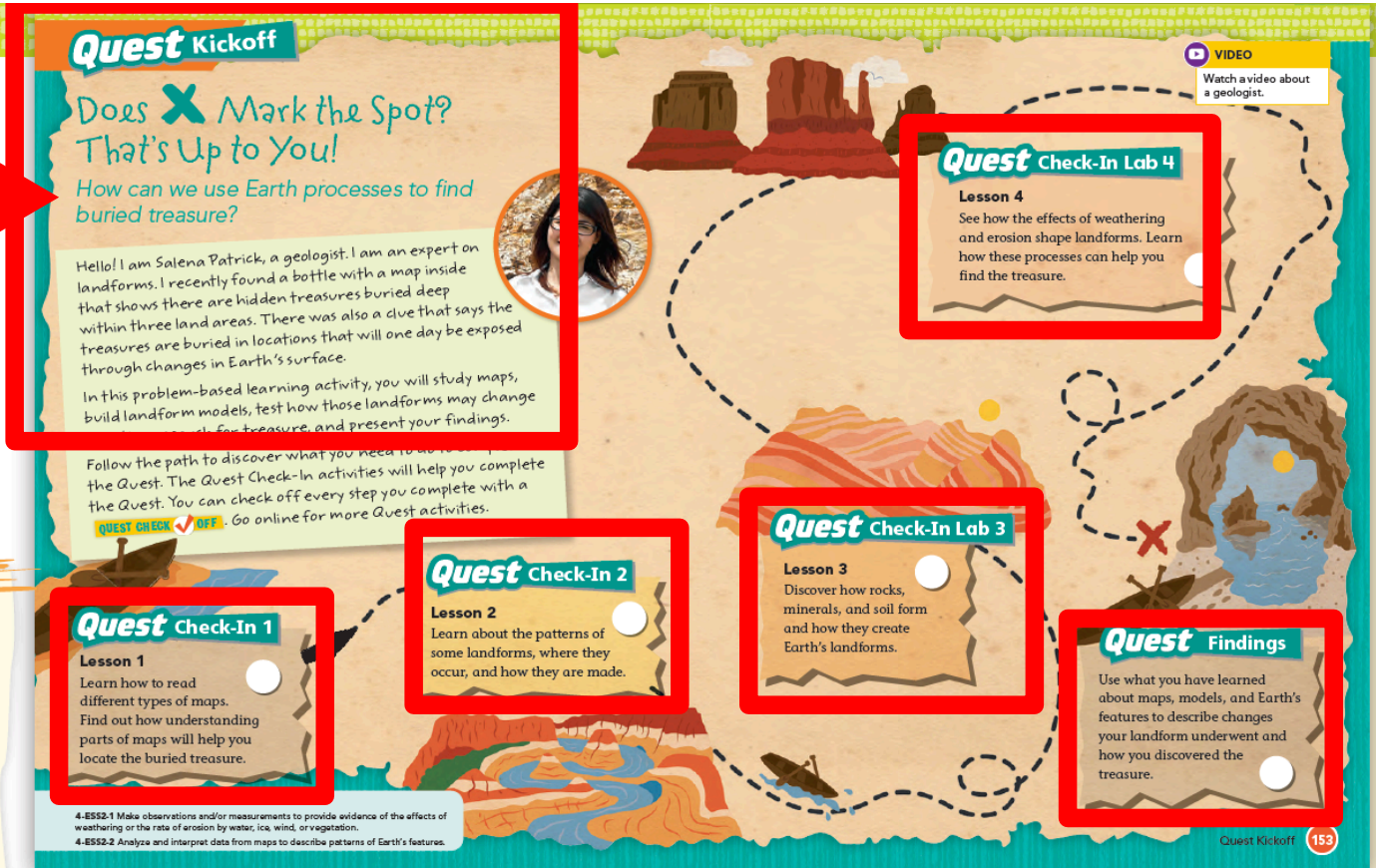

\begin{abstract}
Quest Path
Using Phenomena Quests are problem-based learning projects for students to work on throughout a topic. They help bring the topic content alive for students. By taking on a real-world problem and soling it, students come to understand why it is Quests also provide the opportunity for students to demonstrat mastery of Performance Expectations (PEs), engage in Science and Engineering Practices (SEPs), and interact with Crosscutting Concepts (CCCs) and Disciplinary Core Ideas (DCls).

Encourage students to track their progress by checking off the white circles for each step of the Quest.

- In the Check-In for Lesson 1, students will implement 4-ESS2-2 when they learn how to create a legend, a common map
tool. This will help them think about how land features ar represented on a map as they begin their search for treasure.

- In the Check-In for Lesson 2, students are introduced to the patterns of different landforms. They will practice 4-ESS2-2
\end{abstract}

- In the Check-In Lab for Lesson 3, students apply their understanding of rocks, minerals, and soil to discover how they compose Earth's landforms, practicing 4-ESS2-1 and SEP.3. - In the Check-In Lab for Lesson 4, students explore how the processes of weathering and erosion form new landforms. Understanding these processes will help students find the treasure as they practice 4-ESS2-1 and SEP.3.

- In the Findings, students will plan and produce a presentation that shows how weathering and erosion impact SEP.3 when constructing their presentation.

\section{(1) viDe}

activity.

What It is Video, short answer prompts, and

What is does Connects the topic career, a geologist, to the Quest project and provides the purpose of the Quest.

How to use it

Have students watch the video to explore the career of a geologist.

- Students will practice following instructions to read a map to determine the location of

buried treasure on the map.

- Then have students complete the screens in

\section{(1) DOCUMENT}

Have students use the Quest Checklist as a Quest management tool. This tool will help them keep

(⿹). DOCUMENT

The Quest Rubric is a self-assessment tool to The Quest Rubric is a self-assessment tool to
help students evaluate their own performance as they complete the Quest project. The rubric also provides you with a consistent way of evaluating students' performance-based project.

\section{(3) InTERActivitY}

The Quest Findings digital activity provides students with the opportunity to discover how landforms are formed and change over time. 

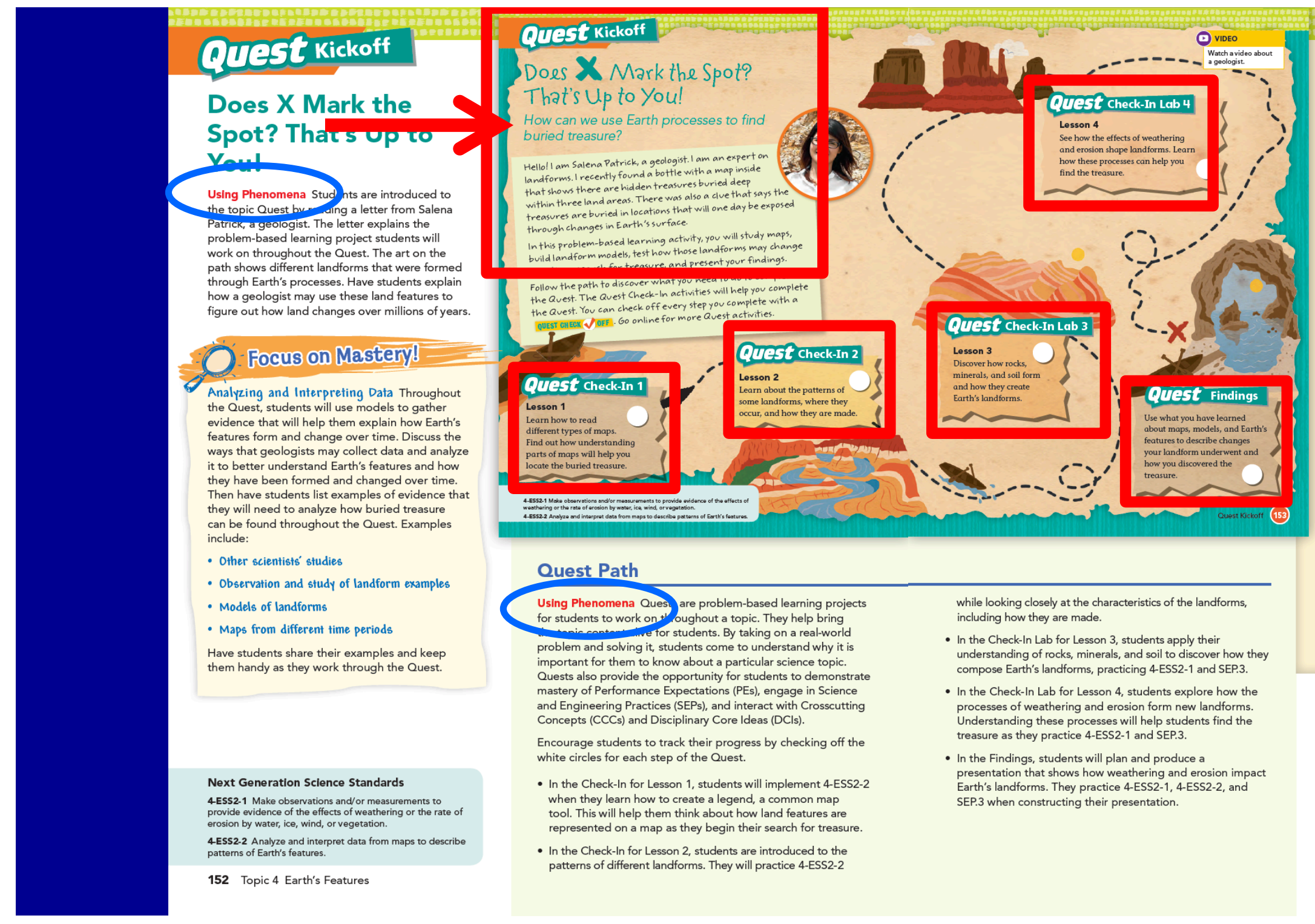

- Other scientists' studies

- Observation and study of landform examples

- Models of landforms

- Maps from different time periods

Have students share their examples and keep
them handy as they work through the Quest.

the

Next Generation Sclence Standards

4ESS2.1 Make observations and/or measurements to
provide evidence of the effects of weathering or the rate of
erosion by water, ice, wind, or vegetation.

4ESS2-2 Analyze and interpret data from maps to describe
patterns of Earth's features.

152 Topic 4 Earth's Features

\section{(-) VIDEo}

activity.

What it is Video, short answer prompts, and

interactive screens

What is does Connects the topic career, a

geologist, to the Quest project and provides the

geologist, to the Quest
purpose of the Quest

How to use it

Have students watch the video to explore the

career of a geologist.

- Students will practice following instructions to read a map to determine the location of

buried treasure on the map.

Then have students complete the screens in
which they ask questions about the Quest.

\section{궁 oocumerr}

Have students use the Quest Checklist as a Quest management tool. This tool will help them keep

\section{(1) DOCUMENT}

The Quest Rubric is a self-assessment tool to help students evaluate their own performance as they complete the Quest project. The rubric also students' performance-based project.

\section{Quest Path}

Using Phenomena Ques, are problem-based learning projects for students to work on ty oughout a topic. They help bring

problem and solving it, students come to understand why it is important for them to know about a particular science topic. Quests also provide the opportunity for students to demonstrate mastery of Performance Expectations (PEs), engage in Science Concepts (CCCs) and Disciplinary Core Ideas (DCls).

Encourage students to track their progress by checking off the

- In the Check-In for Lesson 1, students will implement 4-ESS2-2 when they learn how to create a legend, a common map
tool. This will help them think about how land features are represented on a map as they begin their search for treasure.

- In the Check-In for Lesson 2, students are introduced to the

\section{(3) INTERACTIVITY}

while looking closely at the characteristics of the landforms, including how they are made.

- In the Check-In Lab for Lesson 3, students apply their compose Earth's landforms, practicing 4-ESS2-1 and SEP.3.

- In the Check-In Lab for Lesson 4, students explore how the Processes of weathering and erosion form new landforms. Understanding these processes will help stud
treasure as they practice 4-ESS2-1 and SEP.3.

- In the Findings, students will plan and produce a

presentation that shows how weathering and erosion impac Earth's landforms. They practice 4-ESS2-1, 4-ESS2-2, and SEP.3 when constructing their presentation.
The Quest Findings digital activity provides andforms are formed and change over time. 


\section{QUEST}

\section{connections}

in each lesson

of each chapter:

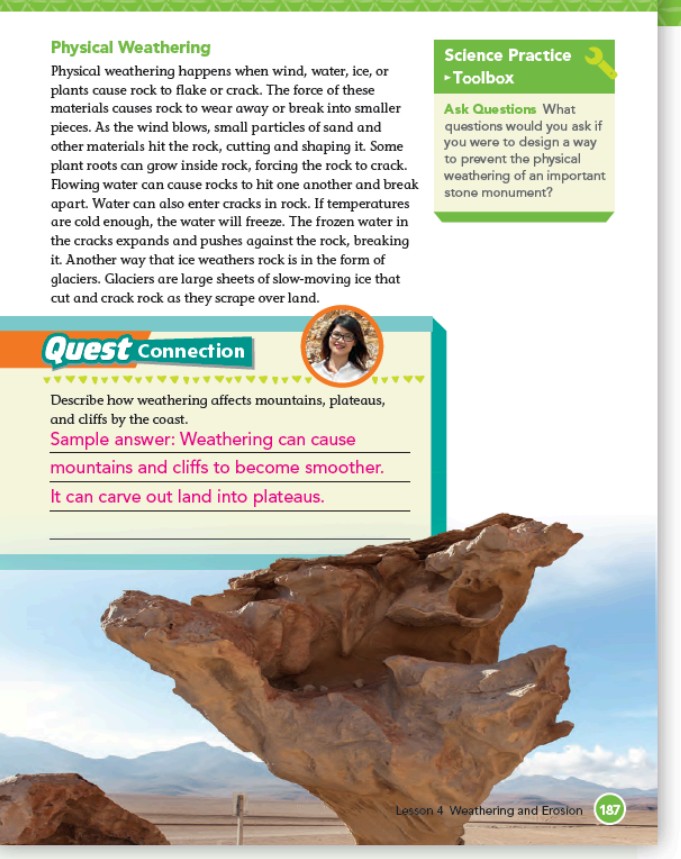

Possible Misconception

\section{Weathering}

Students may think that physical weathering occurs in a short amount of time. For example, if water freezes in a rock's crack
overnight and then melts the next day, the rock will likely overnight and then melts the next day, the rock will likely
not crack apart immediately. Address this misconception by reminding students that weathering occurs over a long period crack over a length of months or even years will most likely break apart a rock. Have students think of examples of physical weathering that they have seen, such as potholes in streets during the spring melt, plants growing in cracks in rocks, or weathered shells found along a shoreline.

Science Practice - Toolbox 2 Ask Questions Have students discuss how

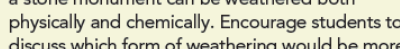
discuss which form of weathering would be more crucial to prevent. Have students propose their
questions with support, and guide students to questions with support, and
critique each other's ideas.

\section{Scaffolded Questions}

Use the following questions to assess students' Recall What causes physical weathering? DOK1 or plants.

Relate Describe ways wind and water ac together to cause weathering. DOK2 (Wind blows washes the particles away)

Formulate Think of an example in which chemical rock has been subjected to chemically weethered rain over the years, causing it to become pitted. It has also been subjected to excessive water that caused the rock to crack.

\section{QUESE Connection}

- Preview that students will be planning and their understanding of weathering using their landform model in the upcoming Quest Check-In Lab.

- Review that weathering is the process that wears away or breaks down rock. Talk about how weathering likely impacts landforms.

- Have students discuss how physical weathering and chemical weathering are related. Encourage students to discuss how weathering is related to
their landform model. 


\section{QUEST}

\section{connections}

in each lesson

of each chapter:

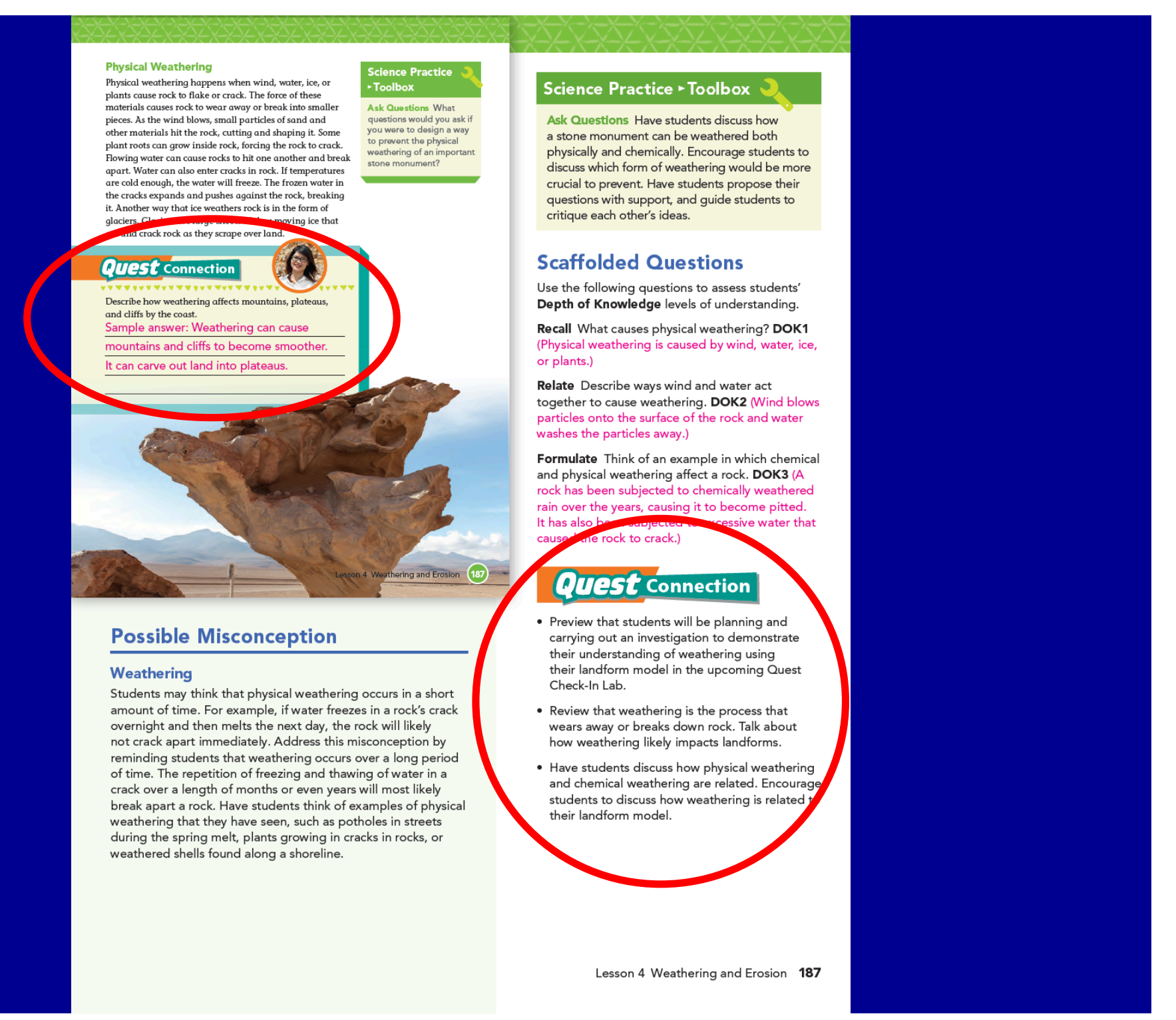




\section{Any NGSS-designed Curricular Materials Should Incorporate the Five "NGSS Innovations"}

1. Three-Dimensional Learning

2. Building K-12 Progressions

3. Alignment with Common Core English Language Arts and Mathematics

4. Making Sense of Phenomena and Designing Solutions to Problems

5. All Standards, All Students 


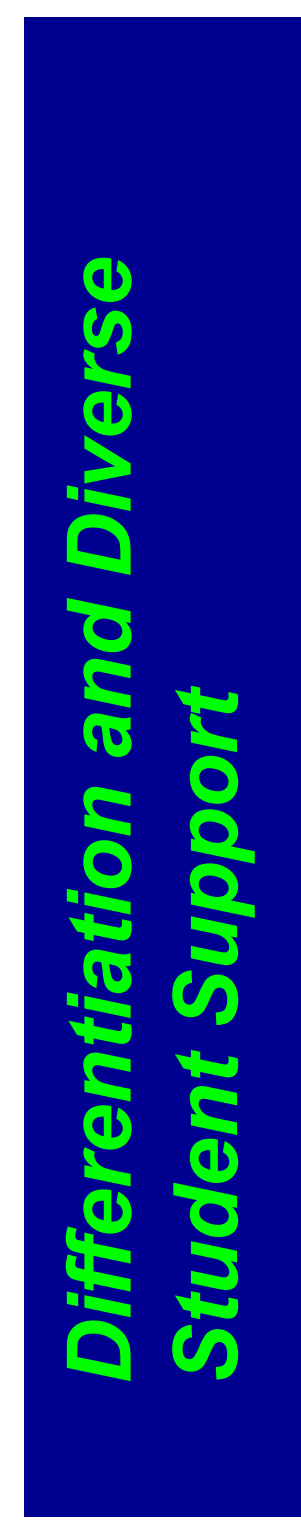

Visual Literacy Connection
INVESTIGATE
(1) viRTuAL LAB
Students will use a street map, a physical map,
and a topographic map to choose the best
location to place atelescope. Go online to find
the detailed teacher support document for the
activity.

Teach with Visuals

Before students begin reading the visual, ask
them: What do the images tell you about thow you them: What do the images tell you about
can see the same place in different ways?

- Model how to compare the features shown on each map. Use the area near the Golden Gate area on all three maps. - Ask students to look closely to see what
features make each map similar or different from the other maps.

- Discuss how the maps provide visual different ways.

Visual Literacy Connection

How can you see the Same place in different ways?

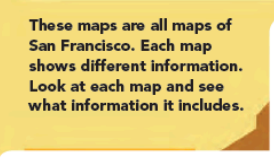

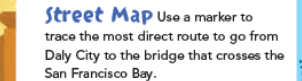

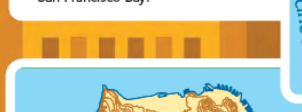

$$
\text { Ansons }
$$
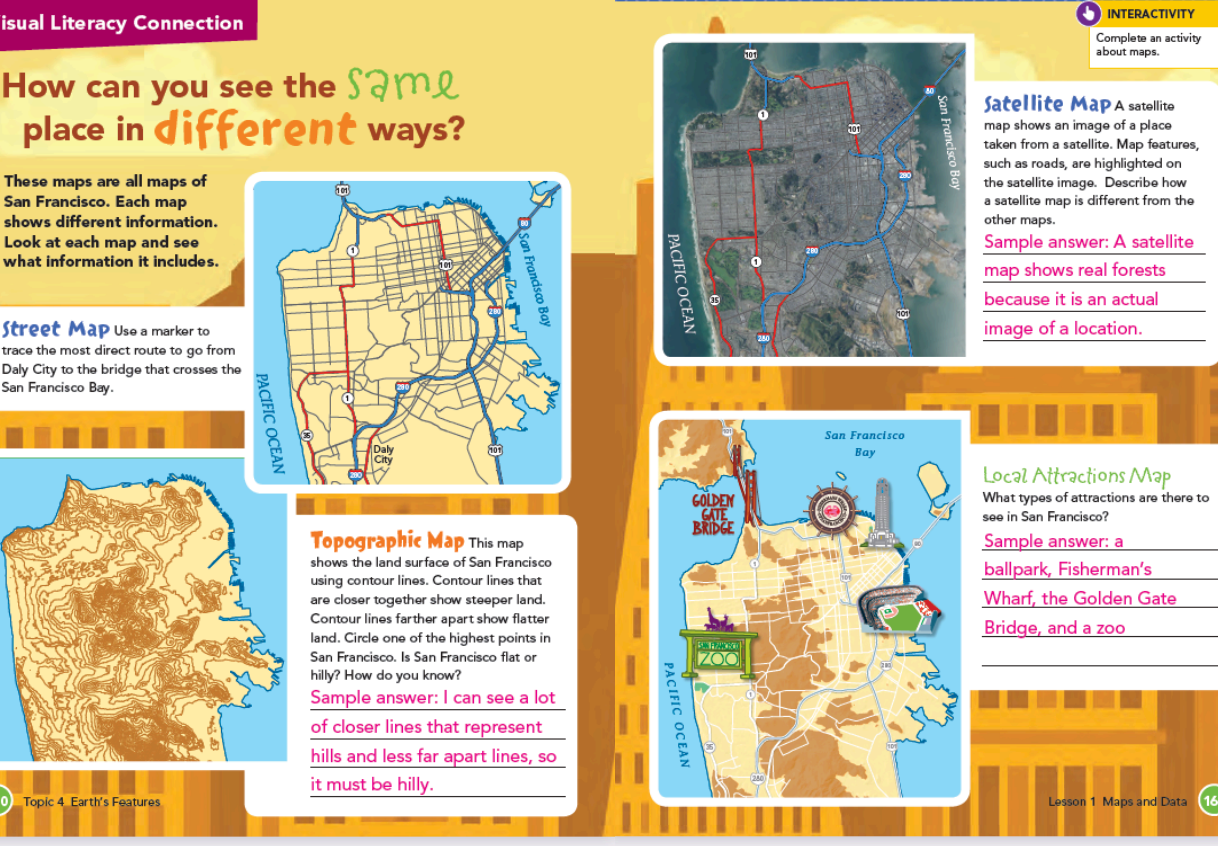

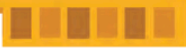

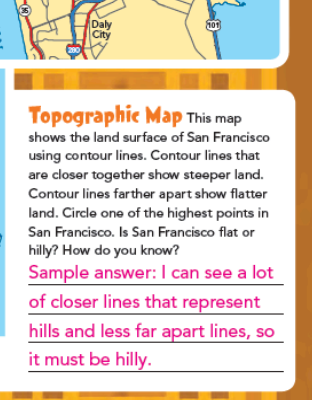

\section{Differentiated Instruction}

\section{Support Struggling Students}

Have students work with a partner to find the Pacific Ocean on one of the maps. Then have them label the Pacific Ocean on the topographic map. Be sure students understand that

although the three maps show different features of an area,
they all still show the same location.

Support Advanced Learners

Challenge advanced learners to research two different maps of their hometown. Ask them to compare these maps and draw conclusions about how certain types of maps serve different purposes. maps and data to understand the various land

- City tour guides would use attractions maps to guide tourists from location to location.

- Have students consider professions that would use street maps of San Francisco. Ask them to explain why those professions would need to use street maps rather than other types of

160 Topic 4 Earth's Features

\section{SYNTHESIZE}

\section{(5) InTERActivity}

Have students complete the Synthesize Activity.

What it is Real world scenario-based

interactivities and engaging images

What it does Supports students in synthesizing and applying what they've learned throughout the lesson How to use it

- Students will click through the screens to explore the features of various types of maps.

\section{(1).) DOCUMENT}

Assign the Enrichment Activity to have students practice map skills by creating three differen

\section{Scaffolded Questions}

Use the following questions to assess students

Identify Choose the map you would use to find your way from the airport to the Golden Gate Bridge. Explain why this map would help you with
this task. DOK1 (The street map will provide the names of streets for a route I can take to get to the Golden Gate Bridge.)

Summarize Relate the topographic map to the local attractions map. What information do you gain by using both together? DOK2 (The lopol features in the area, while the local attraent map shows the man-made features of the area? By looking at both maps together, I am able to understand which attractions are located on hills in San Francisco and which are closer to sea level.) Formulate Think about where you live. Which of these maps would be used most by the people in your community? Explain your reasoning. DOK3
(Answers will vary, but students will consider (Answers will vary, but students will consider whether their community has many attractions or the area, a road map may be most used by people in the community.)
Bridging Have students identify whether each attraction is

located in a flat or hilly section of San Francisco. 


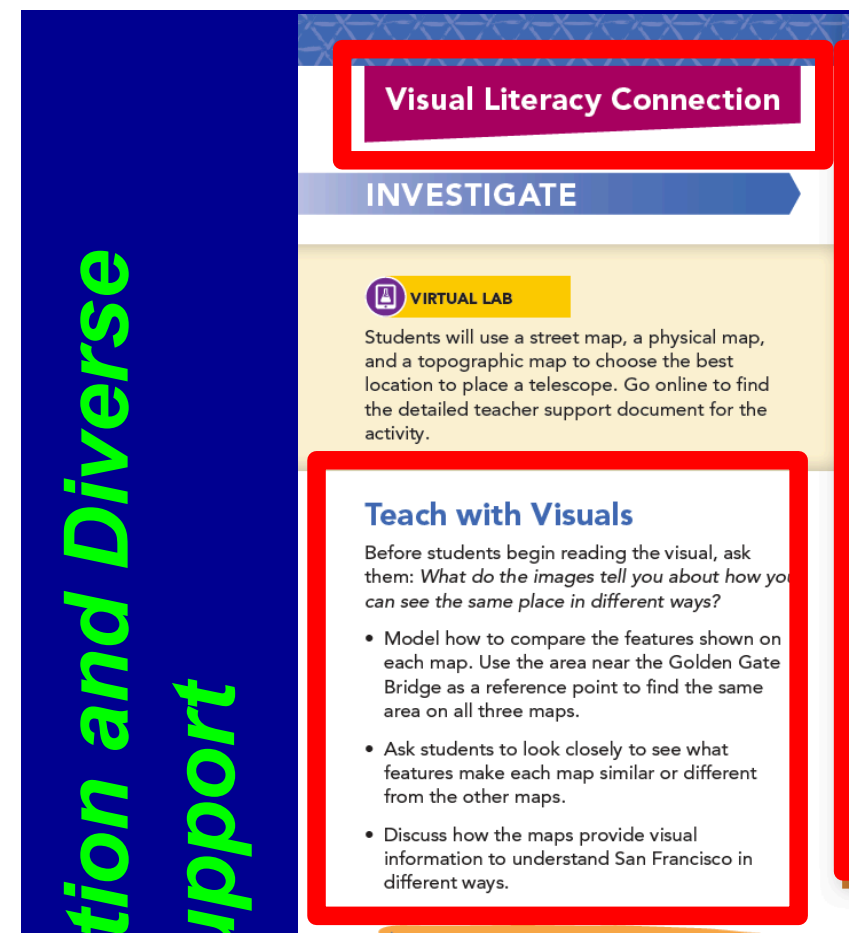

0 Focus on Mastery!

Analkzing and Interpreting Data Explain that maps are made for different purposess. Guide students to think about what professions
find each type of map the most useful.

- Environmental scientists would use topographic maps and data to understand the various land

- City tour guides would use attractions maps to guide tourists from location to location.

- Have students consider professions that would use street maps of San Francisco. Ask them to explain why those professions would need to use street maps rather than other types of

160 Topic 4 Earth's Features

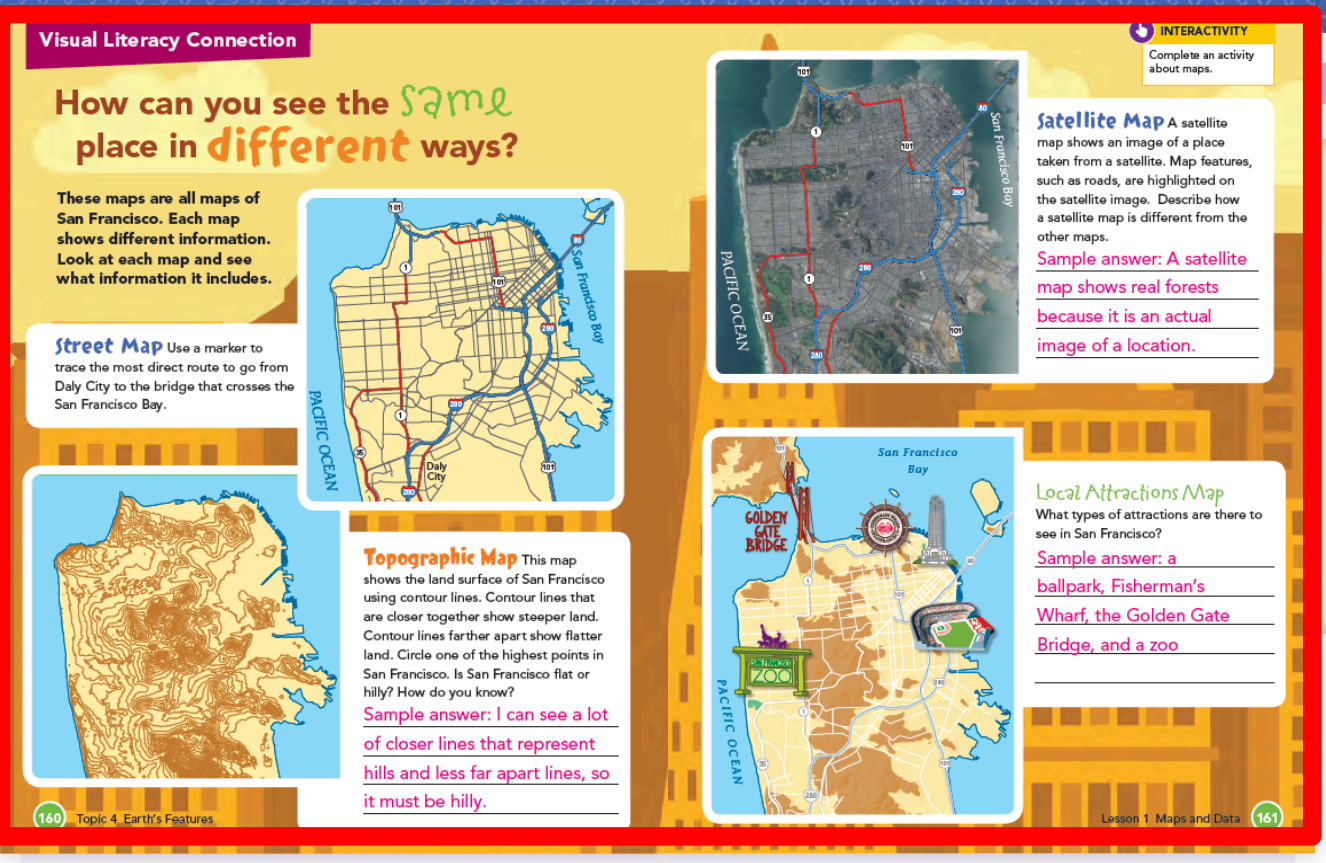

\section{Differentiated Instruction}

\section{Support Struggling Students}

Have students work with a partner to find the Pacific Ocean on one of the maps. Then have them label the Pacific Ocean on the topographic map. Be sure students understand that although the three maps show different features of an area.

Support Advanced Learners

Challenge advanced learners to research two different maps of their hometown. Ask them to compare these maps and draw parpses. purposes.
ELD Support

Speaking Use the text and images in the Visual Literacy Connection to help students practice their English vocabulary.

Entering Have students say the name of the city and state

sented in the visual.

Beginning Have students take turns telling whether San is flat or hilly.

Developing Have students use examples from the map to

Expanding Have students use details to prove whether San Francisco is flat or hilly.

Bridging Have students identify whether each attraction is

located in a flat or hilly section of San Francisco.

\section{SYNTHESIZE}

\section{(3) INTERACTVITY}

Have students complete the Synthesize Activity.

What it is Real world scenario-based

interactivities and engaging images

What it does Supports students in synthesizing and

applying what they've learned throughout the lesson

How to use it

- Students will click through the screens to explore the features of various types of maps.

\section{(1).) DOCUMENT}

Assign the Enrichment Activity to have students practice map skills by creating three differen
types of maps of their neighborhood.

\section{Scaffolded Questions}

Use the following questions to assess students' Depth of Knowledge levels of understanding.

Identify Choose the map you would use to find your way from the airport to the Golden Gate Bridge. Explain why this map would help you with this task. DOK1 (The street map will provide the names of streets for a route I can take to get to the Golden Gate Bridge.)

Summarize Relate the topographic map to the local attractions map. What information do you gain by using both together? DOK2 (The land feaptices in the rea, while thion of different map shows the man-made features of the area. By looking at both maps together, I am able to understand which attractions are located on hills in San Francisco and which are closer to sea level.) Formulate Think about where you live. Which of these maps would be used most by the people in your community? Explain your reasoning. DOK3
(Answers will vary, but students will consider (Answers will vary, but students will consider whether their community has many attractions or the area, a road map may be most used by people in the community.) 


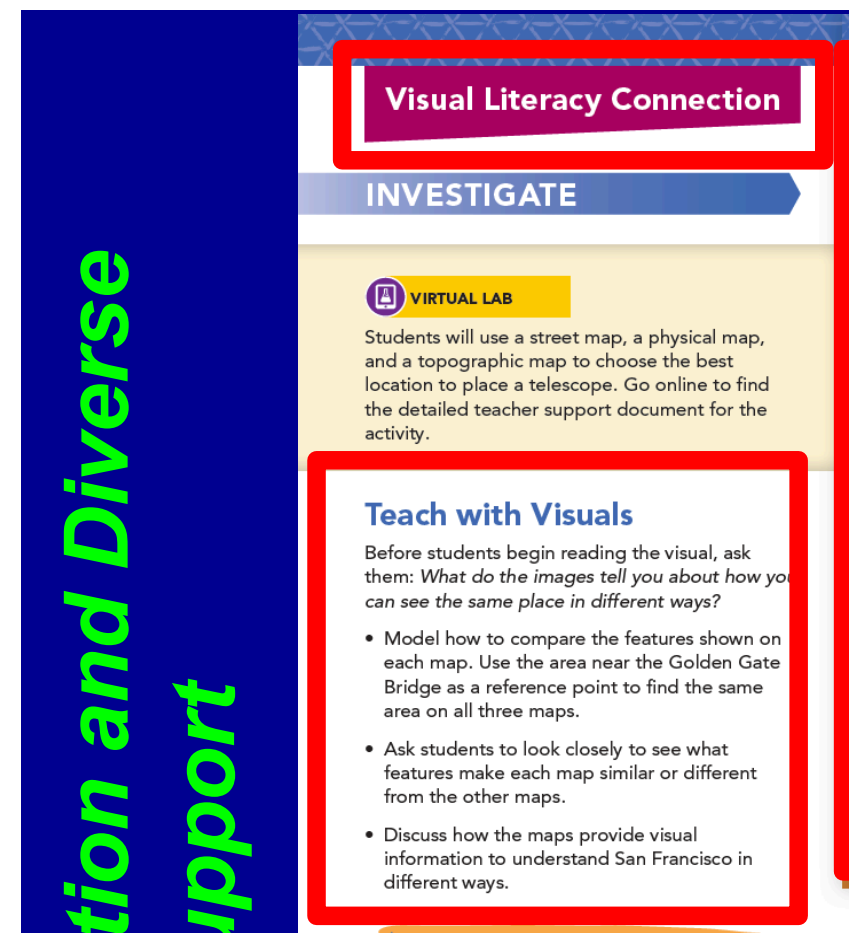

0 Focus on Mastery!

Analkzing and Interpreting Data Explain that maps are made for difierent purposess. Guide students to think about what professions
find each type of map the most useful.

- Environmental scientists would use topographic maps and data to und

- City tour guides would use attractions maps to guide tourists from location to location.

- Have students consider professions that would use street maps of San Francisco. Ask them to explain why those professions would need to use street maps rather than other types of

160 Topic 4 Earth's Features

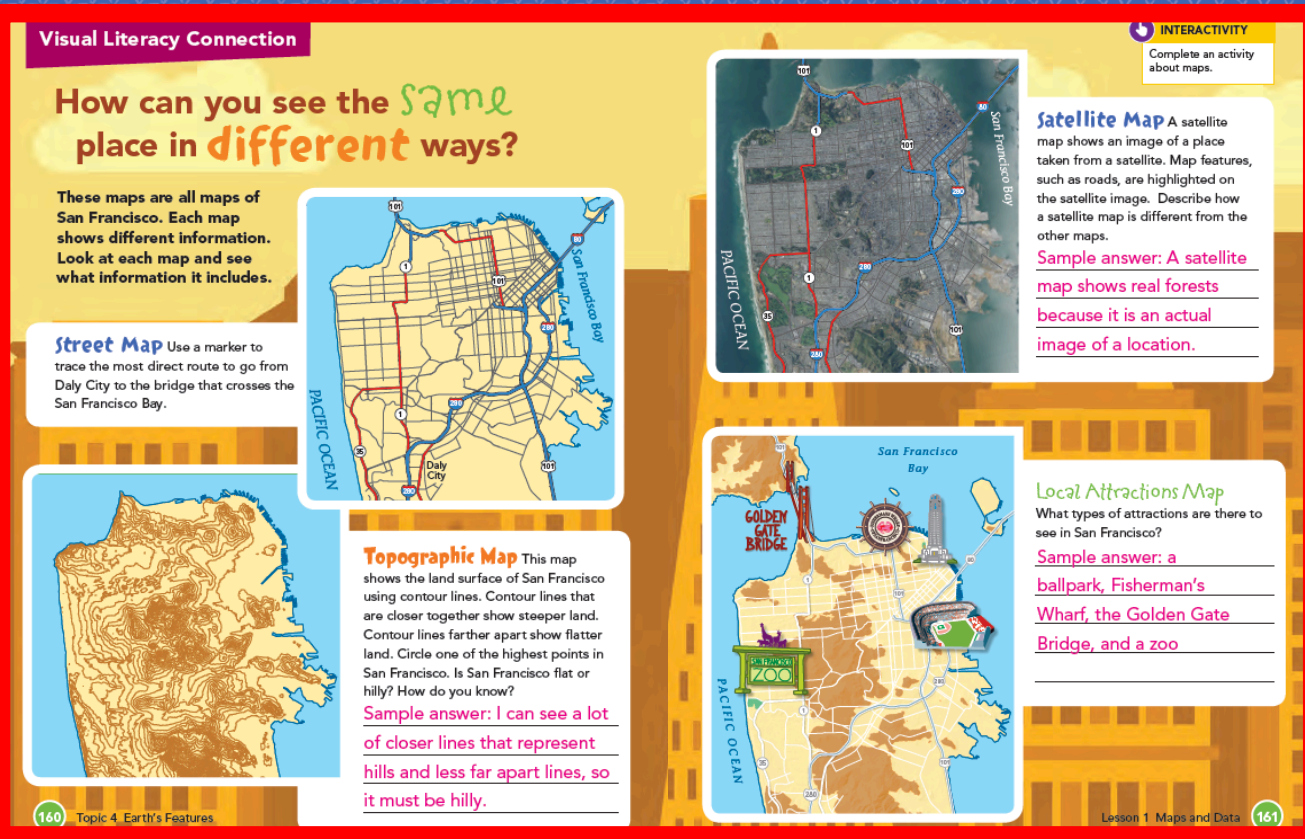

\section{Differentiated Instruction}

\section{Support Struggling Students}

Have students work with a partner to find the Pacific Ocean on one of the maps. Then have them label the Pacific Ocean on the topographic map. Be sure students understand that although the three maps show different features of an are

Support Advanced Learners

Challenge advanced learners to research two different maps of their hometown. Ask them to compare these maps and draw conclusions about how certain types of maps serve different purposes.
ELD Support

Speaking Use the text and images in the Visual Literacy Connection to help students practice their English vocabulary.

Entering Have students say the name of the city and state

sented in the visual.

Beginning Have students take turns telling whether San co is flat or hilly.

Developing Have students use examples from the map to

Expanding Have students use details to prove whether San Francisco is flat or hilly. Bridging Have students identity whether each attrat
located in a flat or hilly section of San Francisco.

\section{SYNTHESIZE}

\section{(b) INTERACTIVITY}

Have students complete the Synthesize Activity.

What it is Real world scenario-based

interactivities and engaging images

What it does Supports students in synthesizing and

applying what they've learned throughout the lesson

How to use it

- Students will click through the screens to explore the features of various types of maps.

\section{(․).) DOCUMENT}

Assign the Enrichment Activity to have students practice map skills by creating three different
types of maps of their neighborhood.

Scaffolded Questions Use the following questions to assess students Depth of Knowledge levels of understanding. Identify Choose the map you would use to find your way from the airport to the Golden Gate your way from the airport to the Golden Gate
Bridge. Explain why this map would help you with this task. DOK1 (The street map will provide the names of streets for a rou
the Golden Gate Bridge.)

Summarize Relate the topographic map to the local attractions map. What information do you gain by using both together? DOK2 (The lopord faphic map shows the elevation of different map shows the man-made features of the area By looking at both maps together, I am able to understand which attractions are located on hills in San Francisco and which are closer to sea level.)

Formulate Think about where you live. Which of these maps would be used most by the people in your community? Explain your reasoning. DOK
(Answers will vary, but students will consider whether their community has many attractions or varying topography. Depending on the features of in the community.) 


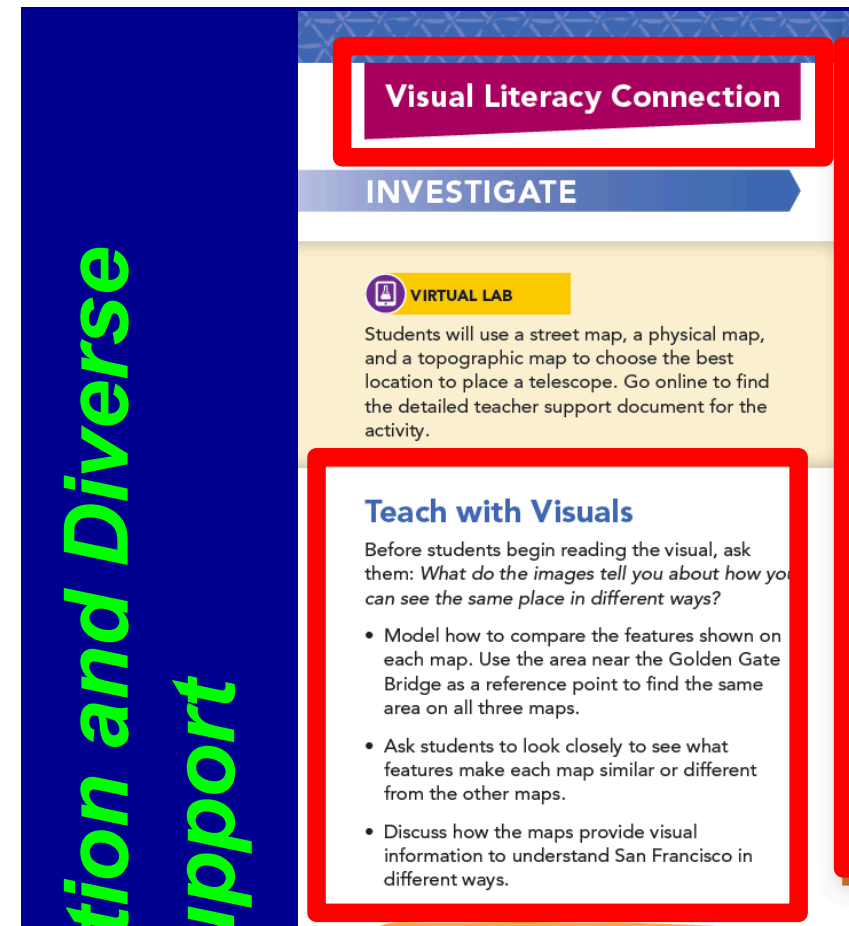

O. Focus on Mastery!

Analyzing and Interpreting Data Explain that maps are made for different purposes. Guide students to think about what professions
find each type of map the most useful.

- Environmental scientists would use topographic maps and data to und
features of a location

- City tour guides would use attractions maps to guide tourists from location to location.

- Have students consider professions that would use street maps of San Francisco. Ask them to explain why those professions would need maps.

160 Topic 4 Earth's Features

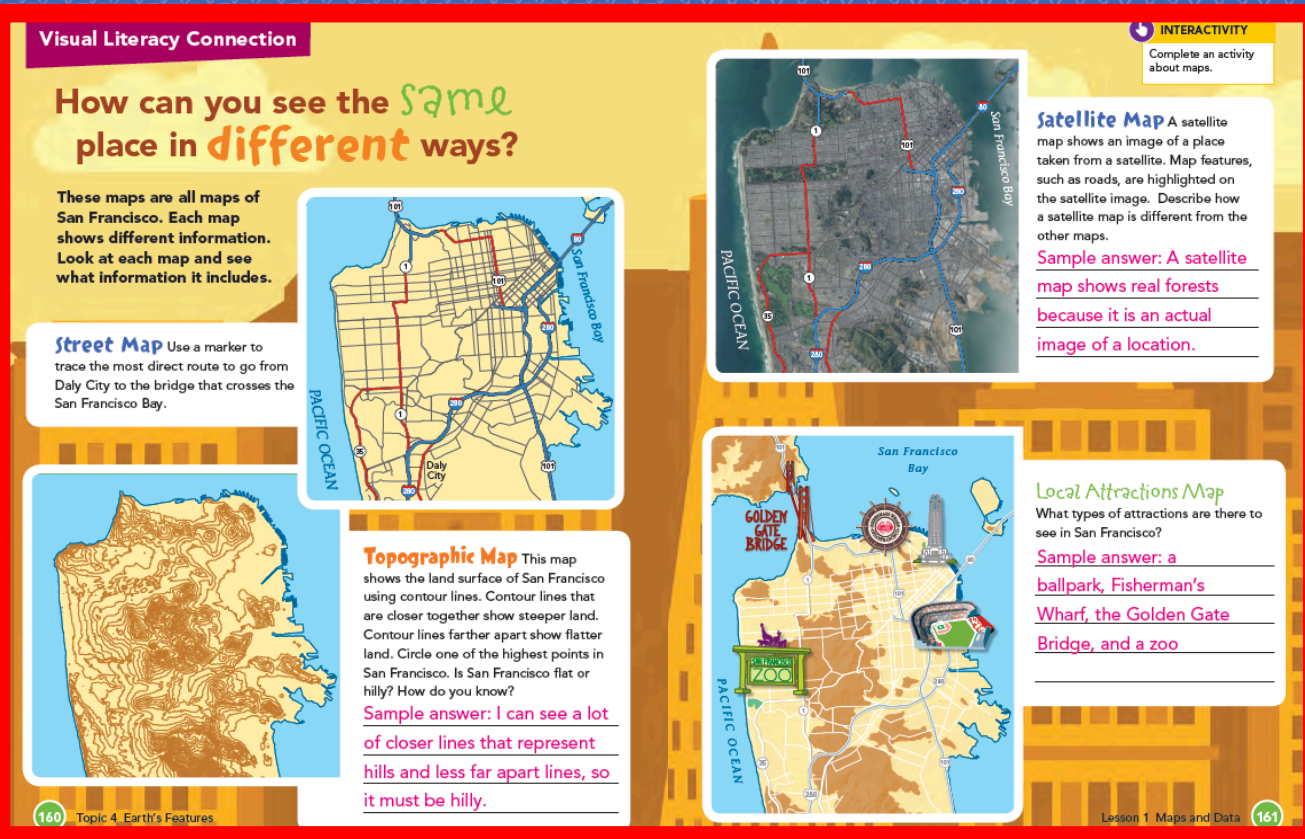

\section{Differentiated Instruction}

Support Struggling Students

Have students work with a partner to find the Pacific Ocean

on one of the maps. Then have them label the Pacific Ocean

on the topographic map. Be sure students understand that

although the three maps show different features of an are

Support Advanced Learners

Challenge advanced learners to research two different maps

of their hometown. Ask them to compare these maps and draw

conclusions about how certain types of maps serve different

purposes.

\section{ELD Support}

Speaking Use the text and images in the Visual Literacy Connection to help students practice their English vocabulary.

Entering Have students say the name of the city and state

ted in the visual.

Beginning Have students take turns telling whether San Francisco is flat or hilly.

Developing Have students use examples from the map to

Expanding Have students use details to prove whether San

Francisco is flat or hilly.

Bridging Have students identify whether each attraction is

located in a flat or hilly section of San Francisco.

\section{SYNTHESIZE}

\section{(5) InTERActivitr}

Have students complete the Synthesize Activity.

What it is Real world scenario-based

interactivities and engaging images

What it does Supports students in synthesizing and

applying what they've learned throughout the lesson

How to use it

- Students will click through the screens to explore the features of various types of maps.

\section{(․).) DOCUMENT}

Assign the Enrichment Activity to have students practice map skills by creating three different
types of maps of their neighborhood.

Scaffolded Questions Use the following questions to assess students' Depth of Knowledge levels of understanding. Identify Choose the map you would use to find your way from the airport to the Golden Gate your way from the airport to the Golden Gate
Bridge. Explain why this map would help you with this task. DOK1 (The street map will provide the names of streets for a rou
the Golden Gate Bridge.)

Summarize Relate the topographic map to the local attractions map. What information do you gain by using both together? DOK2 (The lopord faphic map shows the elevation of differen map shows the man-made features of the area. By looking at both maps together, I am able to understand which attractions are located on hills in San Francisco and which are closer to sea level.) Formulate Think about where you live. Which of these maps would be used most by the people in
your community? Explain your reasoning. DOK 3 your community? Explain your reasoning. DOK
(Answers will vary, but students will consider whether their community has many attractions or varying topography. Depending on the features of in the community.) 


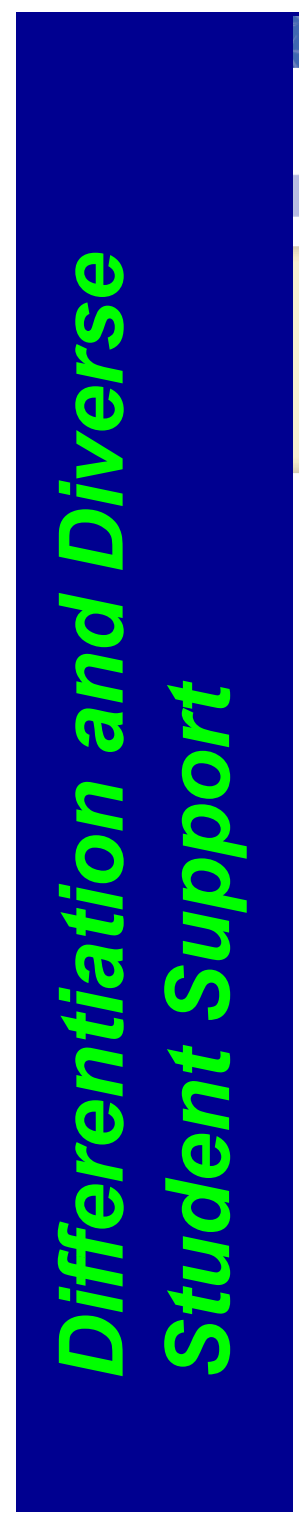

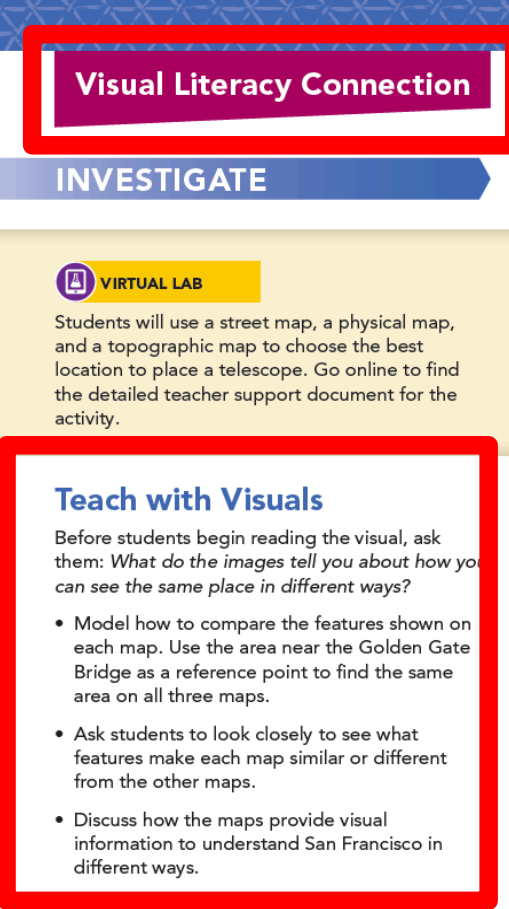

O. Focus on Mastery!

Analyzing and Interpreting Data Explain that maps are made for different purposes. Guide students to think about what protessions
find each type of map the most useful.

- Environmental scientists would use topographic maps and data to und wo
features of a location.

- City tour guides would use attractions maps to guide tourists from location to location.

- Have students consider professions that would use street maps of San Francisco. Ask them to explain why those protessions would need maps.

160 Topic 4 Earth's Features
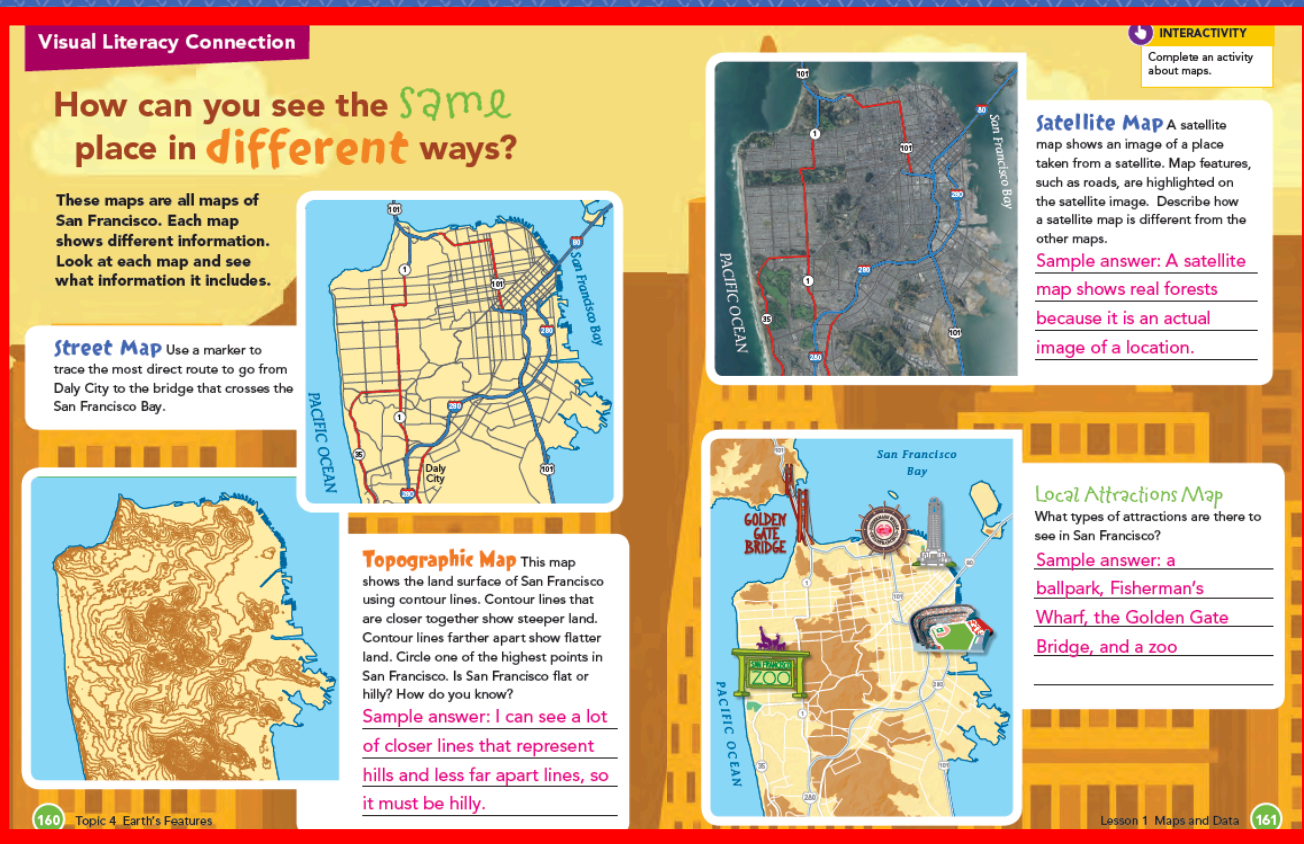

\section{Differentiated Instruction}

Support Struggling Students

Have students work with a partner to find the Pacific Ocean

on one of the maps. Then have them label the Pacific Ocean

on the topographic map. Be sure students understand tha

although the three maps show different features of an area,

Support Advanced Learners

Challenge advanced learners to research two different maps

of their hometown. Ask them to compare these maps and draw

conclusions about how certain types of maps serve different

purposes.

\section{ELD Support}

Speaking Use the text and images in the Visual Literacy Connection to help students practice their English vocabulary.

Entering Have students say the name of the city and state

esented in the visual.

Beginning Have students take turns telling whether San Francisco is flat or hilly.

Developing Have students use examples from the map to

Expanding Have students use details to prove whether San

Francisco is flat or hilly.

identify whether each attraction is

located in a flat or hilly section of San Francisco.

\section{SYNTHESIZE}

\section{(b) InTERActvitry}

Have students complete the Synthesize Activity.

What it is Real world scenario-based

interactivities and engaging images

What it does Supports students in synthesizing and

applying what they've learned throughout the lesson

How to use it

- Students will click through the screens to explore the features of various types of maps.

\section{(․).) DOCUMENT}

Assign the Enrichment Activity to have students practice map skills by creating three different
types of maps of their neighborhood.

Scaffolded Questions Use the following questions to assess students' Depth of Knowledge levels of understanding. Identify Choose the map you would use to find your way from the airport to the Golden Gate your way from the airport to the Golden Gate
Bridge. Explain why this map would help you with this task. DOK1 (The street map will provide the names of streets for a rout
the Golden Gate Bridge.)

Summarize Relate the topographic map to the local attractions map. What information do you gain by using both together? DOK2 (The lopograptic map shows the elevation of differen map shows the man-made features of the area. By looking at both maps together, I am able to understand which attractions are located on hills in San Francisco and which are closer to sea level.)

Formulate Think about where you live. Which of these maps would be used most by the people in
your community? Explain your reasoning. DOK 3 your community? Explain your reasoning. DOK
(Answers will vary, but students will consider whether their community has many attractions or varying topography. Depending on the features of in the community.) 


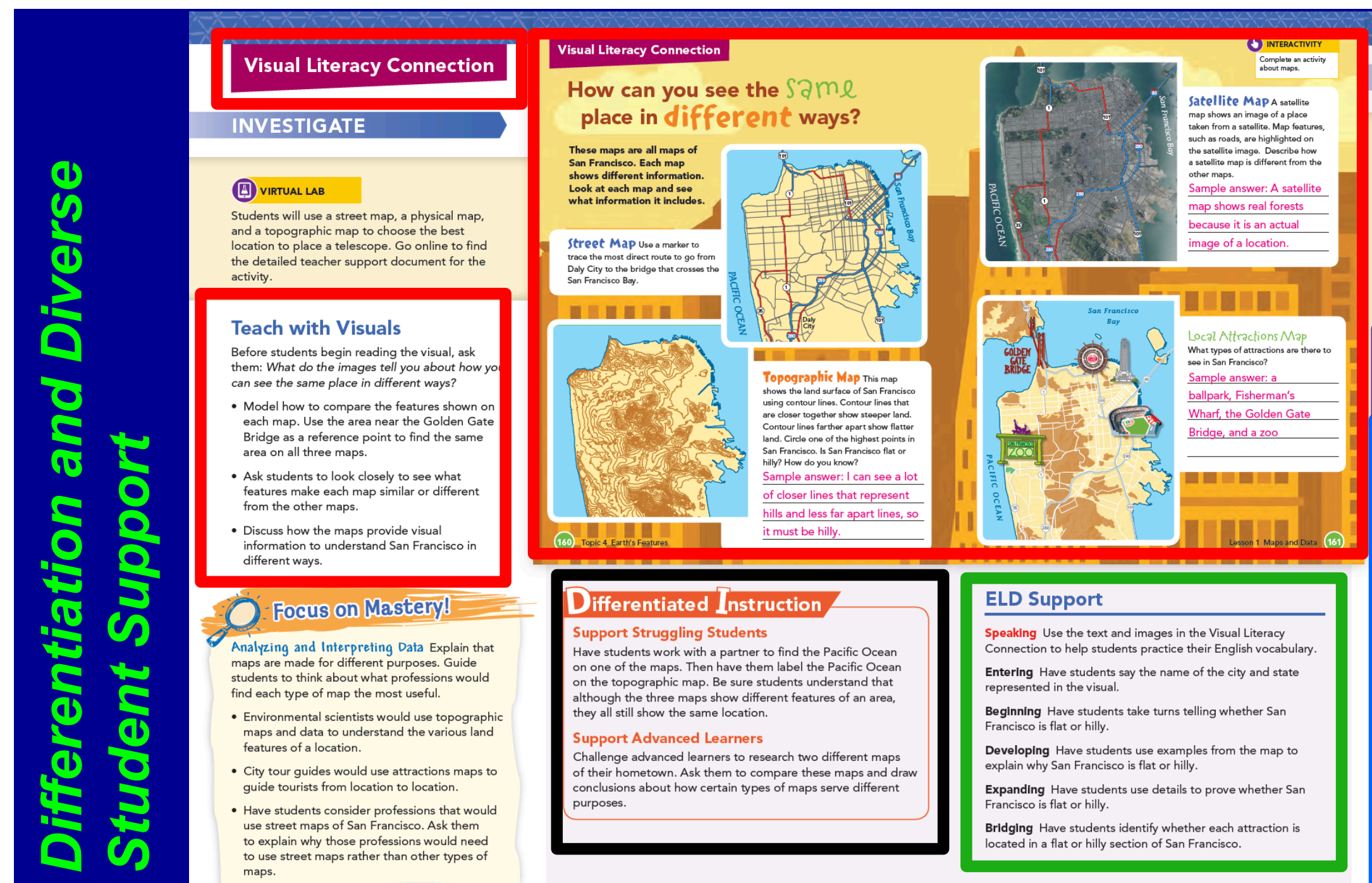

SYNTHESIZE

\section{(3) interactivity}

Have students complete the Synthesize Activity.

What it is Real world scenario-based

interactivities and engaging images

What it does Supports students in synthesizing and

applying what they've learned throughout the lesson

How to use it

- Students will click through the screens to explore the features of various types of maps.

\section{(i). DOCUMENT}

Assign the Enrichment Activity to have stude practice map skills by creating three differen

\section{Scaffolded Questions}

Use the following questions to assess students

Identify Choose the map you would use to find

your way from the airport to the Golden Gate

Bridge. Explain why this map would help you with
this task. Dok 1 (The street map will provide the

hames of streets for a route I can take to get to

the Golden Gate Bridge.)

Summarize Relate the topographic map to

the local attractions map. What information do

you gain by using both together? DOK2 (The

apegraphic map shows the elevation of different

map shows the man-made features of the area

By looking at both maps together, I am able to

understand which attractions are located on hills sin

San Francisco and which are closer to sea level.)

Formulate Think about where you live. Which of

these maps would be used most by the people in
your community? Explain your reasoning. DoK 3

(Answers will vary, but students will consider
(n)

whether their community has many attractions or

varying topography. Depending on the features of
the area, a road map may be most used by people

in the community.) 


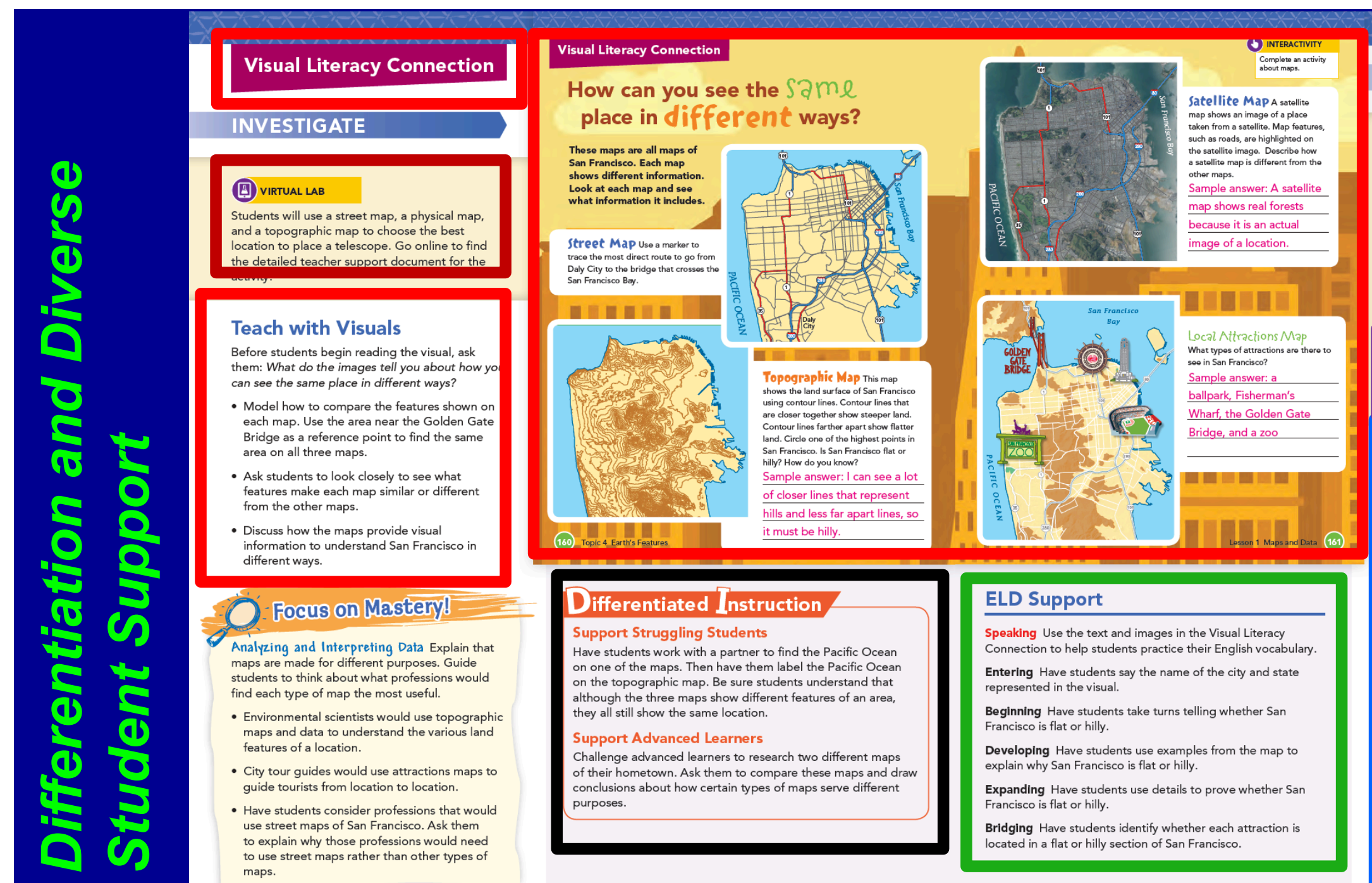

SYNTHESIZE

\section{(3) interactivitr}

Have students complete the Synthesize Activity.

What it is Real world scenario-based

interactivities and engaging images

What it does Supports students in synthesizing and

applying what they've learned throughout the lesson

How to use it

- Students will click through the screens to explore the features of various types of maps.

\section{(ㄱ)ㅇ DoCUMENT}

Assign the Enrichment Activity to have studen practice map skills by creating three different

Scaffolded Questions Use the following questions to assess students' evels of understanding. Identify Choose the map you would use to find your way from the airport to the Golden Gate Bridge. Explain why this map would help you with
this task. DOK1 (The street map will provide the hames of streets for a route I can take to get to the Golden Gate Bridge.)

Summarize Relate the topographic map to the local attractions map. What information do you gain by using both together? DOK2 (The opgraphic map shows the elevation of differen map shows the man-made features of the rae By looking at both maps together, I am able to understand which attractions are located on hills San Francisco and which are closer to sea level.)

Formulate Think about where you live. Which of these maps would be used most by the people in

your community? Explain your reasoning. DOK
(Answers will vary, but students will consider

(Answers will vary, but students will consider
whether their community has many attractions whether their community has many attractions or
varying topography. Depending on the features of the area, a road map may be most used by people in the community. 


\section{Keep in mind the "Five NGSS Innovations" when}

creating/adopting NGSS-designed Instructional Materials, and your classes will look like this....

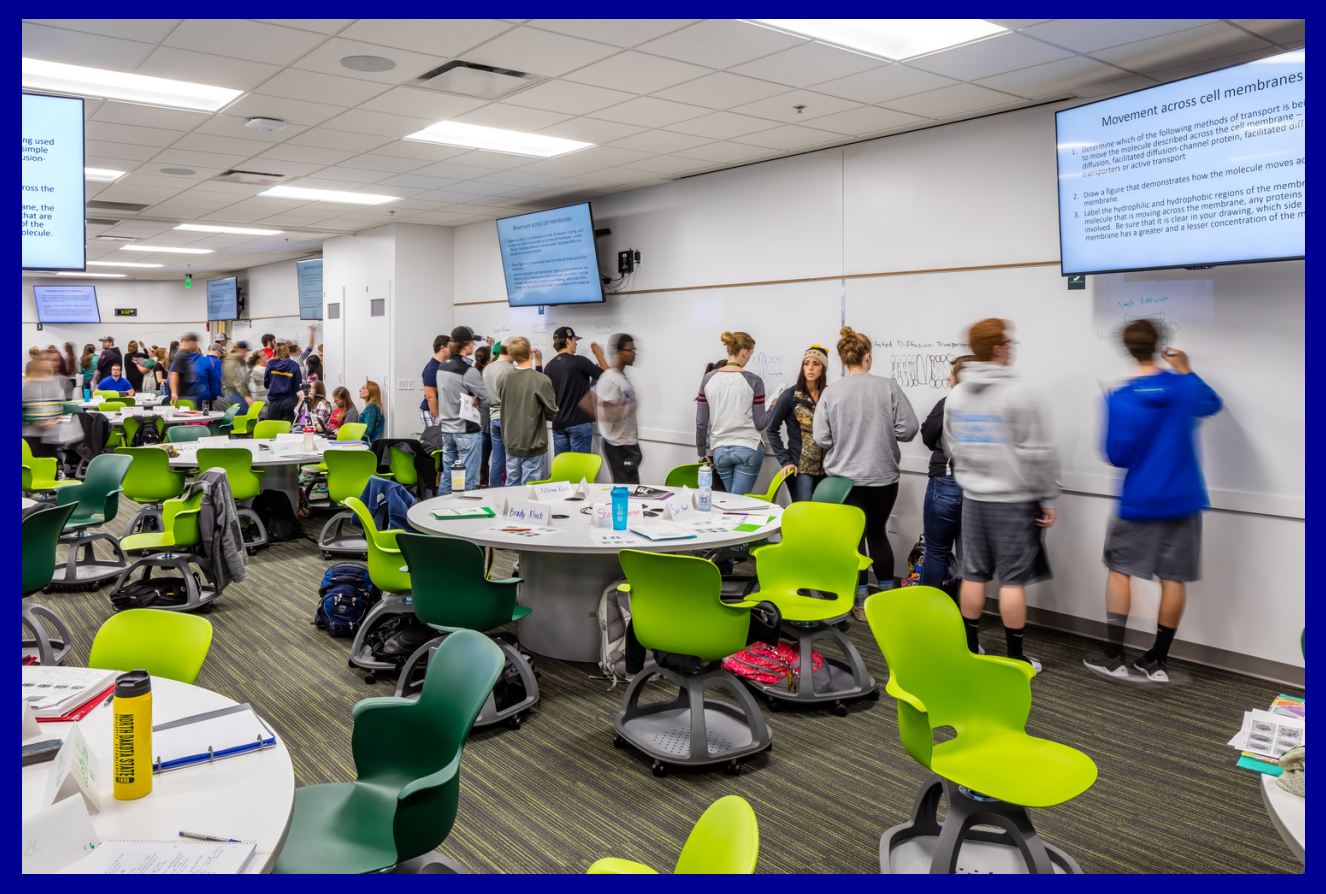




\section{Keep in mind the "Five NGSS Innovations" when}

creating/adopting NGSS-designed Instructional Materials, and your classes will look like

this....

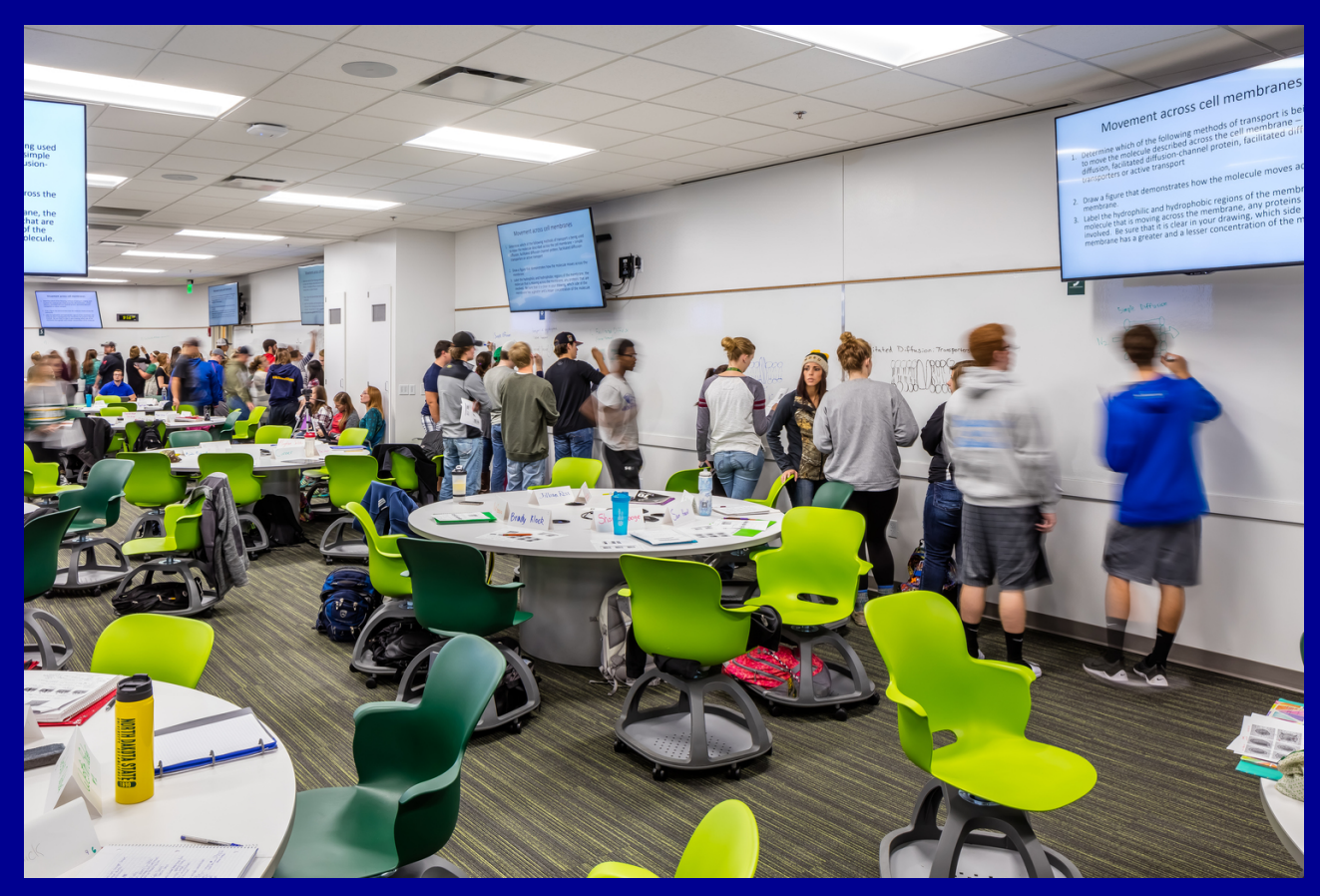

and not.....

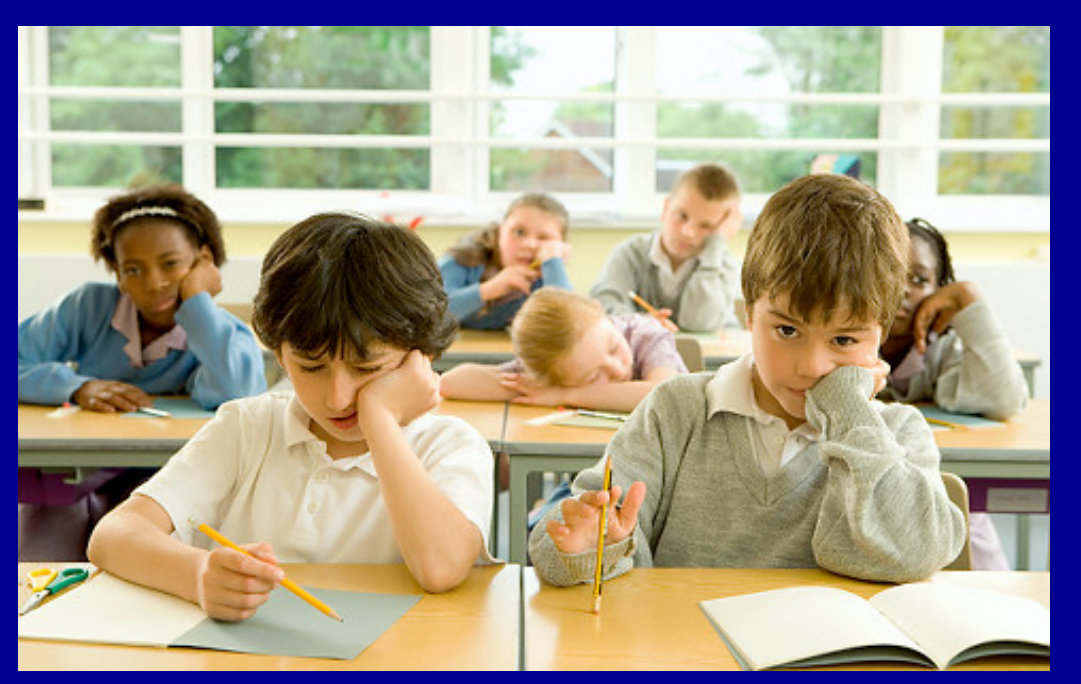

